Historic, Archive Document

Do not assume content reflects current scientific knowledge, policies, or practices. 



\section{CATALOGUE for 1919}

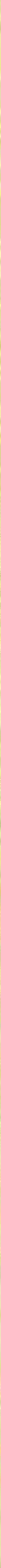




\section{\$1.00 "One Dollar" Collection}

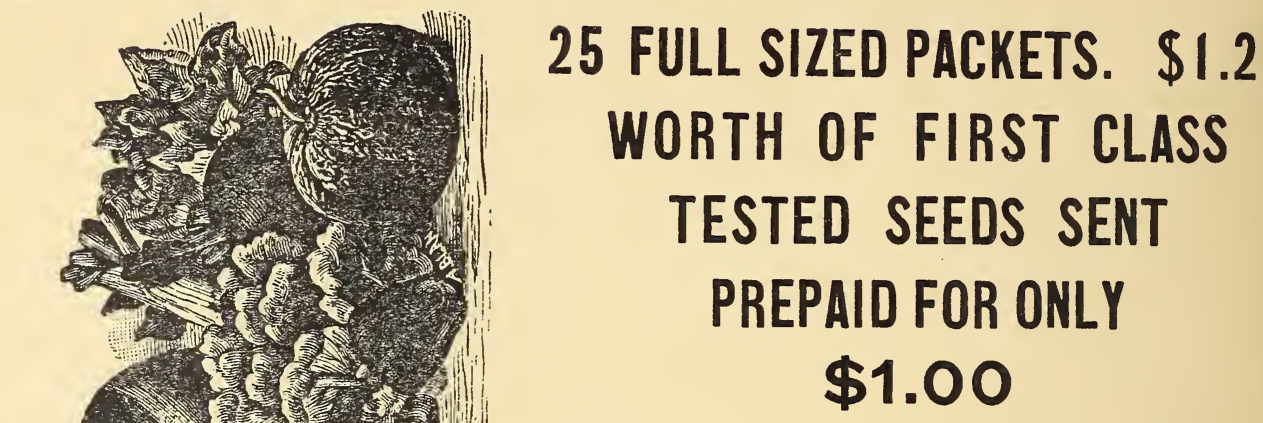

This collection is sufficient to plant a good sized garden and will keep your family, and even some of the neighbors, abundantly supplied with fresh vegetables all summer. We have selected the best varieties in all cases and we are sure the assortment will please you. Fresh Vegetables are essential in every happy home. Take advantage of this liberal offer and get $\$ 1.70$ worth of the very best vegetable seeds to be had for only $\$ 1.00$. Postpaid.

1 Beans-Golden Wax

2 Beans-Stringless Green Pod

3 Beet-Early

4 Cabbage

5 Carrot-Oxheart

6 Celery-Giant Pascal

7 Cucumber-Davis Perfect

8 Lettuce-Big Boston

9 Watermelon

10 Muskmelon-Rocky Ford

11 Muskmelon-Burrell Gem

12 Onion-Yellow Bermuda

13 Onion-Crystal White
14 Parsnip-Hollow Crown'd Sugar

15 Peas-Gradus

16 Parsley

17 Pepper-Sweet

18 Pumpkin-Small Sugar

19 Radish-French Breakfast

20 Radish-New Wht. Icicle

21 Radish-Early Scarlet Turnip

22 Squash-Hubbard

23 Squash-Early White Bush

24 Tomato-Earliana

25 Turnip

This collection is put up in advance and we can make no changes in it. No premium is allowed on this collection as it is a premium in itself. 


\section{THE HUTH SEED COMPANY "OLDEST SEED HOUSE IN THE SOUTH"}

On the same spot on Market Street for fifty-six years.

TO OUR CUSTOMERS:-

San Antonio, Texas

Perhaps never in the history of the seed industry have general conditions been so adverse to the successful production of seeds as in the past season. The importing of flower seed as well as garden seeds has been very uncertain. besides the excessive rains, followed by drought was most disastrous to growing seed stocks in America.

Our best efforts are exerted to hold our prices quoted in this catalogue as low as possible, but in some cases they become beyond our control. To prevent delay in filling orders, we always give our customers their money's worth

We thank our many customers of past years for their many favors and sincerly wish for all a successful year.

\section{Faithfully yours,}

THE HUTH SEED COMPANY

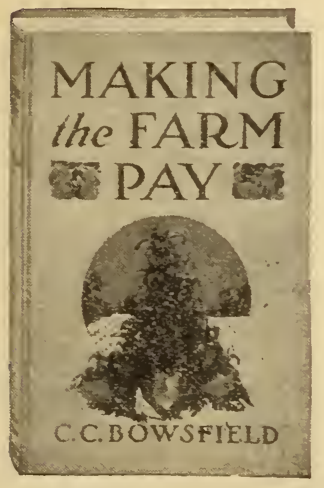

This is a reliable guid to poultry raising that thorol.ghly covers the subject of an expert. It is clear, practical and up-to-date The fifty-five chapters give full directions for the hatching and brooding of chickens, incubation, feeding and housing, increasing the egg supply, cure of
The most useful farm book ever published. It tells how to get the biggest returns from the soil and make farm life attractive and successful.

Farming opportunities, the marketing of produce, the raising of regetables, fruit and poultry, dairy products, and all phases of agriculture are discussed by an expert.

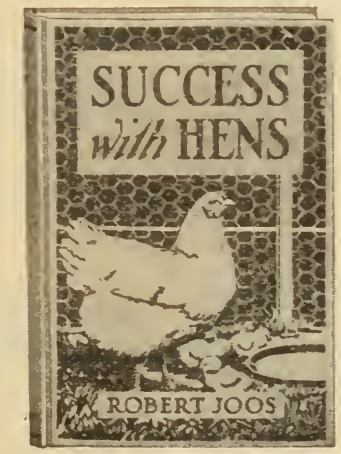

diseases, the marketing of cggs and fowls and everything pertaining to the care of $h: n s$.

Nothing is given but the best methods and only those which have been proved by the experience of successful poultry kcepers. The small and large. poultryman, the beginner and the experienced, will find this book indespensable. It will reduce losses and increase profits.

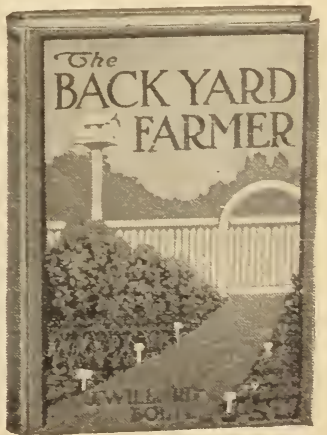


ABOUT GUARANTEE. Our seeds are all carefully selected and thoroughly tested as to vitality. However, as seeds of the best quality often fail through various causes beyond human control; therefore we give no warranty, expressed or implied, as to description, quality, productiveness, or any other matter, of any seeds, bulbs or plants we send out, and we will not be in any way responsible for the crop. If the purchaser does not accept the goods on these terms they are at once to be returned.

ABOUT PRICES. In consideration of the high quality of our seeds our prices are very low. All prices are subject to market fluctuations, but as a rule the prices of garden seeds hold good during the season.

\section{SEEDS NOW GO BY PARCEL POST}

Take advantage of this low rate of postage. The rates for the lower zones or up to any distance of 300 miles are very low and you can have your seeds delivered right to your door for less money than it would cost you to drive to town.

\section{REVISED PARCEL, POST LIST AND RULE CHANGES} ZONES

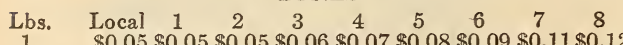

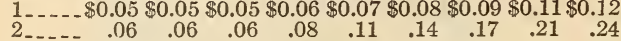

$\begin{array}{llllllllll}2 \ldots \ldots & .06 & .06 & .06 & .08 & .11 & .14 & .17 & .21 & .24 \\ 3 \ldots \ldots & .06 & .07 & .07 & .10 & .15 & .20 & .25 & .31 & .36 \\ 4\end{array}$

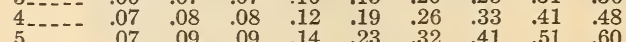

$\begin{array}{llllllllll}5 \ldots \ldots & .07 & .09 & .09 & .14 & .23 & .32 & .41 & .51 & .60 \\ 6 \ldots \ldots & .08 & .10 & .10 & .16 & .27 & .38 & .49 & .61 & .72\end{array}$

$\begin{array}{llllllllll}6 \ldots . . & .08 & .10 & .10 & .16 & .27 & .38 & .49 & .61 & .72 \\ 7 \ldots- & .08 & .11 & .11 & .18 & .31 & .44 & .57 & .71 & .84\end{array}$

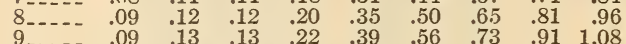

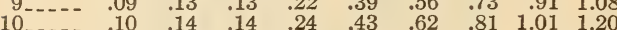

$\begin{array}{llllllllll}11 \ldots \ldots- & .10 & .14 & .14 & .24 & .43 & .62 & .81 & 1.01 & 1.20 \\ \ldots & .10 & .15 & .15 & .26 & .47 & .68 & .89 & 1.11 & 1.32\end{array}$

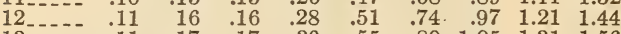

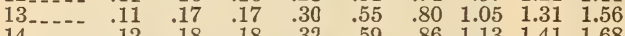

$\begin{array}{llllllllll}14 \ldots & .12 & .18 & .18 & .32 & .59 & .86 & 1.13 & 1.41 & 1.68 \\ 15 & .12 & .19 & .19 & .34 & .63 & .92 & 1.21 & 1.51 & 1.80\end{array}$

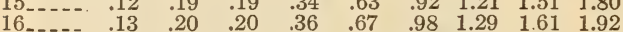

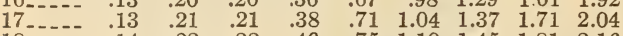

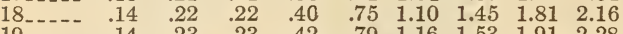

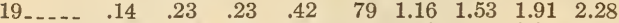

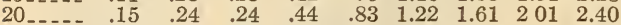

$\begin{array}{llllllllll}21 \ldots & .15 & .25 & .25 & .46 & .87 & 1.28 & 1.69 & 2.11 & 2.52\end{array}$

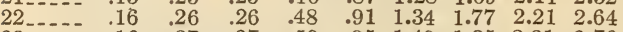

$\begin{array}{llllllllll}23 \ldots & .16 & .27 & .27 & .50 & .95 & 1.40 & 1.85 & 2.31 & 2.76\end{array}$

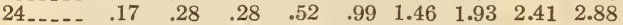

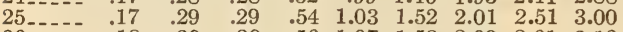

$\begin{array}{llllllllll}26 \ldots & .18 & .30 & .30 & .56 & 1.07 & 1.58 & 2.09 & 2.61 & 3.12 \\ 27 & . .18 & .31 & .31 & .58 & 1.11 & 1.64 & 2.17 & 2.71 & 3.24\end{array}$

$\begin{array}{llllllllll}28 & 19 & 32 & 32 & 60 & 1.15 & 1.70 & 2.25 & 2.81 & 3.36\end{array}$

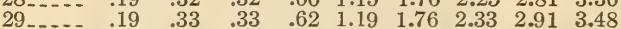

$\begin{array}{llllllllll}30 \ldots & .20 & .34 & .34 & .64 & 1.23 & 1.82 & 2.41 & 3.01 & 3.60\end{array}$

$\begin{array}{llllllllll}31 \ldots \ldots & .20 & .35 & .35 & .66 & 1.27 & 1.88 & 2.49 & 3.11 & 3.72\end{array}$

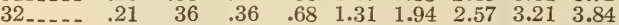

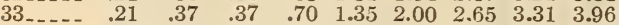

$\begin{array}{llllllllll}34 \ldots \ldots- & .22 & .38 & .38 & .72 & 1.39 & 2.06 & 2.73 & 3.41 & 4.08\end{array}$

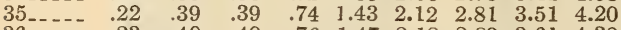

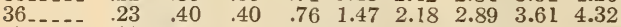

$\begin{array}{lllllllllll}37 & \ldots & .23 & .41 & .41 & .78 & 1.51 & 2.24 & 2.87 & 3.71 & 4.44\end{array}$

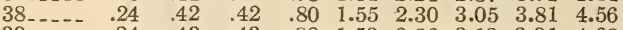

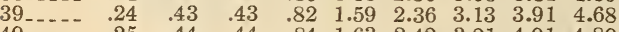

$\begin{array}{llllllllll}40 \ldots & .25 & .44 & .44 & .84 & 1.63 & 2.42 & 3.21 & 4.01 & 4.80\end{array}$

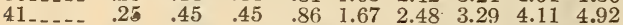

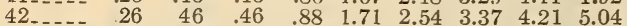

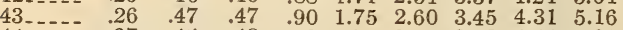

$\begin{array}{lllllllllll}44 \ldots & .27 & .48 & .48 & .92 & 1.79 & 2.66 & 3.53 & 4.41 & 5.28\end{array}$

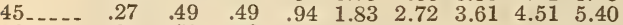

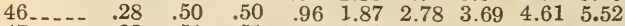

$\begin{array}{lllllllllll}47 & \ldots & .28 & .51 & .51 & .98 & 1.91 & 2.84 & 3.77 & 4.71 & 5.64\end{array}$

$\begin{array}{llllllllll}48 \ldots \ldots & .29 & .52 & .52 & 1.00 & 1.95 & 2.90 & 3.85 & 4.81 & 5.76 \\ 49 \ldots \ldots & .29 & .53 & .53 & 1.02 & 1.99 & 2.96 & 3.93 & 4.91 & 5.88\end{array}$

$\begin{array}{lllllllllll}50 \ldots . . & 30 & .54 & .54 & 1.04 & 2.03 & 3.02 & 4.01 & 5.01 & 6.00\end{array}$

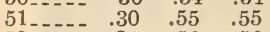

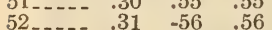

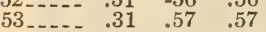

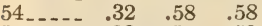

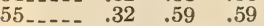

$\begin{array}{llll}56 \ldots \ldots & .33 & .60 & .60\end{array}$

$\begin{array}{llll}57 \ldots & .33 & .61 & .61\end{array}$

$\begin{array}{llll}58 \ldots & .34 & .62 & .62\end{array}$

$\begin{array}{llll}59 \ldots-\ldots & .34 & .63 & .63 \\ 60 \ldots & .35 & .64 & .64\end{array}$

$\begin{array}{llll}60 \ldots \ldots & .35 & .64 & .64 \\ 61 \ldots \ldots & .35 & .65 & .65\end{array}$

$\begin{array}{llll}62 \ldots \ldots & .35 & .65 & .65 \\ \ldots & .66 & .66\end{array}$

\section{PARCEL POST RATES}

Parcels weighing eight ounces or less are mailable at the rate of one cent. for each 2 ounce or fraction of an ounce, regardless of distance. Parcels weighing more than eight ounces are mailable at the pound rates shown in the accompanying table, a fraction of a pound being considered a ful! pound.

\section{HOW TO ORDER}

Fill out the order sheet enclosed herewith, writing your name and address very plainly.

\section{SEND CASH ALONG WITH ORDER.}

Remittances may be made by Money Order, Draft, Stamps or Currency. We accept any amount of stamps the same as cash. Be sure you register your letters if they contain cash. Money orders are the most economical and practical means of remitting.

ORDER EARLY! We will appreciate it if our customers will favor us with their kind orders as early as possible.

Send in your orders. You will be pleased with our service and well satisfied with our seeds.

Every time you order seeds or write to us, be sure and write your name, post office and State plainly. Hundreds of Orders are delayed every year because the Sender forgets to sign his name or give his post office address.

OUR TERMS with customers not having an account are strictly cash with order. We prefer not to send C. O. D. but if wanted by that method customers should enclose onefourth of the amount in remttance with Order. No plants or other perishable stock are sent C. O. D. 


\section{FREE PREMIUMS TAKE YOUR CHOICE}

A very pretty fern will be sent to you on request if accompanied by an order for $\$ 2.00$ worth of garden and flower seed. These seed must be ordered at the same time in packages and ounces, and we cannot give this premium when seed are ordered by the pound.

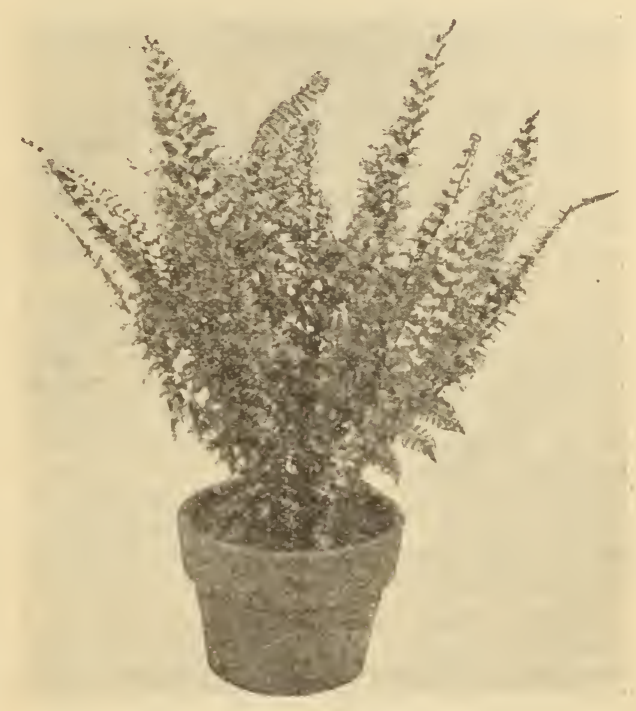

\section{ALAMO COOK BOOK}

This book of 100 pages contains many recipes of Mexican dishes.

The information on pickling alone is worth a great deal to the housewife.

Beverages selected by experienced parties are very appropriate for special occasions as birthdays, Christmas, etc. $l$.

In fact the receipts are too numerous to mention here, with the fact that they were made by housewives here in San Antonio.

This nicely bound book will be sent free with an order for $\$ 2.00$ worth of garden and flower seed in packages and ounces or $\$ 10.00$ worth of field seed.

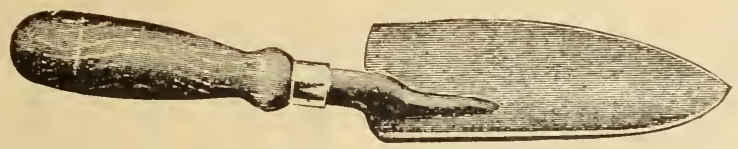

STEEL TROWEL

Here is a free premium that can be used in every garden. The fact that this trowel is not rivited makes it very durable and lasts for years. On request this handy tool will be shipped with an order for $\$ 1.75$ worth of garden and flower seed in packages or ounces only.

\section{PAIR OF GARDENER'S GLOVES}

This pair of gloves will be sent free with an order of $\$ 1.50$ worth of garden or flower seeds in packages or ounces.

These canvas gloves are as handy in the garden as in the field. Please mention with order if you desire this premium. 
Directions for Planting.

The directions given here are for Texas. If applied to localities north of here the time of planting will not be quite as early in the Spring and earlier in the Fall. For instance the directions given for January will answer for February in the northern part of this State and Mississippi and the southern part of Alabama. In autumn directions for September can be followed in August.

VEGETABLE GARDEN.--Sow Spinach' Mustard, Carrots, Beets, Turnips, Leeks, Radish, Ruta Baga, Lettuce, Endive, Cabbage, Broccoli, Kohlrabi and early Cauliflower. As the weather is very unstable, it is best to sow in a frame and protect young plants during severe cold weather.

Cress, Chervil, Parsely, Celery and Carrots should be sown. Sow in hot-bed Eggplants, Peppers and Tomatoes. Plant all varieties of Garden Peas, for general crop. Plant Onion Sets, Chives, Shallots; also set out plants. Transplant Onions. Sow Sweet and Medicinal Herbs.

Cucumbers can be planted for forcing. It is best to plant the seeds in dirt bands first, and when the third leaf is developed transplant into the hot-bed.

FIELD.-Plant early varieties of Irish potatoes.

Asparagus Roots, Artichoke Plants and Rhubarb and Horseradish Roots should be set out, also Red Rust-Proof Oats, Seed Rye, Barley, Wheat, Speltz, Vetches, Buckwheat, all varieties of Clover, Drawf Essex Rape, Kentucky Blue, Red Top, Johnson, Tall Meadow Oat, Meadow Fescue, Guinea and Orchard Grasses, Timothy, all varieties of Millet, Giant Beggar Weed, Lespedeza or Japan Clover and Bermuda Grass should be sown.

ORCHARD.-Fruit trees of all kinds should be planted, as well as Citrus Trifoliata and Sour Orange seeds.

January and February are the best months to set out fruit trees.

FLOWER GARDEN.-Continue to sow flower seeds during this month for spring and early summer blooming. The best varieties are Verbena, Phlox, Petunia, Summer Chrysanthemum, Scarlet Sage, Hollyhock, Sweet Alyssum, Snapdragon, Aster, Columbine, Daisy, Bell Flower, Sweet Sultan, Correopsis, Sweet William, Chinese and Carnation Pinks, Larkspur, California Poppy, Heliotrope, Candytuft, Lobelia, Monkey Flower, Sweet Mignonette, Flowering Sweet Peas and Pansies, also Japan and Tiger Lillies and Narcissus bulbs for late flowering. In a cold frame sow at the end of the month Balsams (Lady Slippers), Zinnia, Amaranthus, Cockscomb, Rosa Montana, Evening Glory and Nasturtium, and in the greenhouse in pots Begonia Rex, Begonia Tuberosa and Cyclamen. Plant Gladiolus, Hyacinths,

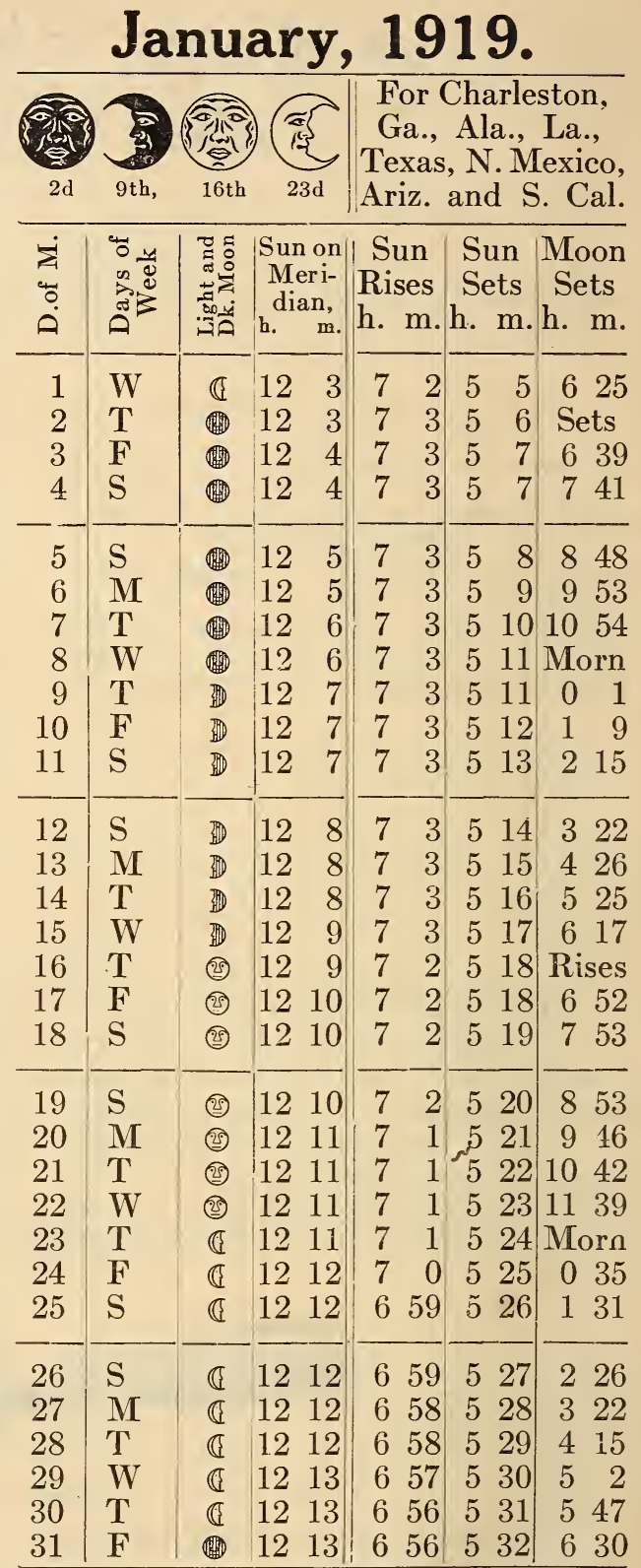

Tulips, all varieties of Narcissus, Anemones, Ranunculus, Chinese Sacred Lilies, Oxalis or Buttercup, all varieties of Calla Lilies, Scilla Peruviana, Tuberoses, all varieties of Japan Lilies, Spanish Iris, and Freesia bulbs out of doors in sheltered places for early blooming, Set out Roses and flowering ornamental shrubs. Fall annuals named in this catalogue can be planted this month. 


\section{February, 1919.}

\begin{tabular}{|c|c|c|c|c|c|c|}
\hline & & & $\frac{\sqrt{65}}{15}$ & $\begin{array}{c}\text { For } \\
\text { Ga., } \\
\text { Texas, } \\
\text { Ariz. }\end{array}$ & $\begin{array}{l}\text { Charle } \\
\text { Ala., } \\
\text { N. I } \\
\text { and }\end{array}$ & $\begin{array}{l}\text { ston, } \\
\text { La., } \\
\text { Iexico } \\
\text { S. Cal }\end{array}$ \\
\hline A & 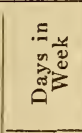 & 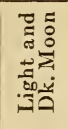 & $\begin{array}{l}\mathrm{h} . \mathrm{m} . \\
\text { Siun on } \\
\text { Mleri- } \\
\text { dian. }\end{array}$ & $\mid \begin{array}{c}\text { Sun } \\
\text { Rises } \\
\text { h. m. }\end{array}$ & $\begin{array}{l}\text { Sun } \\
\text { Sets } \\
\text { h. m. }\end{array}$ & $\begin{array}{l}\text { Moon } \\
\text { Rises } \\
\text { h. m. }\end{array}$ \\
\hline 1 & S & (1) & 1213 & 655 & $\begin{array}{lll}5 & 32\end{array}$ & Sets \\
\hline $\begin{array}{l}2 \\
3 \\
4 \\
5 \\
6 \\
7 \\
8\end{array}$ & $\begin{array}{l}\mathrm{S} \\
\mathrm{M} \\
\mathrm{T} \\
\mathrm{W} \\
\mathrm{T} \\
\mathrm{F} \\
\mathrm{S}\end{array}$ & (i) & $\begin{array}{ll}12 & 13 \\
12 & 13 \\
12 & 14 \\
12 & 14 \\
12 & 14 \\
12 & 14 \\
12 & 14\end{array}$ & $\begin{array}{ll}6 & 54 \\
6 & 54 \\
6 & 53 \\
6 & 52 \\
6 & 52 \\
6 & 51 \\
6 & 50\end{array}$ & $\begin{array}{ll}5 & 34 \\
5 & 34 \\
5 & 35 \\
5 & 36 \\
5 & 37 \\
5 & 38 \\
5 & 39\end{array}$ & $\begin{array}{rr}7 & 41 \\
8 & 44 \\
6 & 52 \\
11 & 1 \\
\text { Mor } & 1 \\
0 & 8 \\
1 & 15\end{array}$ \\
\hline $\begin{array}{r}9 \\
10 \\
11 \\
12 \\
13 \\
14 \\
15\end{array}$ & $\begin{array}{l}\mathrm{S} \\
\mathrm{M} \\
\mathrm{T} \\
\mathrm{W} \\
\mathrm{T} \\
\mathrm{F} \\
\mathrm{S}\end{array}$ & $\begin{array}{l}\text { D } \\
\text { i } \\
\text { i } \\
\text { (1) } \\
\text { (2) }\end{array}$ & $\begin{array}{ll}12 & 14 \\
12 & 14 \\
12 & 14 \\
12 & 14 \\
12 & 14 \\
12 & 14 \\
12 & 14\end{array}$ & $\left|\begin{array}{ll}6 & 49 \\
6 & 48 \\
6 & 47 \\
6 & 46 \\
6 & 46 \\
6 & 45 \\
6 & 44\end{array}\right|$ & $\begin{array}{ll}5 & 40 \\
5 & 41 \\
5 & 42 \\
5 & 43 \\
5 & 44 \\
5 & 44 \\
5 & 45\end{array}$ & $\begin{array}{cc}2 & 18 \\
3 & 18 \\
4 & 10 \\
4 & 58 \\
5 & 39 \\
\text { Rises } \\
6 & 40\end{array}$ \\
\hline $\begin{array}{l}16 \\
17 \\
18 \\
19 \\
20 \\
21 \\
22\end{array}$ & $\begin{array}{l}\text { S } \\
M \\
T \\
\text { W } \\
T \\
F \\
\text { S }\end{array}$ & $\begin{array}{l}\text { (2) } \\
\text { (3) } \\
\text { (3) } \\
\text { (3) } \\
\text { (3) } \\
\text { (1) }\end{array}$ & $\begin{array}{ll}12 & 14 \\
12 & 14 \\
12 & 14 \\
12 & 14 \\
12 & 13 \\
12 & 13 \\
12 & 13\end{array}$ & $\begin{array}{ll}6 & 43 \\
6 & 42 \\
6 & 41 \\
6 & 40 \\
6 & 39 \\
6 & 38 \\
6 & 36\end{array}$ & $\begin{array}{ll}5 & 46 \\
5 & 47 \\
5 & 48 \\
5 & 49 \\
5 & 50 \\
5 & 50 \\
5 & 51\end{array}$ & $\begin{array}{rr}7 & 34 \\
8 & 31 \\
9 & 29 \\
10 & 23 \\
11 & 20 \\
\text { 11 } & \\
12 & 14\end{array}$ \\
\hline $\begin{array}{l}23 \\
24 \\
25 \\
26 \\
27 \\
28\end{array}$ & $\begin{array}{l}\mathrm{S} \\
\mathrm{M} \\
\mathrm{T} \\
\mathrm{W} \\
\mathrm{T} \\
\mathrm{F}\end{array}$ & $\begin{array}{l}\mathbb{a} \\
\mathbb{a} \\
\mathbb{a} \\
\mathbb{a} \\
\mathbb{a} \\
\mathbb{a}\end{array}$ & $\begin{array}{ll}12 & 13 \\
12 & 13 \\
12 & 13 \\
12 & 13 \\
12 & 12 \\
12 & 12\end{array}$ & $\mid \begin{array}{ll}6 & 35 \\
6 & 34 \\
6 & 33 \\
6 & 32 \\
6 & 31 \\
6 & 30\end{array}$ & $\begin{array}{ll}5 & 52 \\
5 & 53 \\
5 & 54 \\
5 & 55 \\
5 & 56 \\
5 & 56\end{array}$ & $\begin{array}{rr}1 & 9 \\
2 & 2 \\
2 & 52 \\
3 & 38 \\
4 & 21 \\
5 & 1\end{array}$ \\
\hline
\end{tabular}

When ordering seed with PREMIUM, be sure to follow instructions on page 3 .

For Roses, Ferns. and Climbing Plants, see Pages 80 and 81.
VEGETABLE GARDEN.-All winter vegetables can be sown this month, such as Spinach, Mustard, Carrots, Beets, Parsnips, Leeks, Radishes, Swiss Chard, Kohlrabi, Lettuce. Cabbage and Early Cauliflower. If the weather is favorable and the month of April dry, the latter will succeed well.

Cauliflower, Cabbage, Lettuce and Kohlrabi should be transplanted, Shallots divided and set out again, also sow Sorrel, Chervil, Parsley, Cress and Celery for seasoning.

All varieties of Peas can be planted.

Sweet and Medicinal Herbs should be planted.

Plant Artichoke, Rhubarb and Asparagus seed and roots. Set out Horseradish roots.

Hot beds on account of the changeable weather during this month, require a good deal of attention.

Begin to plant Bush Beans as soon as the weather permits; also Cucumbers, Squash, and Melons, as they often succeed if protected by small boxes or dirt bands, covered with glass. Set out Onion Sets, Chives and Shallots.

At the end of this month Early Corn can be planted.

For market use Adams Extra Early, Stowells Evergreen, Golden Bantam, Country Gentleman, White 90 day and other early varieties.

FIELD. - February is the best month to plant a general crop of all varieties of potatoes, as, on an average, they will succeed better if planted during this month. Plant Jerusalem Artichokes.

All of the Grasses, Clovers and Field Seeds mentioned for January can be sown this month, as well as Bermuda Grass. Sorghum, Milo Maize, Feterita, Egyptian Wheat and Kaffir Corn can also be planted.

Mangel Wurzel and Sugar Beets as well as Carrots should be sown for stock food. Sweet Potatoes can be put in a bed for sprouting, so as to have early slips.

Sow all varieties of Field Corn.

ORCHARD.-Plant fruit trees of all kinds. Pecan nuts may be planted to raise trees from

FLOWER GARDEN.-Sow flower seed for late spring and early summer, such as Zinnia and Balsains (Lady Slippers), in frame; different varieties of Gomphrenas, etc.

Set out Roses and ornamental Shrubs. Plant Gladiolus and Tuberose bulbs, Sweet Alyssum, Candystuft, Snapdragon, Pansy, Aster, Chinese Pinks, Daises for late blooming Lobelia, Reseda, Sweet Sultan, Phlox, Verbena, Cosmos, Correopsis, Sunflower, Cobaea, Scandens, Rosa Montana, Aristolochia Elegans, Tagetes, Salvia and Vinca. Plant all bulbous roots as directed for last month.

Follow same directions as given for January for Fall annual plants. 
VEGETABLE GARDEN.-Sow Beets, Radishes, early Cabbage, Kohlrabi, all varieties of Lettuce, Spinach, Mustard, Carrots, Swiss Chard, Leeks, Celery for cutting, Parsley, Cress and Chervil,

Plant all varieties of Bush and Pole Beans, but for Lima Beans it is better to wait until the end of the month, as they rot easily when the ground is not warm enough or too wet.

Squash, Cucumbers, Melons and Okra can be planted. The remark in regard to Lima Beans holds good also for Okra. Early varieties of Peas can still be planted. Set out Tomatoes, Eggplants and Peppers in the open ground and sow seed for latter crop. Plant Sweet Corn.

Beans are hard to keep in this climate; the Tepary, Lima and White and Red Kidney can be planted for shelling purposes.

Set out Onion Sets, Chives, and Shallots

FIELD.-Sow Sorghum, Kaffir Corn, Milo Maize, Feterita, Egyptian Wheat, all varieties of Millet, Texas Ribbon Cane and Teosinte for green feed. Sow Bermuda, Lespedeza and all varieties of Clover and Grass seed for hay and grazing.

Plant Irish and Sweet Potatoes, all varieties of Field and Broom Corn. Plant Sorghum, also all varieties of Cow Peas, Canada Field Peas, Soja and Velvet Beans. Plant Jerusalem Artichokes.

ORCHARD.-Fruit trees may be planted the early part of this month, or later on when the season is somewhat retarded.

FLOWER GARDEN.-Sow Balsams (Lady Slippers), Zinnia, Amaranthus, Dahlia, Cockscomb, Cosmos, Portulacca and Sunflower. Set out Chrysanthemums for fall blooming.

For Fall annual plants see directions for January.

Use Hammond's Slug Shot for all LeafEating Insects on all Vegetable Plants.

\section{March, 1919.}

\begin{tabular}{|c|c|c|c|c|c|c|}
\hline$E$ & 8 & & & $\mid \begin{array}{c}\text { For } \\
\text { Ga., } \\
\text { Texas } \\
\text { Ariz. }\end{array}$ & $\begin{array}{l}\text { Charle } \\
\text { Ala., } \\
\text { N. I } \\
\text { and }\end{array}$ & $\begin{array}{l}\text { eston, } \\
\text { La., } \\
\text { Mexico } \\
\text {. Cal. C }\end{array}$ \\
\hline $\begin{array}{l}\overrightarrow{\mathrm{z}} \\
\dot{\overrightarrow{0}} \\
\dot{\theta}\end{array}$ & 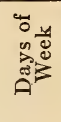 & 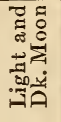 & $\begin{array}{l}\text { Sun on } \\
\text { Meri- } \\
\text { dian. } \\
\text { h. } \quad \text { m. }\end{array}$ & $\begin{array}{l}\text { Sun } \\
\text { Rises } \\
\text { h. m. }\end{array}$ & $\begin{array}{l}\text { Sun } \\
\text { Sets } \\
\text { h. m. }\end{array}$ & $\begin{array}{l}\text { Moon } \\
\text { Rises } \\
\text { h. m. }\end{array}$ \\
\hline 1 & $\mathrm{~S}$ & $\mathbb{1}$ & 1212 & 628 & 557 & 537 \\
\hline $\begin{array}{l}2 \\
3 \\
4 \\
5 \\
6 \\
7 \\
8\end{array}$ & $\begin{array}{l}\mathrm{S} \\
\mathrm{M} \\
\mathrm{T} \\
\mathrm{W} \\
\mathrm{T} \\
\mathrm{F} \\
\mathrm{S}\end{array}$ & 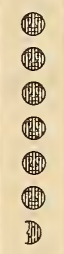 & $\begin{array}{ll}12 & 12 \\
12 & 12 \\
12 & 11 \\
12 & 11 \\
12 & 11 \\
12 & 11 \\
12 & 11\end{array}$ & $\begin{array}{ll}6 & 27 \\
6 & 26 \\
6 & 25 \\
6 & 24 \\
6 & 22 \\
6 & 21 \\
6 & 20\end{array}$ & $\begin{array}{rr}5 & 58 \\
5 & 59 \\
6 & 0 \\
6 & 0 \\
6 & 1 \\
6 & 2 \\
6 & 2\end{array}$ & \begin{tabular}{|cc} 
Sets \\
7 & 35 \\
8 & 45 \\
9 & 56 \\
11 & 5 \\
Morn \\
0 & 11
\end{tabular} \\
\hline $\begin{array}{r}9 \\
10 \\
11 \\
12 \\
13 \\
14 \\
15\end{array}$ & $\begin{array}{l}M \\
T \\
W \\
T \\
F \\
S\end{array}$ & 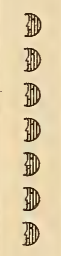 & $\begin{array}{rr}12 & 10 \\
12 & 10 \\
12 & 10 \\
12 & 10 \\
12 & 9 \\
12 & 9 \\
12 & 9\end{array}$ & $\begin{array}{ll}6 & 19 \\
6 & 17 \\
6 & 16 \\
6 & 15 \\
6 & 14 \\
6 & 12 \\
6 & 11\end{array}$ & $\begin{array}{ll}6 & 3 \\
6 & 4 \\
6 & 5 \\
6 & 5 \\
6 & 6 \\
6 & 7 \\
6 & 8\end{array}$ & $\begin{array}{rr}1 & 13 \\
2 & 7 \\
2 & 55 \\
3 & 39 \\
4 & 16 \\
4 & 49 \\
5 & 20\end{array}$ \\
\hline $\begin{array}{l}17 \\
18 \\
19\end{array}$ & $\begin{array}{l}\mathrm{M} \\
\mathrm{T} \\
\mathrm{W} \\
\mathrm{T} \\
\mathrm{F} \\
\mathrm{S}\end{array}$ & $\begin{array}{l}\text { (2) } \\
\text { (2) } \\
\text { (2) } \\
\text { (2) } \\
\text { (2) } \\
\text { (2) } \\
\text { (2) }\end{array}$ & $\begin{array}{ll}12 & 8 \\
12 & 8 \\
12 & 8 \\
12 & 8 \\
12 & 7 \\
12 & 7 \\
12 & 7\end{array}$ & $\begin{array}{rr}6 & 10 \\
6 & 8 \\
6 & 7 \\
6 & 6 \\
6 & 4 \\
6 & 3 \\
6 & 2\end{array}$ & $\begin{array}{rr}6 & 8 \\
6 & 9 \\
6 & 10 \\
6 & 10 \\
6 & 11 \\
6 & 12 \\
6 & 13\end{array}$ & \begin{tabular}{rr}
\multicolumn{2}{r}{ Rises } \\
7 & 18 \\
8 & 15 \\
9 & 11 \\
10 & 6 \\
11 & 0 \\
11 & 53
\end{tabular} \\
\hline $\begin{array}{l}26 \\
27 \\
28 \\
29\end{array}$ & $\begin{array}{l}1 \\
1 \\
\text { T } \\
\text { T } \\
\text { T }\end{array}$ & $\begin{array}{l}\text { (2) } \\
\text { (15 } \\
\text { ब15 } \\
\text { ब1 } \\
\text { (8) } \\
\text { ब1 } \\
\text { ब18 }\end{array}$ & $\begin{array}{ll}12 & 6 \\
12 & 6 \\
12 & 6 \\
12 & 5 \\
12 & 5 \\
12 & 5 \\
12 & 5\end{array}$ & $\begin{array}{lr}6 & 1 \\
5 & 59 \\
5 & 58 \\
5 & 56 \\
5 & 55 \\
5 & 54 \\
5 & 53\end{array}$ & $\begin{array}{ll}6 & 13 \\
6 & 14 \\
6 & 15 \\
6 & 16 \\
6 & 16 \\
6 & 17 \\
6 & 18\end{array}$ & $\begin{array}{rr}\text { Morn } \\
0 & 43 \\
1 & 29 \\
2 & 13 \\
2 & 52 \\
3 & 31 \\
4 & 5\end{array}$ \\
\hline & & (1) & $\begin{array}{ll}12 & 4 \\
12 & 4\end{array}$ & $\begin{array}{ll}5 & 51 \\
5 & 50\end{array}$ & $\begin{array}{ll}6 & 18 \\
6 & 19\end{array}$ & $\begin{array}{ll}4 & 42 \\
5 & 23\end{array}$ \\
\hline
\end{tabular}

\section{"HAMMOND'S SLUG SHOT"}

\section{Used from Ocean to Ocean}

A light composite, fine powder, easily distributed either by duster, bellows, or in water by spraying. Thoroughly reliable in killing Currant Worms, Potato Bugs, Cabbage Worms, Lice, Slugs, Sow Bugs, etc., and is also strongly impregnated with fungicides. Put up in Popular Packages at Popular Prices. See Page 106. 
VEGETABLE GARDEN.-Sow Bush, Pole and Lima Beans, Sweet Corn, Cucumbers, Squash, Melons and Okra, Beets, Carrots, Swiss Chard, Radishes, Lettuce, Mustard, Endive, Cress, Parsley, Chervil and Celery for cutting.

Set out Onion Sets, Chives and Shallots.

Sow Tomatoes, Eggplants and Peppers.

Early Cabbages may be successfully sown. Kohlrabi can be sown, but it is best to sow thinly in drills a foot apart, and thin out to four inches in the rows, instead of transplanting. Towards the end of this month a sowing of the late Cauliflower can be made. A good plan is to sow seed in boxes elevated two or three feet above the ground, as it will keep the Cabbage $\mathrm{fly}$ off. The plants should be looked over daily and all green cabbage worms and other vermin removed.

FIELD.-Dig Irish Potatoes planted early, and after well preparing the ground, plant Corn, Beans, Squash, etc.

Sow Cashaw and field Pumpkins.

Sow all varieties of Grass mentioned for March, especially Rhodes Grass.

ORCHARD.-Little is to be done during this month, except perhaps, if the weather is favorable, budding Orange trees on Trifoliata or Sour stocks: keep young trees clean of weeds, and during a dry spell water those which were lately transplanted.

FLOWER GARDEN.--Sow Balsams (Lady Slippers), Gomphrenas and Amaranthus, Celosia, Vinca Rosea. Plant Colens and other foliage plants, Dahlias and Chrysanthemums, Sun flower, Gladiolas and Tuberose bulbs.

Plant all annuals described in this catalogue.

IT'S MUCH BETTER TO BE SURE THAN

SORRY

PLANT HUTH'S TESTED SEEDS.

\section{April, 1919.}

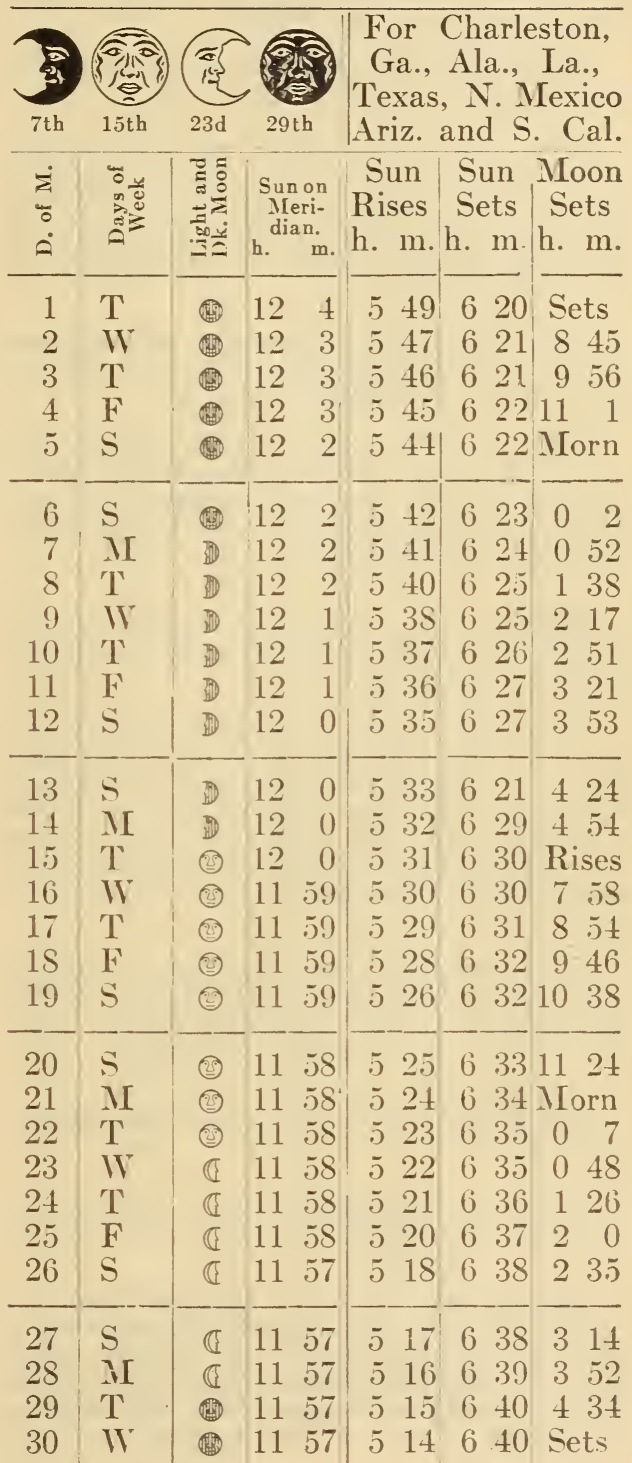

\section{SMALL ORDERS-IVE LIKE THEM}

A seed order for 10 cents worth is not too small to send to us. All orders, large and small are welcome at Huth's. We are glad to have your order, no matter how small, and the better results you will always get in your garden, always make it worth while to send to Huth's for the seed. Please don't think that a $\mathbf{1 0}$ to $\mathbf{5 0}$ cents order is too small to send to us. We fill tens of thousands of these small orders every year. They are always welcome and receive the same careful treatment and handling that larger ones do. Send your order in now. 
VEGETABLE GARDEN.-Sow as directed for April. Where Potatoes and Onions were taken up. Corn, Melons, Cucumbers, Squash ond Pumpkins can be planted.

All varieties of early cabbage can be sown this month.

During the hot weather Lettuce requires a good deal of water, as it will, if neglected, soon become hard and tasteless. In fact, it is combined with a good deal of labor to raise good Lettuce during the summer months. Okra can be sown.

Large White Solid Celery may be sown now but must be well shaded, and if the weather is dry, should be regularly watered.

Lima and Pole Beans can be planted, the Stringless Green, Kentucky Wonder and White Creaseback are the best varieties for late planting. Plant Pink and Pinto Frijole Beans and Tepary for shelling.

FIELD.-Cow Peas and Crowders can be planted, the latter is the best to be used green. Plant Blackeyed Peas.

Sweet Potato Slips or vines can still be set out, taking advantage of an occasional rain; but if it does not rain they must be watered. As the tops of Shallots get dry, which indicates their being ripe, they are fit to be taken up and stored away in a dry, airy place, taking care not to lay them too thick, as they are liable to heat.

Grass and Field Seeds, Sorghum, Field and Cow Peas, Soja and Velvet Beans, Millet, Milo Maize, Feterita, Egyptian Wheat, Field and Broom Corn can also be planted.

ORCHARD.-Besides Budding nothing can be done.

FLOWER GARDEN.-Follow instructions given for last month.

Mangel Wurzels make splendid Hog and Cattle food, are easily grown and amply repay the stock raisers who grow this valuable forage root. A trial will convince you of their value for fall and winter feeding. They also improve the health of animals and increase the milk yield of cows.

\section{May, 1919.}

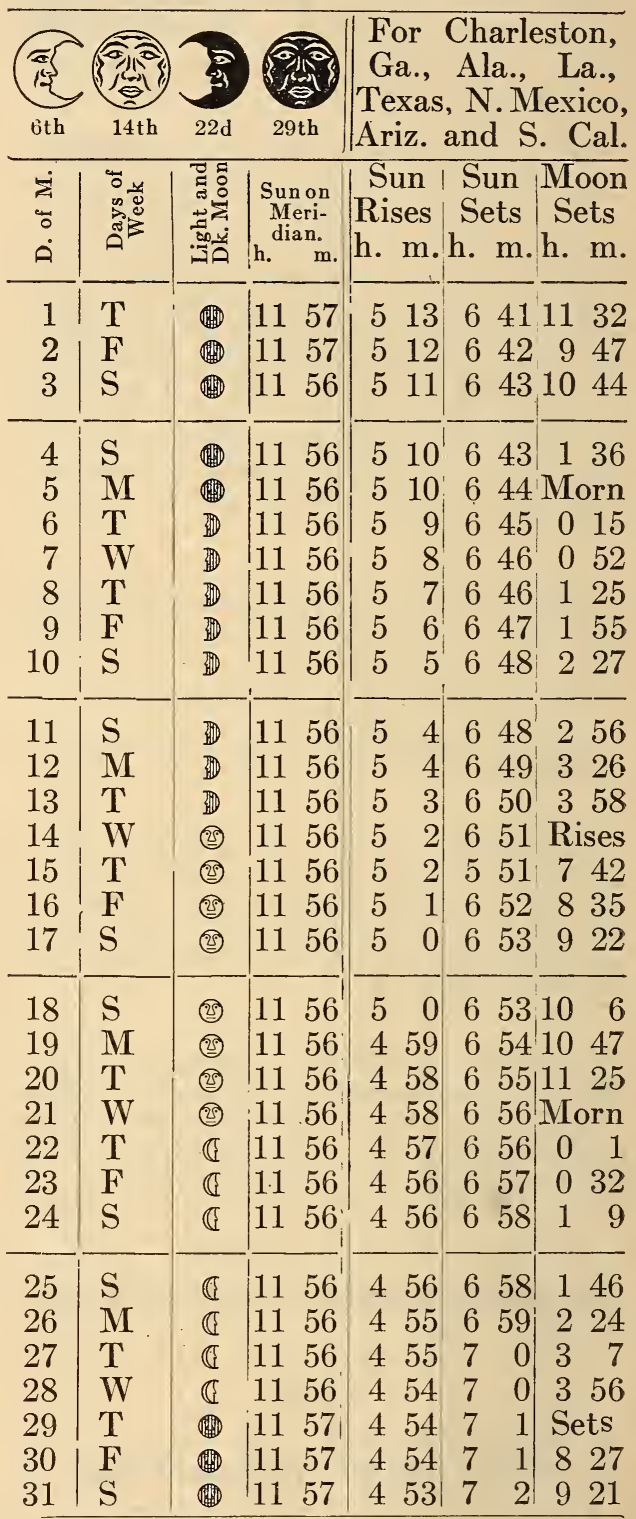

\section{OUR SEEDS}

are ail tested by our Grower before being shipped to us, and immediately upon their arrival here they are tested in the Standard Seed Tester and in the ground, thereby assuring perfect germination. It is to our interest to sell the very best seed. We are in the business to stay and are in the buisness fifty-four years, which is proof of itself of our faithfulness in selling the very best seed obtainable. 
VEGETABLE GARDEN.-The sowing during this month is similar to the preceding. The growing crops will require much attention as weeds grow fast at this time.

Corn may be planted for the last supply of roasting ears, also Water and Musk Melons. Cucumbers, Okra, Squash and Pumpkins planted during this month generally do well, but if the weather is hot and dry, they require an abundance of water.

Southern Prolific, Early Golden Cluster Wax, Kentucky Wonder and White Creaseback Pole Beans are the best to plant this month, as they stand more heat than other varieties. Continue to set out Sweet Potato slips or vines.

Sow all kinds of Radishes, Endive. Also Lettuce. Before sowing soak the seeds for two hours in water, take them out, put in a piece of cloth and set in a cool damp place, or if convenient in an ice box, which is best. Keep the cloth moist, and in four to six days the seeds will sprout. Then sow them. It is best to do so in the evening, and give a good watering.

If the seeds are sown without being sprouted, ants will be likely to carry them away before they can germinate, and the seedsman be blamed for selling seeds that did not grow. This sprouting has to be done from May to September, or, if the weather is warm and dry in the latter month, up to the middle of October.

Should the weather be moist and cool in the fall it can be dispensed with.

Cabbage for winter crops can be sown in this month, as the plants are generally easier raised during this than the following months.

Sow Tomatoes for late crop towards the end of this month.

FIELD.-Cow Peas, Canada Field Peas, Soja and Velvet Beans, Feterita, Egyptian Wheat, Sorghum and all varieties of Field Corn can still be sown. Plant Sweet Potato slips or vines for a late crop.

ORCHARD.-Nothing can be done.

FLOWER GARDEN.-Follow instructions given for April.

\section{THE MONEY SAVING CROPS}

are just about as important as any. Be sure and make plenty of grain and forage in 1919.

\section{June, 1919.}

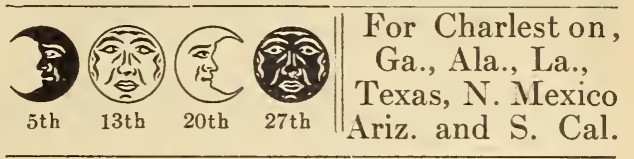

\begin{tabular}{|c|c|c|c|c|c|c|}
\hline $\begin{array}{l}\dot{\Sigma} \\
\dot{0} \\
\dot{0}\end{array}$ & 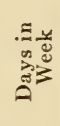 & 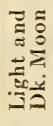 & $\begin{array}{l}\text { h. } \\
\text { Sun on } \\
\text { Meri- } \\
\text { dian. }\end{array}$ & $\begin{array}{l}\text { Sun } \\
\text { Rises } \\
\text { h. m. }\end{array}$ & $\begin{array}{l}\text { Sun } \\
\text { Sets } \\
\text { h. m. }\end{array}$ & $\begin{array}{l}\text { Moon } \\
\text { Sets } \\
\text { h. m. }\end{array}$ \\
\hline 1 & $\mathrm{~S}$ & (47) & 1157 & 453 & $\begin{array}{ll}7 & 2\end{array}$ & 108 \\
\hline 2 & M & (20) & 1157 & 453 & 7 & 1049 \\
\hline 3 & $\mathrm{~T}$ & (24) & 1157 & 452 & 7 & 1125 \\
\hline 4 & IV & (20) & 1157 & 452 & 7 & 1156 \\
\hline 5 & $\mathrm{~T}$ & (17) & 1158 & 452 & 7 & Morn \\
\hline 6 & $\mathbf{F}$ & $\mathbb{1}$ & 1158 & 452 & 5 & 029 \\
\hline 7 & $\mathrm{~S}$ & $D$ & 1158 & 452 & 7 & $0 \quad 59$ \\
\hline 8 & $\mathrm{~S}$ & Di & 1158 & 452 & 76 & 128 \\
\hline 9 & MI & Di & 1158 & 452 & 7 & 159 \\
\hline 10 & $\mathrm{~T}$ & D & 1159 & 451 & 7 & 234 \\
\hline 11 & IV & Di & 1159 & 451 & 7 & $\begin{array}{ll}3 & 13\end{array}$ \\
\hline 12 & $\mathrm{~T}$ & $D$ & 1159 & 451 & 8 & 355 \\
\hline 13 & $\mathbf{F}$ & (22) & 1159 & 451 & 7 & Rises \\
\hline 14 & $\mathrm{~S}$ & (2) & 1159 & 451 & 7 & 86 \\
\hline 15 & $\mathrm{~S}$ & (2) & 12 & 451 & 7 & 847 \\
\hline 16 & MI & (2) & 120 & 452 & 7 & 927 \\
\hline 17 & 'T & (2) & 120 & 452 & 710 & 103 \\
\hline 18 & IV & (2) & 12 & 452 & $\begin{array}{ll}7 & 10\end{array}$ & 1039 \\
\hline 19 & $\mathrm{~T}$ & (2) & 120 & 452 & 710 & 117 \\
\hline 20 & F & $\mathbb{1}$ & 12 & 452 & 710 & 1145 \\
\hline 21 & $\mathrm{~S}$ & (1) & 12 & 452 & $\begin{array}{ll}7 & 11\end{array}$ & Morn \\
\hline 22 & $\mathrm{~S}$ & $\mathbb{a}$ & 12 & 452 & 711 & 020 \\
\hline 23 & M & $\mathbb{C}$ & 12 & 453 & 711 & $0 \quad 59$ \\
\hline 24 & $\mathrm{~T}$ & $\mathbb{E}$ & 12 & 453 & 711 & 145 \\
\hline 25 & IV & ब & 12 & 453 & 712 & 236 \\
\hline 26 & $\mathrm{~T}$ & (1) & 12 & 454 & 712 & 332 \\
\hline 27 & $F$ & (24) & 12 & 454 & 712 & 435 \\
\hline 28 & S & (40) & 12 & 454 & 712 & Sets \\
\hline 2 & $\mathrm{~S}$ & (4) & 12 & 455 & 712 & 843 \\
\hline 30 & MI & (16) & 12 & 455 & 712 & 921 \\
\hline
\end{tabular}

\section{A GOOD FALL GARDEN IS A HELPER}

It helps a lot keeping down your store bills and gives a variety on your table. Too many have the idea that a fall garden should be limited to a turnip and collard patch. That turnip patch is a mighty good thing, but there are plenty of other vegetables as well-Beets, Beans, Cabbage, Lettuce, Radishes, Squash, Onions, Spinach, Kale, etc., all coming in and adding variety to your table health to yourself and family. Don't forget to plant a good fall garden. 
VEGETABLE GARDEN.--Towards the end of this month plant Pole and Bush Beans. In the early part sow Tomatoes for the last crop; also some Corn for roasting ears.

Cucumbers can be planted for pickling. Endive, Lettuce, all Radishes, as well as fall Cauliflower and Cabbage.

In new ground some Turnips and Ruta Bigt can be sown.

Plant all varieties of Cabbage mentioned in catalogue. Some seasons we have early frosts, and other seasons not before January, and Cabbage is most easily hurt by frost when heading up. When the plants are headed up, they are not so much affected by cold weather. It is, therefore, necessary to make two or more sowings at different times, so that in case some of the Cabbage is destroyed by frost, the other is coming on. As a general rule plants raised from seed sown in July and August give the best results, they are almost sure to head.

All Cabbage requires a strong, good soil, but the Surehead and Flat Dutch in particular.

The ground should be well fertilized with either stable manure, cotton seed meal or superphosphate, but we consider Cow Peas and Velvet Beans planted on the Cabbage land and plowed under the best and cheapest fertilizer.

A large quantity of seed must be sown at this time of the year, as it is sometimes very difficult to get a proper stand, and it is always better to have some plants left over than to be short.

It is a very difficult matter to protect the young Cabbage plants from the ravages of the insects, which are, especially after a mild winter, plentiful.

Strong Tobacco water or Tobacco dust has been found very beneficial; also Tobacco stems cut fine and scattered over the ground, will keep them off to some extent. Slug shot is also very good for this purpose.

FIELD.-Field Corn and Canada Peas. Feterita, Egyptian Wheat and Sorghum can be planted.

\section{July, 1919.}

\begin{tabular}{|c|c|c|c|c|c|c|c|}
\hline & 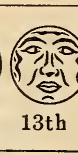 & & & & $\begin{array}{l}\text { For } \\
\text { Ga., } \\
\text { Texas } \\
\text { Ariz. }\end{array}$ & $\begin{array}{l}\text { Charle } \\
\text { Ala., } \\
\text { N.M } \\
\text { and S }\end{array}$ & $\begin{array}{c}\text { eston, } \\
\text { La., } \\
\text { Iexico, } \\
\text { S. Cal. }\end{array}$ \\
\hline $\begin{array}{l}\overrightarrow{\mathrm{z}} \\
\dot{\Delta} \\
\dot{\theta}\end{array}$ & 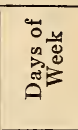 & 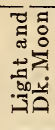 & $\begin{array}{l}\text { Sun } \\
\text { Mer } \\
\text { diar } \\
\text { h. }\end{array}$ & & $\begin{array}{l}\text { Sun } \\
\text { Rises } \\
\text { h. m. }\end{array}$ & $\begin{array}{l}\text { Sun } \\
\text { Sets } \\
\text { h. m. }\end{array}$ & $\mid \begin{array}{c}\overline{\text { Moon }} \\
\text { Sets } \\
\text { h. m. }\end{array}$ \\
\hline $\begin{array}{l}1 \\
2 \\
3 \\
4 \\
5\end{array}$ & $\begin{array}{l}\mathrm{T} \\
W \\
\mathrm{~T} \\
\mathrm{~F} \\
\mathrm{~S}\end{array}$ & 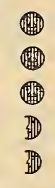 & $\begin{array}{l}12 \\
12 \\
12 \\
12 \\
12\end{array}$ & $\begin{array}{l}3 \\
3 \\
3 \\
4 \\
4\end{array}$ & $\begin{array}{ll}4 & 55 \\
4 & 56 \\
4 & 56 \\
4 & 57 \\
4 & 57\end{array}$ & $\left|\begin{array}{ll}7 & 12 \\
7 & 12 \\
7 & 12 \\
7 & 12 \\
7 & 11\end{array}\right|$ & $\left\{\begin{array}{rr}9 & 5 \\
10 & 2 \\
11 & \\
11 & 2 \\
11 & 5\end{array}\right.$ \\
\hline $\begin{array}{r}6 \\
7 \\
8 \\
9 \\
10 \\
11 \\
12\end{array}$ & $\begin{array}{l}\mathrm{S} \\
\mathrm{M} \\
\mathrm{T} \\
\mathrm{W} \\
\mathrm{T} \\
\mathrm{F} \\
\mathrm{S}\end{array}$ & 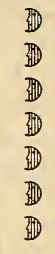 & $\begin{array}{l}12 \\
12 \\
12 \\
12 \\
12 \\
12 \\
12\end{array}$ & $\begin{array}{l}4 \\
4 \\
4 \\
4 \\
5 \\
5 \\
5\end{array}$ & $\begin{array}{lr}4 & 58 \\
4 & 58 \\
4 & 59 \\
4 & 59 \\
5 & 0 \\
5 & 0 \\
5 & 1\end{array}$ & $\begin{array}{ll}7 & 11 \\
7 & 11 \\
7 & 11 \\
7 & 11 \\
7 & 11 \\
7 & 10 \\
7 & 10\end{array}$ & $\begin{array}{cc}\text { Mor } \\
0 & 3 \\
1 & 11 \\
1 & 52 \\
2 & 37 \\
3 & 26 \\
\text { Rise }\end{array}$ \\
\hline $\begin{array}{l}14 \\
15 \\
16 \\
17 \\
18 \\
19\end{array}$ & $\begin{array}{l}\mathrm{S} \\
\mathrm{M} \\
\mathrm{T} \\
\mathrm{W} \\
\mathrm{T} \\
\mathrm{F} \\
\mathrm{S}\end{array}$ & $\begin{array}{l}\text { (2) } \\
\text { (2) } \\
\text { (2) } \\
\text { (2) } \\
\text { (2) }\end{array}$ & $\begin{array}{l}12 \\
12 \\
12 \\
12 \\
12 \\
12\end{array}$ & $\begin{array}{l}5 \\
5 \\
5 \\
5 \\
5 \\
6\end{array}$ & $\begin{array}{ll}5 & 1 \\
5 & 2 \\
5 & 2 \\
5 & 3 \\
5 & 4 \\
5 & 4 \\
5 & 5\end{array}$ & $\begin{array}{rr}7 & 10 \\
7 & 9 \\
7 & 9 \\
7 & 8 \\
7 & 8 \\
7 & 7 \\
7 & 7\end{array}$ & $\begin{array}{rr}7 & 27 \\
8 & 4 \\
8 & 37 \\
9 & 11 \\
9 & 48 \\
10 & 23 \\
10 & 59\end{array}$ \\
\hline $\begin{array}{l}25 \\
26\end{array}$ & $\begin{array}{l}\mathrm{S} \\
\mathrm{M} \\
\mathrm{T} \\
\mathrm{W} \\
\mathrm{T} \\
\mathrm{F} \\
\mathrm{S}\end{array}$ & $\begin{array}{l}\text { d } \\
\text { d } \\
\text { d } \\
\text { d } \\
\text { d } \\
\text { d } \\
\text { d }\end{array}$ & $\begin{array}{l}12 \\
12 \\
12 \\
12 \\
12 \\
12 \\
12\end{array}$ & $\begin{array}{l}6 \\
6 \\
6 \\
6 \\
6 \\
6\end{array}$ & $\begin{array}{ll}5 & 6 \\
5 & 6 \\
5 & 7 \\
5 & 8 \\
5 & 8 \\
5 & 9 \\
5 & 9\end{array}$ & $\begin{array}{ll}7 & 6 \\
7 & 6 \\
7 & 5 \\
7 & 5 \\
7 & 4 \\
7 & 4 \\
7 & 3\end{array}$ & $\mid \begin{array}{cc}11 & 41 \\
\text { Morn } \\
0 & 28 \\
1 & 21 \\
2 & 18 \\
3 & 22 \\
4 & 28\end{array}$ \\
\hline $\begin{array}{l}30 \\
31 \\
\end{array}$ & $\begin{array}{c}\mathrm{S} \\
\mathrm{M} \\
\mathrm{T} \\
\mathrm{W} \\
\mathrm{T}\end{array}$ & (17) & $\begin{array}{l}12 \\
12 \\
12 \\
12 \\
12\end{array}$ & & $\begin{array}{ll}5 & 10 \\
5 & 11 \\
5 & 11 \\
5 & 12 \\
5 & 13\end{array}$ & $\begin{array}{rr}7 & 2 \\
7 & 2 \\
7 & 1 \\
7 & 0 \\
6 & 59\end{array} \mid$ & $\mid \begin{array}{ll}\text { Sets } \\
7 & 52 \\
8 & 24 \\
8 & 59 \\
9 & 30\end{array}$ \\
\hline
\end{tabular}

\section{TREE TANGLEFOOT}

To protect trees against all climbing insect pests in the most effectual, economical and simple way, use TREE TANGLEFOOT. A sticky substance applied directly to tree trunks. Will not injure trees. Once applied remains sticky three to four months in all kinds of weather, or ten to twenty times as long as any other known substance. Easily applied with wooden paddle. A pound makes about 9 lineal feet of band. Needs no mixing, always ready for use. Far superior to burlap bands, that require daily inspection to give partial protection, while TREE TANGLEFOOT bands require only an occasional inspection to give absolute protection. For prices see page $\mathbf{1 0 7}$. 


\section{August, 1919.}

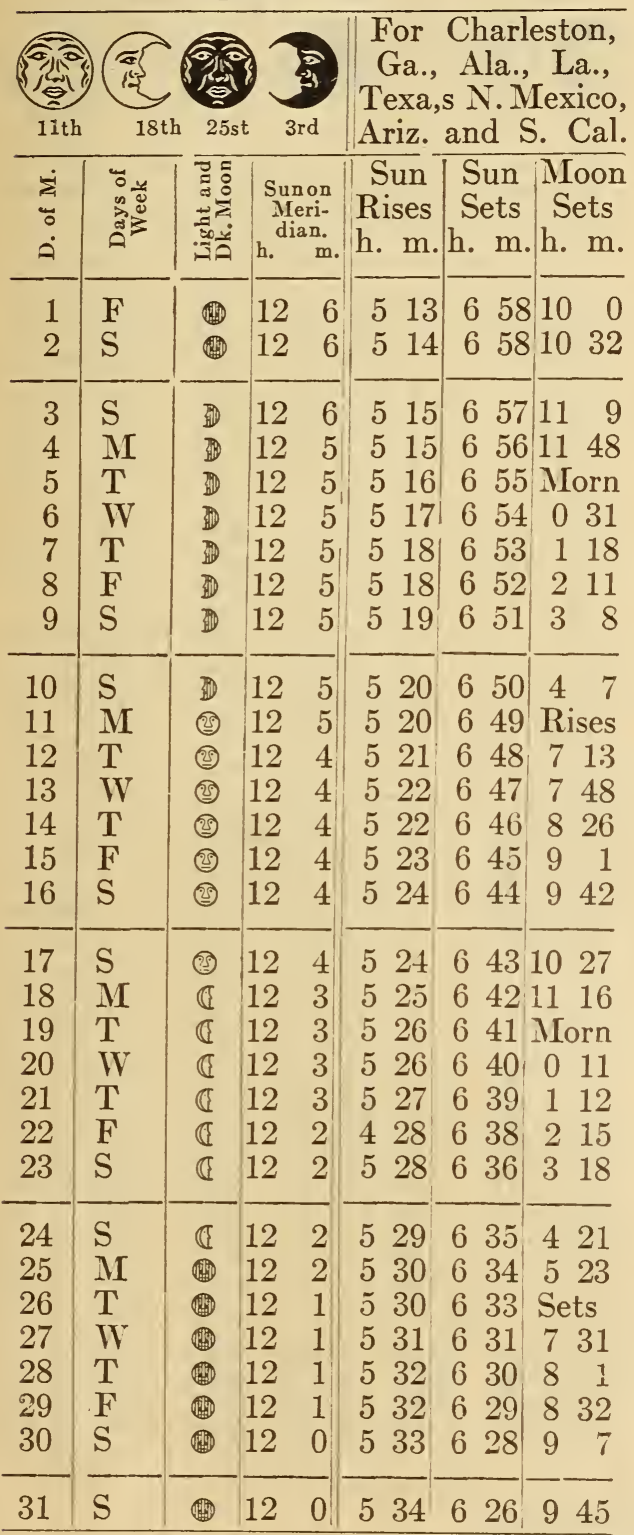

VEGETABLE GARDEN.-During this month gardeners in the South are very busy with sowing and planting Bush Beans, Pole Beans, Black Eyed Peas, Alaska, Gradus, First Best Peas can be planted, also all varieties of Cabbage and Cauliflower, Broccoli, Brussels Sprouts and Kale, Parsley, Chervil, Lettuce, Endive and Sorrel, but if the weather should be very dry, the seeds have to be frequently watered. It is best to cover Parsley seed with moss or brush until it begins to come up. All varieties of Radish should be sown.

Sow Swiss Chard, Mustard and Cress, all varieties of Turnip and Ruta Baga, and also Vienna Kohlrabi.

Carrots should be sown in the latter part; if the weather is favorable; but if hot and dry it is useless to do much, as seeds cannot come up well without being watered.

All varieties of Celery should be sown now.

If not too hot and dry, Beets of all kinds may be planted; but it is better to wait until the following month.

Set out Shallots, Onion Sets, Lima, Pinto, Tepary, Pink, Red and White Kidney Beans for shelling should be planted at the early part of this month.

Sow Tomatoes, Eggplants and Sweet Peppers for late crop.

If Celery plants are set out during this month they require to be shaded.

FIELD.-Potatoes saved from the spring crop, should be planted early this month for a winter crop; the smaller Potatoes are selected for that purpose and planted whole. Mexican June Corn can be planted in the early part of the month. Sow Cow and Field Peas, Velvet and Soja Beans, Millet and Sorghum.

ORCHARD. - Nothing can be done with any degree of success during this month.

FLOWER GARDEN.-Sow Balsams (Lady Slippers), Zinnia, Cockscomb, Gomphrena, etc., to bloom for November 1. Plant Spring annuals as described in this catalogue.

Inoculate with FARMOGERM and make better corps. See page 95 .

\section{BLUE BUG EXTERMINATOR}

Guaranteed to absolutely rid fowls of Blue Bugs, Lice, Fleas and other vermin or money refunded. Blue Bug Exterminator is not a dope that you have to catch the fowls to apply, but a food that is fed with the other feed. And we positively guarantee that Blue Bugs Lice or Fleas will not stay on fowls that are fed on this remedy. If little chicks are bothered with fleas, feed them 2 or 3 times with this food and the fleas will all drop off. Price $25 \mathrm{c}$ $40 c, 50 c$ and $\$ 1.00$ size. 
VEGETABLE GARDEN.-Mostly all seeds recommended for last month can be sown this month, but some more should be added to them.

In the early part plant bush beans, as they will bear before frost sets in. Also plant all early varieties of Peas. All kinds of Radishes Carrots, Beets, Parsnips, Salsify, Chervil, Parsley, Sorrel, Cress, Lettuce, Endive, Lerks, Turnips, Kohlrabi, Broccoli, Canlilower, Kale, Celery, Corn Salad and Mustard can be sown during this month.

Begin sowing Onion Seed of all varieties after the 15th of this month. As this is one of the most important crops, it should not be neglected.

Transplant Celery plants in ditches made for that purpose, and if the weather is favorable set out Lettuce, Beet, Cabbage and Cauliflower plants.

If the weather is not too hot and dry, Spinach may be sown, but has to be well watered, otherwise it is impossible to get a stand.

Some Cabbage seed can be sown, but Cabbage sown in this month will generally not do as well as seed sown during the previous month.

Set out, divide and transplant shallots, set out Onion sets and Chive plants, sow Sorrel and Turnip-rooted Celery.

FIELD.-Continue to plant Potatoes for an early winter crop. Use only small ones left over from a late spring crop, but do not cut them as they are apt to rot. Plow under the Cow Peas and prepare land to set out Cabbage and Cauliflower plants. Sow seed Rye, Barley, Wheat, Speltz, Vetches, all varieties of Clovers, Dwarf Essex Rape, Alialfa, Johnson, Ber muda, English Rye, Rescue, Guiena and Orchard Grasses, Rhodes Grass all varieties of Millet.

ORCHARD. - Continue to bud if the weather is not too dry and the stools remain in sap.

FLOWER GARDEN.-During this month flower seeds such as Pansy, Daisy, Sweet Alyssum, Candytuft, Stocks, Flowering Sweet Peas, Phlox, Chinese, Japan, Marguerite and Carnation. Pinks, Asters, etc., can be sown. Plant Hyacinth bulbs for early blooming at the end of the month. Sow on your lawn English Rye Grass for winter lawn.

\section{September, 1919.}

\begin{tabular}{|c|c|c|c|c|c|c|}
\hline \multirow[b]{2}{*}{$\begin{array}{l}\dot{\Sigma} \\
\ddot{0} \\
\dot{a}\end{array}$} & \multirow[b]{2}{*}{ 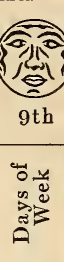 } & \multirow{2}{*}{ 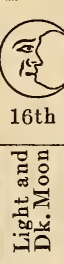 } & \multirow[b]{2}{*}{$\begin{array}{l}\text { Sun on } \\
\text { Meri- } \\
\text { dian. } \\
\text { h. m. }\end{array}$} & \multicolumn{3}{|c|}{$\begin{array}{l}\text { For Charleston, } \\
\text { Ga., Ala., La., } \\
\text { Texas, N. Mexico } \\
\text { Ariz. and S. Cal. }\end{array}$} \\
\hline & & & & $\begin{array}{l}\text { Sun } \\
\text { Rises } \\
\text { h. m. }\end{array}$ & $\begin{array}{l}\text { Sun } \\
\text { Sets } \\
\text { h. m. }\end{array}$ & $\begin{array}{l}\text { Mooh } \\
\text { Rises } \\
\text { h. m. }\end{array}$ \\
\hline 1 & $\mathrm{M}$ & (7id) & 120 & 534 & 625 & 1027 \\
\hline 2 & $\mathrm{~T}$ & 5 & 1159 & 535 & $\begin{array}{ll}6 & 24\end{array}$ & 1112 \\
\hline 3 & W & 政 & 1159 & 536 & 623 & Morn \\
\hline 4 & $\mathrm{~T}$ & DiD & 1159 & 536 & $\begin{array}{ll}621 \\
\end{array}$ & $\begin{array}{ll}0 & 1\end{array}$ \\
\hline 5 & $\mathrm{~F}$ & 挜 & 1158 & 537 & 620 & 056 \\
\hline 6 & S & 捙 & 1158 & 538 & 619 & 153 \\
\hline 7 & S & & 1158 & 538 & 618 & 252 \\
\hline 8 & M & Wiv & 1157 & 539 & $\begin{array}{ll}6 & 16\end{array}$ & 355 \\
\hline 9 & $\mathrm{~T}$ & (2) & 1157 & $\begin{array}{ll}5 & 39\end{array}$ & $\begin{array}{ll}6 & 15\end{array}$ & 51 \\
\hline 10 & W & (2) & 1157 & 540 & $\begin{array}{ll}624 \\
\end{array}$ & Rises \\
\hline 11 & $\mathrm{~T}$ & (2) & 1156 & 541 & $\begin{array}{ll}6 & 12\end{array}$ & \\
\hline 12 & $\mathrm{~F}$ & (2) & 1156 & $\begin{array}{ll}5 & 41\end{array}$ & $\begin{array}{ll}6 & 11\end{array}$ & 741 \\
\hline 13 & $\mathrm{~S}$ & (2) & 1156 & 542 & 610 & 826 \\
\hline 14 & $\mathrm{~S}$ & (3) & 1155 & 543 & 68 & 915 \\
\hline 15 & M & (2) & 1155 & 543 & & 108 \\
\hline 16 & $\mathrm{~T}$ & (1) & 1155 & $\begin{array}{ll}54 \\
5\end{array}$ & & $\begin{array}{ll}11 & 7\end{array}$ \\
\hline 17 & W & (1) & 1154 & 545 & & Morn \\
\hline 18 & $\mathrm{~T}$ & 0 & 1154 & 545 & 6 & 08 \\
\hline 19 & $\vec{F}$ & (8) & 1153 & 546 & & 110 \\
\hline 20 & $\mathrm{~S}$ & (1) & 1153 & 546 & 50 & 212 \\
\hline 21 & $\mathrm{~S}$ & & 153 & $\begin{array}{ll}547 \\
\end{array}$ & 559 & 313 \\
\hline 22 & M & (3) & 1152 & 548 & 557 & 415 \\
\hline 23 & $\mathrm{~T}$ & (id) & 1152 & 548 & 556 & $5 \quad 12$ \\
\hline 24 & W & (10) & 1152 & 549 & 555 & Sets \\
\hline 25 & $\mathrm{~T}$ & (19i & 1151 & 550 & 553 & 632 \\
\hline 26 & F & (19i4) & 1151 & 550 & 552 & $\begin{array}{ll}7 & 6\end{array}$ \\
\hline 27 & S & (19in) & 1151 & 551 & 551 & 743 \\
\hline 28 & S & & 0 & $5 \quad 52$ & 549 & 823 \\
\hline $2 ?$ & M & (19) & 1150 & 552 & 548 & 96 \\
\hline 30 & $\mathrm{~T}$ & (12iin & 1150 & 553 & 547 & 954 \\
\hline
\end{tabular}

\section{REGARDING INSECTS}

Of the hundreds of insects which attack plant-life there are two distinct classes-the "chewing" (eating) kind and the "sucking" kind. The "chewing" insects, such as beetles, caterpillars, etc., can be destroyed by spraying the foliage with a poison, such as Arsenate of Lead, which kills when it is eaten. On the other hand, the "sucking" insects feed by inscrting their sharp. slender beaks into the interior of the leaf, blossom etc,. They cannot eat plant tissue, and hence cannot eat poisons. They must therefore be destroyed with a preparation which kills by coming into contact with their bodies; in other words by a "contact" insectide. The most common sucking insecks, with soft bodies, are the aphids (plant lice), thrips and leaf-hoppers. They may be effectively controlled with "Black Leaf 40 ," a concentrated solution of nicotine su_phate guaranteed to contain $40 \%$ of nicotine by weight.

See page 107. 


\section{October, 1919.}

\begin{tabular}{|c|c|c|c|c|c|c|}
\hline & & & 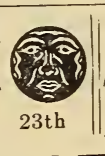 & $\begin{array}{l}\text { Ga., } \\
\text { Texas, } \\
\text { Ariz. }\end{array}$ & and $\mathrm{Se}$. & $\begin{array}{l}\text { eston, } \\
\text { La., } \\
\text { Lexico, } \\
\text {. Cal. }\end{array}$ \\
\hline $\begin{array}{l}\dot{z} \\
\dot{z}\end{array}$ & 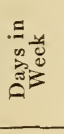 & 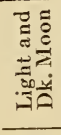 & $\begin{array}{l}\text { h. } \\
\text { Sun on } \\
\text { Meri- } \\
\text { dian. }\end{array}$ & $\left|\begin{array}{c}\text { Sun } \\
\text { Rises } \\
\text { h. m. }\end{array}\right|$ & $\begin{array}{c}\text { Sun } \\
\text { Sets } \\
\text { h. m. }\end{array}$ & $\begin{array}{l}\text { Moon } \\
\text { Rises } \\
\text { h. m. }\end{array}$ \\
\hline $\begin{array}{l}1 \\
2 \\
3 \\
4\end{array}$ & $\begin{array}{l}\mathrm{I} \\
\mathrm{F} \\
\mathrm{S}\end{array}$ & (17) & $\begin{array}{ll}11 & 49 \\
11 & 49 \\
11 & 49 \\
11 & 48\end{array}$ & $\begin{array}{ll}5 & 54 \\
5 & 54 \\
5 & 55 \\
5 & 56\end{array}$ & \begin{tabular}{ll|l}
5 & 45 & 1 \\
5 & 44 & 1 \\
5 & 43 & 1 \\
5 & 41
\end{tabular} & $\begin{array}{rr}10 & 45 \\
11 & 40 \\
\text { Morn } \\
0 & 38\end{array}$ \\
\hline $\begin{array}{r}5 \\
6 \\
7 \\
8 \\
9 \\
10 \\
11\end{array}$ & $\begin{array}{l}\mathrm{M} \\
\mathrm{T} \\
\mathrm{W} \\
\mathrm{T} \\
\mathrm{F} \\
\mathrm{S}\end{array}$ & $\begin{array}{l}\text { D) } \\
\text { Di } \\
\text { (1) } \\
\text { (2) } \\
\text { (2) } \\
\text { (2) }\end{array}$ & $\begin{array}{ll}11 & 48 \\
11 & 48 \\
11 & 48 \\
11 & 47 \\
11 & 47 \\
11 & 47 \\
11 & 46\end{array}$ & $\begin{array}{rr}5 & 56 \\
5 & 57 \\
5 & 58 \\
5 & 59 \\
5 & 59 \\
6 & 0 \\
6 & 1\end{array}$ & $\begin{array}{ll}5 & 40 \\
5 & 39 \\
5 & 38 \\
5 & 36 \\
5 & 35 \\
5 & 34 \\
5 & 32\end{array}$ & $\begin{array}{rr}1 & 37 \\
2 & 41 \\
3 & 46 \\
4 & 47 \\
\text { Rises } \\
6 & 16 \\
7 & 8\end{array}$ \\
\hline $\begin{array}{l}13 \\
14 \\
15 \\
16 \\
17 \\
18\end{array}$ & $\begin{array}{l}M \\
T \\
W \\
T \\
F \\
S\end{array}$ & $\begin{array}{l}\text { (2) } \\
\text { (2) } \\
\text { (2) } \\
\text { (1) } \\
\text { (1) }\end{array}$ & $\begin{array}{ll}11 & 46 \\
11 & 46 \\
11 & 46 \\
11 & 45 \\
11 & 45 \\
11 & 45 \\
11 & 45\end{array}$ & $\begin{array}{ll}6 & 2 \\
6 & 2 \\
6 & 3 \\
6 & 4 \\
6 & 4 \\
6 & 5 \\
6 & 6\end{array}$ & 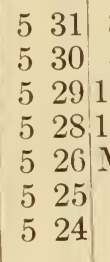 & $\begin{array}{rr}8 & 2 \\
8 & 59 \\
10 & 0 \\
11 & 5 \\
\text { Mrorn } \\
0 & 6 \\
1 & 8\end{array}$ \\
\hline $\begin{array}{l}22 \\
23 \\
24 \\
25\end{array}$ & $\begin{array}{l}\mathrm{S} \\
\mathrm{M} \\
\mathrm{T} \\
\mathrm{W} \\
\mathrm{T} \\
\mathrm{F} \\
\mathrm{S}\end{array}$ & 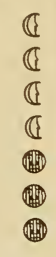 & $\begin{array}{ll}11 & 45 \\
11 & 44 \\
11 & 44 \\
11 & 44 \\
11 & 44 \\
11 & 44 \\
11 & 44\end{array}$ & $\begin{array}{rr}6 & 7 \\
6 & 8 \\
6 & 8 \\
6 & 9 \\
6 & 10 \\
6 & 11 \\
6 & 12\end{array}$ & $\mid \begin{array}{ll}5 & 23 \\
5 & 22 \\
5 & 21 \\
5 & 20 \\
5 & 18 \\
5 & 17 \\
5 & 16\end{array}$ & $\begin{array}{ll}2 & 8 \\
3 & 7 \\
4 & 1 \\
4 & 58 \\
5 & 56 \\
\text { Sets } \\
6 & 21\end{array}$ \\
\hline $\begin{array}{l}27 \\
28 \\
27 \\
30 \\
31 \\
\end{array}$ & $\begin{array}{l}\text { S } \\
M \\
T \\
\text { W } \\
T \\
\mathrm{~F}\end{array}$ & (17) & $\left|\begin{array}{ll}11 & 44 \\
11 & 44 \\
11 & 43 \\
11 & 43 \\
11 & 43 \\
11 & 43\end{array}\right|$ & $\begin{array}{ll}6 & 12 \\
6 & 13 \\
6 & 14 \\
6 & 15 \\
6 & 15 \\
6 & 16\end{array}$ & $\begin{array}{ll}5 & 15 \\
5 & 14 \\
5 & 13 \\
5 & 13 \\
5 & 12 \\
5 & 11\end{array}$ & $\begin{array}{rr}7 & 4 \\
7 & 50 \\
8 & 39 \\
9 & 32 \\
10 & 27 \\
11 & 24 \\
\end{array}$ \\
\hline
\end{tabular}

VEGETABLE GARDEN.-This is the month when Artichokes should be dressed, the suckers or sprouts taken off and transplanted.

Onion seed can be sown but it is better to get in the ground as soon as possible, so that the plants get large enough before cold weathcomes on.

Alaska, First and Best Peas can be planted.

Sow Cabbage, Spinach, Cauliflower, Broccoli, Brussels Sprouts, Kale, Mustard, Swiss Chard, Carrots, Beets, Salsify, Leeks, Corn Salad, Parsley, Chervil, Kohlrabi, Lettuce, Radishes Endive and Parsnips.

FIELD.-Speltz, Wheat, Rye, Barley and Oats should be planted for stock food, also Rhodes Grass, and all varieties of Clover. Alfalfa, English Rye, Rescue and all varieties directed for september.

ORCHARD.--Spray your fruit trees in order to destroy scale and other insects, and prepare land to set out more trees. If the weather is good and the trees are in sap, bud Orange trees.

Transplant Strawberry plants, they have to be transplanted every year, as they cannot be left in the same place for several years, as is done in the North.

Senator Dunlap, Excelsior, Michel's Early. Ocean City, Improved Hoffman, Lady Thompson and Klondyke are the favorite varieties for the Southern States.

FLOWER GARDEN. - Continue to sow Flower seeds of all spring blooming varieties. Plant Hyacinth, Narcissus, Ranunculus, Anemones, Tulip and Lily bulbs, Pansies. Daises, Sweet Alyssum, Candytuft, Petunias, Phlox, Verbenas, Columbine, Chinese, Japan and Carnation Pinks, Snapdragon. Flowering Sweet Peas, Sweet William, Stocks and Poppy Plant English Rye Grass for your winter lawn.

\section{TO MEASURE GRAIN IN THE BIN}

By the United States standard, 2,150 cubic inches makes a bushel; a cubic foot contains 1,728 cubic inches. Rule: Multiply the number of feet wide of bin by the length, the result by the depth, then divide the product by 5 and multiply the qoutient by 4 , which number wil give the quantity of bushels.

\section{THE FOLKS WITH A GOOD HOME GARDEN}

One of those good home gardens that is kept busy all the season, are always sure of a well One of those good home gardens that is kept busy a!l the season, are alwatime, for your health's
filled table of healthful food. Sommertime is vegetable growing and eating time
sake as well as your pocket's sake. There's nothing that will cut store bills quicker than a good home garden, the kind you grow from HUTH'S Seeds. 
VEGETABLE GARDEN.-During this month continue to sow all varieties of winter vegetables as during the previous month.

All varieties of Cabbage can be sown this month and they will make fine heads in the spring.

Sow Spinach, Lettuce, Radishes, Beets, Turnips, Mustard and all fast growing vegetables.

Hot-beds should be gotten ready now for Cucumbers, manure for same should be looked after, it ought not to be over one month old. Set out Shallots, Chives, and Onion Sets.

FIELD.-Continue to sow all varieties of Grasses, Field and Clover Seed as directed for September and October.

ORCHARD.-Prepare your land to set out fruit trees, transplant those which are dormant.

FLOWER GARDEN.-Sow Flower seeds of all kinds in boxes and transplant when large enough into open ground, such as Pansy, Daisy, Phlox, Petunia, Chinese and other Pinks, Alyssum, Candytuft, Larkspur, Lobelia and Poppy. Sow Sweet Peas.

Set out roses and other hardy plants, in December.

Plant Hyacinths, Tulips, Narcissus, Jonquils, Anemones and Ranunculus in open ground or flower pots for forcing.

To force Hyacinths and other bulbous rooted plants in flower pots, use light but rich soil, plant in 5 inch pots, so that the top of the bulbs are covered half an inch.

Give one good watering and bury the pots 6 inches under the ground, until the bulbs are well rooted, which takes from 4 to 5 weeks. When well rooted take the pots out of the ground and gradually expose to the light, when they will soon put out and bloom well. Plant English Rye Grass for your winter lawn.

\section{November, 1919.}

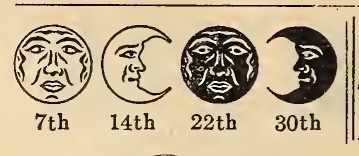

For Charleston, Ga., Ala., La., Texas, N. Mexico, Ariz. and S. Cal.

\begin{tabular}{|c|c|c|c|c|c|c|}
\hline $\begin{array}{l}\stackrel{\dot{a}}{\mathrm{i}} \\
\ddot{\circ} \\
\dot{0}\end{array}$ & 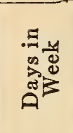 & 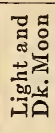 & $\left|\begin{array}{c}\text { h. m. } \\
\text { Sunoon } \\
\text { Meri- } \\
\text { dian. }\end{array}\right|$ & $\mid \begin{array}{c}\text { Sun } \\
\text { Rises } \\
\text { h. m. }\end{array}$ & $\begin{array}{c}\text { Sun } \\
\text { Sets } \\
\text { h. m. }\end{array}$ & $\begin{array}{l}\text { Moon } \\
\text { Rises } \\
\text { h. m. }\end{array}$ \\
\hline 1 & $\mathrm{~S}$ & $\mathbb{1}$ & 1143 & $\begin{array}{ll}617 \\
\end{array}$ & $\begin{array}{ll}5 & 10\end{array}$ & Morn \\
\hline 2 & 5 & TiD & 1143 & $\begin{array}{ll}6 & 18\end{array}$ & $\begin{array}{ll}5 & 9\end{array}$ & $\begin{array}{ll}0 & 24\end{array}$ \\
\hline 3 & $\mathrm{M}$ & 政 & $\begin{array}{ll}11 & 43\end{array}$ & $\begin{array}{ll}6 & 19\end{array}$ & 58 & 127 \\
\hline 4 & $\mathrm{~T}$ & 亚 & 1143 & 620 & 57 & 227 \\
\hline 5 & W & iiD & 1145 & $\begin{array}{ll}621 \\
\text {. }\end{array}$ & 56 & 332 \\
\hline 6 & $\mathrm{~T}$ & iiD & 1143 & 622 & 5 & 441 \\
\hline 7 & $\mathrm{~F}$ & (2) & 1143 & 622 & 5 & 552 \\
\hline 8 & $\mathrm{~S}$ & (2) & 1143 & 623 & 5 & Rises \\
\hline 9 & & (2) & 1143 & 625 & 53 & 645 \\
\hline 10 & $\mathrm{M}$ & (2) & 1143 & 624 & 52 & 748 \\
\hline 11 & $\mathrm{~T}$ & (2) & 1144 & 626 & 52 & 854 \\
\hline 12 & W & (2) & 11.44 & 627 & & 957 \\
\hline 13 & $\mathrm{~T}$ & (2) & 1144 & 628 & 50 & 11 1 \\
\hline 14 & $\mathrm{~F}$ & ( & 1144 & 629 & 50 & Morn \\
\hline 15 & $\mathrm{~S}$ & (1) & 1144 & 630 & 459 & $\begin{array}{ll}0 & 2\end{array}$ \\
\hline 16 & $\mathrm{~S}$ & (8) & 1144 & 31 & 459 & 1 \\
\hline 17 & M & (1) & 1144 & 632 & 458 & 156 \\
\hline 18 & $\mathrm{~T}$ & di & 1145 & 632 & 458 & 253 \\
\hline 19 & W & $\mathbb{8}$ & 1145 & 633 & 457 & 350 \\
\hline 20 & $\mathrm{~T}$ & $\mathbb{1}$ & 1145 & 634 & 457 & 446 \\
\hline 21 & $\mathrm{~F}$ & (1) & 1145 & 635 & 456 & $\begin{array}{ll}5 & 41\end{array}$ \\
\hline 22 & $\mathrm{~S}$ & (iDi & 1146 & 636 & 456 & 635 \\
\hline 23 & $S$ & (19it) & 1146 & 637 & 456 & Sets \\
\hline 24 & M & (17) & 1146 & 638 & 555 & 634 \\
\hline 25 & $\mathrm{~T}$ & (19ing & 1146 & 639 & 455 & 726 \\
\hline 26 & W & (7id) & 1147 & 640 & 455 & 821 \\
\hline 27 & $\mathrm{~T}$ & (17id & 1147 & $\begin{array}{ll}6 & 41\end{array}$ & 454 & $\begin{array}{ll}9 & 17\end{array}$ \\
\hline 28 & $\mathrm{~F}$ & (ingis & 1147 & $\begin{array}{ll}642 \\
\end{array}$ & $\begin{array}{ll}4 & 54\end{array}$ & 1014 \\
\hline 29 & $\mathrm{~S}$ & (iDi & 1148 & $\begin{array}{ll}6 & 42\end{array}$ & 454 & $11 \quad 14$ \\
\hline 30 & $\mathrm{~S}$ & 恶 & 1148 & 643 & 454 & \\
\hline
\end{tabular}

\section{THEY STAND THE TEST-HUTH SEEDS-THEY ARE THE BEST}

Nothing in this world is more disappointing than to spend your time and money preparing your ground, fertilizing it, seeding it, cultivating it, watching it, only to find the crop, when you should be enjoying it, a FAILURE.

It is not possible to guard against this entirely, so much depends upon the care with which the ground is prepared, the seeds planted, afterwards cultivated, etc., and the weather may be unfavorable, but ONE thing EVERYONE can do-PLANT ONLY THE BEST SEEDS. Do not be content with anything less than the best. It is not worth while. There is too much at stake. It does not pay to wait until they are above ground to see whether they are going to grow. The time to find this out is BEFORE YOU PLANT THEM.

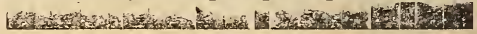




\section{December, 1919.}

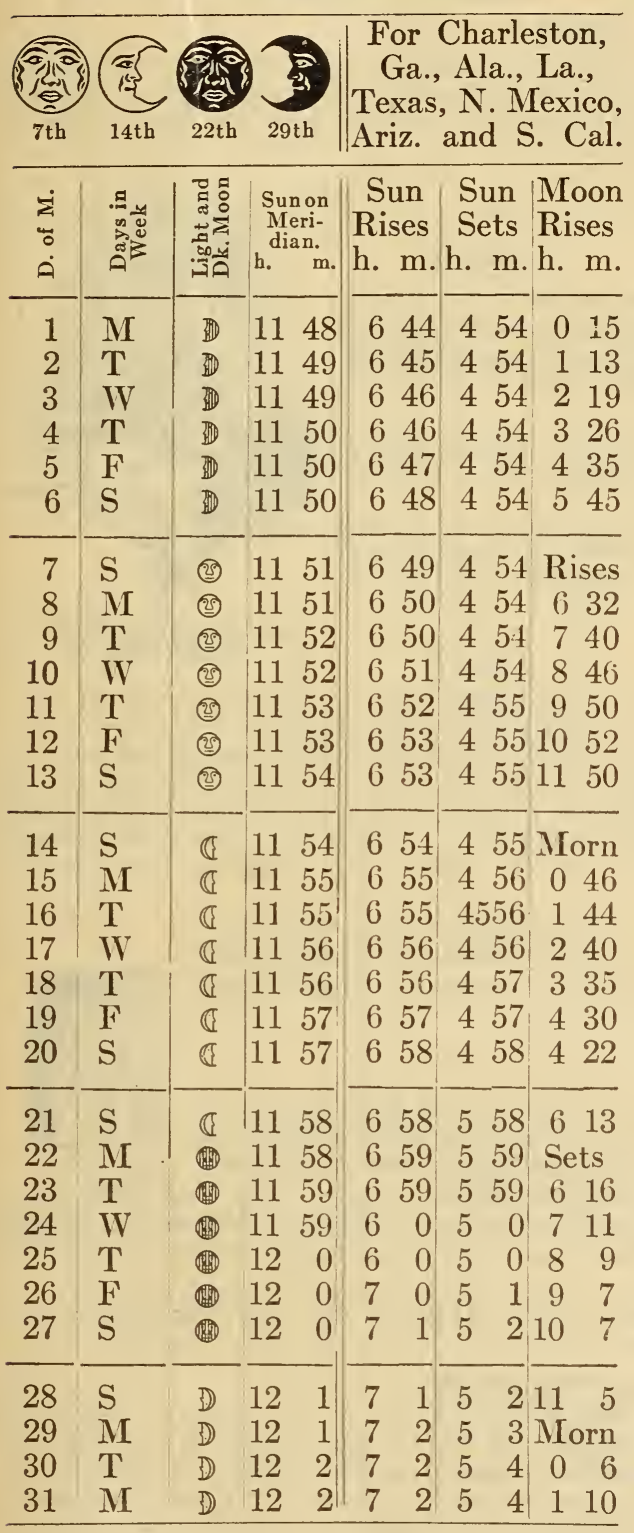

VEGETABLE GARDEN.-Peas for general crop can be planted.

Spinach, Radishes, Carrots, Lettuce, Endive, and some early Cabbage may be sown.

Sow early varieties of Cauliflower in a frame or a sheltered situation in the open ground to be transplanted in February.

In the latter part of this month sow Peppers, Cucumbers, Eggplants in the hot-bed.

Sow Tomatoes for forcing in a cooled-off hot-bed.

Set out Shallots, Chives, and Onion Sets

FIELD.-Sow Lespedeza or Japan Clover, Alfalfa, Red, Alsike, Burr, White and Crimson Clover, all varieties of Grass seed, Speltz, Rye, Barley, Wheat and Oats for stock food.

ORCHARD.-Prepare ground for fruit trees during this month, and towards the end begin to plant.

Plant Pecan Nuts to raise trees from.

Prune, work and fertilize trees which have been planted during the previous season. i

FLOWER GARDEN.-Plant Hyacinths, Tulips, Narcissus, Jonquils, Ranunculus, Anemones Japan Lilies. Sow all varieties of winter and spring blooming flower seeds in cold frames to be set out in January and February, as for instance Lobelia, Asters, Pansy, Daisy Phlox, Petunia, Chinese and other Pinks, Alyssum. Candytuft, Larkspur, Poppy, Hollyhock, Snapdragon, Adonis, Calleopsis, Heliotrope, Primula and Reseda. Set out Roses and other hardy plants, and all varieties of Herbs. Plant English Rye grass for your winter lawn.

Plant Sweet Peas.

\section{STRAWBERRIES}

Along with the year 'round gardening for health's sake and the pocket's sake, why not plant some of the extra good things in the fruit and berry line as well.

\section{NOTICE}

Have you hay, grain, produce, truck, hogs, cattle, etc., for sale and don't know the names of buyers just let us know what you have and we will gladly assist you.

\section{PLANT A GOOD FALL GARDEN AND SAVE YOURSELF MONEY}

That's an exact fact. Every farm and back yard garden in town is a money saver. Every mess of vegetables from the garden cuts down the store bill just that much. Plant a real fall garden this year. It can save you almost as much as a good spring garden. Give the fall garden a square deal and it will surprise you by its money-saving capacity. 


\section{STANDARD VARIETIES OF VEGETABLES \\ SEEDS BY MAIL}

We will send, postage paid, all Vegatable-and Flower-Seeds, at the prices given in this Catalog, except heavy seeds, such as Beans, Peas, Corn, Field Seeds, Grass Seeds and Onion Sets. If these are wanted by mail it will be necessary to add to the remittance 5 cents per pound in small lots or in larger quantities regular parcel post charges. See page 2.

\section{Artichoke}

\section{ARTICHOKE}

CULTURE. Sow in February in rich soil and transplant the following spring to permanent beds (in rows or hills) three feet apart and two feet between the plants. Green Artichoke gives only partial crop the first of the season, but the beds will be bearing for years. Protect in winter by covering of leaves or coarse manure.

LARGE GREEN GLOBE. The standard variety. Produces large, globular heads, scales, green shading to purple. Pkt. 5c; oz. 35c; $1 / 4 \mathrm{lb} \$ 1.00$.

JERUSALEM ARTICHOKE. Cultivated for its roots, which make an excellent crop for stock feeding. Tubers in season. $10 \mathrm{c}$ per pound, parcel post extra. For full description and prices in quantities, see field section, page 97.

\section{Spargel.}

\section{ASPARAGUS}

CULTURE. The seed can be $s_{\text {own }}$ in any garden soil and should be sown in rows about 14 inches apart as early in the spring as possible. Cultivate thoroughly and thin plants to three inches in the row. The permanent bed should be of deep, rich, loamy soil, well stirred, and as these beds must bear for a good many years they should be well manured and fertilized. If the soil is of stiff clay it should be loosened up by using plenty of sand or even coal ashes. Have rows from two to four feet apart and set the plants a foot apart and at least six inches below the surface. Cut sparingly the second season but after that the beds will yield full crops. One ounce of seed will produce about 250 plants and it takes four to five pounds to the acre.

For full directions how to grow Asparagus, get our Asparagus Book by Hexamer. Price 50 cents.

COLUMBIAN MAMMOTH WHITE. A magnificent variety. It furnishes fine, white shoots, which stay white as long as they are fit to use without any artificial means of blanching. Pkt. 5c; oz. 10c; $1 / 4$ lb. 25c; lb. $70 c$.

CONOVER'S COLOSSAL. The standard sort, of a large size and excellent quality. Pkt. 5c; oz. 10c; $1 / 4$ lb. 25c; lb. 70c.

EARLY ARGENTINE. Just recently introduced. It is very early and of exiremely vigorous habit, two qualities which make this variety less apt to attacked by rust. The flavor of the stalk is very delicious. It is appreciated wherever there are people who relish Asparagus. Pkt. 5c; oz. 10c; $1 / 4$ lb. 40c; lb. \$1.00.

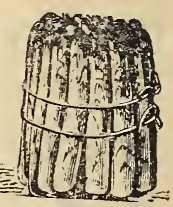

PALMETTO. Of bright green appearance, very large size and even, regular growth, Its immense productiveness combined with earliness and good qualities, make it a fine variety for general use. Pkt. 5c; oz. 10c; $1 / 4$ lb. 25c; 1b. 70c.

ROOTS OF THE ABOVE VARIETIES._-25 c per do zen; $\$ 1.00$ per 100. Price for larger quantities on application.

\section{DON'T WAIT UNTIL THE BUGS}

have eaten up half your crop before you begin to think about a remedy. You can be reasonably sure that Mr. and Mrs. Bug are going to come around and try to raise several Bug families in your patch. The right way, the safe way, is to keep Bug Death around the house and at the first sign of Mr. Bug's appearance in your crops, either dust or spray the plants with Bug Deathfiand Mr. and Mrs. Bug will shortly be in a condition that will make the raising of "Bug" families impossible in your neighborhood. It will be a bug funeral instead of a large increase in the family, and in the meantime your crops will go on to maturity uninjured. You may think it strange that we say "dusted or spraved" on the plants. That's exactly correct and one method is as good as the other. If you have a powder gun or shaker you can dust the fine powder on the plants when they are wet with rain or dew and it will stick so tight that it will take the hardest kind of rain to wash it off. If you have a sprayer, and are working on a large scale, dissolve about 12 to 15 pounds of Bug Death in 12 quarts of clean water and spray it on. This much will go over an acre of vegetables and the bugs will quit eating the leaves of your plants in a hurry. For prices see Page 106. 


\section{BUSH BEANS.}

\section{NOTICE}

We are selling everything by the pound. A pound of beans is equal to a little more than a pint.

In ordering beans, peas and sweet corn, grass and other field seeds by mail, please add postage 5 cents per pound in small lots and regular parcel post charges for larger quantities. See Page 2.

CULTURE. Plant in drills about two inches deep and from 18 inches to two feet apart, according to the richness of the soil-the poorer the soil the closer the rows can be, and the plants should be about 4 inches apart. A succession of sowings can be made from the first week in February until September One pound to 60 feet of drill: 1 to $1 \frac{1}{2}$ bushels to the acre.

\section{STRINGLESS GREEN POD}

The best green podded bean on the market. It is very early extremely vigorous and produces an abundance of brittle stringless pods. Pkt. 5c; $1 / 2$ lb. 20c; 1 lb. 40c.

\section{EXTRA EARLY RED VALENTINE}

An old favorite and has only recently been surpassed by the Stringless Green Pod. Very prolific and the pods are fine and round, and very tender while young. It is as early as the preceeding one, but the pods are not quite as long nor as straight. Pkt. 5c; 1/2 lb. 20c; 1b. 40c.

\section{EARLY YELLOW SIX WEEKS}

The pods are long and flat and of a bright green color. Plants form erect bushes. Pkt. 5c; $1 / 2$ lb. 20c; lb. 40c.

\section{EXTRA EARLY REFUGEE OR BROWN SPECKLED VALENTINE}

This may be called one of the second early sorts. Pods are round, of good flavor, but because of the great vigor of the bush it needs twice the usual room. Pkt. $5 \mathrm{c} ; 1 / 2 \mathrm{lb} .20 \mathrm{c} ; 1 \mathrm{~b} .40 \mathrm{c}$.

\section{GIANT STRINGLESS GREEN POD VALENTINE}

The round meaty pods resemble the Early Red Valen-

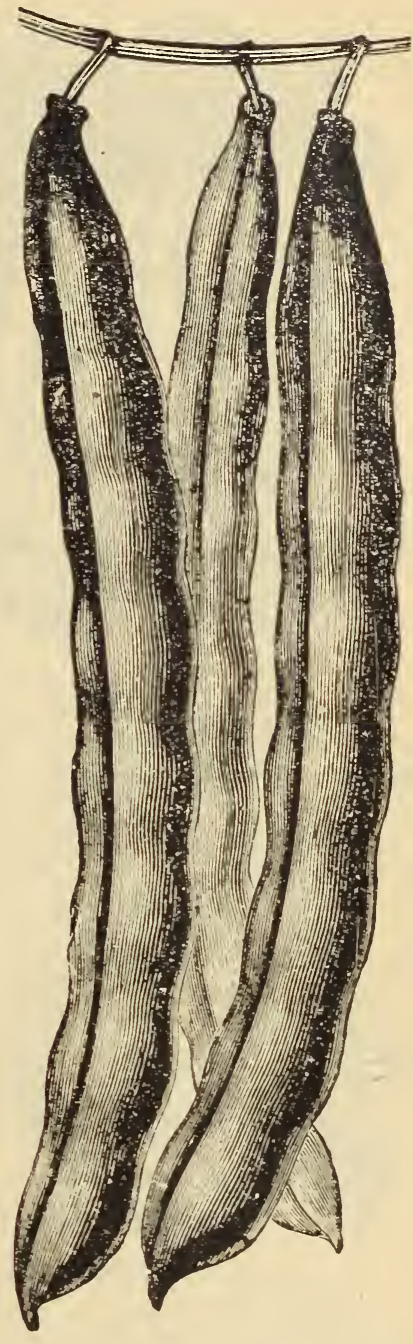

Stringless Green Pod

tine, but this bean matures a week or ten days later. The pods are quite stringless and brittle at all stages and this variety is to be recommended highly. Pkt. 5c;1/2 lb. 20c; 1 lb. 40c.

\section{DWARF HORTICULTURAL}

An excellent soup bean in summer, a fine baking bean in winter. Pkt. 5c; 1/2 lb. 20c; 1 lb. 40c.

\section{LARGE WHITE MARROWFAT}

The standard white soup beans. Pkt. 5c; $1 / 2 \mathrm{lb} .20 \mathrm{c} ; 1 \mathrm{lb} .40 \mathrm{c}$.

\section{BROAD WINSDOR}

Quite hardy and consequently can be planted very early. Pkt. 5c; 1/2 lb. 20c; 1 lb. 40c.

\section{HUTH'S STRINGLESS GREEN POD}

We offer this new stringless bean, which is not only of fine quality, but especially valuable, being a week or ten days earlier than other stringless varieties, The plant is small, bushy, very erect, compact, of well-rounded form and prolific. Pods are about $4 \frac{1}{2}$ inches long, straight, bright green, oval round through cross section and contain 5 to 6 seeds. The seeds are yellowish and of good size, Pkt, 10c; 1/2 lb, 20c; lb, 40c. 


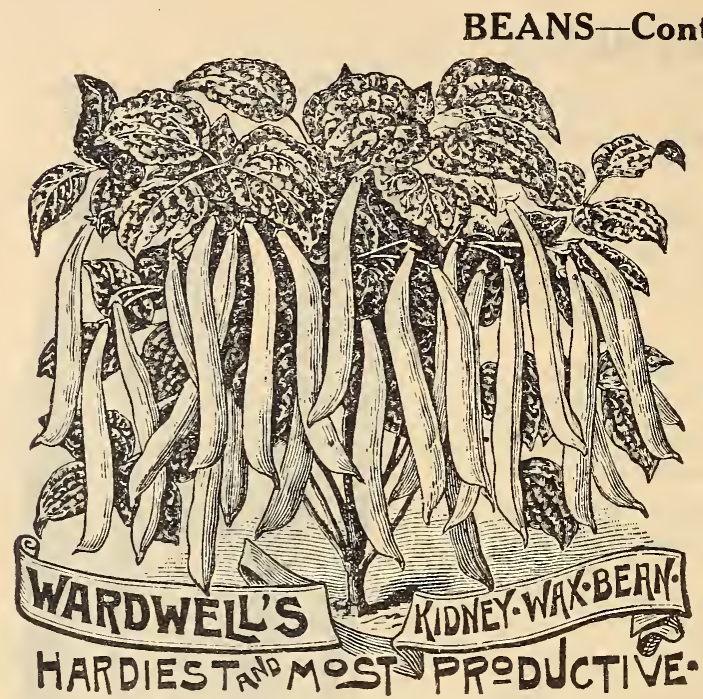

\section{WAX PODS.}

\section{DAVIS' WHITE WAX}

This bean does not discolor, and is therefore excellent for canning. It is immensely productive and a very good shipper. The pods are straight and 5 to 6 inches in length The dry bean is white and very desirable for winter use. Pkt. 5c; $1 / 2$ lb. 20c; 1 lb. 40c.

\section{IMPROVED GOLDEN WAX. (Rust Proof.)}

The standard wax bean for years. The pods are large, slightly flattened, brittle, quite stringless when young and of golden wax color. It is very tender, of fine flavor, and is excellent as a shell bean for winter use. The bushes are of compact growth and very prolific. Pkt. 5c; $1 / 2 \mathrm{lb} .20 \mathrm{c} ; 1 \mathrm{lb} .40 \mathrm{c}$.

\section{DWARF BLACK WAX}

Sometimes called Butter Beans. One of the earliest varieties, producing fine, round meat, pods of good quality. Pkt. 5c; $1 / 2$ lb. 20c; lb. 40 .

\section{WARDWELL'S KIDNEY WAX}

Highly recommened for private planters and market gardeners. The pods are flat, straight, and are produced in large quantities. Pkt. $5 \mathrm{c} ; 1 / 2 \mathrm{lb} .20 \mathrm{c} ; 1 \mathrm{lb} .40$.

\section{PENCIL POD BLACK WAX}

Plant grows about 15 inches high, very productive, with straight pods 6 to 7 inches long, light golden yellow color, round, meaty and deeply saddlebacked; flesh brittle, solid and stringless; flavor fine. Pkt. 5c; $1 / 2$ lb. 20c; 1 lb. 40c.

\section{CURRIE'S RUST PROOF BLACK WAX}

As near rust proof as a good bean can be. Very vigorous and hardy and productive. Pkt. 5c; $1 / 2$ lb. 20c; 1 lb. 40 c.

\section{BUSH LIMA BEANS}

\section{FORDHOOK BUSH LIMA}

This potato lima was bred from the old Kummerle or Dreer Bush Lima and is much superior to its parent. It has the very excellent habit of growing stiffly erect and therefore keeping its bean off the ground. Contact with the ground discolors beans and is very detrimental to them. The plants are about 30 inches high and bear an immense crop of fine large pods. The pods are borne in clusters of from five to eight and measure five to six inches long. The beans are delicious and mature eight to ten days earlier than other bush limas.

Pkt. 10c; $1 / 2$ lb. 20c; 1 lb. 40c;

\section{BURPEES'S BUSH LIMA}

This is the bush form of the Large White Lima. The bush is about 20 inches high and up to two and a half feet in diameter bearing from 50 to 100 large pods. Pkt. 5c; $1 / 2 \mathrm{lb}$. 20c; lb. 40c

\section{HENDERSON'S BUSH LIMA}

This bean is about two weeks earlier than the Pole ima. It needs no stakes and produces an enormous crop of df cious Lima Beans. Pkt. 5c; 1 lb. 40c.

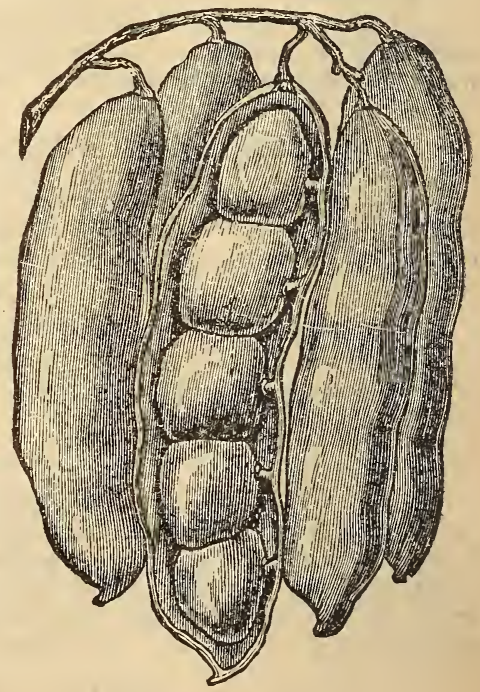




\section{BEANS-Continued.}

\section{Stangenbohnen}

\section{POLE OR RUNNING VARIETIES}

Postage 5 cents per pound in small lots and regular parcel post charges in quantities.

BURGER'S GREEN STRINGLESS. This bean has surpassed the old Kentucky Wonder, it being earlier and bearing for a longer time. The pods are stringless and up to eight inches long, dark green, very tender, and have a delicious flavor. The dry beans are white. Pkt. $5 c$; lk 0 c.

KENTUCKY WONDER OR OLD HOMESTEAD. This has been for a long time the most popular bean. It is very vigorous, climbs well, and bears abundance of nearly round pods which are often ten inches long. Pkt. 5c;lb.40c.

WHITE CREASEBACK. Extremely early and matures all its pods at the same time. Vines are medium sized but wonderfully productive in good soil. The pods are quite round, quite fleshy, medium sized, silvery green, and are borne in clusters of four to twelve. Are excellent snap beans, fine shippers, and are especially fine for baking. Pkt. 5c; $1 \mathrm{lb} .40 \mathrm{c}$.

LAZY WIFE. So named because of the easy picking, and a very popular bean in some localities. Pods are broad, thick, very fleshy, entirely stringless and of a rich buttery flavor when cooked. The beans are white and make a good dry bean for winter use. Pkt. 5c; 1 lb. 40c.

CUT SHORT OR CORN HILL. The old standard for plant ing among corn. Pods are short, round and tender. Pkt. 5c; $1 \mathrm{lb}$. 40c.

WHITE DUTCH CASEKNIFE. Pods are large, flat, and green. Can be either snapped or shelled. Pkt. 5c; $1 \mathrm{lb}, 40 \mathrm{c}$.

HORTICULTURAL OR SPECKLED CRANBERRY. A showy bean and matures in eighty days. Pods are green, dashed with red, valued as a snap or for shelling. Pkt. 5c; 1 lb. 40c.

EARLY GOLDEN CLUSTER WAX. The only wax bean among the pole varieities. It bears from July until frost and the pods are six to eight inches long and come in clusters from three to six. The flavor is most excellent. Pkt. 5c; $1 \mathrm{lb} .40 \mathrm{c}$.

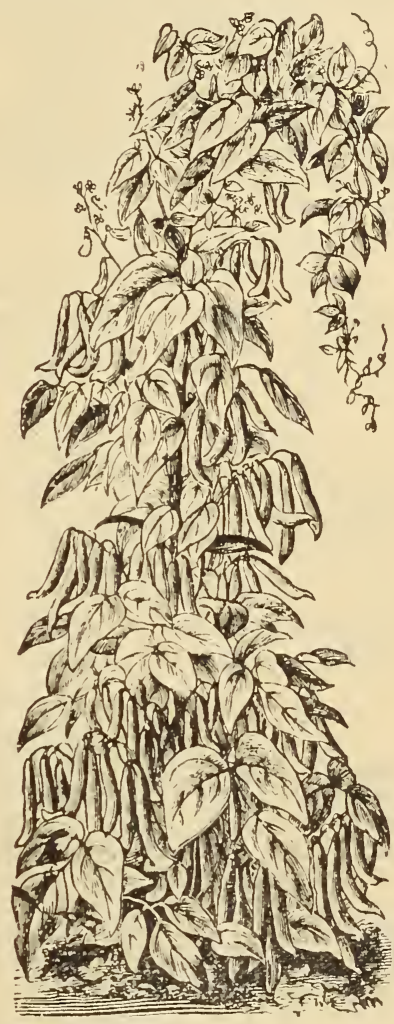

KENTUCKY WONDER

\section{FLOWERING BEANS}

SCARLET RUNNER. Has a fine scarlet flower and is very desirable for covering trellises, old fences, etc. The green pods are edible. Pkt. 5c; lb. 40c.

\section{POLE LIMA BEANS}

LARGE WHITE LIMA OR BUTTER BEANS. The old favorite and of fine flavor. Pkt. 5c; $1 \mathrm{lb} .40 \mathrm{c}$.

SMALL CARLOINA, OR SIEVA LIMA. This is a small type of the pole limas. It matures quickly, produces immense crops, and makes an excellent bean for winter use. Pkt. 5c; 1 lb. 40c. 


\section{TABLE BEETS.}

Betrave (Fr.), Roth-Ruben (Ger.), Remolacha (Sp.), Barbabietola (Ital.).

CULTURE. Little art is necessary for the cultivation of this vegetable. One grand essentia] for an early crop is to dig or plow deep and manure or fertilize well, and sow as early in the Spring as the soil will admit of working; draw drills half an inch deep and eighteen inches apart; sow the seed thinly, cover them thinly, and rake finely: before raking sow a sprinkling broadcast of Early Radish Seed, as they will be fit for pulling before the Beets are ready for thinning, which will be in about four weeks, As soon as the Beets have formed a few leaves, thin them out to three inches apart, allowing the strongest plants to remain. For a Winter crop sow late in Spring or early Summer; on the approach of frost take up the root and cut the leaves off to about two inches of the crown, store them in pits secure from frost, or in a cool, dry cellar, covered with earth or sand. The seeds will always vegetate much sooner by soaking them in water six to twelve hours before sowing. The young plants can also be successfully transplanted during moist weather. One ounce to 100 feet of drill; 6 to 8 pounds to the acre.

\section{EARLY MODEL}

The earliest of any beet in existence. It is of perfect globe shape with small tap roots. The color of the flesh is very dark red which makes it splendid for pickling purposes. In flavor it cannot be beat. It is tender, sweet and juicy, retaining its crispness throughout the season. The foliage is of a very dark color, is very small, permitting close planting of beets. This is one of the best acquisitions of recent years, Pkt. 5c; 0z. 15c; 1/4 lb. 50c; lb. $\$ 1.75$.

\section{ELECTRIC BLOOD TURNIP}

This is a carefully selected strain of this Blood Turnip Beet. It is very early, deep blood red and almost round. It is smooth and an excellent forcing variety. Good for main, spring or summer crop, and is a fine keeper. It cooks sweet and crisp and is an excellent beet in every respect. Pkt. 5c; oz. $15 \mathrm{c} ; 1 / 4 \mathrm{lb} .50 \mathrm{c} ; \mathrm{lb} . \$ 1.75$.

\section{EARLY BLOOD RED TURNIP}

This is a turnip beet, and is the old standard among the early varieites. It is of dark red color and is perhaps the most popular of all beets. Pkt. 5c; oz. 15c; $1 / 4$ lb. 45c; lb. \$1.50.

\section{EXTRA EARLY EGYPTIAN}

An extra early turnip-shaped variety; has small tops and grows quickly. The flesh is in alternate rings of white and red. Pkt. 5c; oz. 15c; $1 / 4$ lb. 45c; lb. $\$ 1.50$.

\section{DETROIT DARK RED}

A choice strain of dark red turnip beet of globular to oval shape, with smooth roots and small tops. Skin is blood red, zoned with light shades, tender and sweet. Fine for market and canning. Pkt. 5c; oz. 15c; $1 / 4$ lb. 45c; lb. $\$ 1.50$.

\section{THE LENTZ}

As early as the Egyptian, flesh very tender and sweet at all times. Very productive, a g o o d keeper and will produce crop in six weeks from time of planting. Pkt. 5c; oz. 15c; $1 / 4$ lb. 45c; lb. \$1.50.

\section{ECLIPSE}

This is as early as the Egyptian, but is more desirable owing to its globe shape, smoothness and regularity It has a small firm top, is very sweet, fine and of dark red color. Pkt. 5c: oz. 15c; $1 / 4$ lb. 45c; ob. $\$ 1.50$.

\section{CROSBY'S EARLY EGYPTIAN}

One of the earliest and best on market. It is more globular than the Early Egyptian. Especially good for market gardeners. Pkt. 5c; oz. 15c; $1 / 4 \mathrm{lb} .45 \mathrm{c}$; lb. $\$ 1.50$.

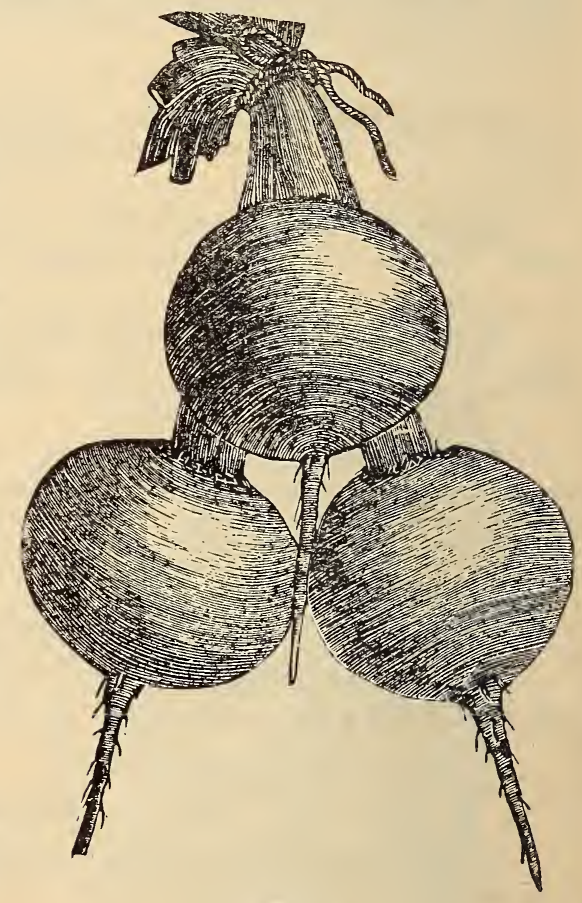

ECLIPSE

\section{ALAMO COOK BOOK' STEEL TROWEL AND GARDENERS GLOVES.}

Three excellent articles that should be in every home. The articles to make it a pleasure to work in the gardens while the cook book contains valuable topics on cooking etc. We give these FREE. See page 3. 


\section{TABLE BEETS-Continued.}

EDMOND'S BLOOD TURNIP. Handsome, round shape, skin very deep, blood red color, flesh very dark and exceedingly sweet and tender. Very regular and of good size. Irake excellent bunch beets. Pkt. 5c; oz. 15c; 1/4 lb. 45c; lb. $\$ 1.50$.

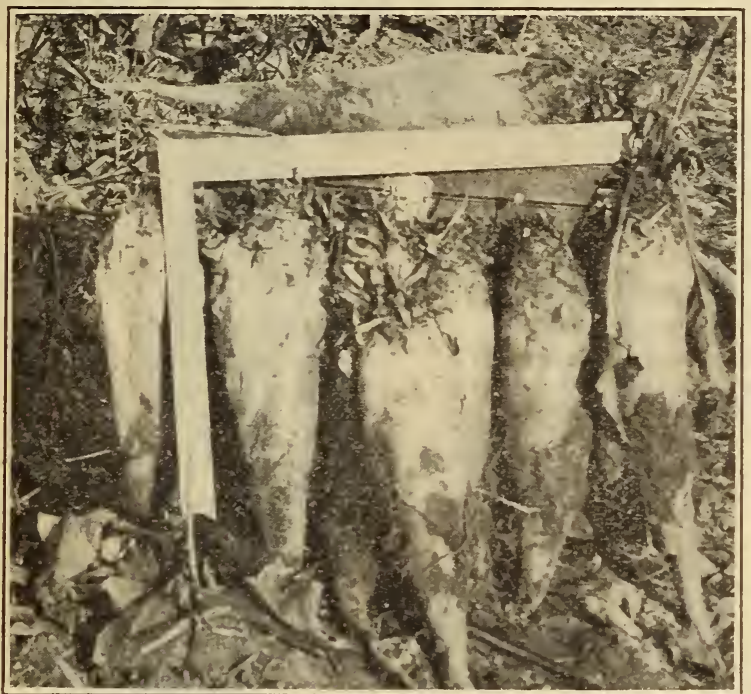

Mammoth Long Red Mangel. Asherton Texas.
HALF LONG RED. Larger than the turnip beet and makes a heavier yield. Pkt. 5c; oz. 15c $1 / 4$ lb. 45 c; lb. $\$ 1.50$.

LONG BLOOD RED. The old standard variety for table and cattle. It is the best drouth resister of all; color deep red, flesh very sweet. Grows entirely under the ground. Pkt. 5c; oz. $15 c ; 1 / 4$ lb. $45 c$; lb. $\$ 1.50$.

SWISS CHARD OR FOLIAGE BEET. This is a distinct vegetable from the common beet, much superior for greens, and is ready for use much earlier. When matured, the plant forms broad, flat and beautifully white and wax-like stems, which are very delicious when cooked as beets and asparagus tips, or pickled. We reccommend this beet. Pkt. 5c; oz. 15 c; $1 / 4$ lb. 45 c; lb. $\$ 1.75$.

\section{MANGEL AND SUGAR BEETS}

For Stock Feed these Beets bring Returns.

Every year sees an increase in the number of farmers in the south who plant a crop of Mangel or Sugar Beets for stock or feeding purposes. It is almost impossible to find crops that will give greater returns for the small amount of time and fertilizer spent on them than the Mangels, Sugar Beet and White Belgian Carrots. They are all immense yielders under good cultivation and make an agreeable change of feed for any animal kept on dry forage throughout the winter. In dairy cattle the increased flow of milk and gencrally improved condition of the animals in the spring will show their great value. Have your ground deeply plowed, then well harrowed until smooth. In the Middle South seed should be sown in the spring, but in Texas and along the Gulf Coast plantings can be made all through the fall. Make rows $21 / 2$ to 3 feet apart, planting seed at the rate of agout 6 pounds per acre. Both the Mangel and Sugar Beets are equally profitable for stock feeding. Where their value is known almost every farmer plants from one to ten pounds of seed each year, and they find that it pays them well.

\section{STOCK BEETS.}

YELLOW GLOBE MANGEL. This beet is easily pulled and more delicate than the Long Red Pkt. 5c; oz. 10c, $1 / 4$ lb. 35c; 1 lb. $\$ 1.35$.

GOLDEN TANKARD. This is a yellow beet, the most prolific variety and very nutritious. It is one of the most profitable varieties for stock feeding. Pkt. 5c, Oz. 10c; 1/4 lb. 35c; lb. \$1.25.

MAMMOTH LONG RED MANGEL. These roots attain an enormous size and it is a fine variety for feeding. Pkt. 5c, Oz. 10c; $1 / 4$ lb. 35c; lb. \$1.25.

GIANT HALF SUGAR MANGEL. This beet combines the large size of the Mangel with the great feeding value of the Sugar Beets. The flesh is white, crisp and very sweet, and the beet grows well above the ground. We recommend it especially. Pkt. 5, Oz. 10c; 1/4 lb. 35c; lb. \$1.25.

\section{SUGAR BEETS.}

WHITE KLEIN WANZLEBEN SUGAR. The beet contains 15 to 16 percent sugar, and yields under an average condition, 16 tons to the acre. It has a long slender root, and grows deeply sunk into the ground. Pkt. 5c, Oz. 10c; $1 / 4$ lb. 35c; lb. $\$ 1.25$.

LANE'S IMPERIAL SUGAR. Will yield almost as much as the best Mangel. Pkt. 5c, Oz $10 \mathrm{c} ; 1 / 4 \mathrm{lb} .35 \mathrm{c} ; \mathrm{lb} . \$ 1.25$.

SILESIAN SUGAR. The old well-known standard variety and a good beet for feeding. Pkt. 5 c, Oz. 10c; $1 / 4$ lb. 35c; lb. $\$ 1.25$. 


\section{Spargelkokl Colitior de moradu}

This plant belongs to the family of "Brassica" and is cultivated like Cabbage, Cauliflower and the other members of that family. Sow early in the spring, then transplant and set out. It will form heads like Cauliflower, but it is more hardy and of a less delicate flavor. It is grown in cold locatities to some extent, and also in the South for winter use.

PURPLE CAPE. Pkt. 10c; oz. 50c; $1 / 4$ lb. $\$ 2.00$.

LARGE WHITE MAMMOTH. Pkt. 15c; oz. 60c; $1 / 4$ lb. $\$ 2.00$.

\section{Rosenkohl \\ BRUSSELS SPROUTS \\ Col de Bruselas}

This is another member of the Cabbage f a mily. They form a straight stalk which bears on all sides a large number of miniature cabbages. These have a particularly fine flavor and are esteemed a delicacy by many. Pkt. 5c; oz. $25 \mathrm{c} ; 1 / 4$ lb. 85c; lb. $\$ 3.00$.

\section{CABBAGE.}

Choux Pomme (Fr.), Kopfkohl (Ger.), Repollo (Sp.), Cavalo Capucchio (Ital.).

CULTURE. Cabbage is sown here almost every month of the year, but the seed for the main crop should be sown from July to September. Some sow earlier, but June is time enough. For a succession seed can be sown from the end of October to the end of November, as stated before. Cabbage is a very important crop, and one of the

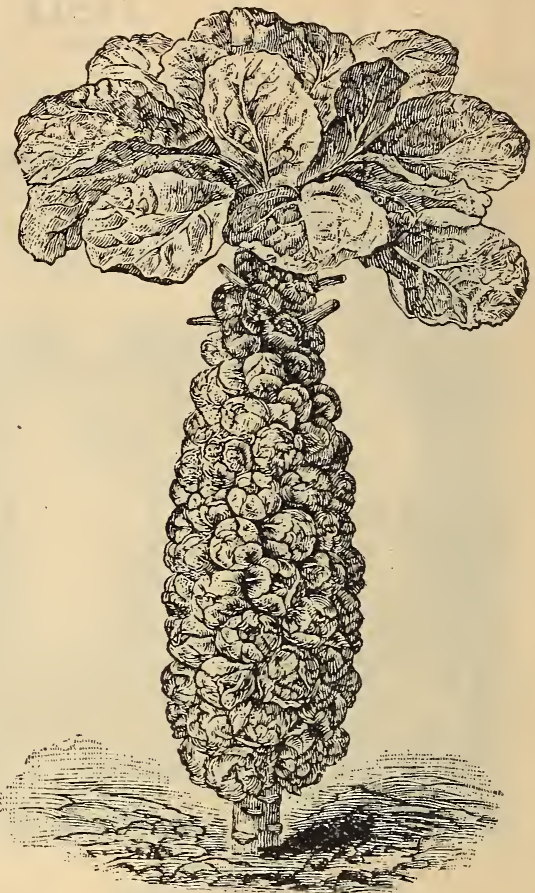

BRUSSELS SPROUTS paying for the market gardneer. It requires more work and attention than most people are willing to give and raise Cabbage plants during the months of July and August. We have found by careful observation that plants raised in August are the surest to head here. The most successful gardeners in raising cabbage plants sow the seeds thinly in seed beds, and water several times during the day; in fact, the seed bed is never allowed to get dry from the sowing of the seed till large enough to transplant. There is no danger in doing this or scalding the plants, as many would suppose, but, on the contrary, the plants thrive well, and so treated will be less liable to be attacked by cabbage flies, as they are too often disturbed during the day. Tobacco dust scattered onthe plants and in the walks between the beds is a sure preventive against insects. One ounce to 2,500 plants; $1 / 4 \mathrm{lb}$ to the acre.

VOLGA CABBAGE

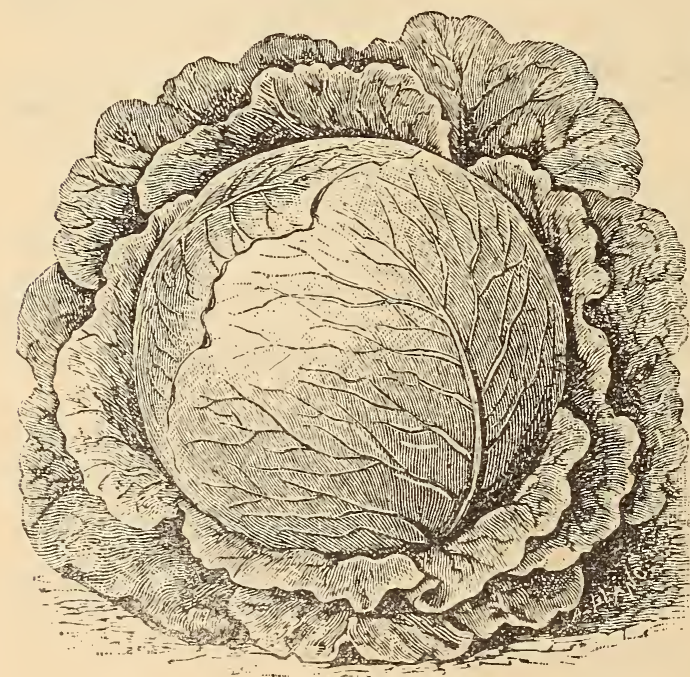

MARKET
VOLGA. The quickest $\mathrm{g} r$ o w in $g$, large late variety. Uniform in growth, head hard and solid. It is two or three weeks earlier than other large kinds. The plant is nearly all head having a few outside leaves. The heads are nearly as round as a ball and as hard and solid as Danish Ballhead, while they are much larger and heavier, of ten weighing $15 \mathrm{lbs}$. each. The quality of this Cabbage is very fine both for cooking and for kraut. Pkt. 10 c, Oz. 60c; $1 / 4$ lb. $\$ 2.25$.

\section{COPENHAGEN MARKET}

\section{(Danish grown)}

Without doubt the finest, largest, round-headed early cabbage in cultivation. The type is fixed and heads mature all at the same time. This is a big advantage to the market gardener. The heads are large, averaging about 10 pounds, are very solid and of fine flavor. It matures as early as the Wakefield and yield is much heavier. The plant is short stemmed. Color is light green. Seed from originator in Den mark. Pkt. $10 \mathrm{c} ; 1 / 2$ oz. $35 \mathrm{c} ; 1$ oz. $60 \mathrm{c}$; $1 / 4$ lb. $\$ 2.25 ; 1$ lb. $\$ 8.00$. 


\section{CABBAGE-Continued.}

EARLY SPRING. Its great value lies in its being a first early flat cabbage, a type much preferred over the pointed heads by many. It is of the "Allhead Early" type, resembling it in habit of growth, but smaller, and is nearly as early as the Wakefield. The heads have few outside leaves, and these are small and grow so close to the head that they can be planted very close together. It is round in shape, slightly flattened, very solid, even before the cabbage attain their mature size. Pkt. 10c; oz. 50c; $1 / 4$ lb. $\$ 1.75 ; 1$ lb. $\$ 6.50$.

TRUE JERSEY WAKEFIELD. This is a mos remarkable, variety, particularly adapted to the wants of market gardeners. It heads evenly from the latter part of June to the beginning of July. It is erect in growth and has cone-shaped heads. Our stock is of the true Iong Island type, and is sure to give satisfaction. Pkt. $10 c ;$ oz. 50c; $1 / 4$ lb. $\$ 1.85$; lb. $\$ 7.00$.

EARLY SUMMER. This variety is about five days later than the Wakefield, being fully double the size. In weight it is equal to most of the late varieties,

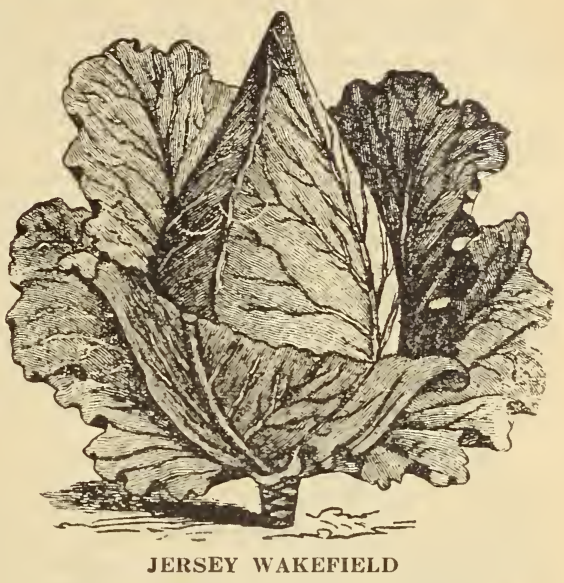
and its short outer leaves enable it to be planted nearly as close as the Wakefield. Pkt. 10c; oz. 50c: $1 / 4$ lb. $\$ 1.75 ; 1$ lb. $\$ 6.50$.

ALL SEASONS. A Drumhead cabbage as early and every way as good as Early Summer. This cabbage, while it matures a day or two later in the spring, when planted in July matures a day or earlier than Early Summer in the fall, so that it will a verage as early, while the solid heads are from a third to a half as large again, and they are as good for winter use as for summer use. Pkt, 10c; oz. 50c; $1 / 4$ lb. $\$ 1.75 ; 1$ lb. $\$ 6.50$.

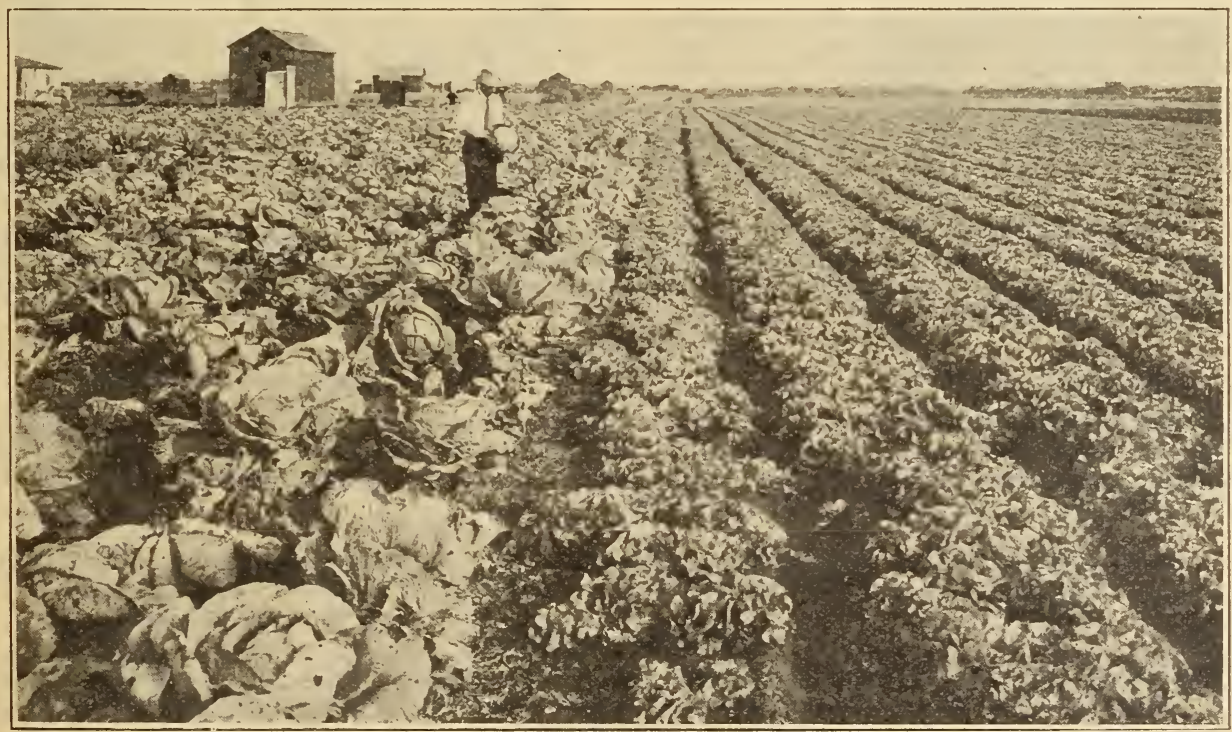

COLLINS GARDENS, SAN ANTONIO, TEXAS

USE MMOND'S SLUG SHOT FOR ALL LEAF EATING INSECTS ON ALL VEGETABLE PLANTS 


\section{CABBAGE-Continued:}

THE GLORY CABBAGE. This cabbage was recently introduced from Holland. It combined earliness with good size, qualities which are both very desirable for market purposes. This is easily one of the best sellers on the market. Pkt. 10c; oz. 50c; $1 / 4 \mathrm{lb}$. $\$ 1.75 ; 1 \mathrm{lb}$. \$6.50

ALL HEADEARLY. This is the earliest cabbage of the large early sorts and cannot be recommended too highly. It is larger than other varieties of its class and grows remarkable uniform. Pkt. 10 c; oz. 50c; $1 / 4$ lb. $\$ 1.75 ; 1$ lb. $\$ 6.50$.

THE DANISH BALLHEAD. This variety of cabbage is grown exclusively for winter use by the Dutch Gardeners, who brought it to perfection. The heads are perfectly round, extremely solid, fine grained, bear shipping well, and will keep far into the spring. It requires the full season to mature its heads alone. Pkt. 10c; oz. 50c; $1 / 4 \mathrm{lb} . \$ 1.75 ; 1 \mathrm{lb}$. \$6.50.

ST. LOUIS LATE MARKET. This variety is very popular with the krautmakers. The plant is very vigorous and hardy, the leaves are large and broad, the stem of moderate length, the head is large, white and solid and seldom bursts. Pkt. 10c; oz. 50c; $1 / 4$ lb. $\$ 1.75 ; 1$ lb. $\$ 6.50$.

SUREHEAD. It is remarkable for its certainty to head and produces large, round, flattened he ads of the Flat Dutch Type. Pkt. 10c; oz. 60c; $1 / 4$ lb. \$2.25; 1 lb. \$8.50.

EARLY DWARF FLAT DUTCH. A very popular variety because of its heat-resisting character. It never flaws under the most severe heat, and produces heads after the earliest varieties have disappeared. Pkt. 10c; oz. 50c; $1 / 4 \mathrm{lb}$. $\$ 1.75 ; 1$ lb. $\$ 6.50$.

\section{A M M O T H CHINESE C A B B A GE.}

This cabbage measures 29 inches in diameter. This cabbage does not form a head like our cabbage, but forms a loose head of very large juicy leaves. These leaves are eaten like greens and make excellent food when boiled with beef.

It requires, like all Chinese Cabbages, a rich. well-drained soil with abundant moisture. It should be sown in June or July and transplanted to open ground in August, two by two feet apart. Pkt. 10c; oz. 75c.

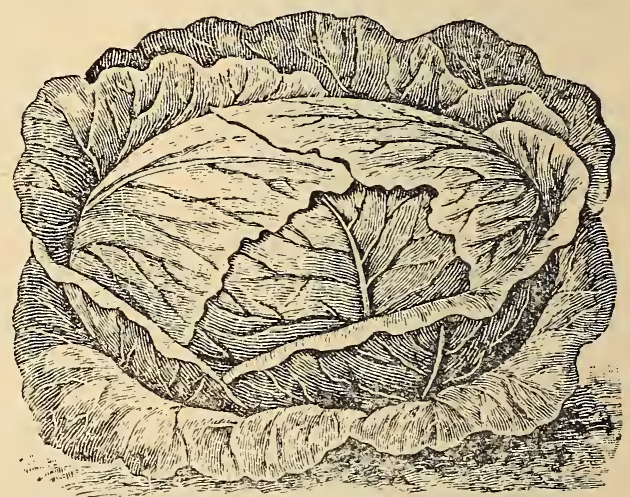

FLAT DUTCH

DANISH STONE HEAD OR ROUND RED. Produces fine round heads that are very solid and of an unusually dark purple color. The rich coloring extends to the center of the head and a crosssection shows but very little white. Pkt. 10c; oz. 50c, $1 / 4 \mathrm{lb}$. 1.75c; $1 \mathrm{lb}$. $\$ 6.50$

MAMMOTH RED ROCK. This is by far the largest and surest heading red cabbage ever introduced. The plants are large with numerous spreading leaves. The head is large, round, very solid, and of a deep red color. Ninety-eight per cent of the plants will form extra fine heads. Pkt. 10c; oz. 50c $1 / 4$ lb. $\$ 1.75 ; 1$ lb. $\$ 6.50$.

\section{Wirsing}

\section{SAVOY CABBAGE}

DRUMHEAD SAVOY. An excellent winter and spring family cabbage, partaking partially of the size of the Drumbead and the curled leaves of the Savoy. Market gardeners usually find it profitable to provide a limited quantity for discriminating customers; for family use it is equalled by none. Pkt. 10c; oz. 50c; $1 / 4$ bl. \$1.75: 1 lb. \$6.50.

CABBAGE PLANTS. We can furnish Cabbage and Cauliflower Plants about September. If you are interested, write us for the names and prices of the varieites grown by us.

\section{SPECIAL NOTICE}

Our seeds are all tested by our Grower before being shipped to us, and immediately upon their arrival here they are tested in the Standard Seed Tester and in the ground, thereby assuring perfect germination. It is to our interest to sell the very best seed obtainable.

Our facilities are without doubt the very best in the South, and, coupled with our many years of experience, afford us the opportunity to get the very best that is grown.

The above are facts, and while we could write pages of proofs of our method of doing business, it is useless for us to burden you with length write-ups when a trial order from you will convince you and let you prove it for yourself. 


\section{CARROTS.}

Carrotte (Fr.), Noehre or Gelbe Ruebe (Ger.), Zanahoria (Sp.), Carota (Ital.).

CULTURE. Requires a sandy loam, well manured the previous year, and deply spaded up. Should be sown in drills ten to twelve inches apart, so that the plants can be worked after they are up. Gardeners here generally sow them broadcast, and of ten the roots are small from being crowded too much together. This is a deep rooted crop and ground should be well broken and the soil prepared deep enough to allow the plants to penetrate. One ounce to 250 feet of drill; $2 \frac{1}{2}$ pounds per acre.

\section{TABLE USE}

EXTRA EARLY SHORT FORCING. An excellent forcing variety; very tender, small tops, and of fine flavor. Pkt. $5 \mathrm{c}$; oz. $15 \mathrm{c} ; 1 / 4 \mathrm{lb} .50 \mathrm{c} ; 1 \mathrm{lb}$. $\$ 1.50$.

EARLY SCARLET HORN. A very early variety. Recommended for the market and home garden. Texture very fine and very delicate in flavor. Pkt. 5c; oz. 15c; $1 / 4 \mathrm{lb} .50 \mathrm{c} ; 1 \mathrm{lb}$. $\$ 1.50$.

OXHEART OR GUERNADE• The French Carrot is one of the most valuable varieties either for family use or for the market. It is an intermediate between the half long and the Horn types attaining a diameter of 3 to 4 inches at the neck. It is very productive, rich orange color and beautiful shape. Pkt. 5c; oz. 15c; $1 / 4$ lb. 50c; 1 lb. $\$ 1.50$.

CHATENAY OR MODEL. A. nice smooth carrot of perfect and uniform shape. A heary yielder, a fine table quality 5 to $h$ inches long and easily dug. The flesh is of a deep yellow color. tender and of excellent flavor. Pkt. 5c; oz. 15c; $1 / 4$ lb. 50c; 1 lb. $\$ 1.50$.

If you want reliable seed come to us. If you just want seed go to the other fellow.

DANVERS HALF LONG. Admirable in color, fixed in habit, a wonderful producer, the best of all for the stock breeder, and valuable to the market gardener. With the variety the planters secure the largest return to the acre, with the least difficulty of harvesting. Pkt. 5c; oz. 15c; $1 / 4$ lb. 50c; 1 lb. $\$ 1.50$.

HALF LONG SCARLET NANTES. Foliage finely cut, dark and of medium height, roots slender, smooth, and of a bright orange color, flesh orange becoming yellow towards the center, but with no distinct core. Quality very fine. Pkt. 5c; oz. 15c; $1 / 4 \mathrm{lb} .50 \mathrm{c}$; $1 \mathrm{lb} . \$ 1.50$.

\section{STOCK FEEDING}

Fur Futterzwecke
IMPROVED LONG ORANGE. The old Standby, for

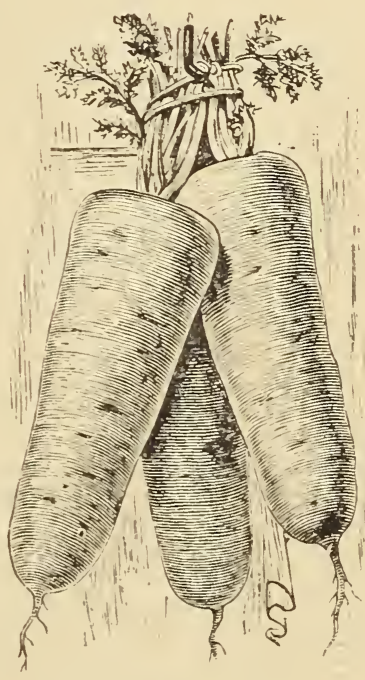

CHANTENAI

both stock feeding and table use, either summer or winter. Fed to milch cows, it increases the flow of rich milk and gives to the butter a fine flavor and a beautiful color. Pkt. 5c;oz. 15c; $1 / 4 \mathrm{lb} 50 \mathrm{c} ; 1 \mathrm{lb}$. $\$ 1.50$.

LARGE WHITE BELGIAN. Grows one-third out of the ground. Root pure white, green above the ground and has a small top. It will grow to a very large size on rich soil, and is very easily gathered. Flesh rather coarse and used exclusively for stock feeding purposes. Pkt. 5c; oz. 10c; 1/ Ib. $30 \mathrm{c} ; 1$ lb. $\$ 1.00$.

LARGE YELLOW BELGIAN. Practically the same as the above, except that the color of the flesh is yellow. An excellent keeper. Pkt. 5c; oz. 10c; $1 / 4 \mathrm{lb} .30 \mathrm{c} ; 1 \mathrm{lb} . \$ 1.00$.

\section{"HAMMONDS SLUG SHOT." USED FROM OCEAN TO OCEAN.}

CABBAGE WORMS. The Cabbage Worm has spread wherever cabbage is grown. Whether early cabbage or late cabbage, in garden or field, it perforates the plant, and is of all worms one of the most disgusting, to find hidden away in the folds of the leaf. If you want Cabbage free from Worms, use Hammond's Slug Shot.

How to destroy Cabbage Worms. Slug Shot can be used lightly or heavily and the cabbage suffers no harm. The cabbage forms its head by the interior growth: it throws off its earlier and outside leaves, and no dust can enfold within its head. Apply Slug Shot with a Duster, sieve it over the plants or full grown cabbages. The powder is very fine and goes a long way in field or garden. 
Blumenkohl.

CAULIFLOWER.

Coliflor.

CULTURE. The same as for Cahbage, except that it will pay to use extra manure and plenty of water for Cauliflower. If the soil is dry water frequently and if the plants have a heavy mulch of hay or straw, it would keep the soil moist, and the plants would not suffer from drouth. The early kind should be strong enough to plant out not later than the middle of August; the late kinds may be planted out the same as Cabbage. One ounce of seed produces 1,500 plants; 15,:000 plants will cover one acre.

\section{EARLY DANISH SNOWBALL.}

This splendid Cauliflower is extremely early, heads with certainty and these heads are of high quality. The plant is dwarf, outer leaves are erect, while the inner leaves lap over the head, protecting it from the sun. It is the finest Cauliflower on the market, and we recommend it to the Market Gardeners especially. Pkt. 25c; $1 / 4$ oz. $\$ 1.00 ;$ oz. $\$ 3.00 ; 1 / 4 \mathrm{lb}$. $\$ 10.00$.

EXTRA EARLY DWARF ERFURT, SELECTED. This is the choicest strain of the popular Erfurt type and noted for its extreme reliability in heading. Plants are very dwarf with solid, pure white heads of excellent quality. When planted in rich soil early in the spring, heads 8 to 10 inches in diameter can be marketed in July. Pkt $25 \mathrm{c} ; 1 / 4$ oz. $\$ 1.00$; oz. $\$ .3 .001 / 4$ lb. $\$ 10.00$.

EARLY PARIS. An excellent French variety, and very popular among the early sorts in the Paris markets. Heads are large, white, compact, solid, of excellent flavor, tender and delicious. Leaves large, stalk short. Pkt. $15 \mathrm{c} ; 1 / 4$ oz. 50c; oz. $\$ 1.751 / 4$ lb. $\$ 6.00$.

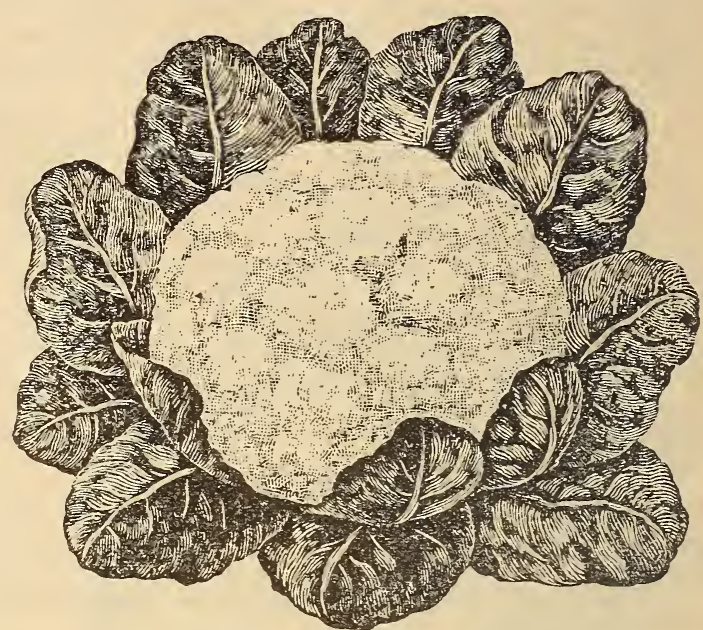

DANISH SNOWBALL

CULTURE. For early celery sow in March or February, in hot beds, in drills 4 to 5 inches apart and cover about $1 / 4$ inch deep. When fairly out of seed leaf transplant to another bed, thin out to 2 to 3 inches in the row, and leave growing until needed to plant outside. In April plant the field rows 18 to 20 inches apart, and set six inches in the row. In planting press the ground around the plants but do not let any earth get into the heart. The soil should be very rich and the plants should be earthed up several times during their growth. Celery needs more water than any other garden crops, and is liable to get sof $t$ if not watered sufficiently.

For winter use sow the seed in the latter part of April, or beginning of May, in beds, and transplant in the fields in July. If the roots are to be dug up and put in trenches to bleach, allow two feet between the rows, or if they are to bleach in the same place where grown, allow four feet. When cold weather sets in dig a trench in a high well drained place, one foot wide, and of a depth of a few inches less than the height of the celery. Set your plants closely in it and cover gradually with straw or hay and earth as the weather gets colder. The top of the trench should be sloping so as to allow the water to run off. One ounce of seed produces 2,500 plants and it takes about 42,000 plants to set one acre if the rows are 2 feet apart.

WHITE PLUME. This celery is valued because the stalks and portions of the inner leaves and heart are white, by simply tying up the stalks and drawing up the soil with the hoe, the work of blanching completed. It is ornamental, tender, crisp and of good flavor and very early. Pkt. 5c; oz. 25c; $1 / 4$ lb. $75 \mathrm{c} ; 1$ lb. $\$ 2.50$.

GIANT PASCAL. This is a green leaved variety. It bleaches very quickly after earthing up and is a beautiful yellowish white color, very solid and crisp, and of a sweet flavor which is not equalled by any other variety. The stalks grow broad and thick, a single plant making a large bunch. Under high cultivation this variety will give the best satisfartion. Pkt. 5c; oz. 35c; $1 / 4$ lb. $\$ 1.00: 1$ lb. $\$ 3.50$.

GOLDEN SELF BLANCHING. This is a beautiful plant of close habit, compact growth, and has straight and vigorous stalks. The ribs are perfectly solid, crisp and brittle. Its delicate flavor is surpassed by no other variety and moreover it has the decided merit of being self-blanching to a very remarkable degree. Our stock of this seed is selected with special care in France.

AMERICAN. Pkt. 5c; $1 / 2$ oz. 20c; oz. 35c; $1 / 4$ lb. $\$ 1.50 ; 1$ lb. $\$ 4.00$.

FRENCH. Pkt. 5c; $1 / 2$ oz. 60c; oz. $\$ 1.10 ; 1 / 4$ lb. $\$ 4.00$.

CELERIAC OR TURNIP-ROOTED CELERY. Grown exclusively for its roots, which are turnip shaped, very smooth, tender, and marrowlike. The roots are cooked and sliced and eaten with vinegar. They make an excellent salad. Are used for seasoning meats and flavoring soups. Pkt. 5c; oz. 35c; $1 / 4$ lb. $\$ 1.00$.

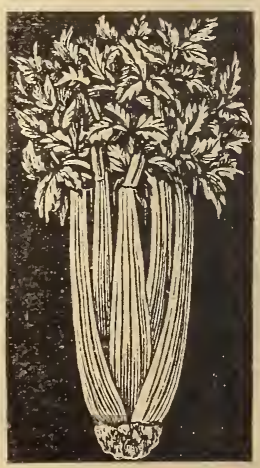

CELERY FOR PROFIT. By Griener. Illustrated. Price 50c. 


\section{WITLOOF CHICORY}

FRENCH ENDIVE. A few years ago this salad vegetable was almost unknown in America. It is now on the bill of fare of all first-class restaurants. Although mostly imported as yet, it is an easily grown winter vegetable which can be raised in every home.

We have many customers that are growing it successfully and are very enthusiastic about it, for it furnishes a delicious salad in winter when other fresh vegetables are not a vailable.

Plant seed in March or April. Lift the roots in November or December, and store in sand in a cool place until ready for starting into growth in soil in the cellar.

Forcing or growing is done any time from December 15, until spring, in good soil in cellars, not beds or outdoors. Pkt. 10c; oz. 30c; $1 / 4$ lb. $\$ 1.00 ; 1$ lb. $\$ 3.00$.

\section{Cichorienwurzel.}

\section{CHICORY}

\section{LARGE ROOTED OR COFFEE}

Achicoria.

A hardy plant introduced from and much used in Europe as a substitute for coffee; large quantities of prepared roots are exported to this country. May be used to good advantage and pay large profit, and its culture is simple. In the fall the roots require to be taken up and cut into small pieces and put where they will dry requiring the same treatment used for drying apples. When required for use they should be roasted and ground like coffee. Required similar treatment as carrots. Pkt. 5c; oz. $15 \mathrm{c} ; 1 / 4 \mathrm{lb} .50 \mathrm{c} ; \mathrm{lb} . \$ 1.50$.

\section{COLLARDS}

\section{GEORGIA SOUTHERN OR CREOLE}

This is the variety so extensively used in the South, where it furnishes an abundance of food for both man and beast. Forıns a large, loose, open head, or a mass of leaves on a tall stem. Freezing improves the quality. Pkt. 5c; oz. 15c; $1 / 1$ 1b. 50c;

Stechsalas.

\section{CORN SALAD}

\section{BROAD LEAVED}

\section{Macha o Valerinailla.}

Used as a small salad throughout the winter and spring. Sow thickly in drills, cover slightly at the beginning of autumn and sprinkle with straw on the approach of severe winter weather, or sow in a cold frame, covered in winter as may be convenient-thus is accessible even when the deep snow prevails. Pkt. 5c; oz. $15 \mathrm{c} ; 1 / 1 \mathrm{lb} .50 \mathrm{c}$.

Schnittlauch.

\section{CHIVES}

The Chives are small and not very important members of the onion tribe, quite hardy everywhere. The leaves are slender and appear very early in the spring, and may be cut several times during the season. They are propagated by seeds and by roots. The Chives make the very best border for beds in the begetable garden, and are not only useful, but bearing pink flowers and a mass of golden leaves, are ornamental and are equal to the onion for flavoring soups and salads. Pkt. 10c; oz. 60c; Roots 20c per bunch, 3 for 55c. postpaid.

Kresse.

\section{CRESS}

Used as a small sald. Sow very thickly in shallow drills; cover on a smooth surface at short intervals throughout the season. Pkt. $5 \mathrm{c} ;$ oz. $10 \mathrm{c} ; 1 / 4 \mathrm{lb} .35 \mathrm{c} ; 1 \mathrm{lb} . \$ 1.00$

Brunnen Kresse.

\section{WATER CRESS}

Is quite distinct from garden cress, and thrives only when its roots and stems are submerged in water. It is one of the most delicious of small salads and should be planted wherever a suitable place can be found. Pkt. $10 \mathrm{c} ;$ oz. $75 \mathrm{c} ; 1 / 4$ lb. $\$ 2.25$.

\section{POP CORN}

WHITE PEARL. A common variety having smooth kernels. Pkt. 10c; 1b. 25c.

\section{WHITE RICE}

A very handsome variety; kernels long, pointed, resembling rice. Very prolific, and fine for parching. Does not pop as large as Queen's Golden, but is more tender and better flavor. Pkt. 10c; $1 \mathrm{lb} .25 \mathrm{c}$.

\section{QUEEN'S GOLDEN}

Produces ears in great abundance on stalks nearly six feet high. It pops perfectly white. A single kernel will expand to nearly an inch in diameter. Pkt. 10c; 1b. 25c. Postage 5c.

\section{BLACK BEAUTY POP CORN}

A distinct variety obtained by crossing the old Indian Squaw Corn with White Rice Pop Corn. The kernel is black, but when popped is nice and white. Black Beauty matures early and is ready for popping before other varieties. Pops very large and is very tender. Pkt. 10c. 1/2 lb. 15c; lb. 25c; Write for prices on large quantities. 


\section{Speise Mai.s}

\section{SWEET CORN.}

Use regular parcel post chart when ordering corn by mail. One pound is equal to over threefourths of a quart. See page 2 .

CULTURE. All varieties of sweet corn may be sown either in rows four feet apart and the seeds planted about eight inches in the row, or planted in hills at a distance of three or four feet each way according to the variety grown or the richness of the soil in which it is planted. Sweet Corn should not be planted deeper than one to one and a half inches, as it is liable to rot in the ground. Hoe of ten, drawing the earth against the stems and breaking off the side shoots. One pound to 25 hills. About one-fourth bushel will plant one acre in drills.

GOLDEN BANTAM. Is the most tender, sweetest, richest, and best evergreen Sweet Corn in existence. It produces strong, sturdy stalks, growing about four feet high Is extremely hardy and can be grown from the Gulf to the Great Lakes. Each stalk produces three to four fine ears 5 to 6 inches long, having eight rows of sweet kernels. Golden Bantam is the quickest to mature and will give better and quicker results than any other sweet corn we know of. We have found it remarkably free of worms. Don't fail to have some of this splendid corn in your garden next year. pkt. 10c; 1b. 30c; 2 lb. 55c; 10 lbs. \$2.50.

EXTRA EARLY ADAMS. This is not a true sweet corn, but on account of its hardiness and its round, hard grains it can be planted much earlier than the wrinkled sort sugar corn. The ears are well filled with tender white kernels. It is usually ready a week earlier than the Cory.

Pkt. 10c; 1 lb. 20c; 2 lbs. 35c; 10 lbs. \$1.50.

WHITE MEXICAN. This new variety of recent introduction is 4 to 5 days earlier than the White Cob Cory and has all the delicious sweetness of Black Mexican. Pkt. $10 \mathrm{c} ; 1$ lb. $25 \mathrm{c} ; 2$ lbs. $45 \mathrm{c} ; 10$ lbs. $\$ 2.00$.

EARLY MINNESOTA. This is among the earlies ${ }^{t}$ of the sugar varieties, and is much esteemed, not only because it matures earlier, but because of its excellent qualities as well. Ears rather small, long and pointed. Pkt. 10c; 1. lb. $25 \mathrm{c} ; 2$ lbs. $45 \mathrm{c} ; 10$ lbs. $\$ 2.00$.

EARLY EVERGREEN. Like Stowell's Evergreen, only ten days earlier. Ears large, about 18 inches long, 12 to 16 rowed, and having the identical flavor of the famous Stowell's Evergreen. Pkt. 10c; 1b. 25c; 2 lbs. 45c; 10 lbs. $\$ 2.00$.

BLACK MEXICAN. The sweetest and most desirable for family use. When dry the kernels are black. Pkt. 10c; 1 lb. 30c; 2 lbs. 55c; 10 lbs. $\$ 2.50$.

STOWELL'S EVERGREEN. This variety is more largely planted than any other, and is the general favorite with canners and market gradeners for late use. It is very productive, the ears are of large size, grains, deep, exceptionally tender and sugary and remain for a long time in an edible condition. Pkt. 5c; 1 lb. 30c; 2 lbs. 55c; 10 lbs. \$2.50.

COUNTRY GENTLEMAN. The ears are not only of good size, but are produced in great abundance, one stalk frequently bearing four good ears while the average is three to a stalk. The cnb is very small giving great depth to the kernels, whidh are of pearly whiteness. Pkt. 10c; $1 \mathrm{lb}$. 30c; 2 lbs. 55c; 10 lbs. $\$ 2.50$.

HASTINGS' PROLIFIC. Not a sweet corn but a good corn for roasting ears. Hastings' Prolific Corn is a wonder in production of both grain and forage. 'Tt is the most prolific corn we have ever seen, the yield of grain and forage being enormous. It makes more ears and better ears, with longer, deper grains. Hastings' Prolific averages 16 to 18 rows. It has deep grains very closely set on a very small white cob. Sixty-five pounds of corn in the ear shells out one bushel or more. Grains rather flinty and a good keeper. Medium early, maturing in from 110 to 120 days. Makes splendid "roasting ears," the size of ears being good, and in flavor almost equal to that superb variety of Sweet Corn "Country Gentleman." It is the best all purpose corn that you can grow in the South. It pays as a field crop; it pays the market gardener; it pays in the home garden. It roots deeply, resisting drought and storms. It is adapted to both upland and lowland. It always makes a crop and is a prize winner at the crib of every man who plants it. Lb. 15c. 
Gurken.

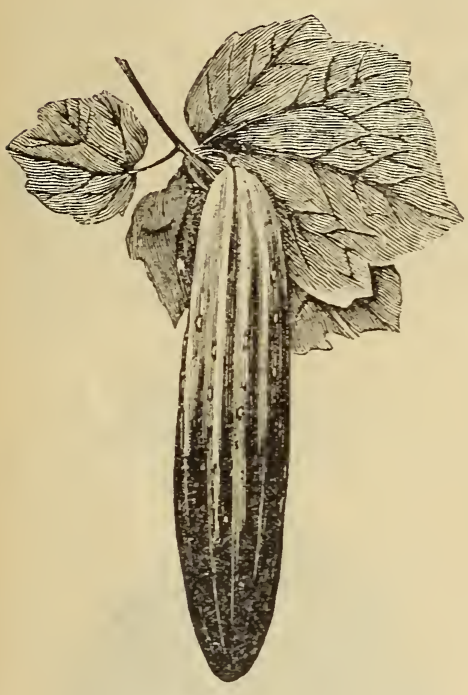

LONG GREEN

\section{CUCUMBERS.}

CULTURE. For early, sow seed in hotbed in small pots and plant out when danger of frost is over. They can be marketed with a gain of six or seven weeks over those sown in the open ground. For general crops drop in hills four to six feet apart, as soon as the weather is warm, ten to twelve seeds in a hill, cover half an inch deep and pat it down with a hoe. Hoe often, and when out of danger of insects, thin out to three or four plants to a hill. Middle of March to April 1st is the right time to sow for pickles. Pick fruits as soon as big enough to use or the productiveness will be injured. One ounce will plant about 50 hills. One pound to one acre.

IMPROVED LONG GREEN. This is unquestionably the most popular for general use. When matured is 9 to 12 inches long. Flesh is very solid, crisp and of delicate flavor. The skin is dark green and retains its color for a remarkable lorig time. Pkt. 5c; oz. 15c; $1 / 4$ lb. 50c; 1 lb. \$1.50.

DAIIS PERFECT. This is one of the very best cucumbers grown, both for forcing and for out of doors. It is slim and symmetrical in shape and from 9 to 12 inches long and of a dark, glossy green color changing to white, without streak of yellow, only when ripe. Pkt. 5c; oz. 15c; $1 / \frac{1}{t}$ bl. 50c; 1 lb. \$1.50.

COOL AND CRISP. A popular, extremely early variety of the White spine type. Very prolific and produces large numbers of medium sized cucumbers, excellent for table use. The fruit is six to eight inches long, distinctly tapering with a dark skin thickly set with small knots. Pkt. 5c; oz. 15c; $1 / 4 \mathrm{lb}$. $40 \mathrm{c} ; 1$ lb. $\$ 1.25$.

EARLY WHITE SPINE. Vines vigorous, bearing early and abundantly. Fruit uniformly straight and handsome, dark green, with a few white spines. Flesh tender and of excellent flavor. ['sed extensively for forcing under glass. Pkt. 5c; oz. 15c; $1 / 4$ lb. 40c; 1 lb. $\$ 1.25$.

EVERBEARING. This variety is of small size. very early, enormously productive, and valuable as a green pickle. Pkt. 5c; oz. 15c; $1 / 4$ lb. $40 \mathrm{c} ; 1$ lb. $\$ 1.25$.

LEMON CUCUMBER. Here is a cucumber in the shape of a lemon, and having a flavor that at once puts it ahead of the common cucumber. It is bound to become a great favorite as a table delicacy. It is an excellent shipper, and pickled as a gherkin, is delicious. Pkt. 10c; oz. $20 \mathrm{c} ; 1 / 4$ lb. $70 \mathrm{c} ; 1 \mathrm{lb} . \$ 2.00$.

EARLY GREEN CLUSTER. A very popular early cucumber producing its fruit in small clusters near the root of the plant. Average length is about 5 inches, skin prickly, flesh white, seedy, tender and well flavored. Pkt. 5c; oz. 15c; $1 / 4$ lb. 40c; 1 lb. $\$ 1.25$.

ARLINGTON WHITE SPINE. This is the strain so popular in Chicago for growing under glass. Pkt. 5c; oz. 15c; $1 / 4 \mathrm{lb} .40 \mathrm{c}$; 1 lb. $\$ 1.25$.

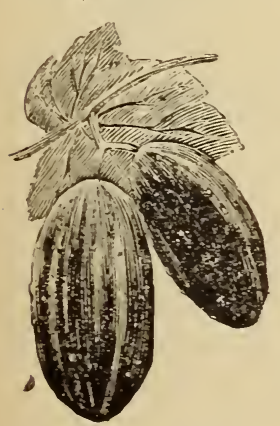

SHORT PROLIFIC

KLONDYKE. An attractive dark green cucumber, averaging 6 to 7 inches long and 2 inches thick; of unsurpassed quality. Its points of superiority are: Extreme earliness, a prolific bearer, very hardy; size just right for a slicing cucumber. An excellent pickling sort. Pkt. $5 \mathrm{c}$; oz. $15 \mathrm{c} ; 1 / 4 \mathrm{lb} .40 \mathrm{c} ; 1 \mathrm{lb} . \$ 1.25$.

BOSTON PICKLING. The fruit abundantly borne, averages 4 to 5 inches in length and is of excellent quality. Pkt. 5c; oz. 15c;1 1/ lb. 40c;1 lb.\$1.25.

JAPANESE CLIMBING. While all cucumbers are running vines, this variety is much more so than others. It climbs quickly on poles or trellises and is entirely distinct. The quality is splendid and well adapted for pickling and salads. The greatest advantage of having a cucumber trained on a pole or fence is evident. Pkt. 5c; oz. $15 \mathrm{c} ; 1 / 4$ bl. $40 \mathrm{c} ; 1 \mathrm{lb} . \$ 1.25$.

WEST INDIA GHERKIN. The fruit is very small, almost round and closely covered with spines. Pkt. 5c; oz. $20 \mathrm{c} ; 1 / 4 \mathrm{lb} .50 \mathrm{c} ; 1 \mathrm{lb} . \$ 1.50$.

SHORT PROLIFIC. A very short variety of the "Frame" type. It is a abundant bearer, and is highly recommended for pickles, for which it is used extensively in New York State. Pkt. 5c; oz. 15c; $1 / 4$ lb. 40c; 1 lb. \$1.25. 
Endiven.

ENDIVE

Escaroly e Endibia.

CULTURE. The same as lettuce.

A desirable salad. When bleached by exclusion of the sun, gather all the leaves and tie them'for a couple of days. Open after a rain to give them a chance to dry out, as otherwise the leaves begin to rot. The inside will turn into a beautiful yellowish green, making the plant very attractive for salads and garnishing.

GREEN CURLED. The hardy variety. Pkt. 5c; oz. 15c; 1/4 lb. 50c; lb. \$1.50.

BROAD LEAVED BATAVIAN. Very thick leaved. Pkt. 5c; oz. 15c; $1 / 4$ lb. 50c; lb. $\$ 1.50$.

MOSS CURLED. Plants compact, large leaves, green and finely divided. Pkt. 5c; oz. 15c; $1 / 4$ lb. 50c. lb. $\$ 1.50$.

Eierpflanze.

EGG PLANT

Berenjena.

CULTURE. Sow in hot beds very early in the spring; thin them out as soon as big enough to be handled to 3 or 4 inches each way, and transplant to 2 or 3 feet apart in very rich warm ground. Do not plant them outside till nights are real warm, as the least frost will, if it does not kill them, check the growth, and it will take 2 or 3 weeks before they get over it. Hoe often and hill up gradually till they blossom. One ounce to 1,500 plants.

BLACK BEAUTY EGG PLANT. The earliest large fruited variety. The fruits set freely and develop quickly so the entire crop can be harvested before frost. They are large, thick, and of a rich lustrous purplish black. The calyx is entirely free from spines or thorns. Pkt. 10c; $1 / 2$ oz. $40 \mathrm{c}$; oz. $75 \mathrm{c} ; 1 / 4 \mathrm{lb}$. $\$ 2.25$.

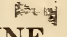

NEW YORK IMPROVED LARGE PURPLE SPINELESS. This variety has about superseded all others both for market and home garden; a favorite everywhere. Our stock is extra selected direct from the best growers in New Jersey. Pkt. 10c; $1 / 4$ oz. 15c; oz. 50c; $1 / 4$ lb. $\$ 1.75$.

EARLY LONG PURPLE. This is the earliest variety, very hardy and productive; fruit long and of superior quality. Pkt. 10c; $1 / 4$ oz. 15c; oz. $45 \mathrm{c} ; 1 / 4$ lb. $\$ 1.60$.

\section{Knoblauch.}

\section{GARLIC}

The garlic is the most pungent of all the onion family. It is much used in the south of Europe. The root, or bulb, is composed of many small bulbs called "cloves," which are planted in the spring 6 to 8 inches apart, and in August the bulbs are ready to gather. Write for prices on large lots. Lb. 25c.

\section{HORSE RADISH}

\section{Meerrettig.} of the root.

\section{Rabano Rustico.}

\section{NEW BOHEMIAN HORSE RADISH tMALINER KREN.}

The Maliner Kren Radish Roots were introduced by he U. S. Department of Agriculture. They are much earlier and produce better than the ordinary sort. The roots grow larger, are white, and quality is far superior. All who grow Horse Radish should try this variety. Dozen 25c; 50 for 70c; 100 for $\$ 1.25$. postpaid.

CULTURE. For late fall and winter use it should be sown from the end of July till the middle of October, for spring use, during January and February.

EARLY WHITE VIENNA. The earliest and best for forcing. Pkt. 5c; oz. $25 \mathrm{c} ; 1 / 4$ lb. $75 \mathrm{c}$.

EARLY PURPLE VIENNA. Both Vienna Kohlrabis are very tender and excellent for table use. Plkt. 5c; oz. 25c; $1 / 4 \mathrm{lb}$. 75c.

\section{KALE OR BORECOLE}

Krauskohl oder Blatterkohl.

DWARF GREEN GERMAN. Sow in the spring for "sprouts" or "grteens." Hardy, prolific, flavor similar to cabbage; desirable in every garden. Pk., 5c; oz. 20c; $1 / 4$ lb. 50c; lb $\$ 1.75$.

TALL GREEN CURLED OR SCOTCH. This is one of the most popular varieites. It is very hardy and is much improved by frost. Two J eet high. Pkt. 5c; oz. 20c; $1 / 4$ lb. 60c; lb. $\$ 2.00$.

Porree oder Lauch. LEEK

CULTURE. A hardy species of onion, sown in drills or broadcast. When 6 inches high transplant into rows a foot apart, setting the plants 4 or 5 inches deep and about 6 inches apart in the row. Used mostly in soups and

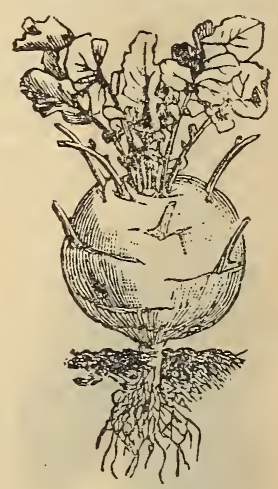

KOHLRABI stews. One ounce to 1,000 plants.

LARGE LONDON OR SCOTCH FLAG. This leek aside from being valuable for soups and salads, when blanched, makes an excellent dish if sliced and cooked. Pkt. 5c; oz. 25c; 1/4 lb. 80c; lb. $\$ 3.00$. 


\section{LETTUCE}

Laiture (Fr.), Lattich (Ger.), Lechuga (Sp.), Lattuga (Ital.),

CULTURE. Lettuce is sown here during the whole year by the market gardeners. Of course' it takes a great deal of labor to produce this vegeatble during our hot months. Before sowing soak the seeds for two hours in water, take them out, put in a piece of cloth and set in a cool damp place. or if convenient in an ice box, which is best. Keep the cloth moist and in four to six days the seeds will sprout. Then sow them. It is best to do so in the evening, and give a good watering. If the seeds are sown without being sprouted, ants will be likely to carry them away before they can germinate, a nd the seedsman be blamed for selling seeds that did not grown. This sprouting has to be done from May to September, or, if the weather is warm and dry in the latter month, up to the middle of October. Should the weather be moist and cool in the Fall, it can be dispensed with. The richer and better the ground the larger the head will be. The seed should be sown broadcast; when large enough plant out foot apart, and from eight to ten inches apart in rows. One ounce to 250 feet of drill; 3 pounds pe $r$ acre.

\section{EARLY AND FORCING VARIETIES}

BIG BOSTON. This variety resembles the well known Boston Market but produces heads almost double the size and mature a week later. Endures hot weather exceedingly well. Pkt. 5c; oz. 15c; $1 / 1$ lb. 50c; lb. \$1.50.

WHITE SEEDED TENNIS BALL. One of the best varieties of headed cabbage lettuce for growing under glass. Very hardy, with thick, crisp, and tender leaves. Forms a compact head under glass, but unless planted very early is apt to be loose in the open air. Pkt. 5c; oz. 15c; $1 / 1$ 1b. 40c; lb. $\$ 1.25$.

GRAND RAPIDS. For greenhouse forcing this variety has few equals. It is of quick growth, little liable to rot and can stand some days after being out. The plant is upright and forms a loose head or cluster of large rellowish

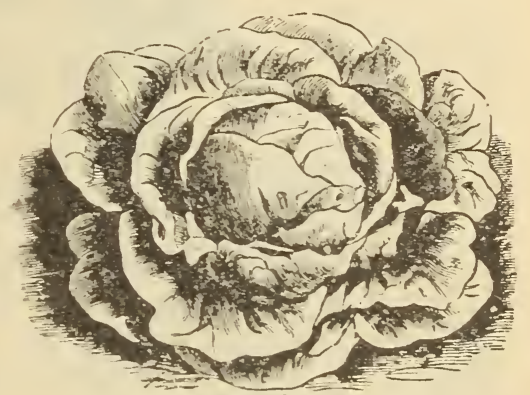

BIG BOSTON green leaves which are slightly crimped, blistered and ratherthin. Is a good shipper. Pkt. 5c; oz. 15c; $1 / 4$ lb. 40c; lb. $\$ 1.25$.

MAY KING. The best Butterhead lettuce for forcing as well as early. It is extremely hardy and therefore can be planted very early in the spring. It makes a quick growth, forming, when mature, attractive heads measuring 10 to 20 inches across. The outside leaves are tightly folded, making the plant practically all head. It has a rich buttery flavor which is delicious. We recommend it particularly to Market Gardeners, as the tightly folded heads carry well, and will out-sell any other. Pkt. $5 \mathrm{c} ;$ oz. $15 \mathrm{c} ; 1 / \frac{1}{4}$ lb. $40 \mathrm{c}$; lb. $\$ 1.25$.

\section{LOS ANGELES LETTUCE}

One of the best varieties for main crop. When the few outside leaves are stripped off, there remains a shapely head as hard and large as a small cabbage with interior yellowish white, crisp and tender. Pkt. 5c; oz. 20c; $1 / 4$ lb. 60c; lb. $\$ 1.75$.

\section{CALIFORNIA CREAM BUTTER}

Heads large, round and of a beautiful appearance. The outer leaves are glossy green, masked with small brown spots; the inner leaves are of a rich color. Medium early, and makes a good sort for summer use. Quality is very good. Pkt. 5c; oz. 15c; 1/4 lb. 40c; lb. $\$ 1.25$.

\section{LOOSE-HEAD OR CUTTING VARIETIES}

The best of these is the Black Seeded Simpson. It produces even larger bunches of leaves than the popular Curled or Silesia Curled Simpson, and remains in good condition longer before running to seed. For late summer use, after the season for head lettuce is passed, we wold especially recommend the Early Prizehead. This variety forms large, loose heads, with finely curled leaves lightly tinged with brown. It grows to large size and will stand for a considerable time before running to seed.

BLACK SEEDED SIMPSON. Good for forcing as well as for outside culture. Pkt. 5c;oz. 15c

$1 / 4$ bl. $40 \mathrm{c} ; \mathrm{lb}$. $\$ 1.25$.

EARLY CURLED SIMPSON. Highly recommended for general culture, Pkt. 5c; oz. 15c; $1 / 4$ lb. 40c; lb. $\$ 1.25$.

EARLY CURLED SILESIAN. The old favorite. Golden leaves with finely curled edges.

Pkt. 5c; oz. 15c; $1 / 1$ lb. 40c; lb. $\$ 1.25$.

EARLY PRIZEHEAD. Good variety, bright green, tinged with brownish red. Pkt. 5c; oz $15 c ; 1 / 4$ lb. 40c; lb. $\$ 1.25$. 
NEW YORK LETTUCE. This variety is becoming very popular with market gardeners and shippers of lettuce. It is sometimes called Cabbage Head Lettuce, as it produces immense heads, often measuring 15 to 16 inches across. The heads are very heavy and compact. The interior is beautifully blanched and creamy white, crisp and tender, being absolutely free from any trace of bitterness. It is very large, robust growing variety, rooting well, resists hot weather much better than any other variety of Lettuce that we know of. It is very slow to run to seed, therefore keeps much better in the field than most varieties. We especially recommend this variety to shippers, as it keeps well. The outer color is a distinct apple green. Price, pkt. 5c; oz. 20c; $1 / 4 \mathrm{lb} .60 \mathrm{c} ; 1 / 2 \mathrm{lb} . \$ 1.00 ; \mathrm{lb}$. $\$ 1.75$

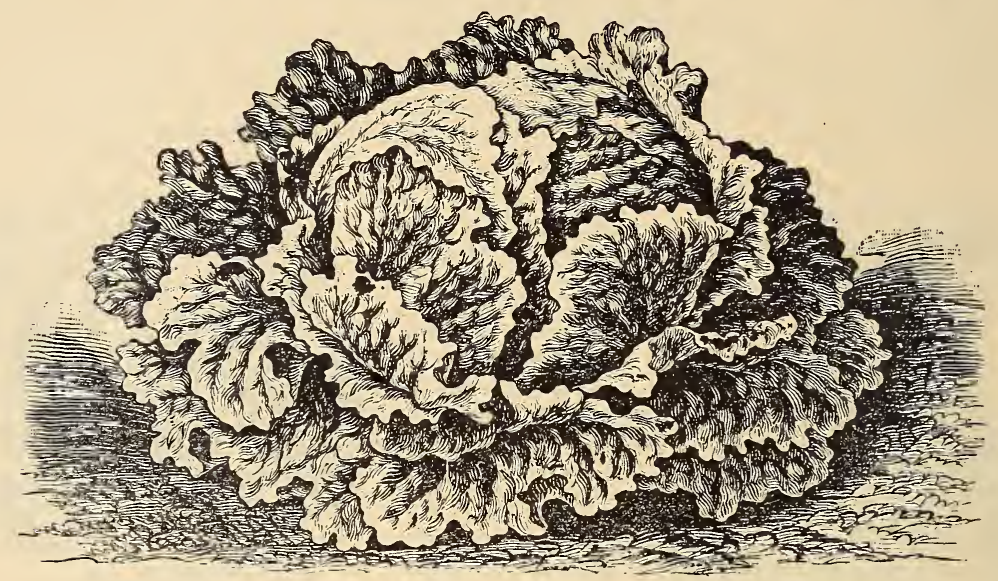

NEW YORK

HANSON. The heads are of a very large size, deliciously sweet, tender and crisp, even to the outer leaves; heads weigh $21 / 2$ to 3 pounds and measure $1 \frac{1}{2}$ feet in diameter. Color green outside and white within; free from any bitter, unpleasant taste. Not recommended for forcing, but has few superiors for family use. Pkt. 5c; oz. 15c; $1 / 4$ lb. 40c; lb. $\$ 1.25$.

EARLY CABBAGE OR DUTCH BUTTERHEAD. Produces the greenish white, large heads of extra quality; remarkably tender and crisp, sure to head, of quick growth. It is one of the best for forcing and also for summer use, as it is slow to shoot seeds and resists heat well. Pkt. 5c; oz. 15c; $1 / 4$ lb. 40c; lb. $\$ 1.25$.

This remarkable sort belongs to the "Crisp Head Lettuces" and is a decided acquisition. It forms a large, solid head, the only outside leaves being of a light green color, while the inside is being bleached and is almost white. It is quite as well adapted for planting in the summer as in the spring, as the hottest summer weather cannot cause the leaves to open outward and expose the heart. The usual solidity of heads makes it, in our opinion, the ideal summer lettuce, and we strongly recommend our customers to give this splendid variety a trial. Pkt. 5c; oz. 20c; $1 / 4$ lb. 60c; lb. $\$ 1.75$.

\section{ALL SEASONS}

All Seasons Lettuce is a distinct black seeded variety forming splendid solid heads of a light silvery green color. These heads are large and will "stand" longer before going to seed than those of any other Butterhead variety. The leaves are of a rich yellow color, crisp, tender, and of mild flavor. Pkt. 5c; oz. 15c; $1 / 4$ lb. 40c; lb. $\$ 1.25$.

\section{CRISP-AS-ICE}

A beautiful lettuce of the cabbage type. The solid heads are of medium size, and the leaves are so tender and brittle as to have suggested the name bestowed up on it. The heads, when cut open. have a rich, creamy yellow heart. The leaves are thick and glossy, somewhat curled, of a good and attractive green color, variegated with bronze. Crisp-as-Ice cannot be over-estimated or over-praided for home use in spring and summer or late in fall. Pkt. 5c; oz. 25c; 1/4 lb. 75c; lb. \$2.50.

\section{PARIS WHITE COS}

This is an excellent variety, although it is not quite as early as the round head varieties. It forms large, light green plants, well folded and quite solid The interior is well blanched, and of a crisp, fine flavor, although the flavor is somewhat stronger than that of the preceeding sort. Pkt. 5c; oz. 15c; $1 / 4 \mathrm{lb}$. 50c; lb. $\$ 1.50$

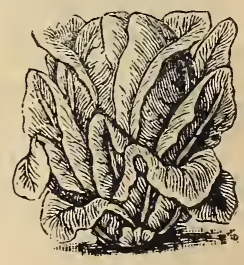




\section{CANTALOUPES OR MUSK MELONS}

\section{Zucker Melonen.}

Melon Almizelena o centaiu.

CULTURE. The soils for Musk Melons must be light, rich and sandy, for if grown on a heavy soil the quality will be poor, and they will not be so early. When there is no danger of frost drop 8 to 10 seeds in a hill 6 feet apart, each way, covering about three-fourths inch deep. As soon as a plant commences to run, thin out to 3 best plants in a hill and cultivate until the vines cover the ground. If slow to fruit, pinch off the ends of the growing shoots. Slug Shot sifted on the young plants while the dew is on is good to keep insects out. One ounce will plant about sixty hills, and it takes two pounds to one acre.

THE ROCKY FORD. This melon grown first in Rocky Ford, Colorado, has in a few years acquired a national reputation. It is of the Netted Gem type, oval in shape, averaging from $41 / 2$ to 5inches in length. It has a most delicious flavor, is very fine and smooth grained, has flesh of light green color throughout when ripe. Our seed comes from Rocky Ford where this melon is raised so extensively and from where carloads upon carloads are shipped out every season. Texas grown seed an excellent strain. Pkt. $5 \mathrm{c} ;$ oz. 10c; $1 / 4$ lb. 25c; lb. 80c. Genuine Rocky Ford Seeds grown under our personal supervision in Colorado. Pkt 5c; $1 / 4$ lb. 30c; lb. $\$ 1.00$.

HONEY DEW MELON. A new melon having a distinct, delicious flavor. The melon was produced by crossing the well-known Rock Ford with an African melon. The result of this cross was then crossed with the Improved Hybrid Cassaba and this produced a melon which retained the sweetness of the Rocky Ford, the delicious flavor of the African melon and the smooth hard shell of the Cassaba Pkt. 10c; oz. 20c; 1/4 lb. $\$ 60 ; 1$ lb. $\$ 2.00$.

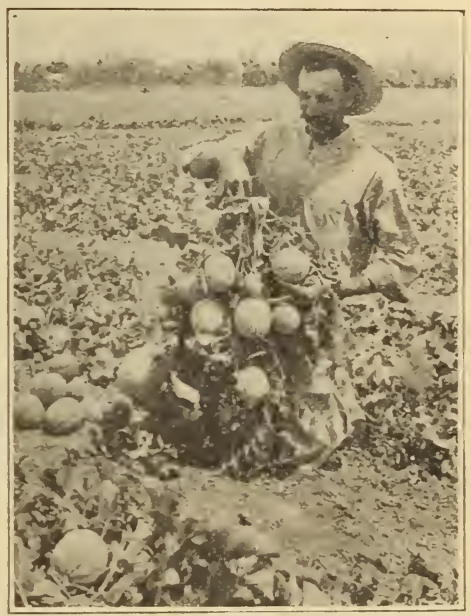

NETTED NUTMEG. We consider this the very best variety in cultivation. Vines, vigorous, hardy, productive, fruit round, slightly flattened at both ends, ribbed, covered with coarse netting; flesh very thick, green and of the highest flavor. Pkt. 5c; oz. 10c; $1 / 4$ bl. 30c; lb. $\$ 1.00$.

CASSABA, OR LARGE PERSIAN. Long oval shaped, skin very thin and delicate: flesh extremely tender, rich and sweet. Pkt .5c; oz. 10c; $1 / 4 \mathrm{lb} .20 \mathrm{c} ; 1 \mathrm{~b} . \$ 1.00$.

GOLD LINED NETTED ROCK. This solid netted, deep-meated cantaloupe is an excellent melon, and will be planted extensively. The flesh is green next to the rind, changing to golden next to the seed cavity. The meat is about one-half green and one-half golden, very firm and fine grained and so thick that the seeds are held firmly in a small, three-cornered or triangular cavity. Pkt. 5c; oz. 15c; $1 / 4 \mathrm{lb} .50 \mathrm{c}$; lb. $\$ 1.50$.

EXTRA EARLY HACKENSACK. By careful selection and improvement carried on for some years this strain has been developed so that it produces melons with all the good qualities of well known Hackensack Melon, but at least ten days earlier. Pkt. 5c; oz. 10c; $1 / 4 \mathrm{lb}$. 30c; lb. $\$ 1.00$

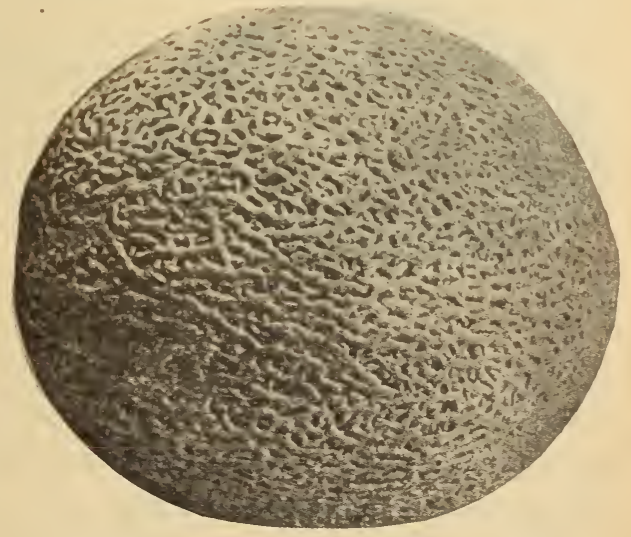

Gold Lined Netted Rock 


\section{CANTALOUPES OR MUSK MELONS-Continued YELLOW-FLESHED VARIETIES}

NEW MUSK MELON' BURRELL'S GEM. It was hard to beat the Rocky Ford, and yet is has been done. The new variety has a salmon flesh of unusual thickness and flavor that can hardly be surpassed. The flesh is $11 / 2$ to 2 inches thick, the rind is heavily netted, slightly ribbed and very thin. The melons grow to an average size of six inches in length and $4 \frac{1}{2}$ inches in diameter, weigh about 2 pounds apiece. They are ideal shipping melons, and, notwithstanding the thin rind, have stood shipment from Colorado to New York in perfection. Pkt. 5c; oz. 10c; $1 / 4 \mathrm{lb} .30 \mathrm{c}$; lb. $\$ 1.00$.

DEFENDER. A splendid variety. It is one of the very best yellow-fleshed sorts and in some respects is far superior to any of this class. The fruit is medium sized, oval in shape, slightly ribbed, covered with a gray netting. The flesh is firm, finely grained, and of a rich deep yellow color. Pkt. 5c; oz. 10c; $1 / 4 \mathrm{lb}$. $30 \mathrm{c} ; \mathrm{lb} . \$ 1.00$.

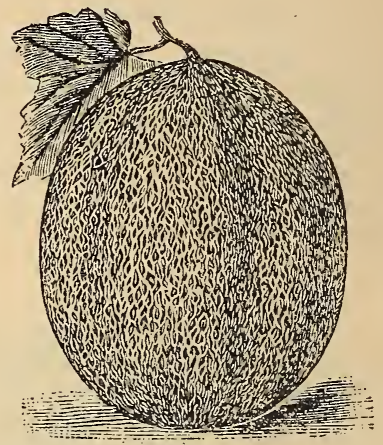

BURRELL'S GEM

EMERALD GEM. This is a variety of excellent quality; it is of medium size. The skin is, while ridged, perfectly smooth and of deep emerald green color, and ripens to the green rind. It is peculiarly crystalline in appearance, and so very juicy and rich that it almost drops to pieces when dipped out with a spoon. The flavor is very sweet and luscious. The vines are hardy and very prolific, and the melons mature extremely early. Pkt. 5c; oz. 10c; $1 / 4 \mathrm{lb}$. 30c; lb. \$1.00.

KHIVA OR WINTER MUSK MELON. Musk Melon for Christmas dinner. You can have such and from your own garden, if you plant Khiva. It is the most delicately flavored winter keeping melon we have ever eaten. The skin is firm, with a grayish color, green slightly mottled. Is of egg shape and weighs 12 to 30 pounds. Not real delicious until November and later. They keep nicely until January. Pkt. 10c; oz. 20c; $1 / 4$ lb. 70 c.

PEACH OR GARDEN MELON. The fruit is about the size of a large peach, oval-shaped and of a bright orange vellow color, somewhat russetted. When it first ripens it is quite hard and has very little flavor, but they soon become mellow, not sweet. and have a rich flavor, but for sw eet pickles pies, or preserving, they are superb. Pkt. 5c, oz. 10c; $1 / 4$ lb. $45 \mathrm{c}$; lb. $\$ 1.20$.

BANANA. An entirely distinct variety, bearing long slender banana-like fruit. Flesh deep salmon solor, thick and of good quality. Pkt. 5c; oz 15c; $1 / 4 \mathrm{lb} .40 \mathrm{c} ; \mathrm{lb} . \$ 140$.

MUSK MELON WINTER CASSABA. IVinter Melons are becoming more pop slar every yeı and these two varieties have given best results.

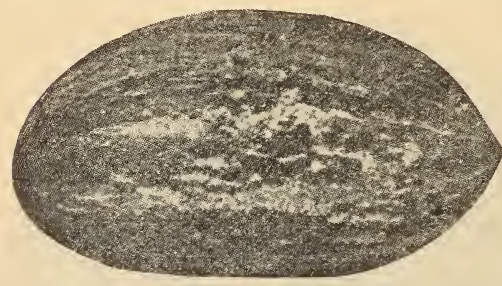

SANTA CLAUS

SANTA CLAUS. The name is well appropriated, as you cannot have anything more delicious for your Christmas dinner. The rind has the appearance of a mottled pomegranite. The shell is hard and about one-eighth inch thick. There is no seed cavity. The seeds are embedded in a jelly-like pulp. The light green flesh is absolutely stringless. Plant the seed early: pick when the green turns to bright yellow and put away until slightly soft. Pkt. 10c; oz. 25c; $1 / 4$ lb. 75c; lb. $\$ 2.50$.

WINTER PINEAPPLE。 This is the green melon used extensively for shipping East for the holiday and winter trade. Melons do not mature on the vines and the flavor is greatly improved by being stored in a cool place. Pkt. 10c; oz. 20c; 1/4 lb. 60c; lb. \$2.00.

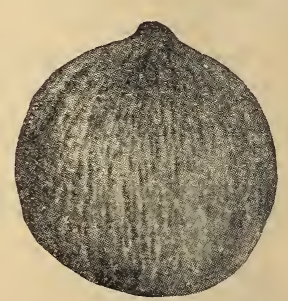

Winter Pineapple 
Wassermelonen.

\section{WATER MELONS}

Our water melon grower who raises them on a large scale places us in a position to offer the very best seed at reduced prices.

Melon seed has been one of our specialities for years and we supply many of the leading seed houses of the country.

If you are in the market for a large quantity of melon seeds, be sure and ask us for special prices.

CULTURE. The same as for Musk Melon except that they should be planted from $S$ to 10 feet apart. One ounce for 30 hills; $1 \frac{1}{2}$ to 2 pounds to the acre.

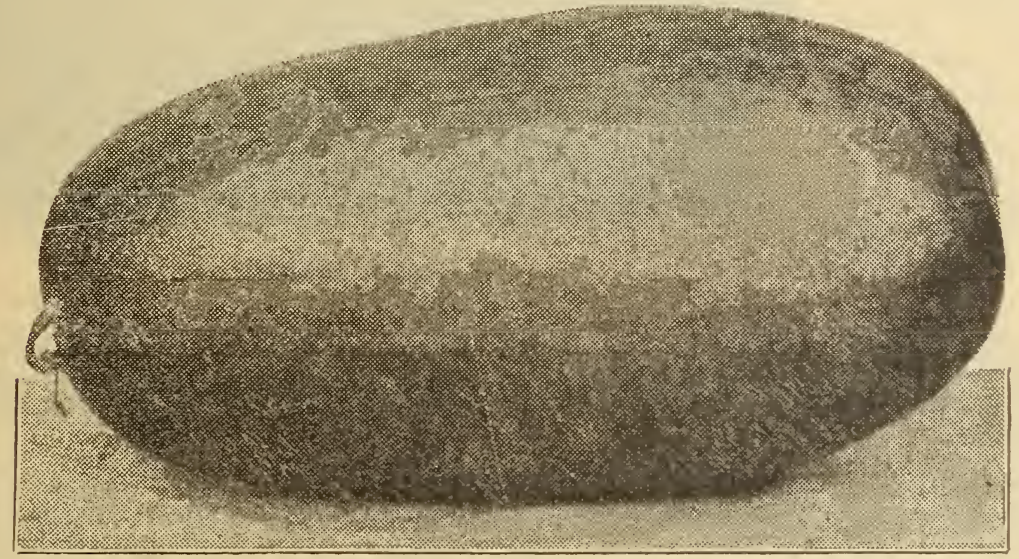

TOM WATSON

TOM WATSON. In the last few years this melon has become immensely popular. The average fruit of this variety reaches the size of 24 to $2 *$ inches long and 12 to 14 inches in diameter. It has a dark mottled green rind, thin, but tough enough to stand shipping long distances. For the home or for the market garden or for shipping it is a money-maker for the growers. The seed we offer is of the very best strain. Pkt. 5c; oz. 10c; $1 / 4$ lb. 25c; $1 / 2$ lb 40c. lb. 75c.

HALBERT HONEY. Originally grown in Texas, it comes to us from the East, where, owing to its superb qualities, it has won a reputation in an incredibly short time. The melons are oblong of form, symmetrically rounded at both ends, The skin is smooth. of dark green color, thin and rather brittle; on this acc ount the melons do not stand shipping well. They are, however, the best melons for home use ana nearby markets. The flesh is of a beautiful crimson color, of luscious flavor and entirely free from strings. Try Halbert Honey this year. Pkt. $5 \mathrm{c} ;$ oz. 10c; $1 / 4$ 1b. 25c; 1b. 90c.

KLECKLE Y SWEETS. This melon is dark green, the flesh is scarlet, ripening close to the skin. the rind being only about one-half inch in thickness. Seeds white, lying close to the rind, leaving a large, solid heart, which does not crack open when ripe, The scarlet flesh is sweet and sugary, and of such texture that it leaves no string of pulp whatever in eating. Pkt. 5c; oz. 10c; 1/4 lb. 25c; lb. 90c.

FLORIDA FAVORITE. Oblong in shape, growing to a very large size, rind dark with light green stripes, flesh light crimson, crisp and deliciously sweet. Pkt. 5c; oz. 10c; 1/4 lb. 25c; 1b. 90c.

GYPSY OR GEORGIA RATTLESNAKE. The melon is long, smooth, distinctly striped with light, mottled and wavy dark green stripes. Flesh bright scarlet, and very sugary. Notwithstanding its thin rind it will stand shipping well. Pkt. $5 \mathrm{c} ;$ oz. 10c; $1 / 4 \mathrm{lb} .25 \mathrm{c} ; 1 \mathrm{~b} .90 \mathrm{c}$.

SWEET HEART. An excellent melon, Vine vigorous, productive and ripens its fruit early. Fruit is large, oval, very heavy, uniformly mottled light and dark green. Rind thin but very firm. Flesh bright red, solid, very tender, melting and sweet. Pkt. 5c; oz. 10c; $1 / 41 \mathrm{~b} .25 \mathrm{c} ; 1 \mathrm{~b} .80 \mathrm{c}$.

KENTUCKY WONDER. In shape it is oblong, skin dark green, marbled in stripes of light green. The flesh is of a beautiful scarlet color, crisp and of rich sugary flavor. It is always firm and never mealy. Attains an average weight of 30 to 40 pounds. Pkt. 5c; oz. 10c; $1 / 4 \mathrm{lb} .25 \mathrm{c} ; \mathrm{lb} .80 \mathrm{c}$. 


\section{WATERMELON-Continued.}

\section{ALABAMA SWEET.}

A long melon with dark skin and red flesh. One of the first to come into market, is good grower and will bear longer than any other variety. It has light seeds, is of good size though not ungainly, and is a first class shipper. Raised extensively in Texas, where it brings extra prices. Pkt. 5c; oz. 10c; $1 / 4$ lb. 25c; 1b. 75c.

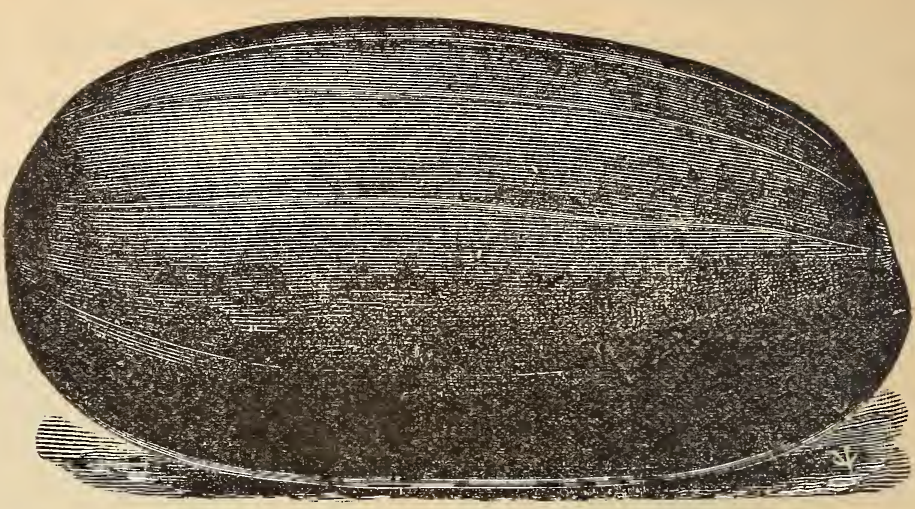

ALABAMA SWEET

GOLDEN HONEY. A beautiful, golden-flesh melon, one of the finest we have ever tasted. The flesh is a beautiful, glistening amber shade of yellow, very tender, and has a most de licious flavor, very similar to that of the celebrated Halbert Honey Watermelon. Pkt. 10c; oz. 20c; 1/4 lb. 60c; $1 / 2 \mathrm{lb}$. $\$ 1.10 ; 1 b . \$ 200$.

“KING AND QUEEN" WINTER WATERMELON. Average weight 25 pounds. Spherical in shape, ivory shell, pink center, seeds black. The most luscious, handsome and valuable winter melon in the world. It is very hardy, a good drouth resister, and does well in any soil which grows melons; never sets an imperfect specimen on its vines, and ripens every melon in less than 120 days. It is a prize-taker every where. These melons have been shipped to market as late as December. Ripens on the vines the third week in August and does not change its condition for ninety days if not bruised. The shell is very hard and the melon ripens to within one-eighth of an inch of it. Pkt. 10c; oz. $20 \mathrm{c} ; 1 / 4 \mathrm{lb}$. 60c; lb. $\$ 2.00$.

THE ROCKY FORD. The famous Water Melon is in a fair way to become as popular as the Canteloupe of the same name. Fruit is of large size, oblong in shape, averaging eighteen to twenty inches in length to ten to twelve inches in diameter. The appearance is handome, the flesh is a bright scarlet with a flavor which is superbly delicious. Unfortunately the skin is too tender to admit of shipping to any great distance, but its other excellent qualities make it the most desirable for home use and for selling in nearby markets. Pkt. $5 \mathrm{c} ;$ oz. $10 \mathrm{c} ; 1 / 4 \mathrm{lb} .25 \mathrm{c} ; \mathrm{lb} .80 \mathrm{c}$.

PRIDE OF GEORGIA. A much better table variety than the Kolb Gem, though not so good a shipper, owing to the exceeding thinness and ienderness of the rind. Pkt. 5c; oz. 10c; $1 / 4$ lb. 25c; lb. 80c.

ANGELENO. The deep red flesh and excellent flavor of this melon commends it to the consumer, while the beautiful dark green color of the rind makes it attractive to the buyer. Do not pick until the yellow shows slightly through the green, as it is a sure sign that the melon is ripe. Pkt. 5c; oz. 15c; $1 / 4$ lb. 50c; lb. \$1.50.

KANSAS STOCK OR COLORADO PRESERVING MELON. A boon to the dry land farmer. This melon is grown extensively in Oklahoma, Kansas, and Texas. It is immensely productive. The melons grow to a large size, some of them weighing as high as 60 to 70 pounds. The flesh is firm and solid with only very few seeds. The melons will keep all winter and can be fed to stock the same as turnips and beets. They grow on most any kind of soil, stand dry seasons very well and seem adapted to most climates. Pkt. 5c; oz. 10c; $1 / 4$ lb. 25c; lb. 80c.

CITRON. For preserving. Rind striped and marbled with light green, flesh white and solid. Pkt. 5c; oz. 10c; $1 / 4$ lb. 25c; lb. 80c. 


\section{Champigonbrut.}

Mushrooms can be grown wherever there is a cellar or a close shed, in which an even temperature of from fifty to sixty degrees can be maintained and where a plentiful supply of fresh horse manure for making the beds can be obtained. You can have these delicious fungi, considered one of the finest delicaices, by getting good spawn from us and by following the directions given in our book, "How to Grow Mushrooms," price 10c' postpaid.

\section{PURE CULTURE SPAWN.}

1 brick

2 bricks

4 bricks.

With every order for four bricks, at mail prices, we shall be pleased to send the above-mentioned book, "How to Grow Mushrooms," free of charge.

By Express at purchaser's expense:

5 bricks.

10 bricks

25 bricks

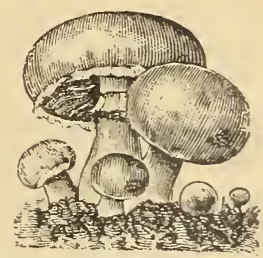

Mushroom

\section{MUSTARD \\ Moutrarde (Fr.), \\ Senf (Ger.).}

CULTURE. This is grown to quite an extent in the Southern States, and is sown broadcast during Fall, Winter and Spring. It may be used the same as Spinach, or boiled with meat as greens. The White or Yellow Seeded is very little cultivated and is used chiefly for medicinal purposes, or pickling. The large-leaved or curled has black seed, a distinct kind from the Northern or European variety.

GIANT CURLED SOUTHERN. Highly esteemed for salads, particularly in the South. The leaves are twice the size of the ordinary White Mustard; flavor sweet and pungent. Pkt. 5c; oz. 10c; $1 / 4$ lb. 30c; lb. $\$ 1.00$.

OSTRICH PLUME. The leaves are long, ruffled, and curled as gracefully as an ostrich plume. Is especially good as a salad and as greens, equal to spinach. The growth of leaves makes it a very ornamental plant. Pkt. 5c; oz. $10 \mathrm{c} ; 1 / 4$ lb. 30c; 1b. $\$ 1.00$.

CHINESE. A very hardy variety. Leaves are large, thick and deeply savoyed with broad white mid-rib. Pkt. 5c; oz. 10c; 1/4 lb. 30c; lb. $\$ 1.00$.

ELEPHANT EAR MUSTARD. Leaves attain a length of from eighteen inches to 2 feet, they' are of light green color with large white ribs or leaf stock, highly recommended. Oz. 10c; 1/1 lb. 30c: Ib. $\$ 1.00$.

WHITE ENGLISH. Leaves are light green, mild and tender when young; seed light yellow. Pkt. 5c; oz. 10c; $1 / 4$ lb. 25c; 1b. 80c.

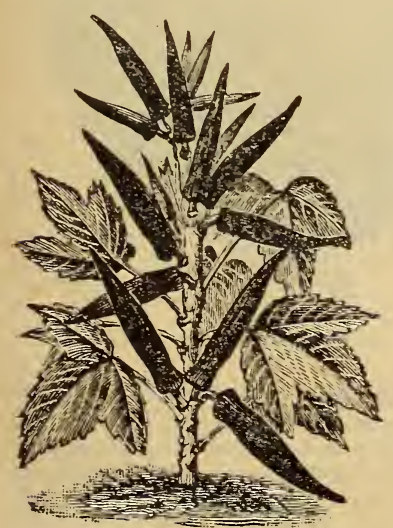

\section{OKRA OR GUMBO}

\section{Safran. Quimbombo.}

One ounce will plant 100 hills.

CULTURE. Sow late in the spring, after the ground has become warm, in drills 3 feet apart, and when the plants are three inches high thin out from 10 to 12 inches. They should be well manured. They also can be started in a hot bed and transplanted afterwards. The young green seed pods of this plant are used in soups or stewed and served like asparagus. The young pods can also be dried for winter use.

EARLY DWARF PROLIFIC. Short podded and productive. Pkt, 5c; oz. 10c; $1 / 4$ lb. 20c; lb. 50c.

TALL. Grows to a height of five feet Pods usually eight ridged and about 6 inches long. Pkt. $5 \mathrm{c} ; \mathrm{oz} .10 \mathrm{c} ; 1 / 4 \mathrm{lb} .20 \mathrm{c} ; 1 \mathrm{~b} .50 \mathrm{c}$.

\section{Okra Dwarf}

WHITE VELVET. It is very distinct in appearance, and unlike other varieties the pod is not ridged but is perfectly smooth and round. They are of attractive appearance and superior flavor and tenderness. The plants are comparatively dwarf and of compact, branching growth; the pods are of extra large size and produce in great abundance. Pkt. 5c; oz. $10 \mathrm{c} ; 1 / 4 \mathrm{lb} .20 \mathrm{c} ; 1 \mathrm{~b} .60 \mathrm{c}$. 


\section{ONIONS}

Zwiebeln.

Cebollaos.

We make a specialty of onion seed and handle it extensively. We import a large portion of our seed which have been grown under careful supervision. Our seed is grown from choice selected bulbs and can be relied upon. We make special prices to gardeners and others using seed in large quantities.

CULTURE. The onion thrives best in rather deep, rich loamy soil, unlike most vegetables, succeeds well when cultivated on the same ground for successive years. As early in the spring as the ground is in working order, commence operations by leveling the ground with a rake; sow thickly in rows a quarter of an inch deep and one foot apart; cover with fine soil and press down with the back of the spade or a light roller. When the young plants are strong enough, thin gradually so that they stand 3 to 4 inches apart. Keep the surface of the ground open and free from weeds by frequent hoeing, taking care not to stir the soil too deeply, or collect it about the growing bulbs. When ripe, pull and dry thoroughly before storing. As maggots are the worst enemies of an onion patch, commercial fetrilizers are better to use than manures, which originate maggots. One ounce to 100 feet of drill 3 pounds to an acre.

\section{AMERICAN YELLOW VARIETIES}

AUSTRALIAN BROWN. This fine onion is extra large and sure to make a good crop. This onion is of special merit because of its excellent keepıng qualities, bulbs remain in excellent condition antil almost a year after they are harvested. The advantage of this is easily seen, especially by the Southern growers. In shape and form they resemble somewhat the round Yellow Danvers, but the former are heavier in every case. The skin is quite thin and bright reddish brown, while the flesh is solid, crisp and mild. Pkt. 5c; oz. 20c;1/4 lb. 65c; lb. \$2.40.

YELLOW GLOBE DANVERS. A very excellent variety of globular shape; flesh white and of a mild flavor, skin brownish yellow. It is very productive and a good keeper. Pkt. 5c; oz. 20c; $1 / 4$ lb. 65c; lb. \$2.40.

FLAT YELLOW DANVERS. Same as Globe Danvers, except in shape. Pkt. 5c; oz. 20c; $1 / 4$ lb. 65c; lb. $\$ 2.40$.

PRIZETAKER. This handsome variety is a splendid type of the celebrated Spanish fancy onions, which are annually imported into the United States from Spain and sold by confectioners and fruiters in our large cities at from 25 to 50 cents each, and even higher. The onions grown here quite rival the imported one in great beauty and enormous size. The outside skin is of a greenish yellow color, while the flesh is white, sweet and mild. Pkt. 5c; oz. 25 c; $1 / 4$ lb. $80 \mathrm{c}$; lb. $\$ 3.00$.

GIGANTIC GIBRALTER ONION. This comparatıvely new and little known variety is particularly adapted for growing in warm climates. In appearance it is very similar to the well known "Prize Taker" Onion; will grow

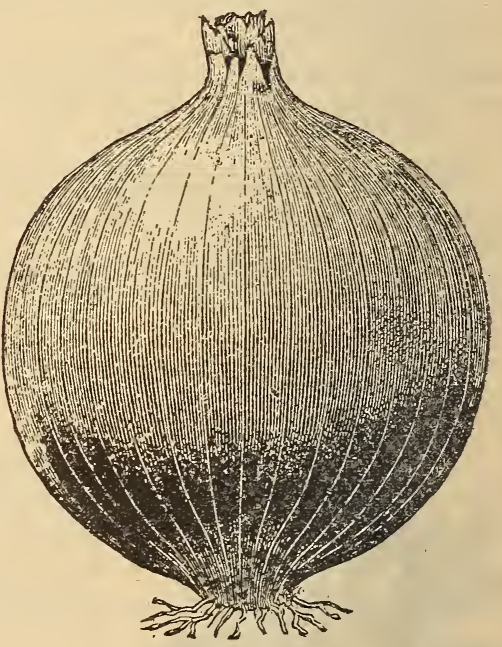

Prizetaker larger under favorable conditons. The handsome globular shaped bulbs have a light straw colored skin, while the flesh is white and very mild. The ripe onions are excellent keepers and surpass, in this respect, most of the other varieties if properly handled. Experiments have shown that of onions harvested in August, fully 95 per cent were in fine marketable condition in January, free from split and rotting. Pkt. 5c; oz. 30c; $1 / 4$ lb. $\$ 1.00$.

ONION SEED is one of our best leading specialties; you will make no mistake in sending us all of your ONION SEED orders this year. 


\section{ONIONS-Continued AMERICAN WHITE VARIETIES}

SOUTHPORT WHITE GLOBE. Yield abundantly, producing handsome and uniformly globe-shaped bulbs. The flesh is firm, fine grained and of fine flavor. Pkt. 5c; oz. 25c; 1/4 lb. 80c; ib. $\$ 3.00$.

LOUISIANA OR WHITE CREOLE. Is similar in shape and hardiness to Red Creole Onion, but silvery white in color, the veins clear and distinct. Its mild, pleasant $f$ lavor and splendid keeping qualities make it a favorite White Onion for shipping. Pkt. 10c; oz. 75c.

WHITE SILVERSKIN OR PORTUGAL. A mild, pleasant flavored variety, admirable for family use; not so good a keeper as the dark-skinned varieites. Pkt. $10 \mathrm{c} ;$ oz. $30 \mathrm{c} ; 1 / 4 \$ 1.00 ; 1 \mathrm{~b} . \$ 3.50$

\section{AMERICAN RED VARIETIES}

SOUTHPORT RED GLOBE. A large globe-shaped onion, with small neck and rich red color; a splendid keeper and of extra fine quality. It matures a few days later than the Red Wethersfield. Pkt. 5c; oz. 25c; $1 / 4$ lb. 80c; lb. $\$ 3.00$.

LARGE RED WETHERSFIELD. The old standard sort; best for main crop. Large, dep red, thick, nearly round, fine grained, of pleasant flavor a good yielder, andkeeps well. Pkt. 5c; oz. 25c; $1 / 4$ lb. 80 c; lb. $\$ 3.00$.

RED CREOLE. In this latitude the seed should be sown from the 15th of September to about the 25th of October; if sown sooner, a good many will throw up seed stalks, which !mpairs the keeping quality of the Onion. Can be planted in the same ground for years, and require no rotation as other crops. When the plants have reached the size of a goose quill they are transplanted into rows which can be from one to two feet apart, accordingly to the mode of cultivation, and about fiv or six inches apart in the rows. The ground should be prepaired before setting out the plants. We generally shorten the tops and roots. In April the Onion will be ready to be taken in. In sections where it is too cold to sow onion seed in the fall, the Creole seed can be sown in January and February; in that case they should be sown very thinly in drills, thinned out to a proper stand, and This picture below shows a partial view of the tufts on balls "being dried under the sun by our grower at Teneriffe. by the end of spring they will pro. duce good size onions. Pkt. 5c; oz. $75 \mathrm{c}$.

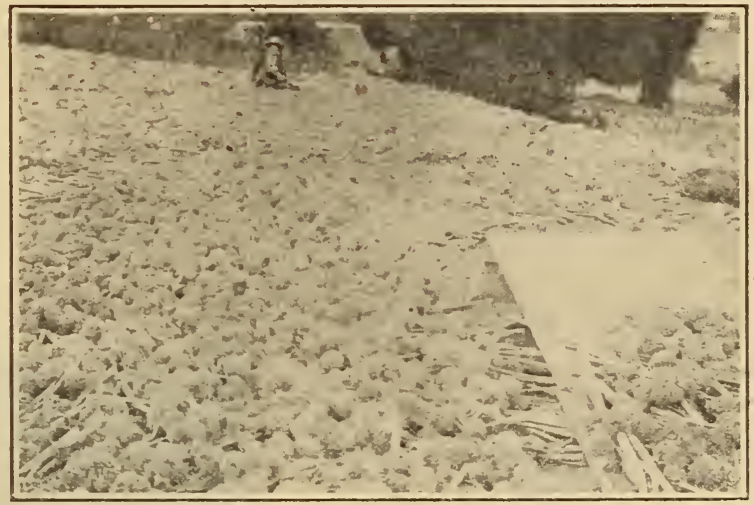

ITALIAN VARIEITES (Crop failed)

GIANT ITALIAN TRIPOLI. A large, beautiful, pure white onion of mild excellent flavor. Will produce a somewhat larger onion from seed than our White Portugal, but to attain their full size the plant should be started very early in a hot bed and set out in rich soil. Pkt. 5c; oz. 20c; $1 / 4 \mathrm{lb}$. 65c; lb. $\$ 2.40$.

EARLY WHITE QUEEN. Succeeds well everywhere. The bulbs are small, flat, beautif ully white and of excellent flavor, but the principal recommendation is the marvelous rapidity of their growth.

It will produce ripe oinons in 100 to 110 days from date of sowing. Both the White Queen and the Extra Early Barletta are highly recommended for pickling purposes. Pkt. 5c; oz. 20c; 1/4 lb. 60c; lb. $\$ 2.00$.

MAMMOTH SILVER KING. We have imported seed of this truly mammoth variety. The onions are of attractive shape with silvery white skin and flesh of a most agreeable flavor. It reaches a larger size than any of the flat white varieties. Pkt. $5 \mathrm{c} ;$ oz. $20 \mathrm{c} ; 1 / 4 \mathrm{lb} .65 \mathrm{c} ; 1 \mathrm{~b} . \$ 2.50$.

EL PASO. A variety from Mexico. It grows there to a diameter of 6 inches, weighing twothirds of a pound, flavored very mildly. Our seed of this variety comes direct from Mexico. Skin of the onion generally white, but sometimes mixed with red and yellow. Pkt. 5c; oz. 20c; 1/4 lb. 65c; lb. $\$ 2.40$.

EXTRA EARLY BARLETTA. It is fully two or three weeks earlier than the Early White Queen, which heretofore has been the earliest variety under cultivation. The onions are of a pure paper-white color, very mild and delicate in flavor, from one inch to one and one-half inches in diameter and three-fourths of an inch in thickness. Pkt. 5c; oz. 20c; 1/4 lb. 65c; lb. \$2.40. 


\section{BERMUDA ONION SEED IMPORTED FROM TENERIFFE}

In growing onions the quality of the seed is of greatest importance Our seed is grown by the best grower in Teneriffe and is the best to be had.

YELLOW BERMUDA. This valuable onion is especially adapted to the Southern states and is the most profitable of all varieties of onions for the grower. Ease of culf tivation, large size and mildness oflavor make it the most valuable of this type. The Yellow Bermuda is a selection from the original Red Bermuda and preferred to all others by growers in the South. We offer seeds obtained direct from the Isle of Tenriffe, one of the Canary Isles, the home of the Bermuda Onion. Pkt. 5c; oz. 25c; $1 / 4$ lb. 75c; lb. $\$ 2.50$.

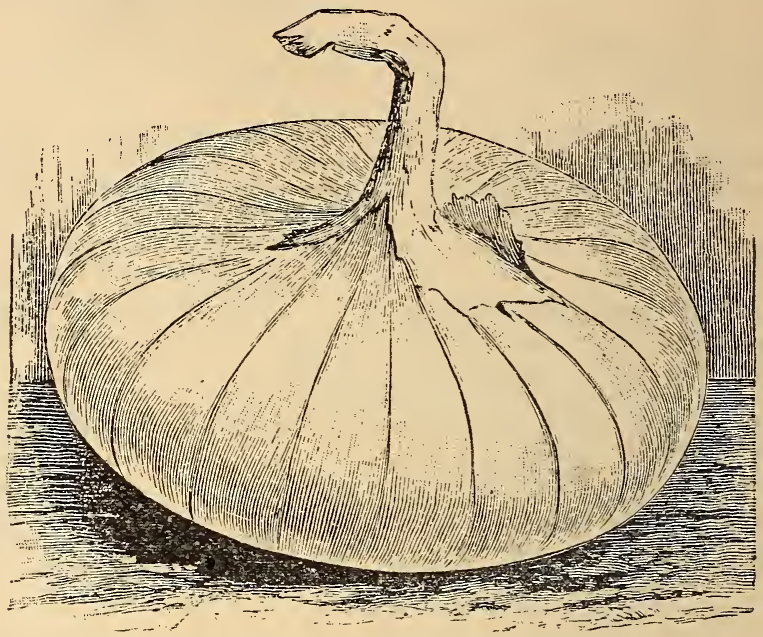

Bermuda Onion

YELLOW BERMUDA SELECT. Special selected quality seed from hand picked onions fu of life, from improved stock by continuous selection of Pedigree onions. Pkt. 10c; oz. 30c; $1 / 4 \mathrm{lb} . \$ 1.00$ lb. $\$ 3.50$.

This picture below showing the new style of support used by our grower at Teneriffe, which keeps all the plants perfectly erect in spite of strong winds.

\section{CRYSTAL W H I T E W A X .}

Teneriffe grown. This is a large, pure white, flat onion. In the South especially Texas, during the last few years, it has become so popular that there has not been enough seed to meet the demand. It grows to a good size early and is the mildest and sweetest of all onions. It is the finest slicing onion for the home garden. True seed very scarce. Pkt. 5c; oz. 25c; $1 / 4$ lb. 80c; lb. $\$ 3.00$.

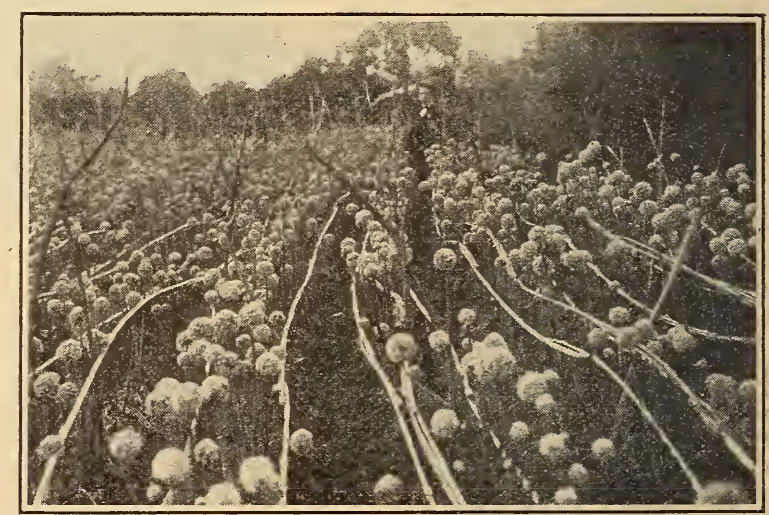

CRYSTAL WHITE WAX SELECT. Special selected quality from hand picked oni ${ }^{\circ}$ ns full o life from improved stock by continuous selection of Pedigree onions. Pkt. 10c; oz. 30c; $1 / 4^{l} \mathrm{~b} . \$ 1.00$ lb. $\$ 3.75$.

\section{ONION SETS}

Thirty-two pounds constitute a bushel, except the red top or Button Sets, and shallots which are 28 pounds per bushel.

YELLOW BERMUDA. Have sets of these. Varieties in fall only. Lb. 25c.

CRYSTAL WHITE WAX. Have sets of these. Varieties in fall only. Lb. 25c.

WHITE PEARL. Lb. 25c.

WHITE SILVERSKIN. Lb.25c.

DARK RED. Lb. 20c.

YELLOW. Lb. 20c. 


\section{ONION SETS-Continued}

WHITE MULTIPLIER. These are of a pure silvery white color, enormously productive, frequently producing as many as 20 bulbs in a cluster from a single bulb plant. It is of excellent qual. ity and size for bunching green, or can be ripened for use as pickling onions. Lb. 25c.

RED MULTIPLIER. Same as the white except in color. Lb. 25c.

RED TOP OR BUTTON. Produce no seed but instead of a small number of bulbs or onions, about the size of acorns on top of the stock. These little bulbs are used instead of seed, and will produce a large onion, maturing much earlier than from the seed. Lb. 25c.

\section{Petersilie.}

PARSLEY

Perejil.

CULTURE. Parsley succeeds best in rich, mellow soil. As the seeds germinate very slowly, 3 or 4 weeks elapse sometimes before it makes its appearance. It should be sown early in the spring, previously soaking the seeds for a few hours in tepid water. Sow thickly in rows a foot apart and half an inch deep. One ounce to 150 feet of drill.

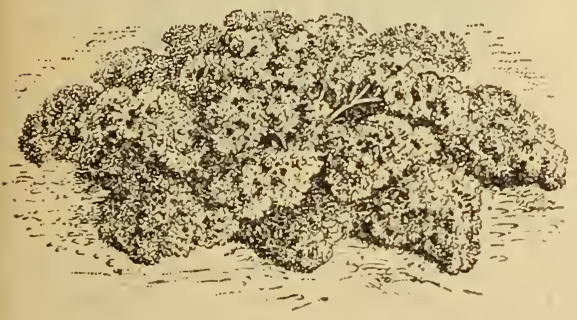

एA CHAMPION MOSS CURLED. The green leaves are finely cut and curled, and of dark green color. Extra fine for garnishing and culinary purposes. Pkt. 5c; oz. 15c; $1 / 4$ lb. 40c; lb. \$1.25.

PLAIN LEAVED. This is the hardiest variety, foliage very dark green, with plain leaves, having a strong parsley flavor and much preferred in French cooking. Pkt. 5c; oz. 15c; $1 / 4$ lb. 40c; lb. $\$ 1.25$.

DWARF PERFECTION. This new parsley well deserves the name of perfection. It combines a highly decorative appearance with a fine delicate flavor and is very desirable for planting as a border around flower beds.

The plant, if properly transplanted and given space for development, will form a symmetrical half-globe shaped bush from 6 to 8 inches high and about 10 inches across. The color is a delightful green and the leaves are attractively curled. Pkt. 5c; oz. 15c; $1 / 4 \mathrm{lb} .40 \mathrm{c} ; \mathrm{lb} . \$ 1.25$.

HAMBURG TURNIP ROOTED OR GERMAN PARSLEY. The root resembles a small parsnip and is the edible part of this sort; extensively used for flavoring soups. Pkt. 5c; oz. 15c; $1 / 4 \mathrm{lb} .40 \mathrm{c}$; lb. $\$ 1.25$.

NEW EMERALD. The plants are dwarf and of compact growth. The leaves are of a handsome bright green color, and very finely crimped and curled. It is very ornamental and commands high prices in Western markets. Pkt. 5c; oz. 15c; $1 / 4 \mathrm{lb} .40 \mathrm{c} ; \mathrm{lb} . \$ 1.25$.

\section{Pastinake.}

\section{PARSNIPS}

\section{Chirivia.}

CULTURE. They do best in deep, rich sandy soil. but will make good roots on any soil which is deep and mellow and moderatley rich. As the seed is slow to germinate, it should be sown as early as possible; cover $1 / 2$ inch deep, and press the soil firmly over the seed; give frequent cultivation, and thin the plants 6 to 8 to the foot. As they are improved by frost, a part of the crop should be left in the ground for Spring use. One ounce will sow 150 feet of drill, 5 pounds to the acre.

IMPROVED GUERNSEY. Roots comparatively short, ending somewhat abruptly with a small tap root; grows with a cavity on the top or crown of the root. Pkt. 5c; oz. 15c; $1 / 41 \mathrm{~b} .50 \mathrm{c} ; 1 \mathrm{~b} . \$ 1.50$

SUGAR OR HOLLOW CROWNED. The best for table use; a vegetable of merit, easily raised, and of great productiveness. Pkt. 5c; oz. 15c; $1 / 4 \mathrm{lb} .50 \mathrm{c} ; \mathrm{lb} . \$ 1.50$.

\section{Arvejas.}

Erbsen.

When ordering Peas to be forwarded by mail be sure to add postage.

CULTURE. Peas can be grown in every garden, but for the earliest varieties a light, warm, moderately rich soil is most suitable. The smooth kinds can be sown as soon as the ground can be worked, but the wrinkled varieties should not be planted till it is warmer, or they will rot. Sow in single or double rows from $1 \frac{1}{2}$ to 2 feet apart, dropping a pea every inch and covering from 2 to 3 inches deep. For a succession sow every ten days up to July. Sow one quart to 50 feet drilled; $11 / 2$ to 2 bushels to the acre.

PEDIGREE EXTRA EARLY. Equally as early as the choicest strain of Alaska and the peas are of much better flavor. The vines are strong bearers, producing an abundance of fine pods, generally $2 \frac{1}{2}$ to 3 inches long, well filled with from six to seven fine sweet peas. The peas ripen very uniformly and the whole crop can generally be gathered in one picking, a fact which should particularly appeal to Market Gardeners. Pkt. 5 and 10c; lb. 35c; 2 lbs. 65c; 


\section{EARLY SMOOTH VARIETIES}

ALASKA. A variety of remarkable earliness. It is a good yielder and produces pods of good size and dark green color, which are well filled with round, smooth peas of splendid flavor. The color of the dried peas is green. It ripens evenly; one picking will nearly clean off the crop. Advise market gardeners to give this variety a trial. Pkt. 5 and 10c; lb. 30c; 2 lbs. 55c; 10 lbs. \$2.50.

FIRST AND BEST. This is a reliable early cropper of the hardy smooth seed variety. Not quite as early as Alaska, Pkt. 5 and 10c; lb. 30c; 2 lbs. 55c; 10 lbs. $\$ 2.50$.

TOM THUMB. Fine, bushy, growing to a height of 10 inches; foliage heavy; productive; matures in 36 days after sprouting. Pkt. 5 and 10c; lb. 30c; 2 lbs. 55c; 10 lbs. \$2.50.

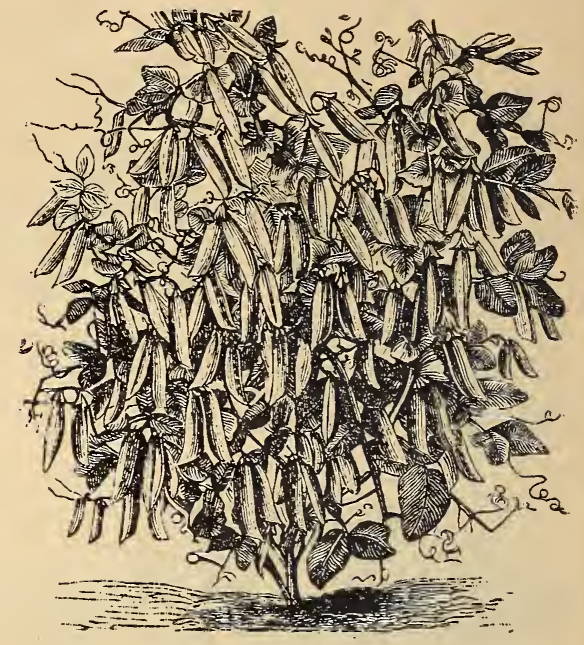

ALASKA

\section{EARLY WRINKLED VARIETIES}

GRADUS OR PROSPERITY. This remarkable pea is not only large and of the best quality, but it is also nearly as early as the small, round, extra early sorts. It is hardy and may be planted as soon as the ground is fit to work in the spring, along with smooth peas.

The vine grows to a height of about 30 inches. The pods are of a light green color and measure 4 inches or more in length, being as large as Telephone and equally as well filled with luscious peas8 to 10 in a pod The peas are of first class table quality and retain their color and attractive appearance after cooking. It is a grand pea in all respects. Pkt. 5 and 10c; lb. 30c; 2 lbs. 55c; 10 lbs. \$2.50.

AMERICAN WONDER. The vine grows 8 to 10 inches high and is very prolific in pods of striking form and size. In maturing it is among the earliest, ripening in about 50 days from germination. It is among the first of the early green wrinkled sorts. Pkt. 5 and $10 \mathrm{c} ; 1 \mathrm{~b} .30 \mathrm{c} ; 2 \mathrm{lbs}$. 55c; 10 lbs. $\$ 2.50$.

NOTT'S EXCELSIOR. Robust and vigorous in growth, very prolific, producing a prof usion of long handsome pods, closely packed with large peas of fine flavor. An improvement on American Wonder, being more vigorous and prolific with large pods with more green peas than either the Wonder or Premium Gem. Seeds green, wrinkled, square at the ends like the American Wonder. Height 12 inches. Pkt. 5 and 10c; lb. 30c; 2 lbs. 55c; 10 lbs. \$2.50.

\section{MAIN CROP VARIETIES}

DWARF CHAMPION. This is a dwarf-growing strain of the popular Champion of England, which for many years has been considerd the Standard Pea for main crop and summer use. The stocky vines grow only two feet high and set large well-filled pods very freely. In warm soils and locations this dwarf type will give better results than the tall strain. Pkt. 5 and 10c; lb. 30c; $2 \mathrm{lbs}$. 55c; 10 lbs. \$2.50.

BLISS EVERBEARING. The vines attain a height of $2 i / 2$ to 3 feet; foliage large; the pods will a verage 3 to 4 inches in length, each pod producing 6 to 8 wrinkle peas. These peas are very large. being half an inch and over in diameter, and in quality unsurpassed. For a continuance of bearing this variety is unexcelled. Pkt. 5 and 10c; lb. 30c; 2 lbs. 55c; $10 \mathrm{lbs}$. \$2.50.

TELEPHONE: This variety is one of the finest branching, tall, wrinkled marrows yet introduced. It bears splendid peas of the finest quality and excellent sugary flavor; vine very strong, averaging 18 to 20 pods per plant, the pods are of a large size and closely vacked with from 8 to 10 large, delicious peas. Pkt. 5 and 10c; lb. 30c; 2 lbs. 55c; 10 lbs. \$2.50.

PRIDE OF THE MARKET. This famous New England Pea has given great satisfaction. It grows from 18 inches to 2 feet high and has grand pods, well filled with large peas of excellent flavor. Its robust growth, enormous productiveness and superior appearance make it a favolite Pkt. 5 and 10c; lb. 30c; 2 lbs. 55c; 10 lbs. \$2.50. 


\section{PEAS-Continued}

\section{MARROWFATS AND SUGAR PEAS}

BLACKEYE MARROWFAT. A very productive variety of strong growth; requiring much space. If grown in the garden, brushwood or poles are necessary. Matures in 80 days after germination. Pkt. 5 and 10 c; lb. $30 \mathrm{c} ; 2$ lbs. 55c; 10 lbs. $\$ 2.50$.

WHITE MARROWFAT. Very similar to the Blackeye Marrowfat, except that it does not have black eyes. Pkt. 5 and 10c; lb. 30c; 2 lbs. 55c; 10 lbs. $\$ 2.50$.

GRAY SUGAR. (Edible pods.) A splendid variety with edible pods. It grows medium high, and is remarkable for its prolific character. The pods are flat and crooked and contain 5 to 6 peas. Pkt. 5 and $10 \mathrm{c} ; \mathrm{lb} .30 \mathrm{c} ; 2$ lbs. 55c.

Note. If you are in need of peas in large quantities write us. We will make prices that will please you.

\section{PEPPER}

Pfeffer.

Pimiento.

CULTURE. Pepper should be started in a hot bed in January, and not planted outside until the ground is warm, and there is no more danger of frost. Set the plants in rows 2 feet apart and 18 inches in the row. Hoe often and keep the weeds down. One ounce produces about 1,000 plants.

CHINESE GIANT. One of the very best and largest mango Peppers ever introduced. Its mammoth size, splendid shape, beautifully rich, glossy-red flesh and mild flavor, all lead us to recommend it very highly. Its strong bushy plants are heavily loaded with large fruits, which are produced throughout the season. A very unusual variety and worthy of the highest recommendation. Pkt. 10c; $1 / 4$ oz. 25c; $1 / 2$ oz. $40 \mathrm{c} ;$ oz $75 \mathrm{c}$; $1 / 4$ lb. $\$ 2.00 ; 1 b . \$ 7.50$.

NEAPOLITAN LARGE EARLY. First brought to this country by a company of Italian market gardeners, this pepper has quickly pushed its way to the front, and is now on a fair way to become the principal shipping pepper of this country. It combines extreme earliness with a most prolific character, and is now the earliest large fruited pepper in cultivation. The first fruits are ready for market the last week in June. Pkt. 10c; $1 / 4$ oz. $25 \mathrm{c} ; 1 / 2$ oz. $40 \mathrm{c} ;$ oz. $75 \mathrm{c} ; 1 / 4 \mathrm{lb}$. $\$ 2.00 ;$ lb. $\$ 7.50$.

LARGE BELL OR BULL NOSE. A very large pepper of square shape, mild, thick and hard. Suitable for stuffing and for mixing pickles. It is less pungent than other sorts, and notwithstanding its size, is one of the earliest. Pkt. 10c; $1 / 4$ oz. 25c; oz. 75 c; $1 / 4$ lb. $\$ 2.00 ; 1 b . \$ 7.50$.

RUBY KING. Fruit of a bright red color, 6 to 7 inches long by about 4 inches through. They are remarkably pleasant and mild in flavor and can be eaten sliced with vinegar, like tomatoes. The best for making mangoes. Pkt. 10c; $1 / 4$ oz. 35 c; oz. 75 c; $1 / 4$ lb. $\$ 2.00 ; 1 b . \$ 7.50$.

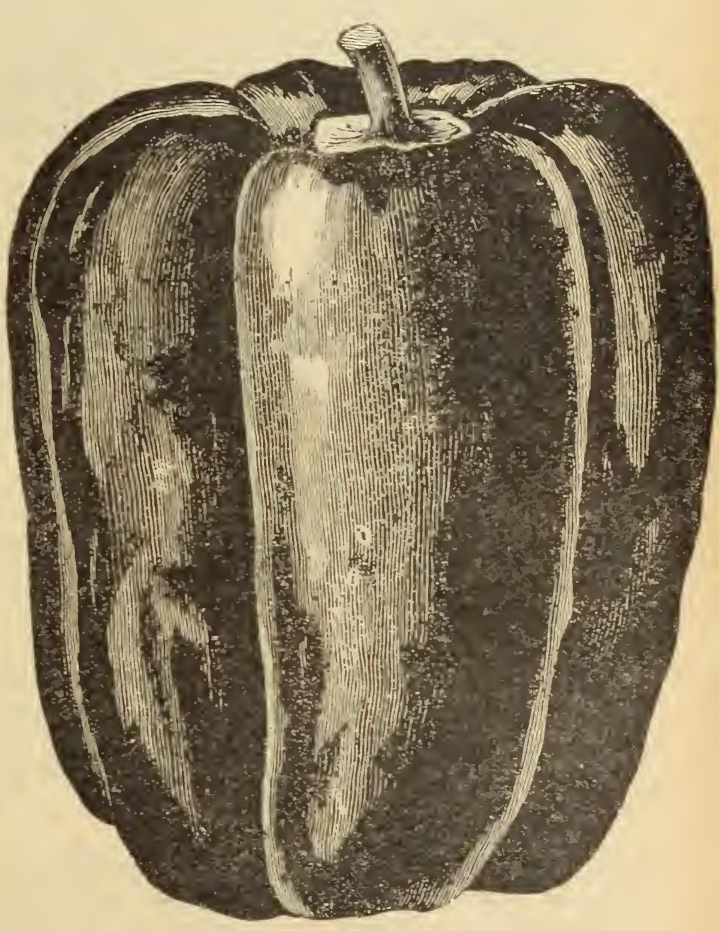

CHINESE GIANT

GOLDEN DAWN. It resembles the popular Bell Pepper in shape. It is of a most handsome appearance, both in growth and upon the table. $\mathrm{Pkt}$. $10 \mathrm{c} ; \mathrm{oz} .75 \mathrm{c}$.

appearance, both in growth and upon the table.

1 PEPPER PIMIENTO. This new pepper is very mild, with thick heary flesh and has a delicate flavor. The shape is very good, being of medium length and smooth. It presents an attractive appearance when filled for the table. It is also delicious when used in salads or creamed like onions. Very prolific and a good shipper. Pkt. 10c; $1 / 4 \mathrm{oz} .15 \mathrm{c} ;$ oz. 50c; $1 / 4 \mathrm{lb}$. $\$ 1.50$. 
ANAHEIM PEPPER. Plants are very vigorous and produce fruits 6 to 8 inches long, tapering from $11 / 2$ to 2 inches in diameter at top to almost a point. When dried they are a brilliant scarlet and are still more pungent than the Black Mexican Chili Pepper. Pkt. 10c; $1 / 2$ oz. 25c; oz. 50c; $1 / 4$ lb. \$1.75.

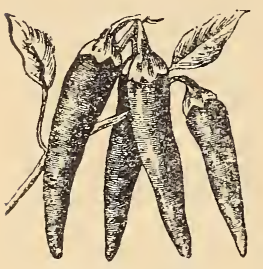

SMALL CHILI

\section{CHILI PEPPERS}

LONG RED CAYENNE. This fruit is a brilliant coral red, conical nad from 2 to 3 inches long and from $3 / 4$ to 1 inch thick. Very pungent. Pkt." 10c; oz. 60c; $1 / 4$ lb. $\$ 2.00$.

CELESTIAL. This pepper has two uses, being both ornamenta and edible The profusely bearing plants produce fruits of constantly changing color. When young they are a creamy yellow and as they mature they become a vivid scarlet. The bushes are an ornament to any garden and the peppers are fine for pickling. Pkt.10 c; oz. 60c; $1 / 4 \mathrm{lb}$. \$2.00.

SMALL RED CHILI. Fruit about 2 inches long and 2-5 of an inch in diameter; red and very hot. Pkt. 10c; oz. 60c; $1 / 4$ lb. $\$ 2.00$.

CHILI PEQUIN. Fruit very small, round, and exceedingly pungent. Used for seasoning and pepper sauce. Pkt. 5c; oz. 40c; $1 / 4$ lb. \$1.40.

\section{Kartoffeln.}

\section{POTATOES}

Patata.

Standard weights of Irish Potatoes 60 pounds per bushel. Please state in case of stock of variety ordered is exhausted, if we shall return the money or substitute an equal value of some near variety. We make special prices on large lots. Write us.

Our potatoes are grown by experienced men, who make a specialty of potatoes for seed. You can depend on our stock. It is usually cheaper to have potatoes shipped in bags on acrount of both the cost of the barrel and the greater weight. We will ship potatoes whenever directed, or u se our best judgment, but in no case will we be responsible for delay or damage in transit.

CULTURE. Potatoes can be grown in any soil provided it is well drained, but if grown on sandy, rich soil they will be better of quality than if planted on clay soil. The sets should be planted from 3 to 4 inches deep, according to the time of planting. in rows 3 feet apart and 16 to 18 inches in the rows. If planted $1 \frac{1}{2}$ by 3 feet there will be about 9,700 hills in one acre, and it will take between 600 and 700 pounds, according to the size of the sets to plant it. At 3 by 3 feet one-half the quantity is sufficient.

TRIUMPH. This beautiful variety combines the wonderful productiveness of the $\mathrm{P}$ eerless with all the good qualities of the Early Rose. Tubers are medium size, round and uniform in shape, with but few small ones; eyes slightly depressed; color a beautiful light red. Its beauty, productiveness and good qualities in general make it one of the best early market varieties, especially for the South, from whence it is shipped to Northern markets, bringing highest prices on account of itsap pearance. $10 \mathrm{lb} .60 \mathrm{c}$.

IRISH COBBLER. One of the most popular of the aerly varieties. Its excellent quality, together with its cream-white color, makes it fine for the best trade. It is a vigorous grower, a good keeper and ripens uniformly. $10 \mathrm{lb}$. $60 \mathrm{c}$.

EARLY SIX WEEKS. Earliest potato in existence and most valuable for market gardeners. A great beauty. Perfect table potato and a wonderful yielder. Ready for market in six weeks, matures in 72 days, two weeks ahead of any other variety and has yielded as high as 400 bushels to the acre. $10 \mathrm{lb} .60 \mathrm{c}$.

$\frac{1}{3}+\frac{1}{2}$

EARLY OHIO. Northern grown, Red River stock. Extra early, and one of the best. It is fit for table use before fully ripe, and can be shipped earlier than any other variety. $10 \mathrm{lb} .60 \mathrm{c}$.

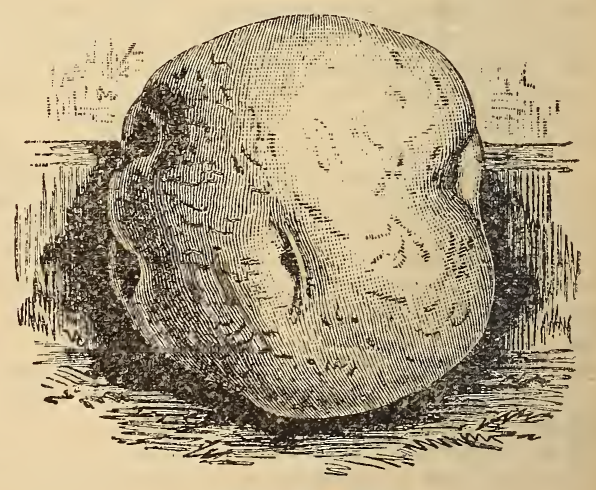

IRISH COBBLER

NORTHERN EARLY ROSE. A popular standard potato noted for earliness, productiveness and fine quality. $10 \mathrm{lb} .60 \mathrm{c}$. 


\section{SWEET POTATOES WRITE FOR PRICES}

CULTURE. Sweet potatoes should be started in a hot bed. When the ground is warm and the danger of frost is past the shoots are carefully lifted and planted in rows three feet apart and eighteen inches in the row. They need considerable care till well started, but after getting a good start will grow easily. They should be cultivated quite of ten, moving the vines to prevent from rooting at the joints. They must be harvested before frost.

Buyers will please note that owing to the tenderness of Sweet Potatoes we do not guarantee the safe arrival of Sweet Potato Plants or seeds; however we use all precautions necessary in packing and time in shipping. Sweet Potatoes cannot be mailed.

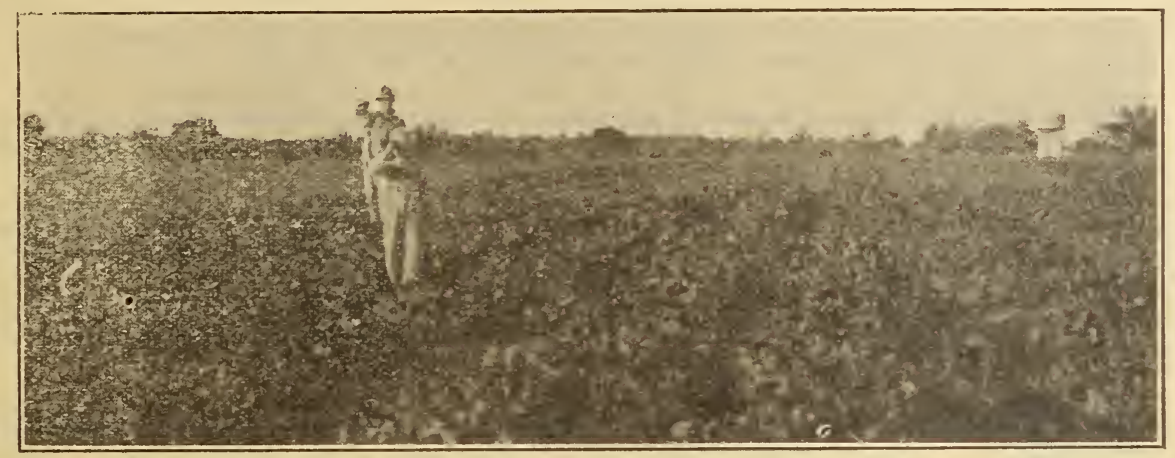

TWO ACRES VINELESS SWEET POTATOES, LEMING TEXAS

Planted May 1918 without irrigation, they stood through the hot summer and the first rain they received was during the latter part of September.

THE VINELESS. We know that every grower wants to improve his stock of Sweet Potatoes. Usually just any kind of Sweet Potatoes have been planted for seed.

In offering our customers this improved variety, which is absolutely first class and free from disease, we know that you will be highly pleased with the results obtained. We have been looking for a high-class Seed Sweet Potatoe for many years and now have something that you will be proud of if you will grow a crop oi them.

The Vineless is the best dry weather sweet potatoe in the country. Lb. 10c.

PRIDE OF TEXAS. Grown alongside of all other varieties known to us, "Pride of Texas outyielded every other sort. The strongest point in favor of the "Pride of Texas is the excellent shape of the tubers. While all the other varieties end in a more or less long, slim neck this sort is rather blunt at both ends. The average specimen measure $S$ inches in circumference in the middle, with 6 to 7 inches in circumference on either end. And we have fre- quently found 8 to 10 tubers fine to a single hill, weighing an average of 10 ounces each. The tubers are of superior appearance having an attractive, russett-yellow $\mathrm{s}$ kin, flesh of a beautiful rich, light salmoz color

PUMPKIN YAM. Taking into consideration quality and productiveness the Yam stands at the head of the list. Frequently when baked the saccharine matter in the shape of candy will be seen hanging to them in strings. Skin and flesh yellow and very sweet. Without a doubt the hest potato for family use. This is the kind mostly planted in the South and is a universal favorite in this section.

BLACK SPANISH. A late variety of fine quality. The skin is of a dark red color, the flesh white. The tubers are of a long shape and keep excellently.

NANCY HALL. A smooth, yeysw skinned yam. Oval, uniform, with deep yellow flesh, which cooks soft and sweet. Early and of fine qulaity.

DOOLEY YAM. Yellow skin and flesh, somewhat similar to the Pumpkin Yam; is very productive and yields a large crop. It is sweet and sugary.

SWEET POTATO PLANTS. We will have plants of the above varieties about May 1st. Prices, packed at San Antonio, per $10050 \mathrm{c}$; per 1,000 \$3.50. If wanted by mail add $15 \mathrm{c}$. per hundred. 
Kurbise

\section{PUMPKINS}

CULTURE. Pumpkins require the same general culture as melons and squashes. As the plants require much space and as they readly mix with cucumbers, melons, etc., they are not very suitable for the home garden. The common practice, and a good one, is to plant the seeds in the corn field, either in hills or between the rows, after the last cultivation. One ounce of seed to thirty hills; 3 pounds to an acre.

KING OF MAMMOTH OR GENUINE MAMMOTH. The flesh and skin are of a bright golden yellow. Flesh fine grained and of excellent quality. Notwithstanding its enormous size, it is one of the very best pie pumpkins ever grown, and a splendid keeper. This enormous variety has been grown to weigh over 200 pounds. Pkt. 5c; oz. 10c; $1 / 4$ lb. 35c; lb. $\$ 1.25$.

SMALL SUGAR. Smaller than field pumpkins, but finer grained, sweeter and very prolific; first rate for the table or stock. The best variety for making pies. Pkt. 5c; oz. 10c; $1 / 4 \mathrm{lb} .30 \mathrm{c} ; 1 \mathrm{lb}$. $\$ 1.00$

LARGE CHEESE. A popular variety in the South. Fruit flattened, the diameter being 2 or 3 times more than the length. Skin mottled green light and yellow changing to rich cream color as it matures; flesh tender and of excellent quality. Pkt. 5c; oz. 10c; 1/4 lb. 25c; lb. 90c.

TENNESSEE SWEET POTATO. A good variety for making pies and other cooking purposes. It is of medium size, of a creamy white color, and has an excellent flavor; good keeper. Pkt. $5 \mathrm{c} ;$ oz. $10 \mathrm{c} ; 1 / 4 \mathrm{lb} .25 \mathrm{c} ; \mathrm{lb} .90 \mathrm{c}$.

COMMON FIELD OR BIG TOM. The well known old Connecticut variety. Grows well among corn; varies in shape. Excellent for feeding dairy stock. Pkt. 5c; oz. 10c;1/4 lb. 30c; 1b. \$1.00.

KENTUCKY FIELD. A large variety, producing pumpkins in abundance. Has thick meat of fine quality. Very suitable for canner's use. Pkt. 5c; oz. 10c; $1 / 4$ lb. 20c; lb. 60c.

MAMMOTH TOURS. A French variety which grows to an immense size, often weighing over 100 pounds. Pkt. 5c; oz 10c; $1 / 4 \mathrm{lb}$. 30c; $1 \mathrm{~b} . \$ 1.00$

JAPANESE PIE. The flesh is very thick, nearly solid; the seed cavity being very small in one end of the pumpkin; fine grained, dry and sweet, having much the taste and appearance of sweet potatoes. They ripen early, keep well, and are fine for home use. The seeds have peculiar marks resembling characters of the Chinese alphabet. Pkt. 5c;oz. 10c; $1 / 2 \mathrm{lb} .30 \mathrm{c} ; \mathrm{lb} . \$ 1.00$.

CUSHAW OR CROOKNECK. A French variety liked by many. Has yellow flesh, solid and sweet. Pkt. 5c; oz. 15c; $1 / 4$ lb. 40c; lb, \$1.50.

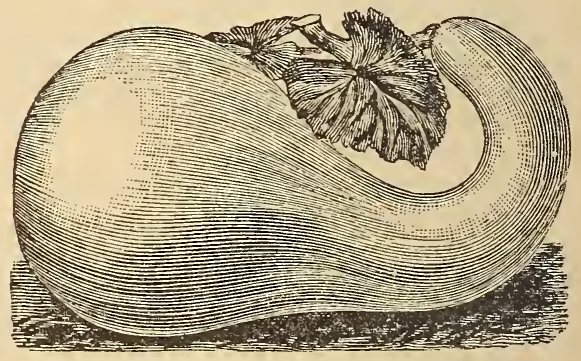

CUSHAW

\section{RADISHES}

\section{Radieschen.}

CULTURE. Sow early in the spring as the ground can be worked, and every two weeks throughout the season for a succession of crops. A warm sandy loam, made rich and light by some good, strong manure, which is thoroughly rotted will be most likely to afford them free of worms and brittle. During summer months use the summer and winter varieties, as the early kind get pithy. Winter Radishes can be wintered over as easily as any root crop and furnish an acceptable relish. One ounce to 100 feet of drill; 10 pounds to the acre.

\section{EARLY ROUND VARIETIES}

ROSY GEM. One of the earliest varieties in cultivation. It is of perfectly globular shape, of rich color, being deep scarlet on top, blending to pure white at the bottom. The radishes are exceedingly tender and crisp and delicious. Desirable for growing under glass as well as in the open ground. Pkt. 5c; oz. 15c; $1 / 4 \mathrm{lb} 50 \mathrm{c} \cdot \mathrm{lb}$. \$1.50. 


\section{RADISHES-Continued.}

EARLY SCARLET GLOBE. This variety makes roots fit to pull as early as Non-Plus-Ultra, but they are much larger when full size, and for this reason are very popular in some markets. Roots round or slightly oval shaped; color rich, deep scarlet, flesh white and tender. Pkt. 5c; oz. 15c; $1 / 4$ lb. 50c; lb, $\$ 1.50$.

EARLY ERFURT DARK ROUND RED OR DEEP SCARLET TURNIP. This is a splendid strain of the small extra early, round radish, it is ready for use in 18 to 20 days after sowing. The radishes are very attractive, tender and mild flavor. The tops are small, hence it is an excellent variety for growing under glass Pkt. 5c; oz. 15c; $1 / 4$ lb. 50c; lb. $\$ 1.50$.

EARLY SCARLET TURNIP. A small, sound, red turnip shaped radish with a small top, and of very quick growth. Pkt. 5c; oz. 15c; $1 / 4$ lb. 50c; lb. $\$ 1.50$.

EARLY WHITE TURNIP. Both skin and flesh are white. It is a few days later than the Scarlet Turnip, and will bear heat without becoming pithy. Pkt. 5c; oz. 15c; $1 / 4 \mathrm{llb} .50 \mathrm{c} ; \mathrm{lb} . \$ 1.50$.

CRIMSON GIANT GLOBE. This new radish is an entirely new type, and differs from all the varieties hereto in cultivation, in so far that its roots attain more than double the size of thise of other forcing varieties without getting pithy or hollow. This giant radish develops roots 6 to 8 inches in circumference and over an ounce in weight, their pure white flesh remaining firm and crisp, and of mildest flavor. Notwithstanding the extraordinary size and weight of its bulbs, it is second to none as a forcing variety. It's equally well adapted to outside culture. The seeds should be sown thinly to permit full development of the roots. Pkt. $5 \mathrm{c} ;$ oz. $15 \mathrm{c} ; 1 / 4 \mathrm{lb} .60 \mathrm{c} ; \mathrm{lb} . \$ 2.00$.

NON PLUS ULTRA. By far the smallest-topped and earliest forcing radish in cultivation. Roots small, round, deep red, with very crisp, tender white flesh. This is the very best variety for forcing. as it will mature in 18 to 21 days and the tops are so small that a large number can be grwn in a single bed. Pkt. 5c; oz. 15c; $1 / 4$ lb. 50c; lb. $\$ 1.50$.

SCARLET TURNIP, WHITE TIPPED. A beautiful variety deep scarlet with white tip. It is very ornamental for table use, and is becoming very popular as a market variety. It is of the same size and shpae as the scarlet turnip variety. Pkt. 5c; oz. 15c: $1 / 4 \mathrm{lh} .50 \mathrm{c}$; lb. $\$ 1.50$.

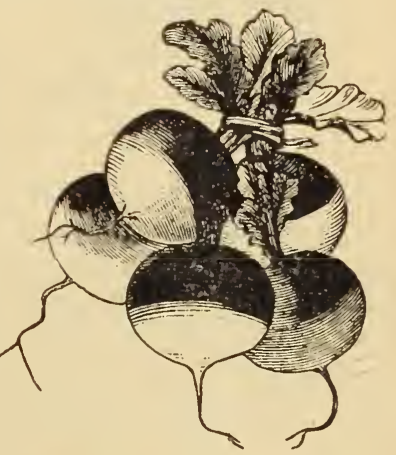

Scarlet Turnip, White Tipped.

\section{OLIVE-SHAPED VARIETIES}

FRENCH BREAKFAST. A medium-sized radish with smal top. Quick growth and very crisp and tende. ${ }_{2}$. Pkt. 5c; oz. 15c; $1 / 4$ lb. 50c; lb. $\$ 1.50$.

EARLY SCARLET OLIVE SHAPED. Very early and handsome. Lovely rose color, oblong shaped, top very small. Pkt. 5c; oz. $15 \mathrm{c} ; 1 / 4 \mathrm{lb}$. 50c; lb. \$1.50.

CINCINATTI MARKET. An improved Long Scarlet Short Top, the ronts being more perfect in shape and excellent for forcing. Pkt. $5 \mathrm{c} ;$ oz. $15 \mathrm{c} ; 1 / 4 \mathrm{lb} .50 \mathrm{c} ; \mathrm{lb} . \$ 1.50$

\section{SUMMER VARIETIES}

All of the following varieties attain a larger size than do any of the ear ier radishes. While not ready for the market quite so early they remain in fine condition longer without becoming pithy.

WHITE DELICIOUS RADISH. Not since the now popular "Icicle" Radish was brought to us from Germany years ago have we found such an excellent radish as the "White Delicious," which we now offer to "Southern Planters." "White Delicious" is particularly adapted for summer use, producing handsome olive-shaped roots, which are pure white, exceedingly crisp and cf mild flavor. "White Delicious" requires a longer time to mature than the earlier varieties of Radishes, but it remains in condition much longer. It is altogether the most desirable variety for summer use and we are sure our customers will like it. Pkt $10 \mathrm{c} ;$ oz. $20 \mathrm{c} ; 1 / 4 \mathrm{lb} .70 \mathrm{c} ; \mathrm{lb} . \$ 2.50$.

Ib. \$2.00.

CHARTIERS OR SHEPHERD. Long Scarlet tipped with white. Pkt. 5c; oz. 15c; $1 / 4 \mathrm{lb} .55 \mathrm{c}$; 


\section{RADISHES-Continued}

LONG WHITE VIENNA OR LADY FINGER. A rapid grower of fine shape. Pkt. 5c; oz. 15c $1 / 4$ lb. 50c; lb. $\$ 1.50$.

YELLOW SUMMER TURNIP. A general favorite with market gardeners. Pkt. 5c; oz. 15c; $1 / 4$ lb. 50c; lb. $\$ 1.50$.

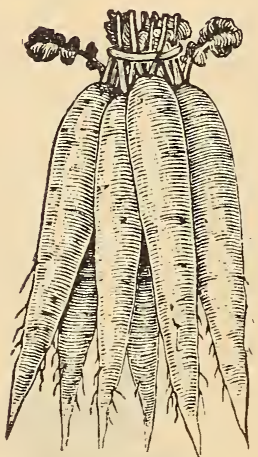

WHITE ICICLE

\section{LONG VARIETIES}

GLASS RADISH. The radish comes from the same gardener in Denver who originated the Denver Market Lettuce, and is a fine acquisition. It is a long radish of light pink color, white tipped, of uniform size. The flesh is transparent white, always crisp and brittle, even if grown to a large size, and mild flavored. It was named "Glass Radish" on account of fine transparency of the flesh. Pkt. 5c; oz. 15c; $1 / 4$ lb. 55c; lb. \$2.09.

HALF LONG DEEP SCARLET. The roots of this hardy and desirable variety are of a very brilliant, deep rich color, and half long, with somewhat tapering points, the flesh is white, crisp and tender, and holds its juiciness very well not becoming pitly until overgrown. Pkt. 5c; oz. $15 \mathrm{c} ; 1 / 4 \mathrm{lb} .50 \mathrm{c} ; \mathrm{lb} . \$ 1.50$.

EARLY SCARLET SHORT TOP. Is undoubtedly the best standard variety for private garden and market use. It grows 6 or 7 inches long, half out of the ground. It is very brittle and crisp and of quick growth. Color bright scarlet, small top, tapers regularly to the root, and is uniformly straight and smooth. Pkt. 5c; oz. 15c; $1 / 4$ lb. 5ic; lb. $\$ 1.50$.

SAKURAJIMA RADISH. This Japanese curiosity is the largest of the oriental winter radishes. It is a white variety of a good quality and mild flavor, attaining a length of 2 feet, and a diameter of 1 foot or more. Should be sown in February in drills 2 feet apart and thinned to 1 foot apart in the rows. If sown in the spring the winter radishes are apt to go to seed and form no root. In China and Japan they are most commonly eaten cut in chunks and pickled in brine; also sliced or shredded when fresh. Pkt. 10c; oz. 20c.

WHITE ICICLE. An entirely distinct long, slender pure white variety. It is without doubt the earliest and finest long white Radish in existence. Ready for use fully as early as Long Scarlet Top, with less foliage, rendering it most desirable for forcing. In the open ground the roots continue brittle, crisp and mild until they are fully as large as those of the Long Bright Scarlet. The Icicle is perhaps superior to the finest long red ones. Roots four inches in length and half an inch in diameter; they retain their crispness and fresh, mild flavor until fully 6 inches long and an inch in diameter. Pkt. 5c; oz. 15 c; $1 / 4$ lb. 55c; lb. $\$ 2.00$.

WOOD'S EARLY FRAME. Of the "Long Scarlet" type, not quite so long and a little thicker, the brilliant scarlet color, mild, brittle, of fine flavor, and the most suitable for forcing and the early market garden. Pkt. 5c; oz. 15c; $1 / 4 \mathrm{lb}$. $50 \mathrm{c} ; \mathrm{lb}$. $\$ 1.50$.

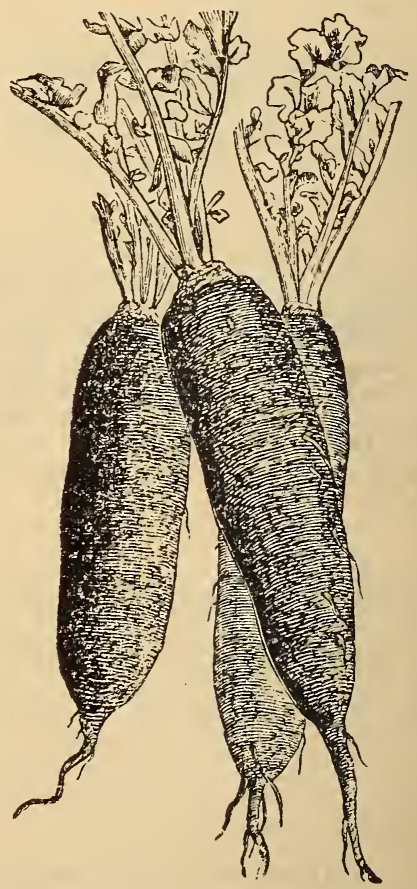

LONG BLACK SPANISH 


\section{WINTER RADISHES}

These can be divided into two distinct varieties; the European varieties and the Chinese or California varieties. The former have firm, hard, but very fine grained flesh, while the latter produce

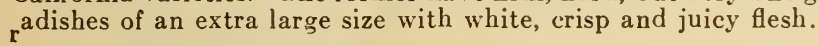

The Long Black Spanish and the Round Black Spanish are the favorite German Winter "Rettige."

The White Chinese is the finest of all extra large white radishes. Nearly the whole of the splendid root grows above the surface, which makes pulling them a pleasure. The flesh is always crisp and juicy.

The China Rose-colored, and the California Mammoth White are quite similar to the above, but not quite so large.

LONG BLACK SPANISH. An excellent keeper. Pkt. 5c; oz. 15c; 1/4 lb. 55c; lb. $\$ 2.00$.

ROUND BLACK SPANISH. Fine for winter use. Pkt. $5 \mathrm{c} ; \mathrm{oz} .15 \mathrm{c} ; 1 / 4 \mathrm{lb} .55 \mathrm{c} ; \mathrm{lb} . \$ 2.00$.

WHITE CHINESE OR CELESTIAL. Cultivated extensively by market gardeners. Pkt. 5c; oz. $15 \mathrm{c} ; 1 / 4 \mathrm{lb} .55 \mathrm{c} ; \mathrm{lb} . \$ 2.00$.

CHINA ROSE COLORED. Not as strong as the "Spanish" Radishes. Pkt. 5c; oz. 15c; $1 / 4$ lb. $55 \mathrm{c} ; \mathrm{lb} . \$ 2.00$.

CALIFORNIA MAMMOTH WHITE. Grows from $S$ to 12 inches long. Pkt. 5c; oz. 15c; $1 / 4$ lb. 55c; lb. $\$ 2.00$.

\section{RHUBARB OR PIE PLANT}

Rhobarbar.

Ruibarbo.

CULTURE. Rhubard succeeds best in deep, somewhat retentive soil. The richer its condition and the deeper it is stirred the better. Sow in drills an inch deep and thin out the plants to 12 inches apart. The following spring transplant in place; set the plants from 4 to 5 feet each way. One ounce produces from 400 to 500 plants. Book, "Rhubarb Culture, ' by J. E. Morse, price 50c.

LINNAEUS. Early, large and tender. Pkt. 5c; oz. 15c; $1 / 4$ lb. 45c; lb. $\$ 1.50$.

VICTORIA. The most popular variety, later than the preceeding. Pkt. 5c;oz. 15c; $1 / 4 \mathrm{lb} \quad 5 \mathrm{c}$; lb. \$1.50.

AUSTRALIAN CRIMSON WINTER. Luther Burbank's introduction. Can be grown indoors in winter time. $\mathrm{Pk} .10 \mathrm{c} ;$ oz. $50 \mathrm{c} ; 1 / 4 \mathrm{lb}$. $\$ 1.50$.

\section{RHUBARB ROOTS}

LINNAEUS and VICTORIA. 2 for $25 c ; 5$ for $50 c ; 12$ for $\$ 1.00$; charges prepaid. If by freight or express not prepaid 85c per dozen; \$5.00. per 100 . 


\section{SALSIFY, OR OYSTER PLANT.}

Haferwurzel.

Salsif.

CULTURE. The Oyster Plant succeeds best in some light. well enriched soil which previous to sowing in seeds should be stirred to the depth of 18 inches. Sow early in the spring in drills 15 inches apart; cover the seeds with fine soil 1 inch deep. One oz. for 60 feet of drill; 5 pounds to one acre.

MAMMOTH SANDWICH ISLAND. This splendid variety grows to fully double the size of the old sort; is of superior quality and delicate flavor. The Oyster Plant is one of the most nutritious and delicious vegetables, and should be more generally cultivated for winter use when the supply of really good vegetables is limited. No Market Gardener should fail to grow it. It is a paying propostion. Pkt. 5c; oz. 20c; $1 / 4$ lb. 75c; lb. \$2.85.

\section{SPINACH}

Epinard (Fr.), Spinat (Ger.), Espinago (Sp.), Spinace (Ital.).

CULTURE. A great deal of this is raised for the Northern market. It is very popular. Sown from September to the end of March. If the Fall is dry and hot it is useless to sow it, as the seeds require moisture and cool nights to make them come up. The richer the ground the larger the leaves. One ounce to 150 feet of drill; 8 pounds to the acre.

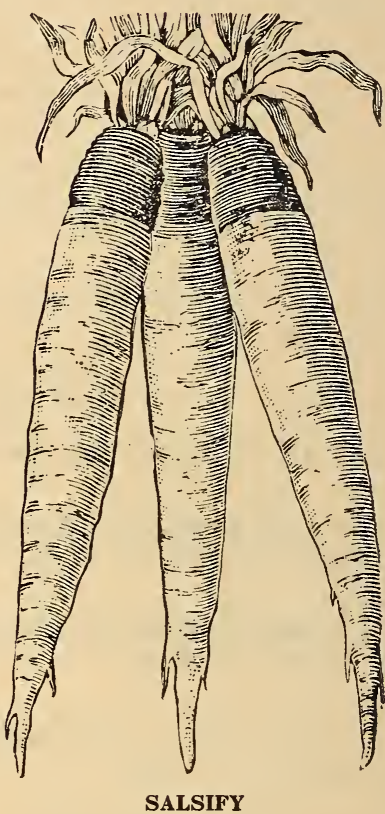

TRUE VICTORIA. The foliage is heavy, the broad dark leaves being of the true Savoy appear. ance and are of the finest quality. The feature that makes it of especial value for both market and family gardens, is that it is in prime condition from two to three weeks after all other varieties of Spinach have run to seed. Pkt. 5c; oz. 10c; $1 / 4$ lb. 30c; lb. $\$ 1.00$.

BLOOMSDALE. A most valuable variety. In appearance the leaf is wrinkled in the same way as that of the Savoy Cabbage, hence the name. It produces nearly twice the bulk of crop as the ordinary sort, is fully as hardy and in all other respects equal. Pkt. 5c; oz. 10c; $1 / 4$ lb. 30c; lb. $\$ 1.00$.

NEW ZEALAND.

(Tetragonia expansa.) This is not a Spinach of the ordinary kind, but a plant of branching growth One single plant will grow to dimensions of six feet across, producing an abundance of thick, fleshy. juicy stems, and leaves, which make an excellent Spinach. The flavor is fine and the fact that it does well throughout the hottest summer, makes it all the more desirable. Every Market Gardener should grow a crop where there is a market for Spinach. It is a money maker. Pkt. $5 c ;$ oz. 15c; $1 / 4$ lb. 50c; lb. $\$ 175$.

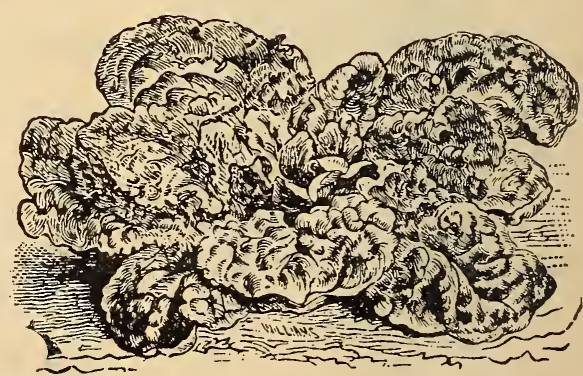

BLOOMSDALE SPINACH 


\section{SPINACH-Continued}

ROUND SUMMER. This variety is generally preferred for early spring growing, and is popular with market gardeners. Leaves thick and fleshy. Not quite as hardy as the prickly, but stands winter well. Pkt. 5c; oz. 10c; $1 / 4$ lb. 30c; lb. $\$ 1.00$.

PRICKLY OR WINTER. The hardiest variety and will withstand the severest weather with only a slight protection of straw or leaves. The seed is prickly, leaves triangular, oblong or arrow shaped. It is the best for fall sowing, which in this latitude is about the first of September. Pkt. 5c; oz. 10c; $1 / 4$ lb. 30c; lb. $\$ 1.00$.

LONG STANDING. An improved $\mathrm{st}^{\mathrm{r}}$ ain of excellent merit, having all the good qualities of the ordinary sorts; but it is especially desirable because of the fact that it is much later in going to seed than the average variety. Pkt. 5c; oz. 15c; $1 / 4$ lb. 50c; lb. $\$ 1.75$.

\section{SQUASHES}

\section{Speise Kurbise.}

Calabazs.

Squashes are divided into two classes; the early summer sort and the late fruited winter varieties Sow about the middle of spring in hills, the early sort about 4 feet apart, and the late varieties 6 to 8 feet. Drop enough seed to be thinned to three plants in a hill. The hills should be highly manured and prepared in a similar manner as those for cucumbers. One ounce to 40 hills for small sorts; large varieties 1 ounce to 20 hills; 3 to 4 pounds to the acre.

BUG DEATH kills all kinds of bugs and does not injure the foliage. Include some with your order. You will need it later.

\section{SUMMER VARIETIES}

EARLY WHITE BUSH. This is the well known White Patty-pan squash. The earliest to mature, very productive; light cream colored. Pkt. 5c; oz. 10c; $1 / 4$ lb. 30c; lb. $\$ 1.00$.

MAMMOTH WHITE BUSH. The fruit is a beautiful white wax instead of the yellowish white so of ten seen in the old stock, and is much larger. Pkt. 5c; oz. $10 \mathrm{c} ; 1 / 4 \mathrm{lb}$. 30c; lb. $\$ 1.00$.

GOLDEN SUMMER CROOKNECK. A small crookneeked summer squash; skin bright yellow, covered with warty excrescenses. Very early, productive and of excellent flavor. Pkt. $5 \mathrm{c} ;$ oz. $10 \mathrm{c} ; 1 / 4.1 \mathrm{~b} .35 \mathrm{c}$; lb. $\$ 1.25$.

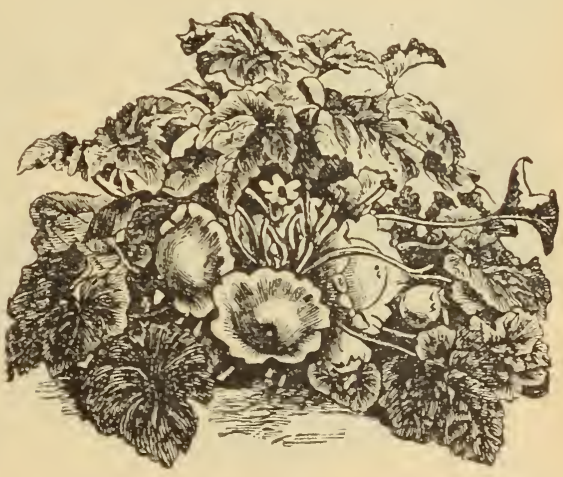

EARLY WHITE BUSH

MAMMOTH SUMMER CROOKNECK. One of the best summer Squashes. It is twice as large as the ordinary Summer Crookneck, highly attractive, several days earlier. This combination of earliness and size make it a most desirable variety for the market gardener as well as for private use. Pkt. 5c; oz. 10c; $1 / 4$ lb. 35c; lb. \$1.25.

HUBBARD. The best table Squash yet known, rivaled only the "Delicious," Good specimens are about equal to the sweet potato. It has a hard shell, and with some care will keep three months longer than the Marrows. Flesh fine grained, dry and of excellent flavor. Pkt. 5c; oz. 10c; $1 / 4$ lb. 35c; lb. \$1.25.

THE WARTED HUBBARD. This is, in quality, one of the best winter sorts. It is attractive on the market and a ready seller. Very dark green, and flesh is dry and sweet. Very hard shell, which insures good keeping qualities. It is considered an improvement on the old type of Hubbard on account of it warted skin. Pkt. 5c; oz. 10c; $1 / 4$ lb. 35c; lb. \$1.25.

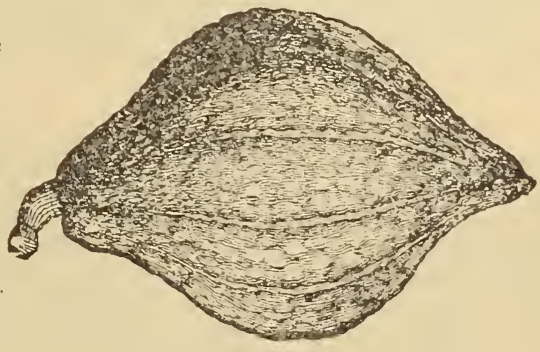

HUBBARD SQUASH 


\section{SQUASHES-Continued}

GREGORY'S DELICIOUS. This fine new winter squash, now offered by us to the Western Planters is of the finest quality possible. The Eastern people have had it for the past few years, and the popularity of this splendid variety increases steadily. In size it closely resembles the original Hubbard. In color it is almost uniform with occassionally a blue specimen. The thickness of its flesh surpasses nearly every other variety; the color being a dark orange. For table use it cannot be excelled; these Squashes represent a remarkable combination of fineness and compactness of grain, dryness, sweetness and exceeding richness of flavor. Pkt. 5c; oz. 10c; $1 / 4$ lb. 35c; lb. \$1.25.

BOSTON MARROW. Oval in form, color of skin bright orange, flesh yellow, very desirable for late autumn and winter use. Pkt 5c; oz. 10c; $1 / 4$ lb. 35c; lb. \$1.25.

ENGLISH CREAM MARROW. It is as sweet as a sweet potato, and has none of that pumpkin flavor. It is good any way it comes on the table, and is better than Hubbard Squash for pie. It is 6 to 8 inches long and half as thick. Decidedly firm, it will keep from one season to a nother. Pkt. 10c; oz. 15c; $1 / 4$ lb. 50c; $1 / 2$ lb. 85c; lb. $\$ 1.50$.

VEGETABLE MARROW. A favorite English sort; early, skin greenish-white, flesh white, soft and of rich flavor; quite distinct from other sorts. Pkt. 5c; oz. 10c; $1 / 41 \mathrm{lb} .35 \mathrm{c} ; 1 \mathrm{lb}$. \$1.25.

ACORN. Every home garden should have a few hills of this delicious squash. For table use or for pies it is unsurpassed, uniform in shape and bright red color makes it a desirable ornament for the table.

Recipe. Remove the blossom end, take out all the seed, and bake in an oven. When baked, remove the edible portion, season and serve in the shell. Pkt. 5c; oz. 30c; $1 / 4 \mathrm{lb} .80 \mathrm{c}$.

Tabak.

\section{TOBACCO}

CULTURE. Tobacco in this part of the country should be started in a hot-bed in February and treated the same as tomatoes.

HAVANA. Pure Cuban grown seed. When grown in this country commands a high price as cigar stock. Pkt. 5c; oz. 50c; 1/4 lb. $\$ 1.50$.

MISSOURI BROAD LEAF. A well known standard sort, valuable for cigar wrappers. Pkt. 5c; oz. 50c; $1 / 4$ lb. $\$ 1.50$.

CONNECTICUT SEED LEAF. Best adapted to the climate of the Middle and Northern States, and it is more hardy and endures the cold better than the tender varieties grown in the South. Pkt. 5c; oz. 50c; $1 / 4$ lb. $\$ 1.50$.

WHITE BURLEY. A variety grown for the manufacture of fine cut and plug. Pkt. 5c; oz. 50c; $1 / 4 \mathrm{lb} . \$ 1.50$.

\section{TOMATOES}

Tomaten oder Liebesapfel.

Tomato.

CULTURE. The seed should be grown in January in a hot bed or green house, or may be sown in a box and kept inside the window of a room where the night temperature is not less than 65 degrees. The plants should be thinned out in the bed so as to give them plenty of room or they will be weak and poor. They should be hardened before planting outside. About the middle of April the plants may be set in the open ground. from 4 to 5 feet apart each way. Our stock of tomatoes is grown by several of the best growers. One ounce produces about 1,500 plants.

To prevent rot and blight on tomato plants spray with Bordeaux mixture, when first fruits have set. If disease appears repeat or use a weak Copper Sulphate solution as often as needed.

KANSAS STANDARD. The Kansas Standard belongs to the potato leaved class of to matoes; it is of rapid, vigorous growth, with strong heavy stalks, which stand up well unless, which is often the case, they are pulled down with over-abundant fruit. It begins by blooming when only six or seven inches high, attains a height of from two and a half to three feet and gets its fruit - a rare habit in any tomato-from the first blooms. The fruit is of a bright glossy red color and is produced in clusters of from four to five tomatoes. In shape the fruit is round, slightly flattened, ripening clear to the stem, perfectly smooth. It has few seeds; the meat is thick and firm and if a most excellent flavor. This tomato is a first-rate keeper and shipper on account of its tough skin, a fact which makes it also very resistable against influences of insects. which are so destructive to other varieties. Highly r ecommended. Pkt. 5c; oz. 40c; $1 / 4 \mathrm{lb}$. $\$ 1.50 ; \mathrm{lb}$. $\$ 5.50$. 


\section{TOMATOES-Continued}

THE NEW “JUNE PINK" TOMATO. Undoubtedly,the best pink-fruited early Tomato on cultivation. It is fully as early as "Spark's Earliana," of high productiveness and the vines are absolutely blight proof. The splendid round, solid, meaty Tomatoes are the attraction of the markets, and when bright red varieties were bringing $\$ 1.25$ to $\$ 1.50$ per crate. "June Pinks" sold for $\$ 2.25$ to $\$ 2.50$. The plants are very thrifty, making a vigorous growth. The fruits are usually set in large clusters and run from $21 / 2$ to $31 / 2$ inches in diameter. They stand shipping exceedingly well and bring highest prices wherever offered. The Tomatoes are solid, free from core, have only few seed cavities and the meat is of fine flavor. "June Pink" is altogether the most desirable pink variety of first crop. It will, we are sure, be a great "money maker" for truckers. Pkt. 10c; $1 / 2$ oz. 25c; oz. 40c; $1 / 4 \mathrm{lb}$. $\$ 1.50$; lb. $\$ 5.50$.

EARLIANA. This is without doubt the earliest bright red tomato now in cultivation. The tomatoes are deep scarlet and grow closely together in clusters of five to eight. They are of medium size, smooth and solid. The plants are quite hardy' with rather slender branches, bearing an abundance of fine tomatoes. The close dwarf habit of growth makes it very desirable variety, where not much space can be wasted on a more spreading and branching variety. It is especially valuable as it produces fruit at the time when the prices are the highest. No market gardener should be without it. Pkt. 5c; oz. 35c; $1 / 4$ lb. $\$ 1.20$; lb. $\$ 4.00$.

\section{CHALKS EARLY JEWEL TOMATO}

Of most handsome appearance, finest flavor and early ripening qualities, this new bright red Tomato is destined to become a leader among the already numerous popular varieties. In time of ripening it is within a week or ten days later than "Spark's Earliana", the well known earliest of all bright red tomatoes. The extremely handsome fruits are of the finest table qualities, possessing remarkably sweet flavor. They are solidly meaty, having small carities and are not apt to crack. The plants are of robust growth. strong, producing fruits throughout the season and for this reason we recommend to plant "Chalk's Jewel" not only for an early crop producer, but as one which may be planted as a main crop as well. Pkt. $10 \mathrm{c} ; 1 / 2 \mathrm{oz} .15 \mathrm{c}$;

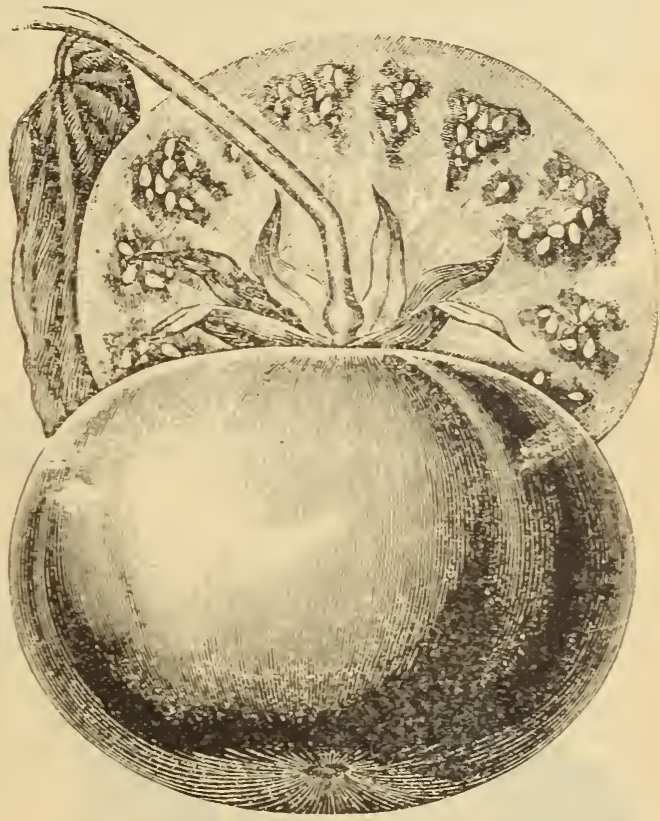

EARLIANA oz. $35 \mathrm{c} ; 1 / 4 \mathrm{lb}$. $\$ 1.20$; lb. $\$ 4.00$.

THE MATCHLESS. For the past twenty years Matchless has been the main crop variety, and in spite of many new varieties, claiming superiority, has maintained int sposition as the finest large fruited, bright red variety. The vines are of strong, vigorous growth, well set with fruit. The fruits are free from core, of a very rich cardinal red color and are not liable to crack from wet weather. They are of very large size and the size of the fruit is maintained throughout the season until the vines are killed by frost. The skin is remarkable tough and solid, and ripe specimens picked from the vines will keep in good condition for several weeks. Our stock of Matchless is absolutely unsurpassed Pkt. 5c; oz. 35 c; $1 / 4$ lb. $\$ 1.20 ; \mathrm{lb}$. $\$ 4.00$.

LIVINGSTON'S GLOBE TOMATO. A most popular tomato with Texas shippers. Our seed of this variety is grown from Livingston's original strain and kept absolutely pure. We find it one of the earliest. Fruits are smooth and of good size; firm flesh and few seeds. Very productive of fruit being short jointed, and clusters of fruit form at each joint. Fruits are of right size and shape to pack well for shipment Color of skin purplish red, about the same shade as our Redfield Beauty Our experience with this variety both in our own crops and by observation of market gardens in several states is that about one-hlaf of the fruits come true globe shaped; the balance are either flattened, but much thicker, proportionately, than other varieties. Pkt. 10c; 1/2 oz. 35c; oz. 65c; $1 / 4$ lb. $\$ 2.40 ; 1 b . \$ 8.50$. 


\section{TOMATOES-Continued}

THE TRUCKER'S FAVORITE. This, in our estimation, is the "Pereless" amongst the pink tomatoes. A variety of such unusual merit that it deserves the highest praise and recommendation. It is truly "The Trucker's Favorite." Its fine and smooth uniformly shaped fruits command the highest market price and when once a market has found out the meritorious characteristics of this splendid sort, it cannot do without it.

The fruits are thick meated and very solid; the meat is of the finest flavor, making the tomatoes equally good for slicing and for cooking purposes. A basket of these tomatoes is one of the most attractive sights on the market table, and parties offering them for sale will find the demand larger than the supply. Be sure to include this variety in your next order. You will want more seed next year. Pkt. 5c; oz. 35c; 1/4 lb. $\$ 1: 20 ; \mathrm{lb}, \$ 4.00$.

McGEE. Originated by M. C. McGee, San Marcos, Texas. Claimed to yield splendid crops where other varieties fail. Bright crimson in color, solid and of good flavor. Pkt. 50c.

ACME. A tomato of superior quality; of medium size and slightly oval in shape. Flesh deep scarlet and unusually solid. Grows very regular. Pkt. 5c; oz. 35c; $1 / 4$ lb. $\$ 1.20$; lb. $\$ 4.00$.

BEAUTY. It grows in clusters of four or five large fruits, retaining its large size very late in the season. It ripens very early and evenly, and is in perfect shape. Pkt. 5c; 07. 35c; $1 / 4$ lb. $\$ 1.20$; lb. $\$ 4.00$.

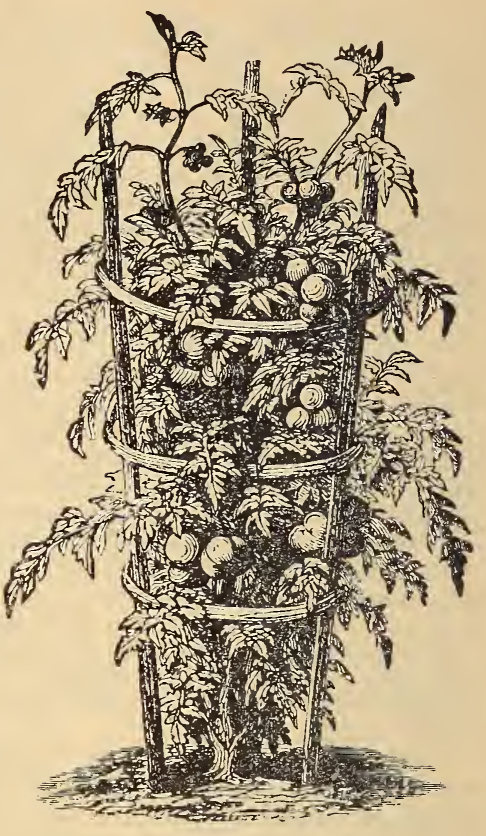

THE TRUCKER'S FAVORITE

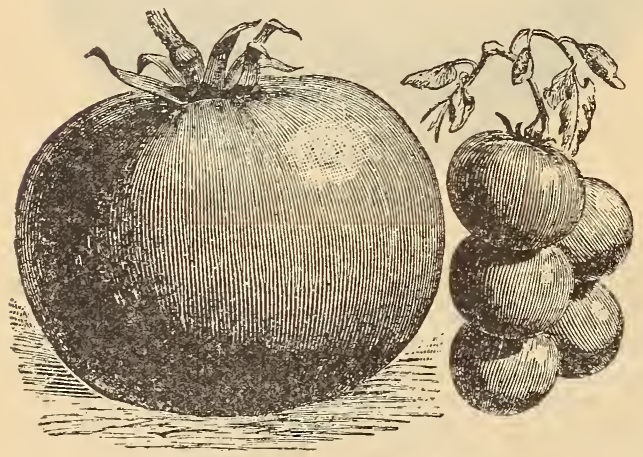

DWARF CHAMPION
DWARF CHAMPION, Its close, upright growth enables it to be planted much earlier and nearer together than any of the older sorts, and the yield, therefore, is accordingly much greater. In productiveness it is unsurpassed. It is also very early. The fruit resembles the Acme, and is of a purplish pink color, and always smooth and symmetrical in form. It is medium size and attractive in appearance; the skin is tough and the flesh solid and of fine quality. Pkt. 5c; oz. 35c; $1 / 4$ lb. $\$ 1.20 ;$ lb. $\$ 4.00$.

GOLDEN PONDEROSA. There are several varieties of Yellow Tomatoes on the market, but most of them are valuable only on account of their yellow color. The Golden Ponderosa has all the good qualities of the Red Ponderosa, and in addition has a striking yellow color, which makes it very attractive.

It is a heavy yielder and the tomatoes are of very large size and of a delicious flavor. Excellent for slicing and when the slices are served on a dish with slices of red tomatoes the effect is very pretty and attractive. Pkt. 10c; oz. 40c.

EARLY DETROIT. This is a splendid variety introduced five years ago, is claimed to be the earliest and the best of the Early Purplish Pink Tomatoes. Vine vigorous and very productive. Fruits very smooth and uniform in size, nearly globe shape, firm and of excellent quality. It is used almost exclusive by the truckurs around Corpus Christi and Engleside, Texas for early shipping One of the most valuable shipping tomatoes yet produced. Pkt. 10c; oz. 45c; $1 / 4 \mathrm{lb}$. $\$ 1.60$. $1 \mathrm{~b}$. $\$ 5.50$. 


\section{TOMATOES-Continued}

PONDEROSA. The Giant among Tomatoes. The fruit is extra large and fine for slicing. If you want Big Tomatoes, plant Ponderosa. Pkt. 5c; oz. 50c; $1 / 4$ lb. $\$ 1.75 ; 1 b . \$ 6.00$.

FAVORITE. Has no green core, of perfect shape, smooth as an apple and never cracks after ripening. Pkt. 5c; oz. $35 \mathrm{c} ; 1 / 4$ lb. $\$ 1.20 ; 1 \mathrm{~b} . \$ 4.00$.

\section{YELLOW AND SMALL-FRUITED VARIEITES}

GOLDEN QUEEN. The best yellow variety. Of superior appearance and a distinct flavor of its own. Pkt. 5c; oz. 40c; $1 / 4$ lb. $\$ 1.50 ; 1 b . \$ 5.50$. lb. $\$ 5.50$.

YELLOW PLUM. Color bright yellow; excellent for preserving. Pkt. 5c; oz. 40c; $1 / 4$ lb. \$1.50;

RED PLUM. Same as above except color. Pkt. 5c; oz. $40 ; 1 / 41 b . \$ 1.50 ; 1 b . \$ 5.50$.

RED PEAR, A small variety, early; fine for preserving. Pkt. $5 \mathrm{c} ;$ oz. $40 \mathrm{c} ; 1 / 4 \mathrm{lb} . \$ 1.50 ; 1 \mathrm{~b} . \$ 5.50$

YELLOW PEAR. Same as above except color. Pkt. 5c; oz. 40c; 1/4 lb. \$1 :50; 1b. \$5.50.

RED CHERRY. A small variety, size and shape of a cherry; for pickling. Pkt. 5c; oz. 40c; $1 / 4$ lb. $\$ 1: 50 ; 1 b . \$ 5.50$.

YELLOW CHERRY. Same as above, except color. Pkt. 5c; oz. 40c; $1 / 4$ lb. $\$ 1.50 ; 1 b . \$ 5.50$.

HUSK TOMATO or GROUND CHERRY. This very fine for preserves; immensely productive ${ }^{\circ}$ Pkt. 5c; oz. 40c; $1 / 4$ lb. $\$ 1.50 ; 1 b . \$ 5.50$.

\section{TURNIPS}

Navet (Fr.); Ruebe (Ger.); Nabo Comun (Sp.); Navone (Ital.).

CULTURE. Turnips do best in new ground. When the soil has been worked long, it should receive a top dressing of ashes. If stable manure is used the ground should be manured the Spring previous to sowing, so it may be well incorporated with the soil. When fresh manure is used the Turnips are apt to become speckled. Sow from end of July to October for Fall and Winter, and in January, February and March for Spring and Summer use. They are generally sown broadcast, but the Ruta Baga should be sown in drills, or rather ridges, and should not be sown later than the end of August; the Golden Ball and Aberdeen not later than the end of September. The Early White Flat Dutch, Early Egg and Pomerian Globe are the best for Spring, also good for Autumn. One ounce to 260 feet of drill; $1 \frac{1}{2}$ pounds to the acre.

\section{WHITE FLESHED VARIETIES}

EARLY SNOWBALL. Is medium sized, pure white and early, of excellent quality. In our market it is much admired. Pkt. 5c; oz. 15c; $1 / 4$ lb. 55c; lb. $\$ 2.00$.

EXTRA EARLY PURPLE TOP MILAN. The earliest in cultivation. The bulb is very flat, of medium size, quite smooth with a bright purple top. Pkt. 5c; oz. 15c; 1/4 1b. 60c; lb. \$2.25.

EXTRA EARLY WHITE MILAN. Very similarto the preceding except the skin is pure white, thus making it especially desirable for forcing. Pkt. $5 \mathrm{c}$; oz. 15c; $1 / 4 \mathrm{lb} .60 \mathrm{c} ; 1 \mathrm{~b} . \$ 2.25$.

PURPLE TOP STRAP LEAVED. The standard for this part of the country. Superior for early or late planting. Round, flat, good sized, small top with but few leaves; flesh very fine; flavor good. Pkt. 5c; oz. 15c; $1 / 4$ lb. 50c; lb. $\$ 1.50$.

POMERIAN WHITE GLOBE. This is a free-growing, rough leaved sort, useful for both table and stock. It is not quite so rapid growth as the flat varieties: may be expected to come in as a succession in autumn and is admired for table use in early winter. Pkt. 5c; oz. 15c; $1 / 4$ lb. 55c; lb. \$2.00.

LONG WHITE or COW HORN. Without a question a good flavored and delicate sort. A distinct feature is its rapid growth. This variety is a pure white, except a dash of green at the crown, and in shape is long like a carrot and generally crooked, hence its name. Pkt. 5c; oz. 15c; $1 / 4$ lb. 55c; lb. $\$ 2.00$. 


\section{TURNIPS-Continued.}

EARLY WHITE EGG. A quick-growing, eggshaped variety, perfectly smooth, pure white, growing half out of the ground, with small top and rough leaves. Its pure white skin and quick growth make it particularly suitable for market purposes. The flesh is very sweet, firm and mild, never having the rank taste of some varieties. Pkt. $5 \mathrm{c} ;$ oz. $15 \mathrm{c} ; 1 / 4 \mathrm{lb}$. $55 \mathrm{c} ; \mathrm{lb} . \$ 2.00$.

EARLY WHITE FLAT DUTCH. This is a popular early turnip for table use. For autumn and the early winter use this and the purple top are highly popular. Pkt. 5c; oz. 15c; $1 / 4$ lb. 50c; lb. \$1.75.

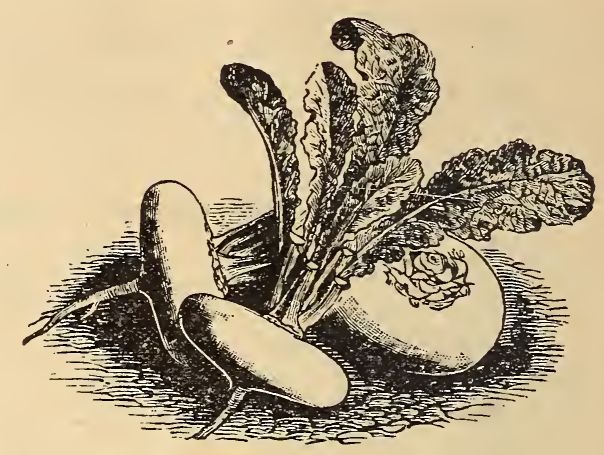

WHITE FLAT DUTCH

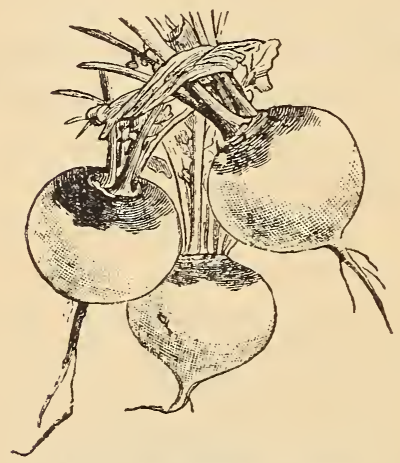

RED TOP WHITE GLOBE

RED TOP WHITE GLOBE. Upper half is of pur plish red color, while the lower half is pure white. Flesh is white throughout, crisp and of excellent table quality. It is rather late, grows to a large size, and may also be profitable used for stock. Pkt. 5c; oz. 15c; $1 / 4$ lb. 50c; lb. $\$ 1.75$

SEVEN TOP. Cultivated exclusively in the South for the, tops which are used for greens. It is very hardy and will grow all winter; but does not produce a good root Pkt. 5c; oz. 15c; $1 / 4$ lb. 50c; lb. \$1.75.

\section{YELLOW FLESHED VARIETIES}

AMBER GLOBE OR STRAP LEAVED. One of the best varieties for table use or for a field crop for stock. Flesh yellow, fine-grained and sweet, color of skin yellow, with green top. Hardy, keeps well, a good cropper, grows to a very large size. Pkt. 5c; oz. 15c; $1 / 4$ lb. 55c; lb. \$2.00.

YELLOW ABERDEEN or SCOTCH YELLOW. This is a turnip fine for cattle feeding. It attains a large size, is solid, nutritious, a good keeper, and can be recommended in every respect Pkt. 5c; oz. 15c; $1 / 4$ lb. 55c; lb. $\$ 2.00$.

\section{RUTABAGAS or SWEDISH TURNIPS}

PURPLE TOP YELLOW RUTABAGA. The best variety of Swedish turnip in cultivation. Hardy and productive, flesh yellow, of solid texture, sweet and well flavored; shape slightly oblong; terminates abruptly with no side or bottom roots: color deep purple above and bright yellow under the ground; leaves small, light green with little or no neck; the most perfect in form, the richest in flavor and the best in every respect. Pkt. 5c; oz. 15c; 1/4 lb. 60c; lb. \$2.00.

SWEET GERMAN. Flesh white, hard and firm, partaking much of the nature of the rutabaga. Must be sown much earlier than the flat turnip. In the Autumn and the early Winter it is apt to be too hard, but mellows like an apple by keeping. Pkt. 5c; oz. 15c; $1 / 4$ lb. 60c; lb. \$2.25. 


\section{AROMATIC, MEDICINAL AND POT HERBS}

ANISE. An annual, cultivated for its seeds and its leaves, which have a fragrant. agreeable scent and a pleasant taste. Pkt. 5c; oz. 15c.

BALM. A hardy perennial of aromatic taste and a fragrant smell. Pkt. 5c; oz. 25c.

BORAGE-GURKENKRAUT. Annual. In Germany the leaves are cut and used for a cucumber salad. Beautiful blue flowers. Pkt. 5c; oz. 15 c.

CARAWAY-KUEMMEL. The seeds are used for flavoring. Pkt. 5c; oz. 10c.

CATNIP or CATMINT. A great favorite among medicinal herbs. Pkt. 5c; oz. 30c.

CHERFIL. Annual, used for soups and salads. Pkt. 5c; oz. 25c.

CORIANDER. Annual, its tender leaves are sometimes used for soups and salads. Pkt. 5c; oz. 10c.

DANDELION-LOEWENZAHN. Perennial. Cultivated for Spring greens; an excellent tonic. Pkt. 5c; oz. 25c.

DILL. Annual. It is cultivated for its seeds which are used medicinally and for flavoring pirkles. Pkt. 5c; oz. 20c.

HOREHOUND. Perennial. Of strong and aromatic smell; used as a tonic. Pkt. 5c;oz. 20c.

HYSSOP. A perennial with aromatic flowers and of pungent flavor. Pkt. 5c; oz. $20 \mathrm{c}$.

LAVENDER. Perennial. Cultivated for its fragrant flowers and aromatic leaves. Pkt. 5c oz. 25c.
ROSEMARY. Perennial. The tops only are used as a medicine. Pkt. 5c; oz. 40c.

RUE. Perennial. A very powerful tonic. It must not be allowed to run to seed. Pkt. 5 c; oz. 25c.

SAGE. Perennial. Tea made from these leaves is an exdellent means oi producing sweat. Pkt. 5c; oz. 40c.

SAFFRON. Annual. The dried flowers are used for medicinal purposes. Pkt. 5c; oz. 20 c.

SAVORY. Annual. Leaves are used for culinary purposes Pkt. 5c; oz. 20c.

SORREL. Broad leaved. Perennial. Used in soups and salads and sometimes cooked like spinach. Pkt. 5c; oz. 20c.

SIVEET BASIL. The leaves are used for highly seasoned dishes as well as in soups, stews and sauces. Plit. 5c; oz. 20c.

SWEET FENNEL. Perennial. Tea made from the seed is an excellent remedy in case of colic and stomach complaints. Pkt. 5c; oz. 20c.

SWEET MARJORAM. Biennial. The leaves are used in soups, the seeds in the manufacture of sausage. In aromatic of sweet flavor. Pkt. 5c; oz. 25c.

SWEET THYME. Perenn:al. Thyme tea is an exceilent remedy for nervous headaches. Pkt. 5c; oz. 30c.

IVORMWOOD. Perennial. Used for med. icinal purposes. Beneficial to poultry and should be planted in every poultry yard. Plt. $5 c$; oz. 40c.

\section{NO GARDEN IS COMPLETE WITHOUT A FEW HERBS. VEGETABLE PLANTS}

We will have the following plants in season. The prices per dozen are postage paid. but those in large quantities are express: the purchaser to pay the charges. We will pack all plants, in first class manner and ship only fresh plants, but cannot guarantee safe arrival.

We will have all standard varieties, but at times we may be out of some of these and if the customers will state whether or not we may substitute it will hasten matters.

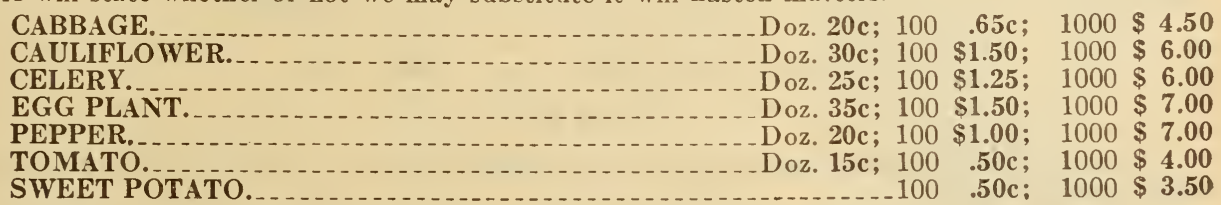

No Plants or other Perishable Stock sent C. O. D.

\section{ROOTS.}

ASPARAGUS. Doz. $25 \mathrm{c} ; 100 \$ 1.00 ; 1000 \$ 6.00$.

RHUBARB. (Linneaus and Victoria.) Postpaid. 2 for $25 \mathrm{c} ; 5$ for 50c; 12 for $\$ 100$. Not postpaid. 85c. per doz; $\$ 5.00$ per 100 .

Anything in the Seed line not mentioned in this Catalog write us or Phone Crockett 189 for information. 


\section{GENERAL LIST OF FLOWER SEEDS}

\section{All Prices of Flower Seeds are Postpaid}

ABRONIA UMBELLETA. A handsome trailing plant with clusters of sweet-scented flowers, resembling verbenas in shape, but of smaller size; color rose lilac, with white eyes. Fine for baskets and vases as well as the garden. Remove the husks from the seed before sowing as it grows much surer. Height 6 inches. Half hardy annual. Pkt. 5c.

ABUTILON or FLOWERING MAPLE. Desirable plant for the conservatory in winter, and effective border plants during summer, producing a profusion of flowers. Half hardy shrubs. Height 2 to 6 feet; perennial. Finest mixed. Pkt. 15c.

ACROCLINIUM (Everlasting). This beautiful everlasting flower somewhat resembles the Rodanthe, but the flower heads are of a larger size. It is largely used for winter bouquet, for which purpose the flowers should be cut before they are well expanded. Half hardy annual. Mixed, Pkt.5c.

ALDUMINA or ALLEGHENY VINE. A most beautiful and graceful climber, thriving in a sheltered situation, and climbing by its tendrils to any object within reach, Is sometimes known as Mountain Fringe, Wood Fringe, and Allegheny Vine. The beautiful pink and white flowers are produced in abundance during the three summer months. It is biennial and makes but little growth the first season. Height 15 feet. White and Pink. Pkt. 10c.

ADONIS AESTIVALIS. Plants with fine and graceful foliage and brilliant scarlet flowers, remaining in blooın a long time. Grows well in shade or under trees. Height 1 foct. Pkt. 5c.

ALONSOA MYRTIFOLIA. A attractive bedding plant with remarkably brilliant scarlet llowers, in bloom from July till frost. Removed into the house, they bloom well during the winter. Height 18 inches. Half hardy annual Pkt. 5c.

ALYSSUM, SWEET. A favorite flower for bouquets, white, very fragrant and producing a succession of blooms through the summer and until after severe frosts. Always wanted when a bouquet is made. Height 1 foot. Hardy annual.

MARITINUM. Pkt. 5c; oz. 25c

LITTLE GEM. Pkt. 5c; oz. 35c.

AQUILEGIA COERULEA. (True Rocky Mountain Columbine.) Colorado's emblematic flower. Needs to be seen to be appreciated. Color is a light blue, in very high altitudes nearly white. We are headquarters for this seed and furnish the true stock. Pkt. 10c.

OTHER VARIETIES UF AQUILEGIA. These new double sorts are very beautiful and embrace a variety of colors and forms. Height from one to three feet. Hardy perrenial.

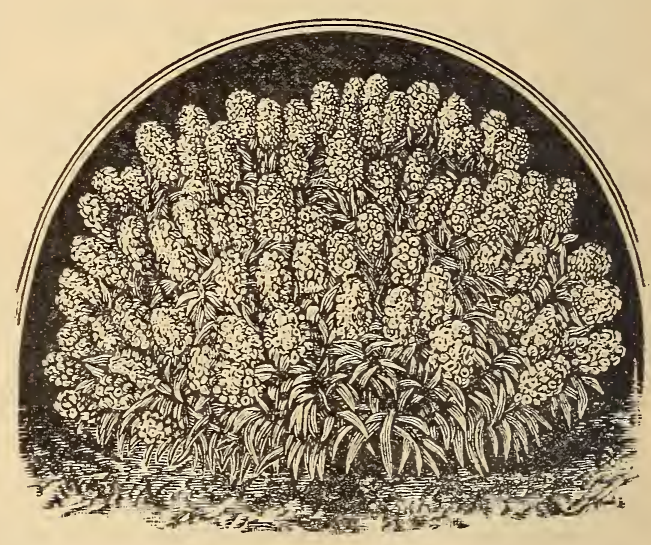

ALYSSUM

\section{Mixed Colors Pkt. 10c. Yellow. Pkt. 10c.}

\section{DO IT NOW}

Putting off ordering seed early ruins thousands of gardens every year. Order now and you will have them sure.

ANTIRRHINUM. (Snapdragon.) One of the most desirable flowers in the catalog for its variety of color and succession of bloom, lasting from July till severe frosts. The plants should be covered with fine boughs or other light material, in November, and they usually survive and bloom finely the second year. Height 1 foot. Biennial.

Dwarf Mixed Colors. Pkt 5c.

Tall, Mixed Colors. Pkt. 5c.

Queen of the North, White. Pkt. 5c.

CORAL. New variety growing $21 / 2$ feet high and a profuse bloomer. Color, bright red and white throat. Pkt. 10c.

AGERATUM MEXICANUM. Flowers light blue or lavender, very desirable for bouquets, furnishing a continuous bloom through the summer. Plants flower well in house all winter, when potted in the fall before frost. Height 12 inches Hardy annual. Pkt. 5c. 
AGROSTEMMA CORONARIA. (Rose Champion.) Perfectly hardy plants, producing pretty pink-like blossoms, on long, slender stems. Very useful for cutting bouquets, and prètty in masses or in bed. About $1 \frac{1}{2}$ feet high. Perrenial. Fine mixed. Pkt. 5c.

AMARANTHUS. Valuable for its varieties of handsome foliage, whether grown in the conservatory or garden. The colors will be more brilliant if planted in moderateiy rich soil. Height 2 3 feet. Hardy annual.

Amaranthus tricolor. (Joseph's coat.) Pkt. 5c.

Amaranthus caudatus. (Love lies bleeding.) Pkt. 5c.

Amaranthus cruentus. (Princess feather.) Pkt. 5c.

AMMOBIUM ALATUM. A small, white Immotrelle, everlasting, very useful for cutting when fresh and drying admirable for a winter bouquet; producing a succession of bloom from July until frost. Height 18 to 24 inches. Hardy annual. Pkt. 5c.

AMPELOPSIS. One of the best climbing plants for permanent situations, as it is perfectly hardy, clinging to the sides of whatever it may be grown against by the rootlets it throws out all along the stems. In the autumn the dark green foliage assumes beautiful tints of orange, crimson, etc. Height 5 to 10 feet. Hardy perrenial.

Ampelopsis Quinquefolia. (American Woodbine.) Pkt. 5c.

Ampelopsis Veitchi. (Japan or Boston Ivy.) Plt. 5c.

ARMERIA MARITIMA. (Sea Pink.) These handsome plants are well adapted for ornamenting rock work and edging walks. Hardy perenn al. Height 6 inches. Pkt. 5c.

ASPERULA AZUREA SETOSA. A flower finely adapted for bouquets by reason of its shape, size and delicate color - a light blue or lavender.

In bloom from July until after severe frosts. Height 9 inches. Hardy annual. Pkt. 5c.

\section{ASTERS}

Our mixed asters are well worthy of the name unrivaled. Our mixture has no rival. It is made up by ourselves of over twenty varieties of the finest asters grown for us by one of the greatest aster specialists in Calfornia.

No such superb collection has ever been offered by any seedsmen before. It contains the German, Boltze's Dwarf Bouquet, Mignon, Queen, Pryamidal Bouquet, Chrysanthemum Flowered, Victoria Crown, Perfection, German Quilled, Comet, Giant Comet, Lady, Queen of the Market, Victoria Needle, Washington, Imbricated Pompon, Jewel, Betteridge's Quilled, Cocardeau, Tall Chrysanthemum, and White Branching, each of them except the last being in assorted colors. Our unrivaled mixture will make a magnificent display. one that should be in every fiower garden in the South. Pkt. 10c

GIANT BRANCHING. Beautiful asters for cut-flowers. Quite different in several respects from any other aster known, The branching habit is accompanied with great vigor of growth and profusion of bloom. The flowers are very large, very double, borne on long, stiff stems, and the colors clear and handsome.

White, Azure Blue, Flesh Pink or Crimson. Each of the above. Pkt. 10c.

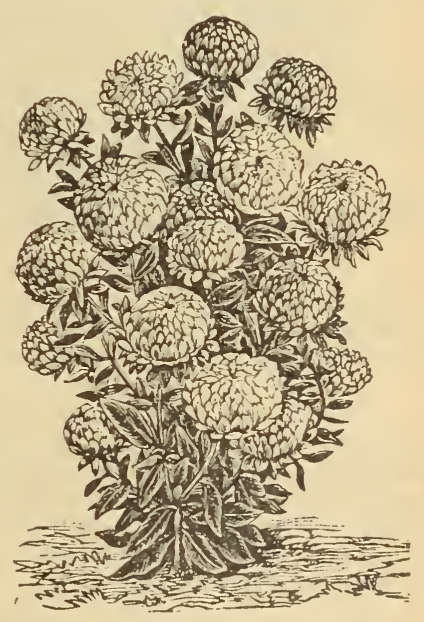

ASTERS

ASPARAGUS. A very popular house plant, much used for hanging baskets. Perennial.

Sprengeri. Pkt. (12 seeds) 15c.

Plumosus Nanus. Pkt. (12 seeds) 15c.

BELL FLOWER. (See Campanula.)

BIGONIA RADICANS. (Trumpet Vine.) Magnificent, hardy, deciduous climber, with brilliant flowers deserving a first place as an ornamental and effective covering for walls of houses, etc. Hardy perennial. Height 20 to 30 feet. Pkt. 10c. 
BEGONIA. (Tuberous rooted.) The newer forms of Begonias are among the best brilliantly beautiful flowering plants. The plants will give an abundance of bloom the first year and at the end of the season they may be dried off by withholding water. Plant the bulbs the following spring. when they will bloom more freely than ever.

Single Mixed. Pkt. 20c.

Double Mixed. Pkt. 25c.

BULBS. (See page 79.)

\section{BACHELOR'S BUTTON. (See Centaurea cyanus.)}

BALSAM. Intense cultivation and continuous selections have improved these flowers to such an extent that persons having the old common forms in mind, will hardly recoznize the new selected sorts. Require a rich, deep soil, good cultivation and plenty of space to grow to perfection.

Double White Alpha Perfecta. Pkt. 10c; oz. 60c.

Double Mixed. Pkt. 5c; oz. 35c. Pkt. 10c.

BALSAM APPLE and PEAR. (Momordica.) Curious rapid climbers. Very ornamental.

If there is any information you want that is not given in this Catalog' write about it. We will give your inquiries prompt and careful attention.

BRACHYCOME IBERIDIFOLIA. (Swan River Daisy.) A delicate dwarf growing plant,

suitable for growing in grasses, edging, and rustic baskets. The flowers are of various shades of blue and white, with dark and white centers, cineraria-like in form, rather bell-shaped. After blooming, the petals of the flower roll up closely. All colros, Mixed. Pkt. 5c.

BOX WOOD. (Evergreen Buxus semperivirens.) A small evergreen with pale green leaves. Can be trained in desired form by shearing, largely used for bordering flower beds. Hardy perennial. Pkt. 10c.

\section{BOSTON IVY. (See Ampleopsis.)}

CALLIOPSIS. A very showy border plant, producing flowers of bright scarlet and orange, crimson, red and brown. If seed pods are removed as fast as they appear the plants will remain in bloom much longer. Height 2 feet. Hardy annual. Mixed colors. Pkt. 10c.

CACALIA COCCINEA. (Tassel Flower.) A pretty annual with flowers of bright scarlet and orange, borne in clusters on slender stalks, about a foot in length. They keep in bloom from early summer until early autumn, furnishing flowers for cutting every day. Height 1 foot. Pkt. 10c.

CALCEOLARIA HYBRIDA GRANDIFLORA. A favorite and universally admired genius, remarkable for their large, beautifully spotted blossoms produced in almost countless variegations of markings. They are grown in pots in the conservatory, greenhouse and garden. Flowers of immense size, seed saved from finest specimens. Pkt. 25c.

CALENDULA OFFICINALIS. This splendid variety has has large flowers, beautifully imbricated resembling in size and from the finest aster. Each petal of plate straw color, is regularly marked with a stripe of bright deep orange. It blooms profusely with a succession of flowers from July until frost. It comes true from seed, and is one of the best annuals for a garden display. Height 18 inches. Pkt. 10c.

\section{CANNA}

Stately plant with foliage of elegan growth, presenting a luxurious and tropical appearance, are much employed in ornamental planting; when planted in clumps of 4 to 5 contrasting colors, they are very effective. Height 3 feet. Tender perennial.

Mixed Colors. Pkt. 10c.

Madam Crozier varieties. Pkt. 10c.

CALIFORNIA POPPY. See Eshsccholtzia.

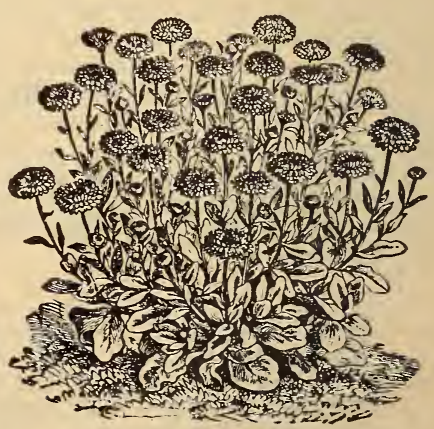


CALLA AETHEOPICA. An old and very desirable plant, either an acquatic or for ornamentation of the drawing room and conservatory. Thrives in any light, rich soil where plentif ully watered Height 1 to 2 feet. Half hardy perennial. Pkt. 10c.

\section{CATCHFLY PLANT. (See Silene.)}

CAMPANUla MEDIUM. (Bell Flower.) Campanulas embrace a great many beautiful popular perennials, like the Canterbury Bell, and also a number of annuals of great value for forming masses, as they are neat of habit, hardy and free bloomers. Height 1 foot. Hardy annyal. Many varieties mixed. Pkt. 10c.

CANDYTUFT. (Iberis coronaria.) All of the colors of the Candytuft are desirable for bouquets, especially the white, for its form and fragrance and prof usion of bloom. Height 1 foot. Hardy annual.

White Rocket. Pkt. 10c.

Many Colors mixed. Pkt. 10c.

\section{CARNATIONS}

This beautiful and well-known flower produces a finer bloom when grown from seed than when grown from cuttings taken from old plants. This seed will produce a fine variety of colors, with flowers good size and substance. Height 18 inches. Half hardy perennial

German. Mixed colors. Ptk. 10c.

Marguerite. Blooms in four months from time of planting. Pkt. 10c.

CASTOR BEANS. (Ricinus.) A luxuriant expansive foliage plant of tropical appearance, that should have a place in every garden affording the necessary space. The stalks of the plant of this variety are brownish red; the leaves are very large, palmate and strikingly elegant. Height 6 to 10 feet. Tender annual. Pkt. 5c.

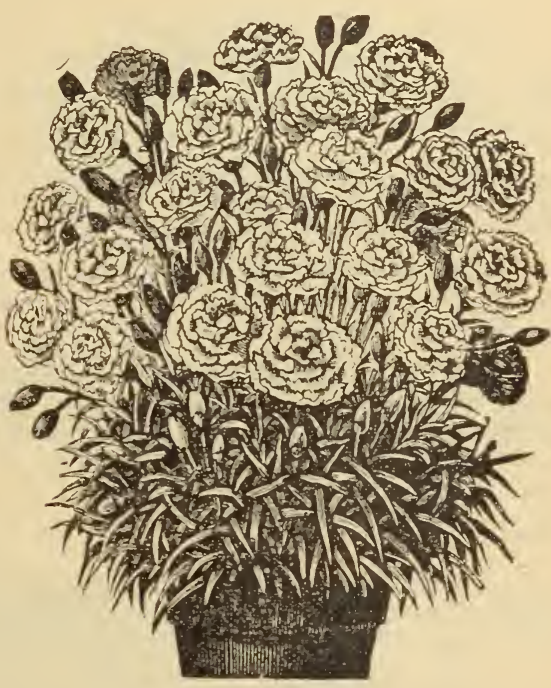

CARNATIONS

CARDINAL CLIMBER. (Impomea Hybrida.) This is easily the best annual climber introduced in recent years. It is a very rapid grower and attains a height of twenty-five feet in a season, It has beautiful fern-like leaves and is literally covered from mid-summer to frost with brilliant. fiery red flowers about one and one-half inches in diameter and borne in clusters of five.

It needs a sunny situation and good rich soil. The seeds should be soaked in water a few hours before sowing and should not be planted outside until about the first of May. This plant is a very shy seeder and therefore the seeds are quite expensive, Pkt. 10c; 3 pkts. 25c.

CENTAUREA MOSCHATA. (Sweet Sultan.) A handsome annual with fragrant flowers borne on long, slender stems. Their fragrance and habit of growth adapt them finely for bouquets. In bloom from July until October. Height 2 feet. Pkt. 10c.

CYANUS. (Bachelor Button.) The "Kornhlume" of the Germans. A showy annual, of easy culture, flowering freely with great variety of color, in a most common garden soil. Height 2 feet. Pkt. 10c.

\section{HUTH SEED COMPANY \\ THE OLDEST AND BEST SEED STORE IN THE SOUTH}




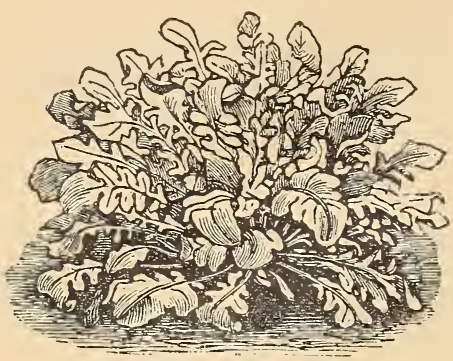

CENTAUREA

CENTAUREA. (Dusty Miller.) Mangificent foliage plants of silver white and gray foliage, indispensible for bor ders and edges. Half hardy perennial. Height 1 foot Pkt. 5c.

MARGUERITE. A sweet-scented Centaurea, about as large as a medium sized Carnation. It is a sport from Centaurea Odorata, and the plants are about 18 inches igh. The flowers are beautifully lacinated and produced on long stems; their lasting quality after being cut is remarkable. The beauty of this easily cultivated annual is certain to excite admiration. Mixed colors. Pkt. 10c;

\section{CHRYSANTHEMUMS}

(Early Annual.)

The glorious and showy autumn blooming Chyrsanthemums, which are now so much admired and cultivated, have their relatives among the summer annuals which are easily raised from seed. The plants can be raised by sowing the seed early in the house or frame and planting them out when the weather is favorable, or the seeds can be sown in an open seed bed, or where the plants are to stand, provided the plants are thinned out to 8 to 12 inches apart. A little shade, or shade in the after part of the day, is desirable for them - a border on the east or northeast side of the house would be desirable. Pinch them back until July 15 to make them grow branching and full. Mixed colors. Pkt. 5c.

CHRYSANTHEMUM MAXIMUM. (Large or Oxeyed Daisy.) A large free blooming hardy perennial, 2 feet high, literally covered with pure white flowers, which are well adapted for cutting, lasting over a week in water. Pkt. 10c.

CHRYSANTHEMUM FRUTESCENS. (Marguerit or Paris Daisy.) This variety, under the name of Marguerite has attained great popularity among florsits. The pretty star shaped white flowers are freely produced and the plant will grow under almost any circumstances. Perennial. Pkt. 10c. postpaid.

CHRYSANTHEMUM PLANTS. Four of each of the best Red, White and Yellow for 75 cents,

PERENNIAL JAPANESE. For late autumn blooming in the house, after the frost has destroyed all the bright colors in the garden, there is no flower to take the place of this finely shaped, double flower produced in profusion. Height 18 inches. Double, mixed colors. Pkt. 15c.

CLEOME or SPIDER PLANT. Bette ${ }^{\boldsymbol{r}}$ known in the IVest as "Rocky Mountain Bee Plant." It is the emblem flower of the Colorado State Bee Keeper's Association. Has a very attractive flower in shades of pick and crimson, on tall branching plants. A splendid honey plant. Pkt. 5c; oz. 10c.

CLEMATIS. Well known and universally admired for climbers, some of the varieties being remarkable for their beauty and the fragrance of their blossoms. Nice covering for arbors, verandas, etc., as they cling readily to almost any object. Most of the kinds are hardy herbaceous perennials, but some little protection in northern latitudes through winter is advisable. Will do well in any garden soil Height 15 feet. A fine mixture of varieties. Pkt. 10c.

CINERARIA HYBRIDA GRANDIFLORA. Very attractive, much admired green house plant. Height 1 to 2 feet. Pkt. 25c.

CINERARIA. (Maritima Candidissima.) White-leaved; used for bedding vases, etc. Height 1 foot. Pkt. 5c.

CLARKIA PUCHELLA. The Clarkia is highly esteemed in Europe, especially in England, where it is as common as the Candytuft. The flowers are very pretty and of many colors, double and single. As the plant is apt to suffer in our hot dry summers, it is better to sow the seed in September and the plants will be large enough by spring to make a good bloom. Hardy annual. Height $11 / 4$ inches. Pkt. 5c.

COBEA SCANDENS. A splendid climbing plant, with large purple bell-shaped flowers and elegant tendrils; when well established grows very rapidly, with numerous branches. Height 15 to 20 feet. Tender annual. Pkt. 10c. 
COSMOS. These are unquestionably very handsome flowers, and it is astonishing how very quickly they have become general favorites. Seeds sown in the open ground in the beginning of May will produce blooming plants in August, and then will continue to flower late in the fall. We offer the following colors: White, Pink, Crimson, Yellow and all colors mixed. Each, Pkt. 5c.

CLIMBING ANNUALS MIXED. In this we have included all the popular, quick-growing climbing annuals, such as Ipomoeas, Nastrutiums, Sweet Peas, Japanese Hops, Cypress Vine, etc. Just the thing for covering old fences, arbors, etc. Pkt. 10c; oz. 25c.

COLEUS. Probably there is no other kind of foliage plants so well known and universally admired as the Coleus. It is one of the most beautiful of our variegated perennial foliage plants for the green house or garden decorations, ribbon-beds, etc., of rapid growth and easy culture. Tender perennial. Height 1 to 2 feet. New Hybrid, mixed. Pkt. 25c.

COLUMBINE. (See Aquilegia.)

CONVALLARIA. (See Lily of the Valley.)

CUCUMBER' WILD. (Echinocystis Lobata.) Ornamental climbing cucumbers with curious fruit, remarkable for its luxuriance and rapidity of growth. Height 15 feet. Hardy annual. Pkt. 5c; oz. $15 \mathrm{c} ; 1 / 4$ lb. 40 c.

\section{DWARF COCKSCOMB}

\section{(Celosia cristata.)}

A highly ornamental plant, producing crested heads of flowers, somewhat resembling a cock's comb. There are many colors and shapes, but the scarlet and crimson ones ave the most brilliant and rich. Height 1 to 2 feet.

Dwarf crimson. Pkt. 10c.

Feathered. Pkt. 10c.

Mixed. Pkt. 5c.

CELOSIA THOMPSONIA MAGNIFICA. I mproved feathered Coxcombes, a recent introduction, and a most valuable one Plants are of regular growth and produce spikes of flowers of the most harmonias color. Can be grown in pots as well as in the open. Mixed colors. Pkt. 15c.

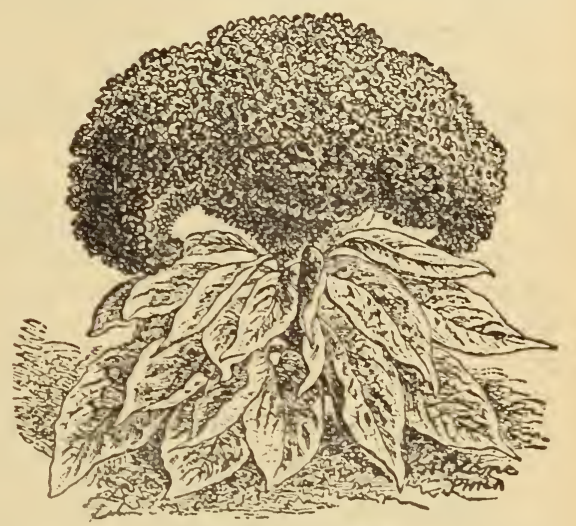

DWARF COXCOMB

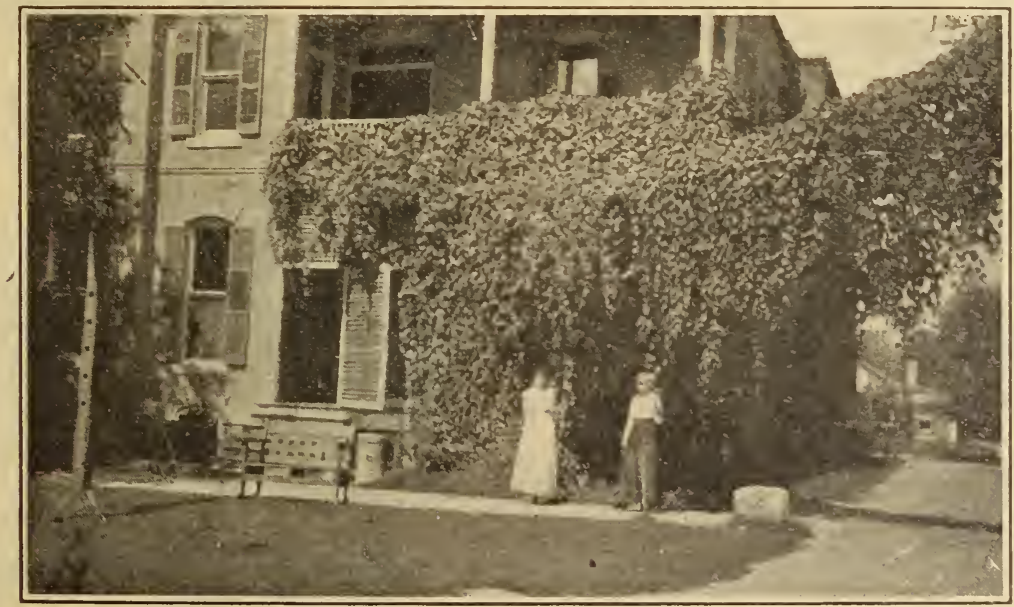

Morning Glory, Ransom Hotel, 316 E. Crockett St., San Antonio, Texas.

BLUE MEXICAN MORNING GLORY. This desirable climber makes a thick, dense growth of great lobed leaves and is brilliant with an endless profusion of immense blue flowers. Pkt. 10c. 
CONCOLULUS MAJOR. (Ipomoea purpurea. Tall morning Glory.) This well known annual is one of the most popular climbers. Of rapid growth, soon covering a fence or trellis with abundant foliage and bright flowers. A great variety of colors and shades. Height 20 feet. Hardy annual. Mixed colors. Pkt. 5c; oz. 25c.

IMPERIAL JAPANESE. The flowers are of immense size and of strong colors. Soak seed before planting. Pkt. 5c; oz. 25c.

FANCY JAPANESE MORNING GLORY. Fringed- The perfection of Morning Glories. Immense flowers, of ten as big as a saucer. The colors, shadings and markings of the flowers are limitless. The foliage is luxuraint, distinct and varied, green, silvery and yellow. The robust vines attain a height of 30 to 40 feet in one season. Soak the seed in luke warm water for a few hours before planting. Mixed colors. Pkt. 10c.

DOUBLE MORNING GLORY. The variety of colors is almost limitless, running from the darkest reds and purples through all shades of blue and pink to snow-white. Flowers are streaked, mottled, striped, marbled and bordered in wonderf ul fashion. They are double and semi-double and some are so much fringed as to have the appearance of a double flower. Mixed colors. Pkt. 10c;

COREOPSIS LANCEOLATA. Flowers large, single golden yellow. For generosity of bloom there is nothing to compare with it, and it will bear cutting far better than any other plant; at the same time it is always graceful. It can be sown freely from seed and does well when treated as an annual. Pkt. 10c.

CORN FLOWER ASTER. (See Stokesis.)

CYPRESS VINE. (Ipomocea Quamoclit.) One of the most beautiful climbers; fine, delicate cut foliage, dotted with small scarlet flowers. For covering pillars, trellis work etc., it is unsurpassed in grace and beauty. Height 12 feet. Tender annual. Mixed colors. Pkt. 5c.

\section{CYCLAMEN}

Well known and universally admired, tuberous rooted plants producing exceedingly handsom e red and white flowers A tender perennial. One foot high.

Persicum. Mxed, of great beauty and many colors. Pkt. 15c.

Gigantem. Mixed, characterized by beautiful foliage and profuse bloom; each flower is from two to two and one-half inches long. Very choice. Pkt. 20c.

Cyclamen Bulbs are ready in October.

Ask for Bulb Catalog.

\section{DAHLIAS}

Dahlias are easy of cultivation; growing freely in most any kind of soil form seed in the spring. Height 4 to 5 feet. Half hardy. Perennial.

Dahlia. Finest Double, mixed. Pkt 10c Dahlia. Finest Single Mixed. Pkt, 10c. For Dahlia Bulbs see page 79.

DAHLIA. Hornsveld's Giant Hybrids' Mixed. This new variety will be found one of our best cut flowers for summer use. - It has magnificent long stemmed, single and semi-double flowers, of immense size and in a great variety of colors. It will bloom freely the first year from seed, but for best results, should be started in a box in the house in February and set outdoors when weather is warm. Pkt. 10c.

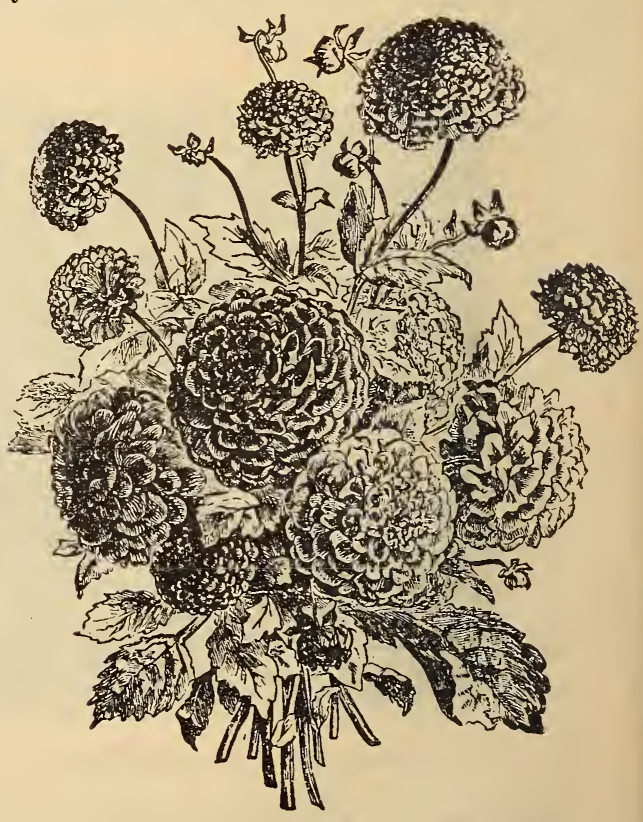

EA HLIA 


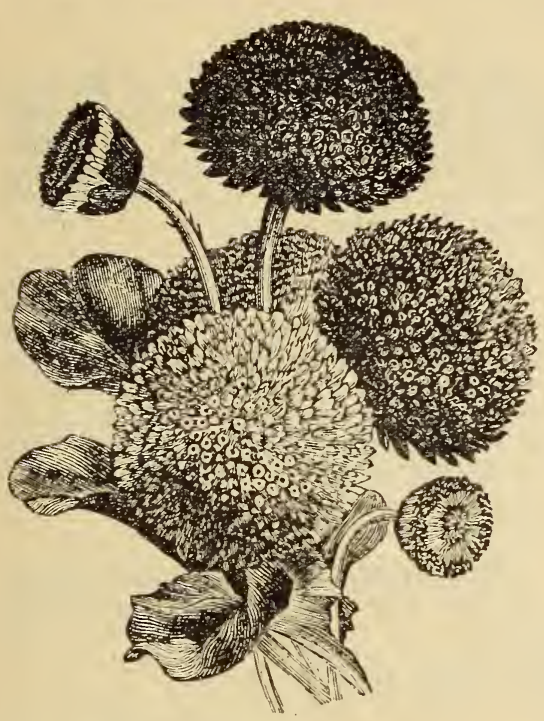

Daisy.

DOUBLE DAISY. (Bellis perennis.) Charming little plants for edging and borders. The flowers are quilled and flat petaled, white, red, pink and variegated. Not all will come double from the seed, and the single ones should be pulled out. Height 6 inches. Tender perennial.

Longfellow, pink; Snowball, white; Double, mixed; each, pkt. 10c.

SHASTA DAISIES. A wonderful evolution over the original form of the wild Daisy, brought about by the constant selection done by Luther Burbank.

Alaska, pure white; California, pale yellow; Westralia, cream yellow; each, pkt. 15c. imum.

OXEYED DAISY. See Chrysanthemum Max-

PARIS DAISY. See Chrysanthemum Fruitescens.

DELPHINUM HYBRIDUM. (Perennial Larkspur.) A very attractive, hardy plant for corners of a yard, also center of flower beds. We furnish seeds of assorted colors. Pkt. 10c.

DELPHINUM AJACIS. (Annual Larkspur.)

A fine variety of colors-shades of blue, red and others striped and mottled. The flowers are produced in spikes, which are continuslly pushing out from the main stem and branches, furnishing abundance of bloom through the season. Height 2 feet.

Double Tall, mixed. Pkt. 5c.

Double Dwarf, mixed. Pkt. 5c.

DIANTHUS BARBATUS. (Sweet Williams.)

The improved varieties of this popular flower are very beautiful, and should find a place in every garden. A great variety of rich flowers, eyed and variegated with other shades forming large trusses of blossoms, remaining a long time in bloom. A bed of Sweet Williams is very attractive the last of June and the first of July, a time when but few other flowers are in bloom. Hardy perennial. Height 18 inches.

Single, mixed. Pkt. 10c.

Double, mixed. Pkt. 10c.

DIGITALIS. (Foxglove.) Showy and useful flowers for the border, flowers borne in tall spikes, bell or thimble shaped of all colors; new plants may be obtained by dividing the roots. Height 2 feet. Hardy perennial. Mixed colors. Pkt. 10c.

DOLICHOS LABLAB. (Hyacinth Bean.) Splendid climbers with abundant clustered spikes of purple and white flowers, which are followed by exceedingly ornamental seed pods. It is of rapid growth and often runs 30 feet in a season. Height 10 to 20 feet. Tender annual. Pkt. 5c.

EVERLASTING FLOWERS. Containing all the popular varieties of the "straw flower" class. All kinds mixed. Pkt. 10c.

ESCHSCHOLTZIA. (California Poppy.) A flower attractive in foliage, bud and blossom. One of the most attractive flowers grown. Plants procumbent, forming dense bushy masses, with a succession of lowers from June until after severe frosts. When grown with $\mathrm{D}$ warf Convolvulvus contrasts finely with the dark blue. Height 1 foot. Hardy annual.

Californica. The original variety. Pkt. 10c.

Early Douglass.; Yellow with golden center. Pkt. 10c.

edge. Pkt. 10c.

Mammoth Golden West. Large flowers of orange color shading to yellow at the

FOUR O’CLOCK. (See Marvel off Peru.)

PLANT ENGLISH RYE GRASS FOR YOUR WINTER LAWN. 


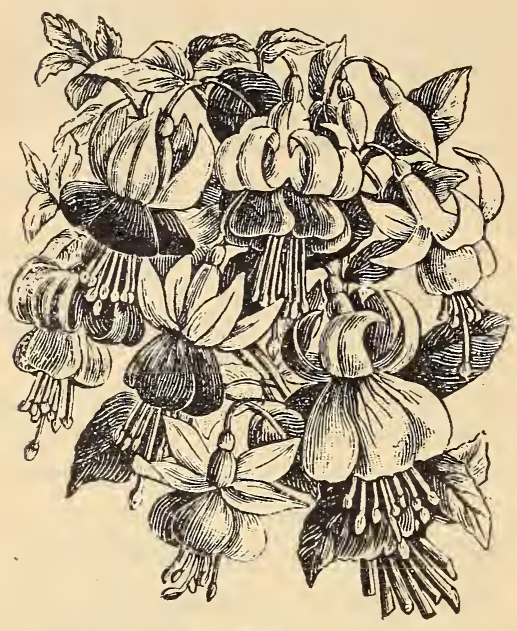

Fuchsia.

FUCHSIA. The varieties of Fuchsias are now numbered by hundreds and some are exceedingly beautiful. They are as easily grown from seeds as raised from cuttings, and from seed many improved varieties are obtained. Height 1 to 3 feet. Double and Single mixed. Pkt. 25c.

FEVERFEW. (Matricaria capensis) A free-flowering, half hardy perennial plant growing 18 inches in height. Seed sown early in the spring in the open ground will produce flowers by fall. The plant throws up numerous stems terminating in clusters of very double pure white flowers three quarters of an inch in diameter. These are desirable for cut flowers. Plants bloom freely when grown in a cool room. Pkt.10c.

\section{FLAX. Scarlet. (See Linum.)}

FORGET-ME-NOT. (Myosotis Alpestris.) This beautiful little flower is too well known to require description or recommendation. The delicate blue flowers appear all summer. Height 6 inches. Hardy perennial. Pkt. 10c.

GILLARDIA. A showy annual, brownish red flowers, bordered with yellow and white, blooming strongly through the season, and until after heavy frosts. Height 18 inches. All colors mixed. Pkt. 10c.

\section{GERANIUM. (Pelargonium zonale)}

Probably the Geranium is better known and more universally admired than any other plant known. The constant succession and durability of bloom till frost comes, the brilliancy of the scarlet and other eolors, and the exquisite markings of the leaves of some of the varieties render them very desirable for pot culture or bedding. No garden seems complete without a bed of them, and in every collection of conservatory or parlor plants we are sure to find the Geranium. Propagation by seed is the only way to obtain new varieties. Height 1 to 2 feet. Half hardy perennial. Single and double mixed. Pkt. 15c.

Each 10c; 3 for $25 c$.

Geranium Plants can be sent by mail.

GILIA. Colors azure and light blue, shaded with yellow and white. Their size, shape and delicate coloring make them useful for bouquets. In bloom from the first of July till after severe frosts have destroyed most of the other annuals. Height 18 inches. Hardy annual. Many colors mixed. Pkt. 10c.

GODETIA. A beautiful class of flowers; the plants are of neat, dwarf compact habit. They produce a profusion of rich carmine flowers, bearing same continually from August until frost. Height 1 foot. Hardy annual. Mixed. Pkt. 10c.

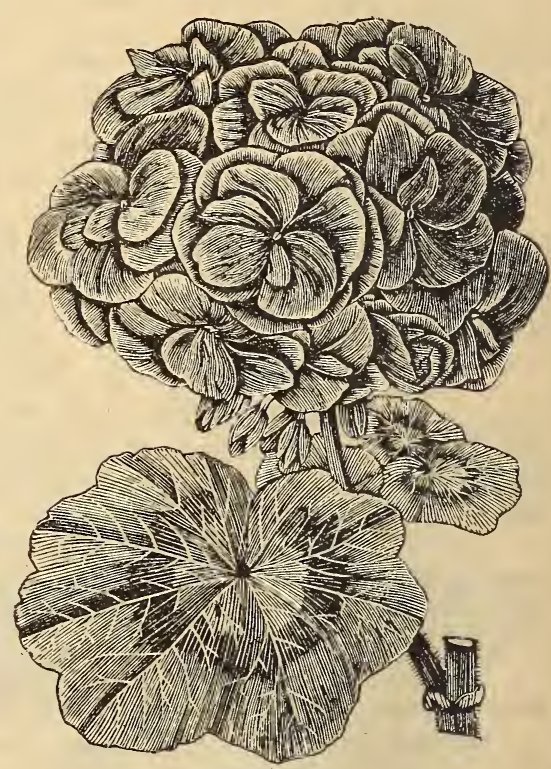

Geranium.

GLOXINIA. Perennial greenhouse plants producing rich and beautifully colored flowers. They deserve extensive cultivation. Hybrids mixed. Pkt. 25c:

Gloxinia bulbs are offered on page 79 .

GOMPHRENA GLOBOSA. (Globe Amaranth.) An excellent everlasting or immortelle; flowers globe-shaped purple, orange and variegated. Retain their shape and color when dried; are also good for cutting as fresh flowers. Height 10 in. Tender annual. Mixed. Pkt. 10c.

GLYCINE SINENSIS. (See Wisteria.) 


\section{GOURDS}

(Useful as well as Ornamental.)

A great variety of curiously formed and marked fruit. The vines are of rapid growth and with luxuriant foliage; adapted for covering screens, arbors, etc. Height 10 to 20 feet. Tender annual. All kinds mixed. Pkt. 5c; $1 / 2$ oz. 15c; oz. 25c.

DISH CLOTH OR LUFFA. A rapid climber having long green fruit, the inside of which is a fibrous mass, which, when shelled and seeds removed, makes an excellent substitute for a bath sponge. Pkt. 10c.

CALABASH PIPE GOURD. A rapid growing climbing annual from South Africa. The very popular Calabash Pipes are made from the fruit. When grown to make pipes it is best to let the vines run on the ground like cucumbers. These pipes are very light and color nicely. Pkt. 10c.

HERCULES CLUB. The longest gourd grown. Pkt. 10c.

DIPPER AND SIPHON. Useful for dipper. Pkt. 10c.

JAPANESE NEST EGG. White like eggs, does not crack and is not injured by heat or cold. Pkt. 10c.

SUGAR TROUGH. With thick tough shell and of great durability. Makes dishes and other utensils for various purposes. Pkt. 10c.

GYPSOPHILA. (Baby's Breath.) Small fragrant flowers, borne on long feathery stems. No flower adds more of light and grace to a bouquet than this, and when once grown will be found indispensable. In bloom through the summer from the first of July until frost. Height 1 foot. Paniculata, pure white, perennial. Pkt. 10. Elegans, delicate pink. Pkt. 10c.

\section{SUNFLOWER}

HELIANTHUS GLOBOSUS. (Sunflower.) An exceedingly double variety of this well known plant, adapted by its stately growth for a background to the lawn or a screen to hide unsightly places. It is also raised as an absorbent of miasma in damp or ill drained situations, thus preventing fevers. The flowers are quite attractive. Hardy annual.

PISTOLOSUS DOUBLE. Globe or Dahlia Sunflowers. Flowers large, double and of rich saffron color. Pkt. 10c.

STELLA. Pure golden yellow with black disks. Pkt. 10c.

ORION. Same as above except petals are twisted like a cactus dahlia. Pkt. 10c;

MAMMOTH RUSSIAN. Pkt. 5c;

RED SUNFLOWER. Horticulturists have been trying for years to get a Red Sunflower. They have not quite succeeded, but have come very near it. We offer a flower.the petals of which are red and tipped with yellow. This is a decided novelty and will please you. Pkt. 10c.

HELICHRYSUM MONSTROSUM. One of the best immortelles; good ishape, size and variety of desirable colors-yellow, sulphur, cream, white, pink, rose, red and crimson. Retain their natural shape very perfectly when dried. In bloom from July until destroyed hy frosts. Height 18 inches. Hardy annual. Many varieties mixed. Pkt. 10c.

HELIOTROPE. A well known popular green house plant, fine for bedding, vases or baskets and exquisite for pot culture in winter. Flowers purple, borne in clusters and exceedingly fragrant. Height 1 foot. Mixed Colors. Pkt. 10c. HIBISCUS AFRICANUS. A showy hardy annual, cream color with rich brown center. Height 2 feet. Pkt. 10c.

\section{HOLLYHOCKS \\ (Anthea Rosea.)}

A great variety of brilliant colors, combining richness and delicacy in a remarkable degree; flowers large and densely double, remaining in bloom for a long time. It is one of the best and most ornamental of the perennials. Height 5 feet. Separate colors, double white, pink maroon, each. Pkt. 10c. Finest prize mixture of double varieties. Pkt. 10c.

HOLLYHOCK ALLEGHENY. This is a species that will bloom the first year if started in the house in March and transplanted in May. The petals are fringed and the flowers of different colors. Pkt. 10c.

HOLLYHOCK ANNUAL. Will bloom in August or beginning of September if sown in April. Flowers are single, semidouble and double. Mixed colors. Pkt. 10c.

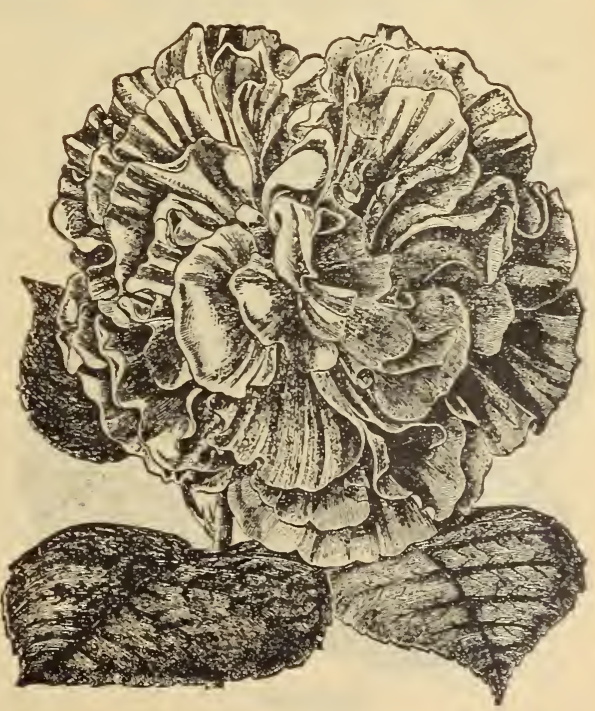

Hibiscus Africanus 
IMPOMOEA QUAMOCLIT. See Cypress Vine.

IPOMOEA MEXICANA. See Moonflower.

INSECT POWDER PLANT. See Pyrethrum.

ICE PLANT. Mesembryabthemum crystallinum.) Dwarf plant of procumbent or trailing habit. finely adapted for vases, rock work, etc. The surface of the foliage is covered with panicles, resembling crystals of ice glistening in the sun, forming a curious and attractive display. Height 6 inches. Tender annual. Pkt. 10c.

JAPANESE HOP. (Humulus japonicus.) A rapid growing, perfectly hardy, annual dimber of the hop family, of the easiest culture and indispensable for covering unsightly objects, or verandas, trellises, etc. Sows itself after the first year. Variegated leaves. Pkt. 10c.

JOB'S TEAR. (Coix Lachrymae.) Curious ornamental grass from East India with corn like leaves and seeds of light slate color, wonderfully lustrous. Valuable for the formation of bouquets, in connection with everlasting flowers and strings of handsome beads are formed from the seeds. Height 3 feet. Hardy annual. Pkt. 10c.

KOCHIA TRICHOPHILA. (Also called Mexican Burning Bush or Summer Cypress.) This we consider one of the most ornamental border or hedge plants that has ever been brought out and it is sure to attract attention. The plants branch freely, and the stems are clothed with slender light green leaves. Early in the fall the ends of the shoots are thickly set with small bright scarlet flowers, the bushy plants resembling balls of fire. The plants are equally showy planted singly to show the round, ball-like forms on all sides or grown in continuous rows. Pkt. 10c.

KUDZU VINE. (Jack-in-the-Bean-Stalk Vine-Pueraria Thumbergiana.) The most rapid growing plant we have ever seen. It dies to the ground each fall, but makes the remarkable growth of from 50 to 70 feet each summer. The leaves resemble those of the lima bean and the foliage is very derıse. Will grow anywhere and can stand an immense amount of hot weather. It grows slowly at first but when once started it will surprise you. You can almost see it grow. Fine for covering porches, arbors or old tress. Pkt. 10c.

LANTANA. Rapid growing plants; the flowers are borne in Verbena-like heads embracing every shade of pink, purple, orange and white. Half hardy perennial. Height 3 feet. Pkt. 10c.

\section{LARKSPUR. (See Delphinum.)}

LINUM GRANDIFLORUM RUBRUM. (Scarlet Flax.) Distinguished for the brilliant colored flowers, which are deep crimson with black centers, saucer shaped, and very conspicuous in bed or border. The foliage of the plant is slender and delicate, and the flowers produce very little seed. Height $1 \frac{1}{2}$ feet. Hardy annual. Pkt. 10c.

LOBELIA. An elegant and useful class of dwarf plants, compact growth, bearing a profusion of delicate flowers. In bloom during summer and autumn. Makes a neat and effective border for geranium beds and beds of ornamental plants; pretty for baskets, vases and piazza decoration. Height 6 inches. Half hardy annual. Blue Crystal Palace. Pkt. 10c.

\section{LOVE IN A MIST. (See Nigella.)}

MARVEL OF PERU. (Mariabilis jalaba or Four O'Clock.) A handsome plant for making an attractive display of its many colored flowers from the middle of July until frost. The blossoms are marbled and spotted in the most diversified manner, the same plant producing

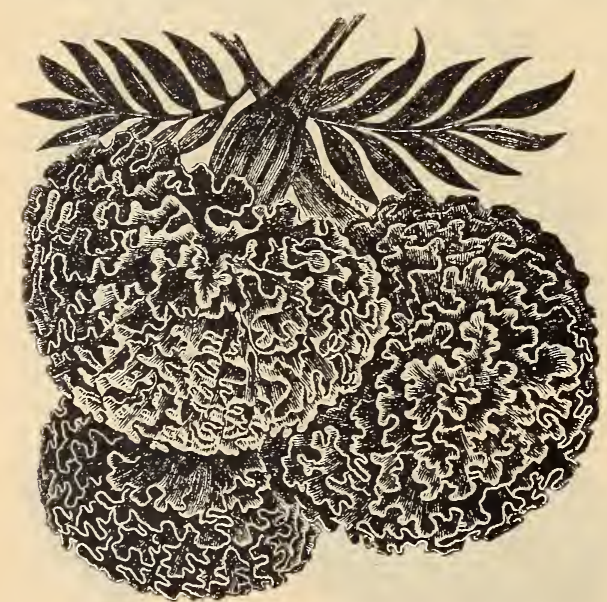

Marigold. different colors; some branches will grow flowers of a single color only, while others will have striped or partly colored. The leading colors are red, white and yellow, with stripes and variegations of all three. Height 2 feet. Hardy annual. Pkt. 10c;

MAURANDIA. The vine is one of the best for window garden and almost equal to smilax in delicate beauty. It is very hardy, blooms profusely and is very easily grown from seeds and roots, from cuttings. Pkt. 10c.

\section{MARIGOLD (Tagetes patula nana.)}

A showy plant of compact symmetrical growth, handsome foliage and a profusion of flowers of brilliant colors of yellow and finely variegated and striped with dark rich colors of maroon and brown. Flowers of this variety are about 1 inch in diameter, full double to the center and cover the plant profusely. Height 1 foot. Half hardy annual.

Dwarf Double, French. Pkt. 10c.

Dwarf Double, African. (Tagetes erecta nana. Pkt. 10c: 
MESENBRIANTHEMUM. See Ice Plant.

MEXICAN BURNING BUSH. See Kochia.

MORNING GLORY. (See Convolvulus.)

MIGNONETTE. (Reseda odorata.)

GRANDIFLORA. Very fragrant, large flowering.

Pkt. 5c; oz. 15c.

GOLDEN QUEEN. Of golden yellow color. Pkt.

5c; oz. 40c.

GIANT MATCHETT is the popular strain used by florists. Pkt. 5c; oz. 40c.

MIMOSA PUDICA. (Sensitive Plant.) A curious plant manifesting sensations to the touch of any object that jars or stings the leaves or branches, stalks immediately drooping or folding together, as if possessed with life and an over supply of nerves. affording a source of amusement for the little and large folks. Height 1 foot. Tender annual. Pkt. 10c.

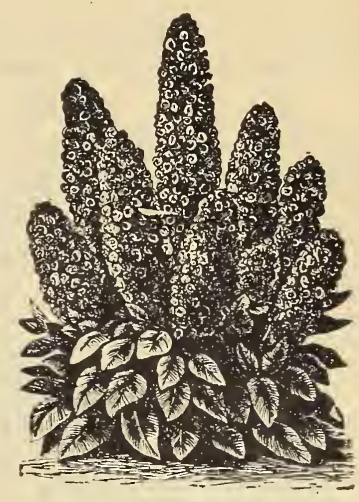

Mignonette.

MIMULUS. These flowers are remarkable for their rich and beautiful markings and spots; well adapted for vases, pots and baskets, and also open culture in the garden. Height 1 foot. Hardy perennial. Moschatus. Musk plant. Pkt. 10c. Tigrinus. Monkey flower. Pkt. 10c.

MOONFLOWER. (Ipomoea Mexicana.) The true Moonflower is one of the most vigerous of all the summer climbers; a single plant can be made to cover, by August 15, a trellis 20 to 30 feet high and 6 feet broad, with a dense mass of leaves studded every night or cloudy day with hundreds of beautiful white wax-like flowers 4 to 6 inches in diameter. Height 30 to 50 feet. Tender annual. Pkt. 10c.

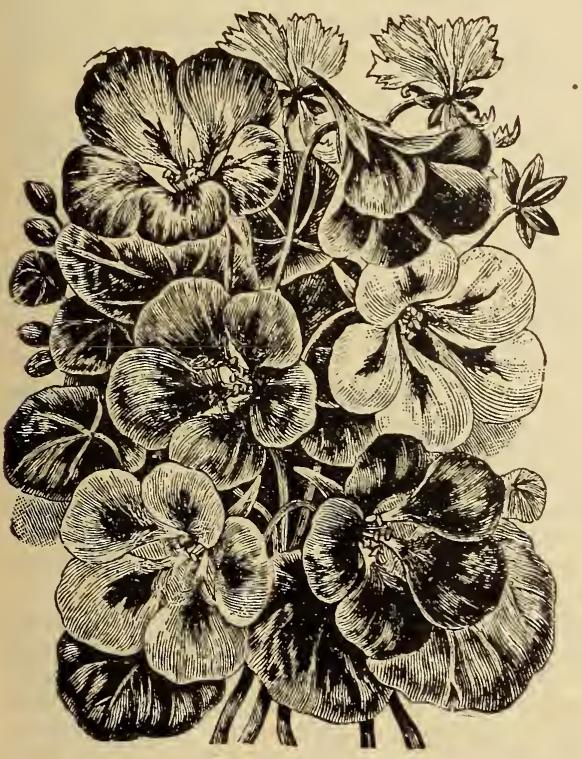

Nasturtium.

MOSS ROSE. (SeePortulaca.)

MOURNING BRIDE. (See Scabiosa.)

HYOSOTIS. (See Forget-Me-Not.)

\section{NASTURTIUM}

TALL VARIEITES. (Tropaeolum majus.) This well known annual is the best for trellis and arbor decoration; flowers of a great variety of rich colors striped and spotted with different shades. Is excellent for vases and baskets; also does finely when grown in beds without trellis support; produces an abundance of flowers from the first of July until frost. Height 6 to 10 feet. Mixed, all colors. Pkt. 5c; oz. 15c.

NEW FRENCH CHAMELEON. This new Nasturtium is a most remarkable advance in this brilliant family. We find that in richness and variety of color it surpasses any other strain, and is also unique in bearing flowers of quite distinct coloring on one and the same plant-some clear, deep crimson, others blotched on light ground and others beautifully mottled. This characteristic as well as wonderful richness of the unusual markings has been fixed in both the tall and dwarf forms. Pkt. 5c; $1 / 2$ oz. 15c; oz. 25c.

NEW IVY LEAVED. This is the most brilliant and showy variety, differing from all other Nasturtiums in both foliage and flower. The plants are of a strong running growth; leaves are deep, rich green, veined with silvery white, closely resembling in form and veining these of the hardy English Ivy. The flowers are of the deepest and richest glowing scarlet, comparatively small in size, but of most distinct form. It is also desirable as a training vine for planting in hanging baskets, vases, or for winter pot culture in the house. All colors mixed. Pkt. 5c; $1 / 2$ oz. $10 \mathrm{c} ;$ oz. $15 \mathrm{c} ; 2$ oz. $25 \mathrm{c}$.

LOBB'S VARIETIES. (Tropaeolum Lobblanum.) - These constitute without doubt some of the finest of our annual climbers; they are as easily grown as the common Tall Nasturtiums which they far surpass in remarkable brilliancy of their flowers, and also in the height of vines and rapidity of growth. Many colors mixed. Pkt. 5c; $1 / 2$ oz. 10c; oz. 15c. 


\section{NASTURTIUMS-(Continued)}

MADAM GUNTER'S HYBRIDS. A grand strain ${ }^{-}$of tall growth, containing many colors not found in any other mixture. Many colors mixed. Pkt. 5c; $1 / 2$ oz. 10c; oz. 15c; 2 oz. 25c.

DWARF VARIETIES. (Tropaeolum majus nanam.)

Dwarf Nasturtiums are very desirable for borders along walks, paths, etc. They are in constant bloom. Grow about a foot high. Mixed. All colors. Pkt. 5c; oz. 15c.

DWARF FRENCH CHAMELEON. Same as described above amongst the tall varieties, but of true dwarf habit. Pkt. 5c; $1 / 2$ oz. 15c; oz. 25c.

NEMOPHILA. This popular plant is to be found in almost every garden, and has secured a place in the heart of every lover of flowers. Of dwarf, spreading habit, is well adapted to border or pot culture. The flowers are exquisitely colored, blotched and spotted; they are quite apt to sport an endless variety of shades from black and blue to lighter colors. Height 6 inches. Hardy annual. Mixed colors. Pkt. 10c.

NICOTIANA AFFINIS. A handsome genius of garden plants of the tobacco family. which are noted for freedom and fragrance of their bloom. Half hardy annual, 3 feet high. The flowers are white, silver, shaped, and have long tubular corollas. Deserve a place in every garden. Pkt. 10c.

NICOTIANA SANDERAE. Introduced a few years ago by one of the leading horticultural firms of England, this remarkable novelty has in an incredibly short time won the admiration of the public, both in America and Europe. The shape of the flower resembles that of the Nicotina Affinis, but the flower tube is short and stout. The greatest beauty of it all is the brilliancy of its carmine-red flowers which are produced in the greatest profusion from early May till the close of autumn. The fragrance is not os pronounced as that of the Nicotiana Affinis but is deliciously sweet. Plant early in spring, same as other hardy plants, and transplant to open ground 2 feet apart when weather is suitable. Pkt. 15c.

NIGELLA DAMASCENA. (Love in a Mist.) A showy annual with finely cut foliage and curiously formed flowers of light blue color. The form and color make them very desirable for bouquets. Height 1 foot. Mixed Colors. Pkt. 10c.

OXALIS. Very attractive and beautiful plants, with richly colored flowers, suitable for rock and rustic baskets. Half hardy perennial. Height 6 inches. Mixed varieties. Pkt. 10c.

Oxalis Bulbs are ready in September. Ask for our Bulb Catalog.

ORNAMENTAL GRASSES. Ornamental grasses are very useful for cutting, when fresh, for summer bouquets, and also dry well for working with everlasting flowers for winter bouquets. This assortment includes the most delicate and graceful varieties.

Pkt. 5c.

Gynerium argenteum (Pampa Grass), forms elegant plumes of striking appearance.

Lagu us ovatus (Hare's Tail), very pretty in bouquets. Pkt. 10c.

*Stipa pennata (Feather Grass). Pkt. 10c.

Many splendid varieties mixed. Pkt. 10c.

Those varieties which are marked with asterisks $\left({ }^{*}\right)$ are perennial.

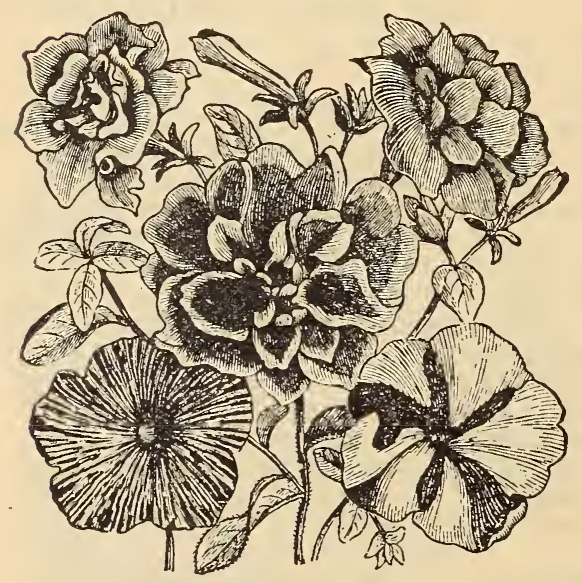

Petunias.

PASSIFLORA COERULEA. (Passion Flower.) A most interesting and well known order of climbers, bearing singularly beautiful flowers. They are the pride of South America and the West Indies, where the woods are filled with their species, climbing from tree to tree, bearing flowers of striking beauty. Pkt. 10c.

\section{PETUNIAS}

One of the best flowers for a splendid display throughout the season. Beautiful new colors striped and marked in the most diversified manner. The ease and culture, profuse and continuous bloom, adaptation for different ways of growing-indoors and in the garden -render the Petunia one of the most valuable of the annuals and entitle it to a generous share of the space in every garden. In bloom from July to October.

GIANTS OF CALIFORNIA. Produce immense large blossoms. Pkt. 15c.

Striped and blotched, single, mixed.

Double mixed, saved from the choicest Pkt. 5e. double flowers only. Pkt. 30c. 


\section{PANSIES}

(Vicis tricolor maxima.)

With the exception of the Rose there is no plant which enjoys such universal popularity as does the Pansy. It has a larger range of color than most plants and is a favorite with all. It is a hardy biennial, blooming continuously from spring until fall and if slightly covered will blossom the second year. It is better, however, to renew each year as the flowers the second year are never as fine as the first year. It is very easy to cultivate and no garden, however small, should be without a Pansy bed.

GIANT PRIZE PANSIES. The imposing five-spotted flowers are from $2 \frac{1}{2}$ to 3 inches in diameter, perfectly round in form and borne on long graceful stems, a decided advantage over the old short stemmed sorts. The plants are of compact form, building perfectly round bushes, with strikingly pretty foliage. The beauty of these plants is in their being covered over with flowers of brilliant and rich colors, cannot be surpassed by any other dwarf growing annual. Pkt. 15c.

CASSIER'S NEW GIANT ODIER. Extra large flowers of the showy and popular Odier type, being all three or five spotted on back grounds of rich glowing colors in many distinct shades. Pkt. 15c.

BUGNOT'S VERY LARGE STRAIN MIXED. An extra large five blotched race; plants vigorous, with short stalks, bearing well above the foliage, immense flowers of fine form and substances. Extra fine. Pkt. 15c.

GERMAN IMPERIAL MIXTURE. While the giant flowered are great favorites, they do not carry all shades and colors which are found in our German mixtures. This is the florists' popular strain. Mixed. A fine assortment. Pkt. 10c; 3 pkts. 25c; $1 / 2$ oz. $75 \mathrm{c}$.

Good Mixed. Consisting of many popular colors of ordinary strains. Pl. 5c; oz. 75c.

TRIMARDEAU. (Giant Pansies.)

White, with dark centers. Black, King of the Blacks. Yellow, a beautiful clear color. Blue, azure hlus Purple, deep royal purple. Bronze, a fine golden. bronze. Mixed, many colors. Each of the above $10 \mathrm{c}$ per pkt., the whole collection of seven for $\mathbf{5 0}$ cents.

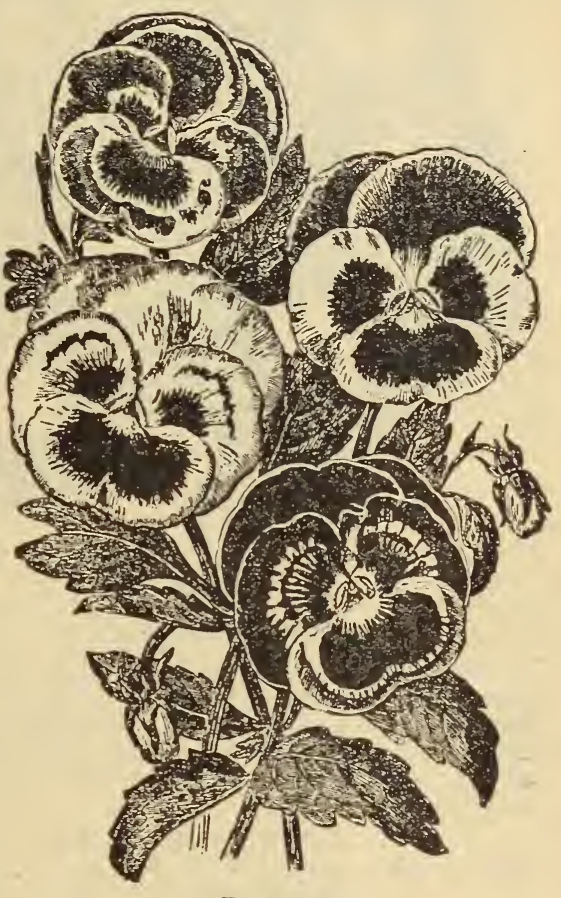

Pansy.

SWEET SCENTED. This lovely new class is the result of a hybridization of the Pansy and the Sweet Violet, retaining the deightful perfume with Pansy bloom 2 inches in diameter, of good substance and in many colors.l They include pure white, yellow, black, maroon, orange and lavender, also striped, blotched, etc. Pkt. 15c.

ORCHID-FLOWERED PANSY. Here is a unique type of pansy among the giant flowered class. The upper petals are upright and plaited resembling orchids. The colors are terra cotta, flesh, orange, rose pink and lilac. The color combinations are unique and different from others. All pansy growers should try a packet of these as we are sure they will he delighted with them. Pkt. 15c.

PASSION FLOWER. (See page 70.)

PETUNIAS. (See page 70.)

\section{SMALL ORDERS-WE LIKE' THEM}

A seed order for 10 cents worth is not too small to be sent to us. All orders large and small, are welcome at Huth's. We are glad to have your order, no matter how small, and the better results you will always get in your garden, always make it worth while to send to Huth's Ior the seed. Please don't think that a 10 to 50 cents order is too small to send to us. We fill tens of thousands of these small orders every year. They are always welcome and receive the same careful treatment and handling that larger ones do. Send your order in now.

See Pages 80 to 82 for Roses, Ferns and Plants. 
PANSY PLANTS. Grown from our Giant Prize Pansy Seed. For many years we have been perfecting our Giant Prize strain of Pansy, and we can confidently recommend it as the finest mixed Pansy in existence. Not only are the flowers large and highly colored, but the varieties are very numerous and the mixture contains all that is best in American and European Pansies to date, the immense number of plants we sell to our private customers sufficiently proves their merit. Strong plants from January to April at 25 cents per doz.

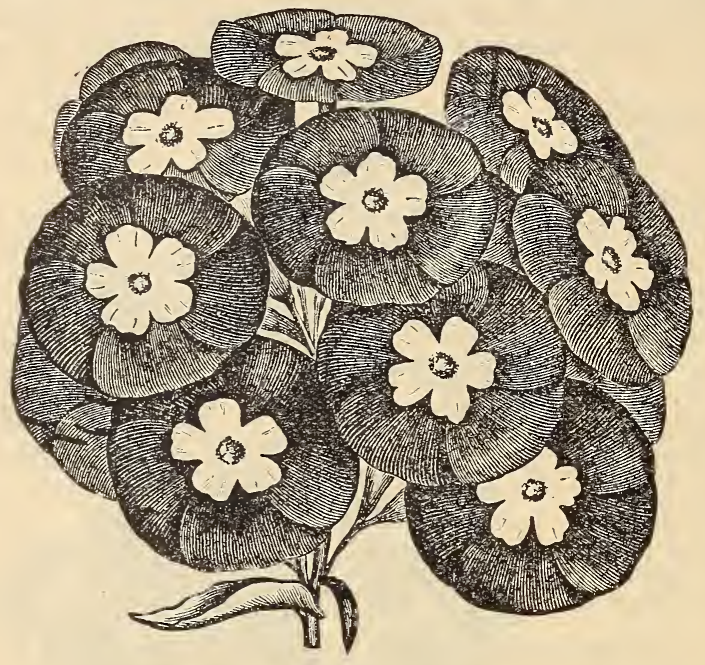

Phlox.

PHLOX DRUMMONDI.

No flower excels this in all the qualities that make it a popular annual. The flowers are brilliant and of varied colors; it blooms profusely and continuously; is one of the last to succumb to the frosts of late October, and is excellent for bouquets. Taking everything into consideration, it should certainly be placed in the light of the half dozen best flowers for garden decoration. Height 18 inches. Mixed. Pkt.5c; oz.1.25.

PHLOX DRUMMONDI GRANDIFLORA. (Extra large flowering.)

Alba, white. Pkt. 10c; oz. shaped flowers. Pkt. 10c.

Mixed. Pkí. 10c; oz. 1.25.

\section{PHLOX DECUSSATA}

Perennial Phlox. Pkt. 10c.

PHLOX PLANTS. Drummondi mixed from January to March. 25c per dozen.

PINKS. (Dianthus.)

Splendid large flowers of the most brilliant colors and markings; constantly in bloom from July until after severe frosts, the first and also the second year. No flower exceed the genius for a brilliant show of colors through the summer. Height 1 foot.

CHINENSIS (double China), mixed. Pkt. 5c; $1 / 4$ oz. $15 \mathrm{c}$; oz. $75 \mathrm{c}$.

LECINIATUS (double Imperial), mixed. Pkt. 5c; oz. 75c.

IMPERIALIS (double fringed, mixed. Pkt. 5c; $1 / 4$ oz. 25c; oz. $75 \mathrm{c}$.

pkt. 5c. Oz. 75c;

HEDDEWIGII (single), mixed.

HEDDEWIGII (double Hedde-

wigii), mixed. Pkt. 5c; oz. $\$ 1.00$.

white. Pkt. 5c.

ALBUS FLORE PLENO (double

DIANTHUS PLUMARIUS (perpetual), June Pink, Clove or Grass Pink, hardy and fine for old-fashioned gardens. Pkt. 5c.

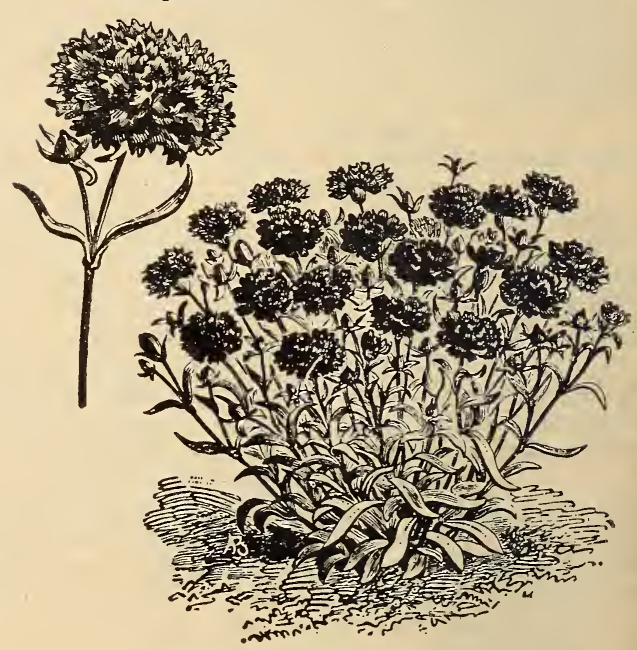

Hardy Garden Pinks

POPPY. (Papaver.) A well known flower of great profusion. Single and double mixed, a grand collection of annual varieties. Pkt. 5c.

FAIRY POPPIES. The flowers are perfectly double, of large size and magnificent form. In colors the grand large flowers are pure white, glowing scarlet, light lilac, scarlet with white and black, rose and deep maroon. Double mixed. Pkt. 5c.

THE SHIRLEY POPPIES. (Papaver Rhaeas.) They are similar in every way to the wild scarlet Field Poppy of England and the continent, but the range of colors is so varied that scarcely two will be found alike. Pkt. 5c. 
ORIENTAL HYBRID POPPIES. (Papaver Orientale.) For brilliancy of coloring there is nothing to equal these Oriental Poppies. The flowers are of enormous size, of ten measuring over six inches in diameter, while the colors range from soft flesh and rose to the most brilliant, dazzling scarlet, and richest maroon purple. Their culture is simple as that of the common garden poppy. One of their most valuable properties is that they are perfectly hardy perennials, increasing in size and beauty from year to year. Pkt. 10c.

POPPY EMPRESS OF INDIA. This beautiful new Poppy produces large single Howers of glistening white with a small band of scarlet around the top. Pkt. 10c.

ICELAND POPPIES. (Papaver Nudicaule.) The delicate, fragrant flowers are exceedingly beautiful, and with their long stems are suitable for cutting. The plants are perfectly hardy, easily cultivated, and the lovely flowers are in bloom from early summer until fall. Hardy perennial, blooming the first year from seed. Pkg. 10c.

PORTULACA GRANDIFLORA. (Moss Rose.) There are scarcely any flowers in cultivation that make such a dazzling display of beauty as a bed of many-hued, brilliant-colored Portulacas. They are in full bloom from about the first of July till killed by frost in the autumn. Plant in open ground after it has become warm in light soil and in a dry situation. After the plant appears withhold water, and if the plants have full exposure to the sun the ground will be covered with the plants and the effect will be beautiful. Tender annual. Height 9 inches.

Double Rose. Mixed. Pkt. 10c.

Single. All colors mixed. Pkt. 10c.

PRIMROSE. (Frimula.) These are perhaps the most desirable of all house plants. They are in almost constant bloom all winter, and if the plants be transferred to the border they will bloom nearly all summer. Though perennial, few plants flower more continually and seed should be sown every year. Give them a long time for growth before flowering, and do not force the young plants, but simply protect them from frost and damp and cutting winds. Height 9 inches.

Obconica. Pkt. 10c.

Sinensis, mixed. Pkt. 20c.

PYRETHRUM. (Insect Powder Plant.) Practical entomologists have long been looking for some effective, safe and cheap insecticide, and now tell us they have found it in the Persian insect powder. This is the dried and powdered flowers of the Pyrethrum Roseum, and it is certain death to plant lice, fiies, cabbage worms and nearly every form of insect life. It is harmless to man, but when diluted with ten times its bulk of flour kills every cabbage worm or other insect it touches. Height 1 foot.

Pyrethrum Roseum. Pkt. 10c.

Pyrethrum Aureum. This is the beautiful bedding plant with golden leaves called "Golden Feather." Pkt. 10c.

RAGGED SAILOR. (See Centaurea Cyanus.)

RESEDA ODORATA. (See Mignonette.)

\section{RICINUS. (See Castor Beans.)}

NEW DWARF ROSE. (Rosa Polyantha Multiflora.) Height 20 inches. This variety comes to us from France. The rose commences blooming when about eight inches high; like annuals, they germinate, flower and produce seed within the first vear. Their bloom is continuous throughout the summer, but is naturally more abundant the second season. The flowers are single, semi-double and double in almost equal proportions and present most all the variations found in other roses. A young plant raised from seed sown expands its first flowers in 3 months. Pkt. 15c.

SALPIGLOSSIS. A beautiful annual that deserves to be more widely known; when once grown in the garden, will be one of the first to be chosen for the next year. Flowers of the richest colors, blue, crimson, yellow, purple, scarlet, etc., with texture like rich velvet, each petal beautifully penciled. Splendid for bouquets. Height 2 feet. Mixed colors. Pkt. 10c.

SCABIOSA ATROPURPUREA. (Mourning Bride.) One of the best flowers for bouquets; plants of dwarf habit and compact, the flowers borne upon long, wiry stems. A great variety of colors from white to very dark purple-almost black. In bloom from August till after severe frosts. Height 18 inches. Tender perennial. Mixed colors. Pkt. 10c.

\section{SUMMER FLOWERING BULBS.}

Order a few Gladiolas, Tuberoses or Caladiums and you'll not regret it. Every August we issue a Fall bulb catalog. if you have not been receiving it, write for it next fall and set out a few Hyacinths, Narcissus and Tulips. 


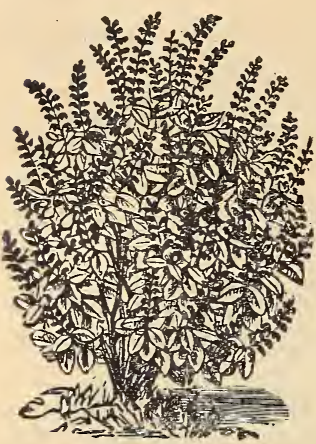

Salvia.

SALVIA SPLENDENS. (Scarlet Sage.)

Flowering Sage, is a very ornamental plant, flowering in spikes and continues in bloom until frost in the open ground, when the plant can be removed to the greenhouse and will continue in bloom a long time. This variety is of the dwarf habit, and the spikes of flowers are not so large as some of the greenhouse sorts. Height $1 \frac{1}{2}$ feet. Tender annual. Pkt. 5c.

\section{SALVIA SPLENDENS PLANTS. 75c per dozen.}

SCHIZANTHUS. This annual should be more widely cultivated. Flowers different shades of blue, curiously cut and delicately spotted, laced with crimson, white and yellow, etc. Adapted for garden and indoor culture. Excellent for bouquets. Height 18 inches. Mixed colors. Pkt 10c.

\section{SENSITIVE PLANT. (See Mimosa Pudica.)}

SILENE ARMERIA. (Catchfly Plant.) A showy, freeflowering plant with bright, dense heads of flowers growing well in common garden soil. Adapted for border, circular beds and ribbons. Height 18 inches. Hardy annual. Pkt. 10c.

SMILAX. (Myrsiphyllum Asparagoides.) No climbing plant in cultivation surpasses this for graceful beauty of its foliage. In cut flowers and for wreaths, etc., it is indispensable to florists. Height 10 inches. Tender annual. Pkt. 10c; oz. 50c.

STOKESIA CYANEA. (Corn Flower Aster.) This is one of the most charming and beautiful native hardy plants. The plant grows from 18 to 20 inches high bearing freely from early July until frost, its handsome lavender-blue Centaurea like blossoms measuring from four to five inches across. We do not hesitate to state that Stokesia is one of the most valuable and derisable hardy plants offered. Pkt. 10c.

\section{SWEET PEAS}

We are headquarters for strictly high grade Sweet Pea Seed. Our growers give special attention to selecting and cleaning. We have orders from all parts of the United States for our selected strains, which are furnished at prices within the reach of all and as low as the ordinary stocks are priced by many.

CULTURE. The Sweet Pea is quite hardy, and may be sown in the Southwest as early as November. To secure a strong growth and the longest season of bloom, the plants should root deeply, and this is aided by planting early and digging the trenches or seed beds five or six inches deep. Farmogerm is the best fertilizer for Sweet Peas. You will find this listed on page 95,96. Sow the seed rather thickly in the trench and cover with two to three inches of soil, hoeing in the balance of the soil when the vines are well started in growth. Thin out the plants to two or three inches apart.

When the young plants are two or three inches in height, they should be furnished with stout brush on which to climb, or stakes may be driven in the rows and twine run from stake to stake to furnish a support for the vines. In wet seasons the earth should be drawn up slightly ridged along the row to drain away the surplus moisture, while in a dry season the surface of the soil should be frequently worked to keep it loose and fine, or else should be well mulched with hay or straw to keep the soil cool and preserve the moisture. Gather the flowers before they fade, as allowing them to produce seed will greatly shorten the season of flowering.

Sweet Peas Up To Date. By Hutchins. A complete treatise on Sweet Pea culture. 10 cents postpaid.

\section{ORCHID-FLOWERED VARIETIES}

Spencer Sweet Peas have extra large flowers that are beautifully waved and crumpled at the eelges of the standard and wings. Be sure and plant at least a few of these varieties. After you have seen these beautiful Spencers you will have no others.

DUPLEX PINK SPENCER. One of the latest. A very large, wavy, cream pink Hower with double or duplex standards.

IRISH BELLE SPENCER. A gorgeous lilac, flushed with pink.

Send Order Now . Don't wait like so many do until too late and then have to plant pays to buy seed early and have them on hand ready for planting time. 


\section{SWEET PEAS-(Continued)}

WHITE SPENCER. Large extremely beautiful whitef lowers. The very best white variety AMERICAN SPENCER. Red striped with white. Very effective.

MRS. ROUTZAHN SPENCER. A beautiful blending of soft straw color, tinted with Bluish pink and shading to apricot.

OTHELLO SPENCER. Deep maroon Flowers very large and the plant a strong grower KING EDWARD SPENCER. Ver large dark flowers of the genuine Spencer type. Very fine.

AURORA SPENCER. Flower a cream white beautifully flaked and mottled with rich orange crimson. 'A vrey pleasing effect.

GLADIS UNWIN. Flowers are large, of bright pink color, with unusually long stems.

PHYLLIS UNWIN. Color of a rich, rosy carmine with crimped and wavy aings.

Prices of any of the above, 10c per pkt., 20c per oz. 60c per $1 / 4 \mathrm{lb}$.

SPECIAL MIXTURE OF SPENC VARIETIES We are offering this excellent mix for the benefit of those who eould like to plant some of these magmificent Spencers, but do not care for separate colors. This mixture is composed of the best and most popular Spencers and will certainly give satisfaction. Pkt. 10c; oz. 20c.

\section{GRANDIFLORA VARIETIES \\ WHITE}

sistent bloomer.

EMILY HENDERSON. A fine per-

pure white variety.

BLANCHE BURPEE. A splen

DOROTHY ECKFORD. One of the best of the whites.

MONT BLANC. Earliest of the white varieties.

\section{YELLOW}

MRS. ECKFORD. Beautifully shaded. A vigorous grower.

\section{PINK AND WHITE}

EARLY BLANCHE FERRY. A beautiful pink and white flower. Very early. PINK brilliant pink.

KATHERINE TRACY. A soft but LOVELY. A delicate shell pink, tinged with yellow; often four flowrrs to the stem

MODESTY. White with a touch of pink at the edges.

\section{ROSE}

HER MAJESTY. Large hooded

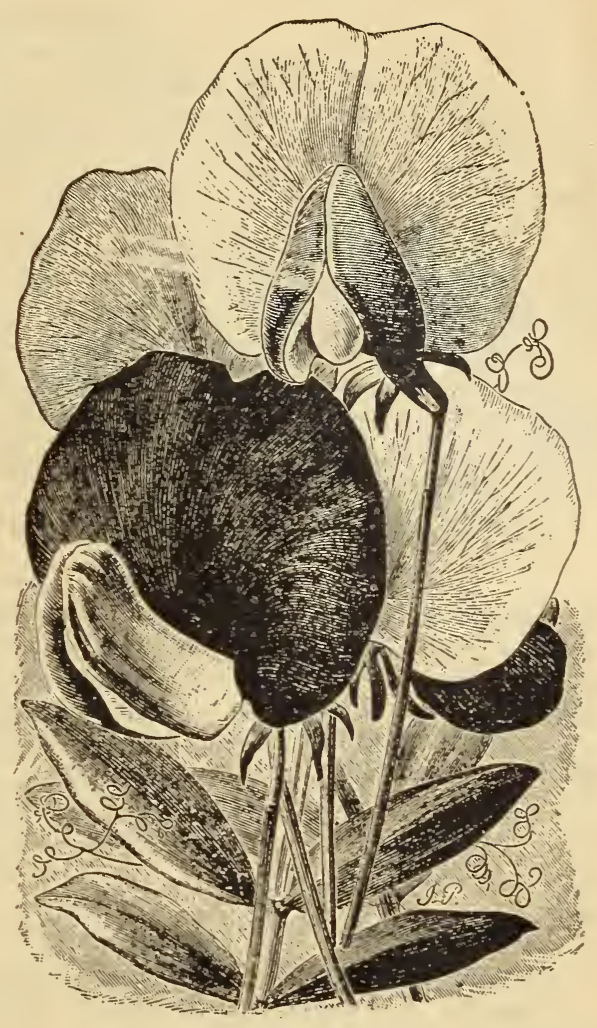

Sweet Peas

SCARLET

KING EDWARD VII. A dark, rich red. Very beautiful.

SALOPIAN. Very bright scarlet with large flowers.

\section{LAVENDER}

LADY GRISEL HAMILTON. One of the very best of the lavenders.

\section{MAROON}

BLACK KNIGHT. Very deep maroon. An improvement on Boreatton and the standard among the marrons.

Bright purple blue.

$$
\text { BLUE }
$$

CAPTAIN OF THE BLUES

NAVY BLUE. The large flowers are of a rich violet purple, giving them the effect of a dark navy blue.

blue.

FLORO NORTON. Bright, clear

\section{VZRIEGATED}

AMERICA. Scarlet stripes on white Very effective.

JUANITA. The standard in mauve and th jwings lavender. Both are steiped.

Prices of any of the above, $5 \mathrm{c}$ per packet 6 packets for $25 \mathrm{c}$; 12 packets for $40 \mathrm{c}$; $15 \mathrm{c}$ per ounce

2 ounce packets $25 \mathrm{c} ; 1 / 4 \mathrm{lb}$. $\$ 1.40$, gstpaid. 


\section{SWEET PEAS-(Continued)}

\section{DOUBLE VARIETIES}

It has been a difficult task to change the habit of the Sweet Pea by hybridization and selection to the double form, and much remains to be done. The result at best is really a semi-double flower. The best varieties we have will not produce more han half the doubles, others remaining of the usual single type. We furnish them mixed. Pkt. 5c; oz. 20c; 2 oz. 30c; $1 / 4$ lb. 50c.

\section{EVERLASTING PEAS.}

A perennial climber producing a succession of white rose and purple blossoms in clusters. Suitable for trellises, arbors, etc. Hardy perennial. Height 5 feet. Mixed colors. Pkt. 5c; oz. 25c.

\section{DWARF VARIETIES}

CUPID SWEET PEAS. A decided acquisition in Sweet Peas. Grows to a height of about 10 inches, suitable for bedding and borders. The blossoms are smaller than those of tall bush varieties.

White Cupid. Pure white blossoms. Pkt. 5c; oz. 20c; 2 oz. 30c: $1 / 4$ lb. 50c.

Pink Cupid. Same as preceding, differing in color only. Pkt. 5c; oz. 20c; 2 oz. $30 \mathrm{c} ; 1 / 4 \mathrm{lb} .50 \mathrm{c}$.

Mixed Cupids. Contains many colors. Prices same as for Pink and White Cupids.

\section{SWEET PEA MIXTURES}

SUNFLOWER MIXTURE. This mixture put up by us is the very best. It is made up of a great many named varieties, selected and mixed by us. This is an extra fancy mixture and should not be classed with the ordinary mixtures on the market. Pkt. 5c; oz. 15c; 2 oz. $25 \mathrm{c} ; 1 / 4$ lb. $40 \mathrm{c}$; lb. 1.40 .

LIGHT COLORS ONLY. From named varieties, mixed to order. Pkt. 5c; oz. $15 \mathrm{c} ; 2$ oz. $25 \mathrm{c} ; 1 / 4 \mathrm{lb} .40 \mathrm{c}$.

SUNFLOWERS. (See Helianthus.)

SWAN RIVER DAISY. (See Brachycome.) chata.)

SWEET SULTAN. (SeeCentaurea Mos-

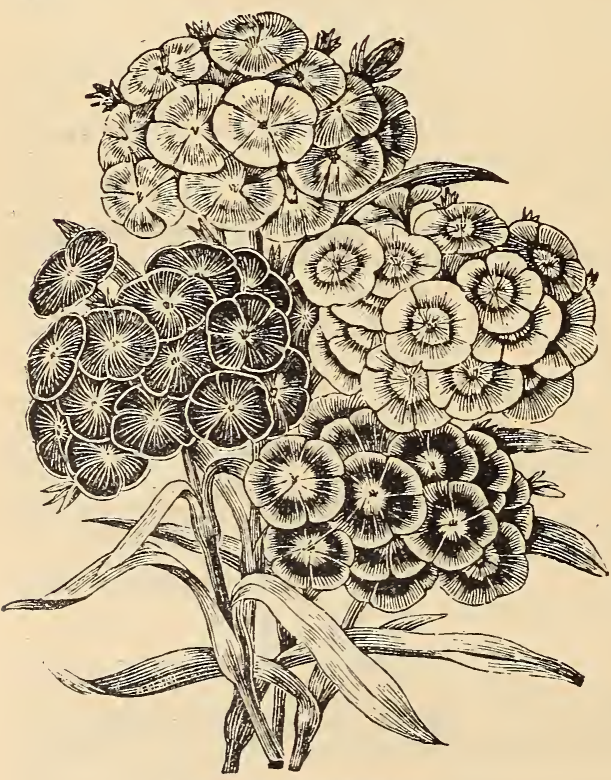

Sweet Williams.

\section{SWEET WILLIAMS}

The improved varieties of this popular flower are very beautiful, and should find a place in every garden. A great variety of rich flowers, eyed and variegated with other shades forming large trusses of blossoms, remaining a long time in bloom. A bed of Sweet Williams is very attractive the last of June and the first of July, a time when but few other flowers are in bloom. Hardy perennial. Height 18 inches.

Single Mixed. Pkt. 10c.

Double Mixed. Pkt. 10c.

\section{TEN WEEKS STOCKS. (Cherianthus Matthiola.)}

Cut and Come Again. Plants grow about one foot high, making a compact bush covered with splendid spikes; in bloom from July till frost. This seed is of our own importation from the most celebrated German growers of these flowers, saved only from the selected pot plants, and will produce the largest proportion possible of large double flowers, in the most brilliant colors and varieties. Half hardy annual. Height 1 foot

Dwarf German Double. Mixed colors. Plat. 10c; $1 / 4$ oz. 75 c.

$60 c$.

Single. Mixed. Pkt. 10c; $1 / 4 \mathrm{oz}$. 
THUNBERGIA ALATUM. (Climbing Blackeyed Susan.) A trailing or climbing plant with flowers of various shades of yellow and white, having a dark center, or eye. Particularly adapted for vases or hanging baskets, for plaza decorations, etc. Height 4 feet. Pkt. 10c.

\section{VERBENA}

The most popular bedding plant grown from seed. The fine varieties of colors with stripes and markings of different shades, profuse and long continued bloom, and excellent for bouquets, making them one of the most desirable annuals in the catalog for general culture. Grown from the seeds, the plants will bloom more profusely than those produced from cuttings.

Mammoth Verbenas. In the following colors: White, pink, purple, blue, scarlet, each. Pkt. 10c.

Mixed Colors. Pkt. 5c.

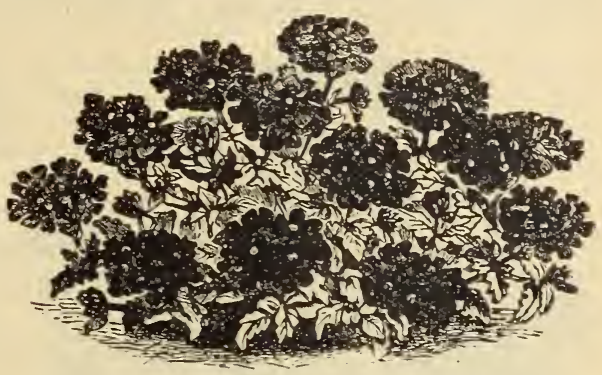

Verbena.

MAMMOTH VERBENA PLANTS. Next to the Geranium the Verbena is the most popular and useful of bedding plants. The collection we offer is as fine a collection as could be found on this continent, containing the most brilliant colors and some right fragrant varieties. In order to keep the plants in the best blooming condition, cut all faded flowers off, and even a severe trimming or clipping tends only to strengthen the plants and keep them in better shape for late flowering. With proper care your Verbenas may be kept in blossom long after other flowers have gone. The demand we had the past season for this popular flower was enormous. Red, white, purple and pink. Price 10 cents each; twelve for 60 cents.

VIOLET. (Viola Odorata.) The violet should not be wanting in any garden on account of its fragrance and early appearance. A single flower will perfume the whole room. Succeeds best in a shady place, and can easily be increased by dividing the roots. The violet is an emblem of faithfulness. Hardy perennial. Height 4 inches. Pkt. 10c.

VIOLET PLANTS. A few plants of this modest but popular favorite should be in every lawn. CALIFORNIA. Single flowers of deepest blue or purple are borne on stems 8 to 12 inches long. Large quantities of this variety are grown for cut-flowers. Splendid for bouquets. dozen 25c.

WILD GARDEN FLOWER. A Mixture of all kinds of Flower Seeds. Anyone who has planted and cultivated flowers in neatly laid out beds and borders is aware of the labor and constant care and attention required to produce the desired effect. To those who cannot give it this care, "The Wild Flower Garden" presents a substitute which for its unusual and varied cheapness, and the small amount of labor necessary for its construction, has no equal. The seeds we offer for the "Wild Flower Garden' are a mixture of over 150 different varieties, and being mixed, can be offered at a much cheaper price than when sold in separate packages. No one not having such a bed can form an idea of its beauty, the different seasons of bloom insuring something new almost every day. Large pkt. $10 \mathrm{c} ; 1 / 4 \mathrm{oz} .15 \mathrm{c} ; 1 / 2 \mathrm{oz} .25 \mathrm{c}$.

VINCA. If seed is sown early the plants will bloom the first summer. They can be taken up in the fall and kept in the house throughout the winter. Mixed colors. Pkt. 5c.

\section{WALL FLOWER. (Cherianthus Cherri.)}

The massive spikes of the Wall Flower are very conspicuous in beds and borders, and are very useful in making bouquets. They are deliciously fragrant, perfectly double and combine many shades of color-the orange, purple and chocolate predominating. Height 18 inches. Tender perennial.

Double, mixed. Pkt. 10c.

Single, mixed. Pkt. 10c.

WHITLAVA GRANDIFLORA. An elegant annual with delicate foliage and a drooping cluster of rich dark blue and white bell-shaped flowers. Is fine for baskets and vases, and for plaza decoration is one of the best, flourishing well in partly shaded situation. Height 1 foot. Pkt. 10c. 
WISTERIA VINE. (Glycine Sinensis.) One of the quickest growing climbers, of fine, bright foliage, producing bunches of rose lilac flowers in great abundance during spring, If once started it will live for years,. Hardy perennial. Height 20 feet. Pkt. 10c.

XERANTHEMUM. A popular flower of the immortelle class, blooming freely in common soil. Plant is of compact habit with flowers borne on long stems. Colors: White, purple, yellow and light blue. Hardy annual. Mixed. Pkt. 10c.

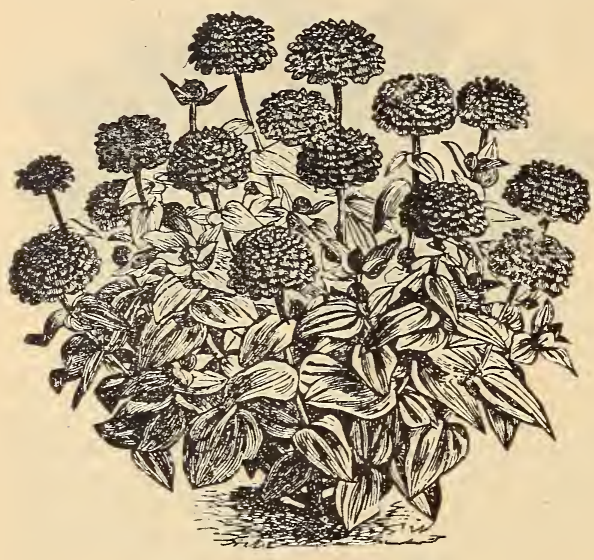

Ziunia Elegans, Double.

\section{ZINNIA ELEGANS FLORE PLENO}

Very few flowers have such a long period of popularity as has this old-fashioned Zinnia.

Fine, large flowers, of great variety of colors -red, rose, crimson, scarlet, purple, orange, white, and yellow; the flowers are full double as a Dahla remaining in bloom from July till after frost. Make a dense hedge, covered with bloom. Heigh 2 feet. Half hardy annual.

DOUBLE VARIETY MIXED. This is made up of the best and showiest double varieties. Pkt. 5c.

NEW ZEBRA. Striped like the animals of distant lands, the name of which it has. Pkt. 10c.

NEW MINIATURE ZINNIA. The most dainty and ornamental miniature Zinnia in existence. It is of truly Lilliputian growth., the plants growing from 3 to 4 inches in height only At the same time these pretty little plants display a perfection in leaves, flowers and growth generally, not often met with in this class of the Zinnia.

The mixture which we offer to our customers this year contains all the popular colors that can be found amongst the tall Zinnias, and the profusion of the blossoms make it an exceedingly showy variety in every garden.

Indispensable for borders around small flower beds, where larger plants would spoil symmetrical forms. The plants themselves are splendid adapted for bedding purposes, as they stand transplanting readily, and when in bloom some beautiful beds of finest color combinations can be created. Mixed colors. Pkt. 10c.

\section{SPECIALS}

Include at least one of these in your orders. It it money well spent.

MIXED CLIMBERS. Includes, Nasturtiums Sweet Peas, Japanese Hops, Cypress Vine, etc., just what you want to cover an old fence, stumps, terllises, etc. Pkt. 10c; 1/2 oz. 25c.

EVERLASTING FLOWER MIXED. All the popular everlastings. You cut them when in bloom, and they keep all winter. Pkt. 10c.

Don't miss our offer of plants, including roses, Ferns, Carnations, Geraniums, etc.

SUMMER FLOWERING BULBS. Order a few Gladiola, Tuberoses, or Caladiums and youll not regret it. Every August we issue a Fall Bulb Catalog. If you have not been receiving it, write for it next fall and set out a few Hyacinths and Tulips.

\section{SELECTED SUMMER FLOWERING BULBS FOR SPRING PLANTING} Prices are Postage Paid unless otherwise Noted.

CALADIUM ESCULENTUM. (Elephant's Ear.) One of the most effective plants in cultivation, for planting out on the lawn, growing 6 feet high with handsome leaves, of ten 3 feet long and 20 inches wide. Will thrive in any garden soil, but for best results should be set in good soil and given plenty of water. Should not be planted until soil is warm. Can be stored in sand during the winter. Large bulbs, each $25 \mathrm{c}$; doz. $\$ 2.50$.

CANNAS. Combining grand tropical foliage with large and brilliant flowers. The Canna is one of the most showy bedding plants. The large flowers and varied colors double their popularity. Each 10c; doz. 75c.

BEGONIA. Handsome young flowering bulbs of rich, varied colors, ranging from delicate yellow and salmon to crimson. Early bloomers, in full bloom untill early frost. Grow best in soil composed of leaf mould and sand and a small portion of well rottes cow manure. Single, each 10c; doz. \$1.00; double, each 15c; doz. \$1.50. 


\section{SELECTED SUMMER FLOWERING BULBS FOR SPRING PLANTING-(Continued)}

DAHLIAS. Always a favorite for autumn flowering. The flowers are symmetrical and perfect, and the range of colors are so varied and perfect that they will always be popular where display is wanted. Roots easily injured by frost. Set two feet apart. Tie to stakes. Show and fancy varieties $15 \mathrm{c}$ each; $\$ 1.00$ per dozen.

CINNAMON VINE. A charming climber with heart-shaped leaves and cinnamon scented flowers, making a perfect bower of beauty. It thrives anywhere, and when once planted will grow for years. They are grown from roots or tubers, and will grow in any locality. Each 5c; doz. 50c.

GLOXINIA. This plant is very ornamental on account of the richness of its foliage and its ample, graceful and delicately tinted flowers. The soil should be porous and very rich, and the bulbs, being small, should be planted shallow. They grow best in a warm, moist atmosphere, but to produce the finest colors they should be shaded, or grown in a northern exposure. Imported separate colors, each 10 c; doz. 90c.

WHITE CALLA. The Calla is one of the best flowering plants for room culture needing little care beyond abundant water, and an occasional washing of the leaves to keep them free from dust. Take a four-or five-inch pot, fill it with good, rich loam (one-half leaf mould and one-half good garden soil), then put in the bulb and cover one inch below the surface, water good and place in a dark place for three or four weeks. As soon as it starts growing bring to the light. Each $15 \mathrm{c} ; 3$ for $40 \mathrm{c}$.

TUBEROSES. Most delightful, fragrant and beautiful summer flowering bulbs. Flowers wavy, white and sweetscented. Plant is fond of light and heat. Plant outside after April 1. Each 5c; doz. 40c.

LILY OF THE VALLEY. The Lily of the Valley is a sweet little plant, thriving in any common soil; it will do well in any shaded situation where few other plants will thrive. Each 5c; doz.30c.

MADEIRA VINE. Madeira Vine is a popular and favorite tuberous rooted climber of rapid growth, with dense and beautiful foliage. It grows everywhere, but does better in warm, unny locations. Each 5c; doz. 40c.

\section{FINEST MIXED GLADIOLI}

In our opinion the right kind of Gladioli is one of the most beautiful and stately flowers. To a certain extent this splendid flower has been discredited by the sending out of so many inferior bulbs with the dull reds and other generally unsatisfactory colors. Our present mixture is made up from some of the finest named varieties; shades and colors never before sent out in a Gladioli mixture by any seed house. All cheap and inferior grades have been thrown out. The fine spikes of richly colored and brilliant bloom will both surprise and please you. Plant a dozen or more in your flower garden this year. Six for 20c; 12 for 40 c; 50 for $\$ 1.50$; 100 for $\$ 2.90$, postpaid.

LILIUM GIGANTEUM. The True Bermuda Easter Lily. This peerless Lily is the greatest acquisition to floriculture made in many years. Their profusion of bloom, the remarkably short time required to bring them into flower, and the certainty to produce abundant bloom, and also the ease with which they can be manipulated to be flowered at any desired period, such as Christmas, Easter and other special occasions, make them invaluable. Each 20c; doz. $\$ 2.00$.

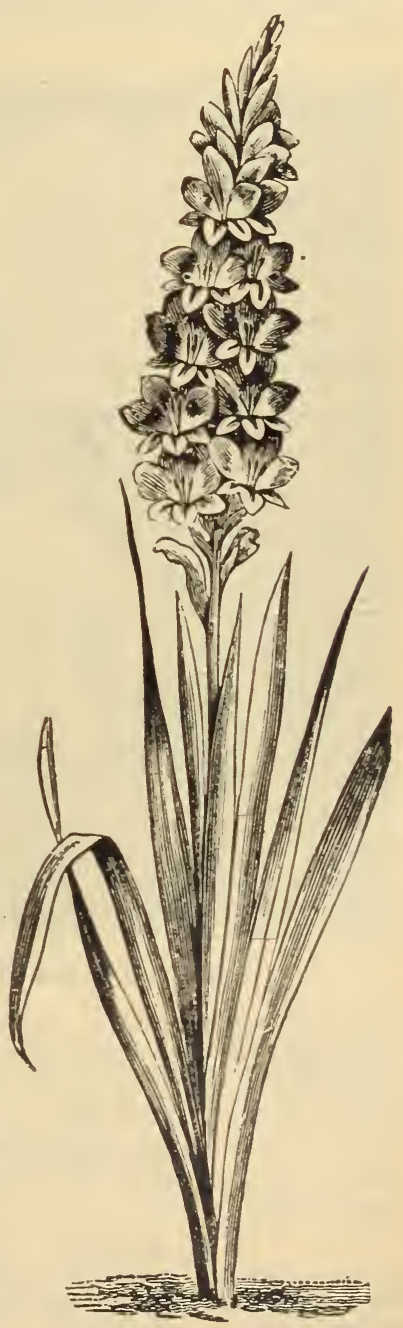

Gladiola. 


\section{ROSES}

\section{HYBRID PERPETUAL ROSES}

CULTURE. The Rose, the Queen of Flowers, being a heavy feeder, should be planted in a soil made as rich as possible and not too wet. Before planting incorporate in the soil when digging the hole, a shovel of well rotted manure and set your plant about one inch deeper than originally planted, spreading the roots and pressing the ground firmly about them. Plant the bedding kinds about $1 \frac{1}{2}$ feet apart, while the climbers are set from 3 to 4 feet apart. The best time to plant them is in December to April. During the summer months the ground must be cultivated to keep it free from weeds and to prevent it from baking. In the fall after the leaves have fallen off, the plant should be trimmed back to one-half the season's growth. A good dressing of old manure, or bone meal will insure a big yield of flowers next year. To prevent and destroy the rose chafer and rose slug, sprinkle the bushes as soon as the leaves are forming, and once a week after, with a solution of Paris green water: One pound of Paris green to 100 gallons of water. Mildew can be checked by dusting sulphur on the leaves every two or three days, and the green fly will soon disappear if tobacco dust is sprinkled under the leaves thoroughly before applying the powdered insecticides.

AMERICAN BEAUTY. Color red, with touches of crimson, and intensely fragrant. No Rose has a sweeter or more penetrating fragrance than American Beauty. A most beautiful Rose and a great favorite.

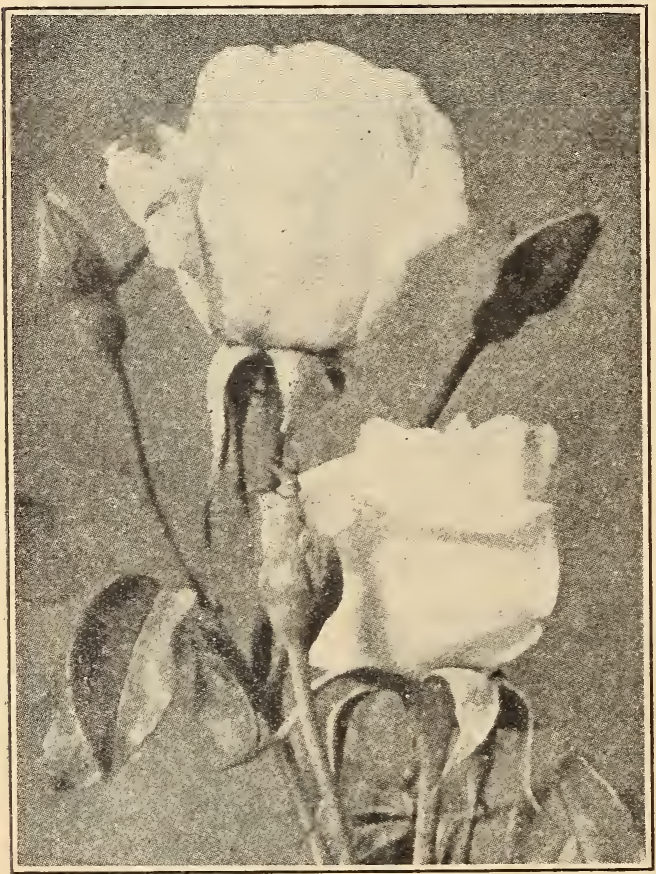

Kaiserin Augusta Victoria.

KAISERIN AUGUSTA VICTORIA. (H. T') White with lemon center; full, pointed buds; vigorous and a good bloomer; very double. This Rose is one of the newer sorts, with handsome, bright foliage. The flowers are borne on long, straight stens. A variety of great merit.

\section{LA FRANCE.}

The Queen of all the roses. Beautiful bright silvery-pink with palt lilac shadings, over the entire flower a satiny sheen. Large, full and fine form; one of the sweetest-scented Roses Most free blooming.

SUNBURST. A vigorous and healthy Rose, with long, pointed buds and splendid flowers, which are produced on strong, upright stems. The color is an intense orangecopper and golden yellow, extremsly brilliant in effect. A splendid variety. This rose always creates a sensation.

METEOR. Flowers rich, dark velvety crimson; plant strong clean, vigorous grower, like Bon Silene, but with flowers larger and more double. The richest colored ever. blooming Tea Rose yet introduced; very distinct, grows and blocms in remarkable profusion outside as a bedding Rose.

\section{CLIMBING ROSES}

CLIMBING AMERICAN

BEAUTY. Same color, size and fragrance as American Beauty, with the addition of the climbing habit. Good foliage, and better blooming qualities. One plant of this new Rose will produce twenty times as many flowers in June as the old American Beauty, besides blooming occasionally during the summer. Blooms three to four inches across; has proved perfect ly hardy and stands heat and drought as well as any Rose in our collection. This Rose has already made its mark, and wherever it has been planted it has pleased.

CLIMBING KAISERIN AUGUSTA VICTORIA. (C. H. T.) Also known as Mrs. Robt. Peary. A strong climbing form of the beautiful variety of same name now so well known. Pure white.

MARECHAL NIEL. (C. T.) This is the old standby yellow Rose in the South, where it is hardy; indeed, it will bloom in any garden, but is not hardy in the North. Immense deep golden-yellow flowers with the deepest, richest tea fragrance of all Roses. Anywhere in the South this Rose wil bloom in the garden throughout the summer. 


\section{CLIMBING ROSES-(Continued)}

CLIMBING BRIDESMAID. This rose is identical with its parent, the Bridesmaid, that standard, pink, cut flower rose of America, except that it is a strong climber. It grows rapidly and blooms as freely as does its parent; in color a clear, dark pink, the buds are beautiful beyond anything we have ever seen.

CLIMBING METEOR. This is the best dark red, ever-blooming, climbing rose. Foliage strong, healthy and luxuriant; flowers large, beautifully shaped and of that rich, dark velvety crimson color, seen only in Jacqueminot.

CRIMSON RAMBLER. This wonderful climbing rose was introduced about twelve years ago and has made an unequalled record. Perfectly hardy and very vigorous, making shoots 10 to 20 feet in height in one season. It is greatly admired for the display of its crimson clusters of blossoms.

\section{PRICES OF ALL ROSES, WELL ESTABLISHED PLANTS; 20c POSTPAID.}

\section{FERNS and PLANTS}

NEPHROLEPIS WHITMANII. (The Ostrich

Plume Fern.) A great Fern. In fact, it is a plant that appeals to everyone, and on that account will prove a much more valuable and profitable plant than the Boston Fern, which has had the most phenomenal sale of any decorative plant that has ever been grown, but which cannot be compared to the Ostrich Fern for beauty and general effectiveness. Everyone who has seen it is charmed with it. As someone expressed it: "There is nolling like the Ostrich Plume Fern in cultivation. In decorative effect it so far outdistances the original variety that there is positively no comparison to be made. We consider it the most valuable novelty that has been introduced in many years." It has taken gold medals wherever shown.

NEPHROLEPIS WHITMANII COMPACTA.

The Parlor Fern. This is a condensed form of the "Ostrich Plume Fern," with valuable characteristics added which are not evident in the parent; the pinnae subdividing, making miniature fronds which are superimposed on the main fronds, looking as if two or more were condensed in one. Graceful beyond description.

NEPHROLEPIS SCOTTI. The Newport Fern. Of much dwarfer and bushier growth than the Boston Fern. The fronds droop gracefully, and are not as long and heavy as the Boston. It is a rapid grower, and to see it in all stages of growth from a runner in the bench to a fourteen-inch pot specimen will convince you that it will be in great demand as a house Fern. This has always been a favorite variety.

NEPHROLEPIS PIERSONII. The Gold Medal Fern. This Fern received a gold medal from the Society of American Florists and Ornamental Horticulturists, and is the only go:d medal ever a warded by them for any plant whatsoever. An entirely new form of the Boston Fern. The pinnae subdivide, making miniature fronds which are superimposed on the main fronds, looking as if two or even three were condensed in one, giving the plant a graceful, feathery and plumy effect.

NEPHROLEPIS BOSTONIENSIS. The Boston Fern. In the vicinity of Boston no other plant is so extensively used as this graceful Nephrolepsis, which differs from the ordinary Sword Fern in having much longer fronds which frequently attain a length of six feet. These arch and droop over very gracefully, on account of which it is frequently called the Fountain Fern. This drooping habit makes it an excellent plant to grow as a single specimen on a table or pedestal. This Fern should not be compared to the Ostrich Plume Fern, as they are of an entirely different growth; both have their place and both are beautiful and desirable. 


\section{ASPARAGUS FERNS}

ASPARAGUS SPRENGERI. A fine variety for hanging pots. The rich foliage will droop in its natural grace. Plants also blossom freely and bear large red berries. Nothing finer for decorating.

ASPARAGUS PLUMOSUS NANUS. Fine, lace-like foliage, compact and most exquisite. A grand foliage plant. Splendid for table and house decorations, bouquets, etc.

Prices of all Ferns, strong, young plants, 25 cents, postpaid.

\section{CLIMBING VINES}

ANTIGONON LEPTOPUS or MOUNTAIN ROSE. (King's Crown.) A lovely climber from Central Mexico, with beautiful rose-colored flowers in racemes two feet long. The profusion of bloom is such as to give the resemblance of Roses at a distance, hence the Mexican name "Rosa de Montana," or "Mountain Rose." Described by its discoverer as the most beautiful climber he had ever beheld. This is moderately hardy with protection. The vines are killed to the ground by frost, but it quickly shoots up in the spring, and develops its flowers from June till frost. Each 20c, postpaid.

AMPELOPSIS VEITCHII. Boston Ivy. This is one of the finest climbers we know for covering walls, as it clings firmly to the smoothest surface, covering it with overlapping leaves, which form a perfect mass of foliage. The color is a fresh, deep green in summer, changing to the brightest shades of crimson and yellow in autumn. It is quite hardy and becomes more popular every year. Each 15c; 2 for 25c, postpaid.

\section{HONEYSUCKLES}

HALL'S JAPAN. The most constant bloomer of the class, being literally covered all summer with beautiful yellow and white flowers.

SCARLET TRUMPET or RED CORAL. A rapid grower, bright red, with trumpetshaped flowers. This is the old, well-known variety.

YELLOW TRUMPET. Same as Scarlet Trumpet, only flowers are golden-yellow. Each $15 \mathrm{c} ; 2$ for 25c, postpaid.

GERMAN OR PARLOR IVY. A rapid-growing and succulent plant, well adapted for covering trellis work quickly or training in the parlor. Leaves glossy green and flowers yellow in clusters. Each 20c, postpaid.

VINCA MAJOR VARIEGATA. This is a beatiful variegated trailing vine admirably adapted for hanging baskets and vases. The leaves are a glossy green, broadly margined a creamy-white, flowers blue. More Vincas are employed in vase and basket work than all other vines combined. Each 20c, postpaid.

\section{GENERAL LIST OF PLANTS}

GERANIUMS. The improvement both in size and beauty of this flower has been wonderful. We offer the very best varieties to be had. Mixed colors. 10c each; 3 for 25 c, postpaid.

VERBENA. Among the best known and most easily grown annuals, making an excellent color display as bedding plants, or in window boxes. Dozen 50c.

PHLOX DRUMMONDII. Mixed Drummond Phlox. Their various colors and length of flowering, with easy culture, make them favorites with every one. One foot high. Dozen 25c.

SALVIA SPLENDENS. 10c each; doz. 75c.

VIOLETS. Single, blue. doz. 25e.

CARNATION. Mixed. 10c_each; doz. $\$ 1.00$. 


\section{ALFALFA}

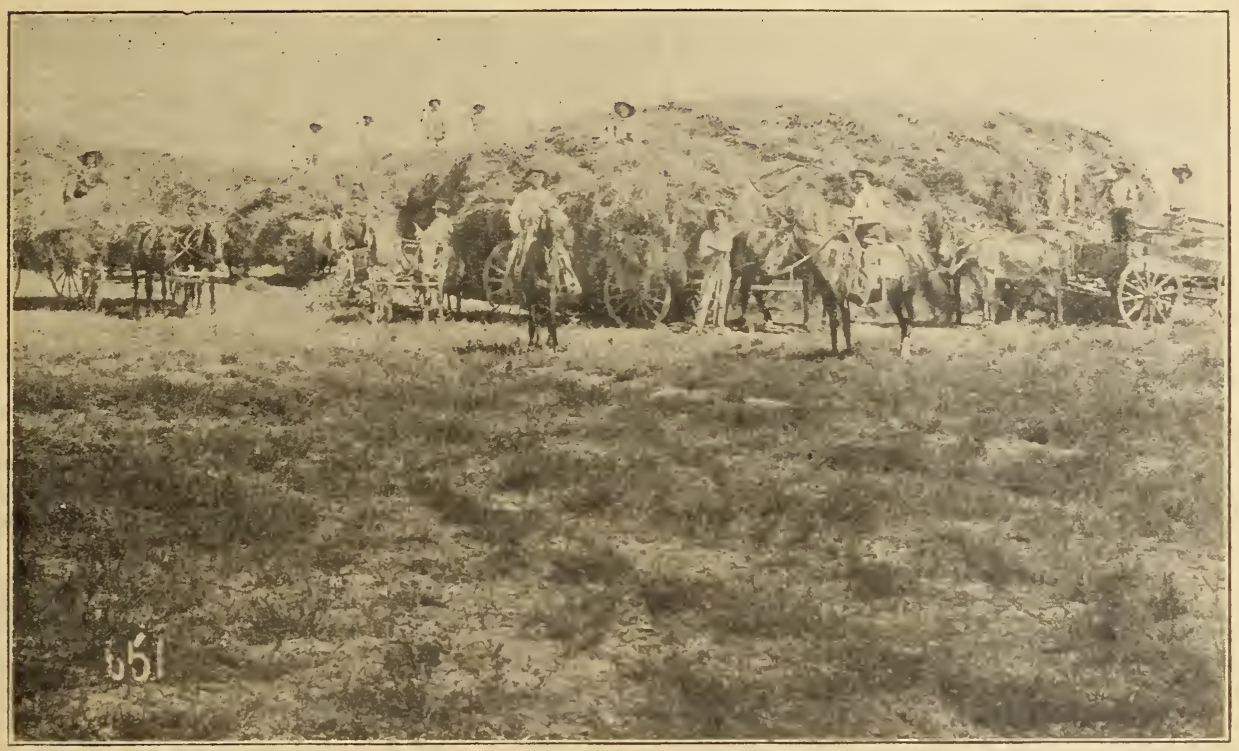

\section{THE BEST MONEY-MAKER ON THE FARM}

ALFALFA OR LUCERNE CLOVER. Alfalfa is the most talked of and most widely planted of all 'he varieties of clover in the world.

The U. S. Department of Agriculture says:" In addition to the hay crop, Alfalfa at two years adds $\$ 100$ to the value of every acre on which it grows. There is no State in tye Union in which Alfalfa cannot be successfully grown." This is saying a good deal, but it has proven true.

Alfalfa in the South will produce 5 to 7 tons of hay to the acre each year and in money value is worth $45 \%$ more than other clovers and $60 \%$ more than Timothy hay. It will grow 4 or 5 crops a year and it does not exhaust the soil; it enriches the soil. Its long, branching roots penetrate far down, 15 to 20 feet, and so loosen the subsoil that it is a gigantic subsoiler, resists drought, and gets plant food where other crops would be a failure. When the plants are destroyed in order to raise other crops on Alfalfa Land, the large roots decay and produce a vast source of fertility to be used by following crops.

It is said that the feeding value of a ton of alfalfa is equal to a ton of shelled corn.

Many other interesting facts might be given about Alfalfa. We can't say too much for it because it's a working plant which is changing the destiny of may farming sections. No farmer in the South with stock can aflord to let it go without a trial.

Although fall sowing is preferable, good results can be obtained form early spring sowing. Give it care and attention, especially the first year, and your trial will show you that you cannot afford to be without it. Get it thoroughly established by first preparing your land, applyiny plenty of lime, and before seeding you should innoculate the seed. If your land has never had Alfalfa growing on it before be sure to innoculate the seed with nitrogen gathering bacteria for Alfalfa, for without innoculation your success is exceedingly doubtful. The Alfalfa bacteria, which are necessary, sell for $\$ 2.00$ per one acre bottle. Full directions for use come with each bottle; see page 95 . When once established, Alfalfa is the most valuable permanent clover that can be grown. It is adapted to almost the entire South and has the highest feeding value of any hay. Do not sow on wet ground, high and rather dry being preferable, and only cut when coming into bloom.

Do not buy cheap Alfalfa seed. If it's cheap, it is not pure Alfalfa but is mixed with weed seeds. Weeds are very troublesome to Alfalfa, crowding it out and ruining the quality of your hay, so be sure to get the highest grade seed and no other brand. This is absolutely essential to success.

Sow in thoroughly prepared soil, either broadcast or in dirlls, at the rate of 20 pounds per acre,

We sell only the highest grade seed, $98 \%$ purity or over, and all of it is the strongest American grown seed on the market. Price 25 cents per pound. !eck and bushel prices subject to market changes. When ready to buy write for prices.

FOR BEST RESULTS ALFALFA SHOULD BE INNOCULATED WITH FARMOGERM. SEE PAGE 95. 
All prices are subject to market fluctuations. Our prices include sacks, but do not include freight or express charges, which must be paid by customers.

POSTAGE.- On small lots please add 5c. per lb. postage. On large quantities add regular parcel post charges. See page 2

\section{CLOVERS}

WHITE FLOWERED SWEET CLOVER. (Melilotus Alba.) Sweet Clover has suddenly sprung into popular favor. For a long time it had been regarded as a pest, but now a place has been found for it and in its place it is a very valuable plant.

Sweet Clover is valuable because of its ability to grow and thrive on the poorest and most barren places. It will not only thrive on soils that are too poor for any other crop but will improve the soil it is growing on. It makes good hay and good pasture, although cattle do not always take to it at first. It resembles Alsike Clover in that it can grow on moist soils.

Its ability to improve the soil, together with its ability to thrive on very poor soils, makes it especially valuable as a pioneer crop on poor, run down, badly washed fields

The seed can be sown either in the fall or spring and about $20 \mathrm{lbs}$. of the hulled seed and 25 lbs. of the unhulled seed is required per acre. Per lb. 25c.

ESPARSETTE or GERMAN CLOVER. (Onobrychis sativa.) Perennial, blooms in July. Same family as alfalfa, adapted to light chalky soils, stands gravel and barren regions deficient in rainfall. Shorter lived plant than alfalfa, but will last from 8 to 10 years, according to soil, by judicious top dressing of manure. It is excellent for cows increasing flow and quality of milk. Would advise early and heavy seeding. Follow with roller. Sow seed 2 inches deep and from 30 to 40 pounds per acre. Per lb. 25 c.

MAMMOTH SAPLING or PEA VINE CLOVER, Being a rank grower makes it most valuable for fertilizing purposes. Foliage, flower and stem much darker than common Red Clover, ripens later than the latter, about the time Timothy, Red Top and other grasses ripen, making thereby a much better quality of hay, when mixed with them. Sow 12 to 15 pounds to the acre. Per lb. 30c.

ALSIKE CLOVER. (Trifolium hybridum.) Alsike Clover is especially valuable for growing on wet or swampy land. If you have a piece of land that is too damp for Alfalfa or other clovers or grass sow a mixture of about four pounds of Alsike Clover and ten pounds of Red Top Grass Seed. This will make an excellent crop of hay.

Alsike Clover is very hardy, is perpetual, will withstand drought and will not winter kill. About six to ten pounds will sow an acre and as the seed is very fine it should be covered only slightly. For bottom lands needing drainage but not subject to overflow an excellent mixture is as follows: Four pounds of Red Clover, two pounds of Alsike Clover and ten pounds of Timothy. This quantity is for one acre. Lb. 30c.

RED CLOVER. (Trifolium pratensis.) Red or Medium Clover has long been considered the most important of the clover family. It is valuable both as a hay crop and a pasture crop, and is also beneficial to the soil. It is a well known fact that grain crops will yield more when they follow clover. It is very valuable for enriching worn-out soils but the trouble is that the soil is generally too much exhausted before the clover is sown. The better plan is to rotate your crops with clover so that the soil will not become too badly run down.

The common mixture both for hay and pasture is eight pounds of Clover and ten pounds of Timothy per acre. To get the best hay Red Clover should be cut when just past the blooming stage, but in consideration of a second crop it is often necessary to cut the first crop a little sooner.

The selection of the seed is of greatest importance. Buckhorn is found in nearly all clover seed and is to be avoided whenever possible. Our Columbine Grade is especially selected for purity and can be depended upon.

Red Clover will grow on any good corn land and when sown by itself the soil should be put in first class condition. It can be sown either in the spring or in the fall, but as it is not drought resistant in the early stages the moisture should be conserved as much as possible. It is generally sown broadeast at the rate of 12 to $15 \mathrm{lbs}$. to the acre. Per lb. 30c.

WHITE CLOVER. (Trifolium repens.) White Clover is excellent for pasture and is especially valuable for mixing with Kentucky Blue Grass both for lawns and pasture. A few pounds of White Clover should be in all permanent grass seed mixtures as it helps fill up the bare spots and is very nutritious. White Clover will disappear at the approach of very hot weather, but will come back again with rains or seasonable weather. It is very hardy and is a perennial. Sow five to eight pounds per acre. Per lb. 60c.

CRIMSON CLOVER. (Trifolium incarnatum.) An annual variety in common use in Italy and southern France for feeding green. Also largely grown in this country in Virginia. A good portion is now being used in Texas and adjoining states. Two to four weeks earlier than the Red Clover, and for that reason being more desirable. Immense yielder of fodder. Commences to grow at once after cutting and continues to do so until after frost. Height 1 foot; roots nearly black, and blossoms long and of deep carmine color. Makes good hay. Sow in the fall in southern country. Sow 15 pounds to the acre. Per lb. 30c. 


\section{CLOVERS-(Continued)}

BURR CLOVER. (Medicago Maculata.) Is used mainly in the Southern states and in California. Fills in the season when other forage plants have become dried up by the summer heat. Stock of all kind feed upon the burrs, which contain a large portion of nutritious matter. Sow 15 to 20 pounds per acre in August, September or October. Per lb. 20c.

JAPAN CLOVER. (Lespedeza atriata.) Low, perennial, spreading habit. Stands exceessive drouth well; flourishes on poorest soil in southern states. Sow 15 pounds per acre. It makes a fair bay, and stock eat it readily when green. It is also valuable for turning under as green manure. Sow in spring broadcast at the rate of 30 pounds per acre. Per lb. 35c.

\section{FARMOGERM}

\section{High-Bred Nitrogen-Gathering Bacteria for Clovers, Alfalfa, Peas, Beans and Other Legumes.}

FARMOGERM stands by itself as a very high bred culture of nitrogen bacteria for treating seeds. It gives quicker growth, larger and healthier stands and earlier maturity. It will enrich the soil for future crops and increase the permanent value of the farm.

FARMOGERM comes all ready to be placed on the seeds to give you very profitable returns, with practically no labor, as the seeds for 10 acres can be inoculated in just a few minutes.

You should use FARMOGERM without fail each year, and we assure you that you will find it the best investment that you ever made.

Put up for the following crops, excepting mixed clovers:

Alfalfa or Lucerne, Red Clover, Mammoth Clover, Crimson Clover, Alsike Clover White Dutch Clover, Burr Clover, Sweet Yellow or White Clover, Japan Clover, Garden Peas, Canada Field Peas, Sweet Peas, Cow Peas, Soy Beans, Velvet Beans, Garden Beans, Lima Beans, Windsor Beans, Vetch (Spring and Winter), Peanuts, Beggar Weed and other Legumes. See Page 95.

\section{WRITE FOR PRICES ON LARGE QUANTITIES}

\section{GRASSES}

\section{Make More Grass in 1918}

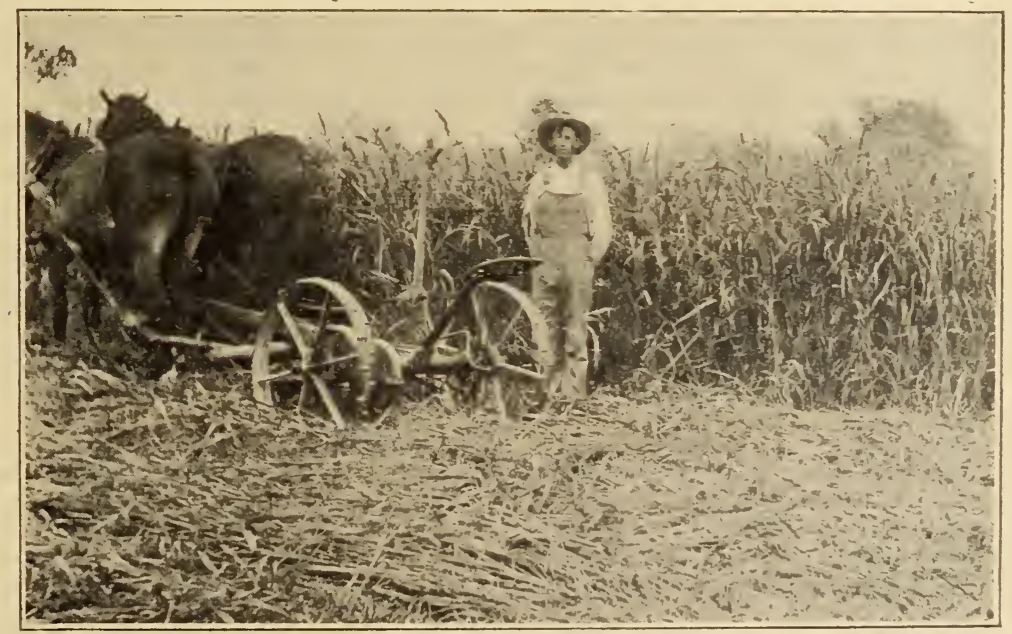

Sudan Grass, Ferd. J. Rock Ranch, Uvalde, Texas.

SUDAN GRASS. The great hay and forage crop. This wonderful new Grass seems to be taking the country by storm. This grass has been grown very extensively in Texas the past season and has been tested out in a numbr of other states and the verdict is unanimous everywhere it has been grown it spells success. It seems to grow successfully on all kinds of land, stands dry weather and does not blight under ample rainfall. Sudan Grass is thought to be the original wild form of the cultivated sorghums. It is an annual, the Seed having to be sown every year. It looks very much like Johnson Grass when growing but has a different root growth. 


\section{GRASSES-(Continued)}

Johnson Grass reproduces itself from undergroung root stalks as well as from the Seed. Sudan Grass Seed will not sprout from the roots after frost has killed the plant. Ranges in height from five to ten feet, stems small and somewhat more leafy than Johnson Grass. Like the sorghum crops, it must be planted it Spring and dies when the frost comes. The number of cuttings each season, therefore, depends on length of the season. Usualy matures in ninety days from planting. Next crop is usually ready for haverting thirty days from first cutting. At Cnillicothe, Texas, four cuttings were had in one season, averaging slightly more than one ton per acre to each cutting. Its feeding value marks it easily as one of the dependable crops of every farmer Stock of all kinds eat it readily and will leave other kinds of hay to eat it. Makes a splendid silage crop. In arid districts, it is usualy planted in rows 36 inches apart. This requires 4 pounds of seed per acre. It is also sown broadcast where the rainfall is ample, requiring from 20 to 25 pounds of seed per acre. Lb. 30c. Ask for prices on large quantities.

RHODES GRASS. We are more than glad to offer to our trade this splebnid new variety of Grass seed. It is very seldom that a new grass appears that it is specially valuable.

For the Gulf Coast sections all around the lower Rio Grand Valley, above Brownsville, Texas, we believe that Rhodes Grass will peove the most valuable drass ever introguced.

Rhodes grass came originally from South Africa, but is better known in Australia, where it has been grown for a number of years with success and has became a standard and much prized variety.

In the Australian State of New South Whales the conditions are quite similar, we believe, to those which we have here in the Southern States.

Its best points are:

1. It smothers nut grass. 2. It is good grass for green feed.

3. It is excellent grass for hay. 4. It is a rapid grower. 5. It has fibrous roots so it is not likely to be a nuisance, since it can be reradily be eadicated, if required. 6. The seed germinates readily. 7. It runs six or eight feet and then grows erect. 8. It is very palatable to stock.

Stock eat Rhodes Grass greedily, either as hay or in its green state. It stands a fair amount of frost, will do with less moister than perhaps any other grass that has been introduced into this country, and last but not least of its excellent qualities, is that it will smoother Nut Grass Price lb. 50c, per $100 \mathrm{lb}$. $\$ 45.00$.

BERMUDA GRASS. (Cynodon Dactylon.) Almost everybody living in this section of the country knows this grass; it is planted as a lawn grass, and nothing will stand the sun better or will make a prettier carpet, when kept short, than this grass. It is also very valuable as a pasture and hay grass. It is only of late years that we have been able to obtain the seed of this grass, which heretofore had to be propagated bu the roots, 6 pounds will sow an acre. Should be planted in the Spring, but can be also sown later. Under the most favorable circumstances it takes from 60 to 90 days to sprout; requires damp weather and hot sun; but when once up it grows very rapidly. Used extensively by levee contractors for planting in new levees. 6 lbs. to the acre. Lb. 75c.

BROMUS INERMIS or HUNGARIAN BROME GRASS. A Wonderful Drouth Register. A Grass for the Stock Raiser. All Cattle Like It. This pre-eminent drouth-resisting grass stands at the head of all, and is destined to lead as the most satisfactory and valuable forage grass in all localities where arid soils demand a plant with ability to stand the drouth. Stands intense cold equally as well. May be sown on autumn with winter wheat, or early in spring. In southern states sow in February and March, preparing lands as for other grasses. Blooms in north in June, and earlier in southern states.

Its nature is to stool out, and thus does not show its best until the second season. It seldom produces seed the first year. Aside from Alfalfa no grass has fulfilled the promise to the western farmer better than Bromus Inermis. It meets drouth as well as wet and cold, and for Texas we know no grass to equal it. Many of our large ranchers are planting it extensively.

For hog pas turea mixture of Bromis Inermis and Alfalfa, where the latter succeeds well, is recommended by Prof. Ten Eycke of the Kansas State Agricultural College Experiment Station, and he also suggests for large pastures for cattle a mixture of the following per acre: Bromis Inermis, 10 lbs; Orchard Grass, 3lbs; Meadow Fescue, 8 lbs; Red Clover, 1 or 2 lbs; added to the mixture For worn out pastures he advises a disc early in the spring, following with a harrow and sow Bromis Inermis on the land, putting most on places where native grasses are most killed out. Lb. $25 \mathrm{c}$.

Seeds go at parcel post rates. Allow $5 \mathrm{c}$ per lb. for small lots and regular parcel post charges for larger quantities.

WRITE FOR PRICES ON LARGE QUANTITIES. 


\section{GRASSES-(Continued)}

ORCHARD GRASS. (Dactylis glomerata.) No farmer should be without a small field of Orchard Grass as in many respects it is superior to all other grasses. It stands the drought, grows well in the shade, does well in wet or poor ground and is splendid to prevent worn out fields from washing. This grass furnishes excellent pasture three weeks before any other and after close grazing ten days rest is sufficient for another growth. Cows fed on this will produce more and richer milk than on blue grass. It makes a very heavy sod and when well set remains for many years. It is especially adapted for winter grazing, as it remains green all season. It is well suited to sow mixed with alfalfa; an average of $12 \mathrm{lbs}$. Orchard grass 6 to $8 \mathrm{lbs}$. alfalfa seeds. Sow 20 to 25 lbs. per acre. Lb. 30 c.

KENTUCKY BLUE GRASS. (Poa pratensis.) This is the standard grass in America for lawns and also for pastures. Blue grass is the base of practically all grass seed mixtures. It is perhaps a little slower than some other grasses but when once established it is permanent. It thrives best on limestone land. Sow 25 to 30 pounds per acre for meadows, and 60 to 80 pounds per acre or one pound for every 150 square feet for lawns. Per lb. 30c.

RESCUE GRASS. Most valuable as a pasture grass for high and dry situations. The nutritive quality of this grass cannot be surpassed and it is exceedingly relished by horse and cattle. Per lb. 25c.

ITALIAN RYE. (Lolium Italicum.) Surpasses the perennial rye grass in earliness and nutrition and rapid growth. Indispensable for alternating. Lasts only two years, and of no use for permanent pasture. Particular as to soil, a moist, tenacious, fertile and of medium consistency being considered the best. On such it is considered one of the best grasses cut green. Sow 30 to 40 pounds to the acre. Per lb. 20c.

TALL MEADOW OAT. (Avena elatior.) The roots of this descend deeply in to the subsoil, enabling it to withstaind a protracted drouth, and it is green all seasons of the year. Its early growth in spring makes it equal to rye pasture. It grows quickly after mowing giving a denser and more succulent aftermath than any of the present popular cultivated grasses. Sow broadcast 25 to 30 pounds of seed to the acre. Per. 1 b. 25c.

PASPALUM DILATUM. From Australia. Just the thing to reclaim marsh-lands, and equally good to survive drought. It has been to the Australian dairyman what alfalfa is to the California dairyman. It survives extreme cold, and in Southern California it grows the year round, thus insuring green all winter.

Mr. Sullivan. dairyman of El Monte, planted it on land too wet and soft to allow his cattle to pasture upon it. Alfalfa would not survive. He sowed Paspalum on ridges between alfalfa checks. The first season only demonstrated it would grow throughout the winter. The second season proved its worth. It had seeded to a wonderful degree. The seed grew, taking root among the weeds and devil grass, choking out everything in its way. The dense tufts of grass made a thick mat capable of supporting the cattle. Mr. Sullivan cut it three times during the season, each time getting about one ton of dry hay to the acre. The stock relish it fully as well as alfalfa. It makes a fine hay free from any wood It is as easy to eradicate as timothy or any other bunch grass. Seven pounds are required to plant an acre. Price $-\$ 1.00$ per $\mathbf{l b}$. prepaid. Write for quantity price.

PERENNIAL ENGLISH RYE. Lolium perenne.) While this has long been highly esteemed in Europe and Australia, it has but recently been recognized by our western ranchers. It is worthy of all the praise given. As a pasture grass it grows thick and withstands drouth reasonably well. We have reports of its success as far south as Mexico City and in the far west, also in Old Mexico it is used extensively for lawns. Our new crop is carefully cleaned, and may be depended upon. For pasture sow in spring 2.5 to 30 pounds to the acre. Fow lawns 60 to 75 pounds to the acre. Lb. 20 c. $\$ 15.00$ per $100 \mathrm{lbs}$.

MEADOW FESCUE or ENGLISH BLUE GRASS. (Festuca pratensis.) Especially adapted for permanent pasture. Grows 2 to 3 feet high, but not in tufts like orchard grass. Earliest and most nutritious of grasses. Makes good hay: cattle thrive on it whether in dry or green state. Succeeds even on poor soils, and as the roots penetrate deeply from 12 to 15 inches, it takes extremely dry weather to affect it. Will stand more freezing than any other variety, and yields an abundant crop of seed. Heretofore has been sown to but a limited extent, but the area is rapidly increasing each year. Sow 15 to $20 \mathrm{lbs}$. per acre. Lb. 25c.

LAWN MIXTURE. We consider this mixture better than stragiht Blue Grass. It is made principally of Kentucky Blue, White Clover, English Rye, Bermuda and some other grasses that will growrapidly and make a good showing immediately. These coarser grasses will also protect the Blue Grass and let it get a good start.

The Kentucky Blue Grass and White Clover will eventually drive out the other grasses and make a fine lawn. This Sunflower Lawn Grass is made just as good as po know how to make it and we have had forty years experience with grass seeds. Lb. 30c. 


\section{GRASSES-Continued}

NATAL GRASS. A distinct, strong-growing grass for Texas and all the Lower South. In the extreme South this grass is perennial and can be used for permanent pastures, but where it becomes frozen during the winter it will have to be seeded each year. As an annual it cannot become a pest, like Johnson Grass, but it gives a very heavy growth for a hay crop. Four tons to the acre can easily be made and it is a sure cropper. It resembles the great Sudan Grass in appearance and productiveness so you may rest assured that you will have a barn full of hay if you plant Natal Grass. In feeding value it is nearly as valuable as Timothy and can be cut two and three times a year. Seed is very light and fluffy and requires about 10 pounds per acre for perfect stands. Natal Grass has been grown in Texas in a limited way over 20 years and is cut all through the summer and fall. It is a heavy yielder and much easier to cure than Sorghum or cowpeas. Plant in the spring as soon as danger from frosts is over, and we believe you will continue to plant it in the years to come. Try it on a large scale this year. It grows well as far North as Virginia on light soils, making heavy tonnage, and that's what we want for hay. Prices: 4-ounce pkt., 35c; lb., $\$ 1.00$, postpaid. Write for quantity prices.

TIMOTHY. (Phleum pratense.) As a crop of hay Timothy is probably unsurpassed by any other kind of grass. It is greatly relished by all kinds of stock, especially horses; yield more nutritious matter than any other forage plant or grass. Being an early grass it is well adapted to spring and summer grazing too. Sow 10 to 12 pounds to the acre. Lb. 10c.

JOHNSON GRASS. (Sorghum Halapense.) We find this grass winter kills in the northern states. A perennial, a rapid grower with long cane-like roots; the leaf stalk and pinnacle of this grass resemble those of sorghums. It is grown on any land where corn will grow. Ten pounds will sow an acre. Lb. Ask for prices.

WILD RICE. (Zizania Aquatica.) An annual which sows itself in the fall about the middle of September, lies dormant in the winter, and in the spring commence to sprout as soon as the water gets warm, reaching the surface about the first of June. It grows very rapidly in 1 to 4 feet of water, reaches a height of 7 to 10 feet and ripens late in August or early in September. It does well along the shores of marshes, and makes good hay. In the south two crops can be cut and all cattle are very fond of it. Lb. 30c.

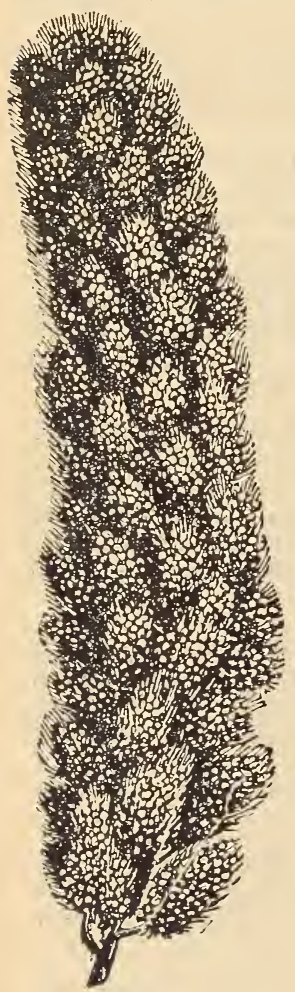

Millet

SWEET VERNAL. (Anthoxanthum Odoratum.) Yields a moderate amount of herbage, which is remarkabe for its pleasing fragrance during the drying of the hav. Mix with other grass seeds for lawns or permanent pasture. Sow 3 to 5 pounds to the acre. Lb. 40c.

\section{MILLETS}

COMMON MILLET. It is an annual grass with juicy, tender and luxurient leaves, much relished by all kinds of stock; makes good hay. Sow 25 to 40 pounds to the acre. Lb. 10c.

GOLDEN MILLET. An enormous yielder. It has produced 4 to 5 tons of hay to the acre, and from 70 to 80 bushels of seed. It is sown in the spring on newly broken prairie, and after harvesting it leaves the ground in the finest condition for wheat. Sow 25 to 40 pounds to the acre. Lb. 10c.

HUNGARIAN MILLET. It is of fine growth and makes excellent hay. It has numerous succulent leaves, which furnishes abundance of green fodder, taken by all kinds of stock. Sow 25 to 30 pounds to the acre. Lb. 5c.

MANITOBA or HOG MILLET. The seed is very rich and thus especially valuable as a hog food. A very much prized peculiarity of this millet is that the seed ripens while the stem is yet green, thus if cut promptly can be threshed for the seed, while the hay, after being threshed, will make excellent fodder. Sow same as other millet. Lb. 10c.

JAPANESE MILLET. Or "Billion Dollar Grass," as it is sometimes called, is of recent introduction, and great claims are made for it as to productiveness and value as a forage plant. Prof. Brooks, of the Massachusetts Experiment station, is quoted as saying: "At our station it produces 60 bushel of seed. 11,297 pounds of straw, 36,000 pounds of green fodder, 12,000 pounds of hay per acre, being superior to good corn fodder in feeding for milk, and in combination with the soja bean makes a very superior ensilage. Recommended highly for feeding dairy cattle, young stock and sheep, being very rich in nutritious elements. If sown in the latter part of April will be ready to cut hay for by the middle of July. Attains a height from 5 to $71 / 2$ feet, according to season. In drills plant 10 to 12 pounds per acre broadcast, 15 pounds per acre. Lb. 10 c.

Ask for prices on larger quantities. 


\section{MILLETS-(Continued)}

PEARL MILLET or PENCILLARIA. Immensely productive, 25 tons per acre. A native of Central America. It is an annual plant having long, broad foliage, and if allowed to develop fully will attain a height of from 10 to 12 feet, and bear numerous heads from 19 to 20 inches in length and 1 inch in diameter, completely covered with thousands of seeds, much relished by poultry. It is of rapid growth, throwing out from one plant numerous suckers, and if cut as soon as it reaches the height of 2 to 3 feet, it can be mowed from 4 to 6 times, according to the latitude, and yields several tons of hay to. the aere. If allowed to grow 6 or 7 feet high, and cut when the flower heads begin to develon, it will yield the heaviest fodder crop per acre of any plant now in cultivation. For feeding it is equal to any fodder and is relished either green or dry, by all kinds of stock. Lb. 20c.

SIBERIAN or RUSSIAN MILLET. It is claimed to be the most wonderfully productive and satisfactory forage plant, possessing in a superior degree all of the essential merits of any of the older sorts-exceeding them by far-besides many other points of excellence that distinguishes it and render it a most valuable addition to the list of forages. If the claims are well founded it is destined to take front rank, if not to lead all the rest. Lh. 10c.

Put a top dressing of our pure bone meal on your pasture. The result will surprise you.

Seeds go at parcel post rates. Allow $5 \mathrm{c}$ per lb for small lots and regular parcel post charges for larger quantities. See page 2

\section{WRITE FOR PRICES ON LARGE QUANTITIES}

\section{TEXAS GROWN SEED CORN}

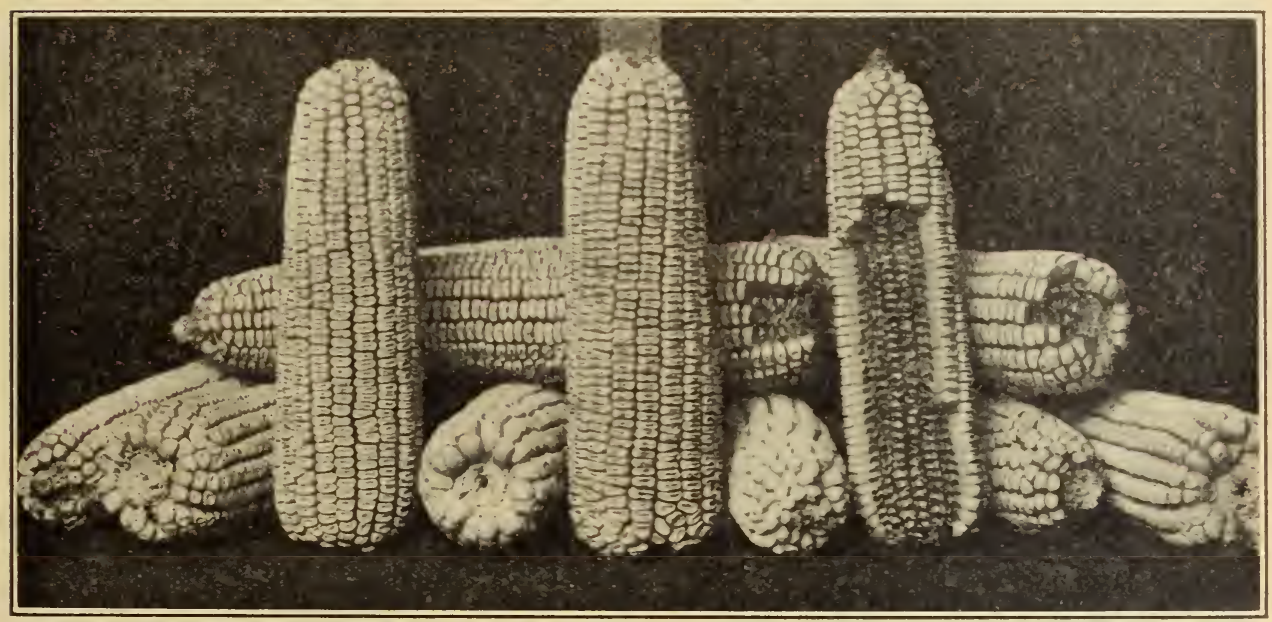

Texas White Ninety-Day Corn

TEXAS WHITE NINETY-DAY CORN. Needs no recommendation for a general field crop, being tested, tried and proven very satisfactory. Lb. 10c.

NATIVE GROWN JUNE CORN. (MAIS CHINACO). Introduced by us over a quarter of a century ago from Montemorelas, Mexico. It was then called Chinico; the proper name is Chinaco, meaning outcast. We think this is the grandest Outcast ever brought into this country. It is plantable Spring, Summer and Fall, maturing in 90 days and making roasting ears in 70 days. Lb. 10 c.

NATIVE SQUAW CORN. A drought-resisting variety plantable in the summer months. It has blue and white grains, therefore not so desirable by the market gardener. However,it makes a sweet and very juicy roasting ear. Price: Pint Lb. 10 c.

ACCLIMATED STRAWBERRY CORN. Good all around corn, more especially for feeding purposes, originating from the crossing of red, white and yellow stock. This gives it a very pretty appearance. Lb. 10c.

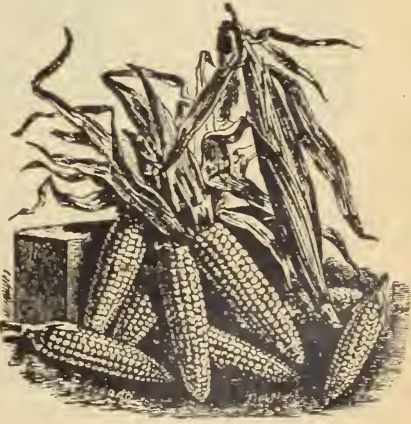

Mais Chinaco. 


\section{SEED CORN-(Continued)}

SURCROPPER CORN. A truly remarkable drought resisting power. As old as is the history of corn-growing in the South and Southwest is the search for a corn able to hold up and make a crop on the scanty moisture which we have in so many fields at some period of almost every season. In Surcropper we have found that corn.

This remarkable corn first forced itself upon our attention in the memorable dry season of 1901. when the efforts of so many Texas corn growers were rewarded with total or partial failure. Surcropper made a good crop. Since that time it has had a brilliant history of success after suecess under dry-season conditions. In a comparative test with a number of other varieties at Austin, it made a crop in a season so dry that the other varieties did not even tassel. Its success under average conditions has been almost equally as notable. Lb. 10c. Write for prices.

\section{YELLOW VARIETIES}

ORDER EARLY. Our seed corn is all selected, tipped, butted and shelled. And above all it is tested for vitality and we know it will grow. Quality in seed corn is of great importance and if you want a good yield you must first have a good stand, and to get a good stand you must have seed of good vitality. Our seed corn is tested and can be depended upon.

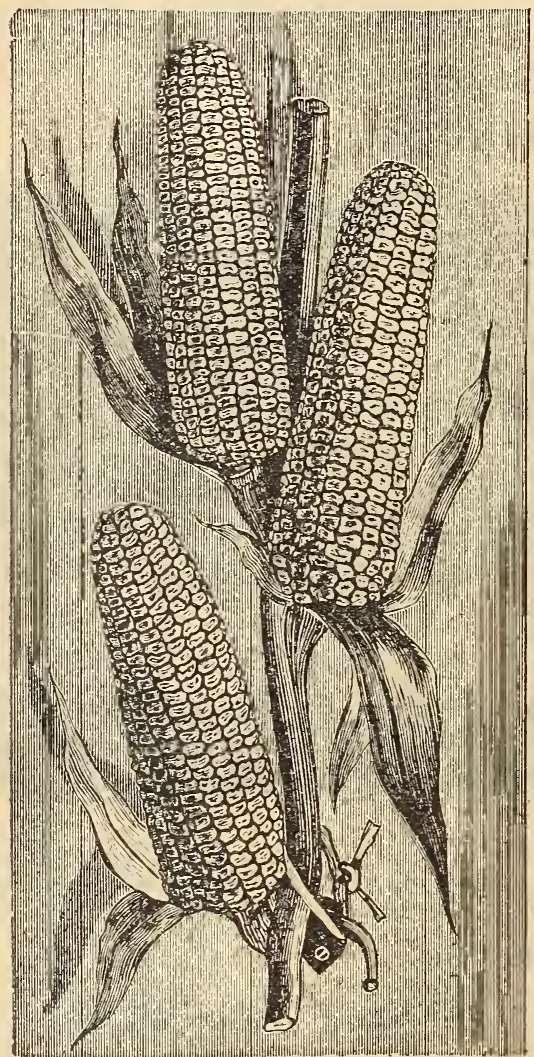

Kaw Chief.

KAW CHIEF. The Result of Thirty Years of Selection. It took thirty years to produce Kaw Chief Corn. This is absolutely the best corn we have ever raised, and we are proud to offer Kaw Chief Corn to our customers. We raised a good crop in spite of the drouth, and have a nice lot of seed to offer.

The corn is of a deep golden yellow color, the ears are large, measuring up to 13 and 14 inches in length and have 16,18 and 20 rows to the cob. The grower had in mind constantly not so much a very large ear, but an ear that was well filled at both top and butt, and kernels that were long and square shouldered. This is the kind of corn that yields heaviest when shelled. A bushel of Kaw Chief Corn on the ear will yield 58 to 60 pounds of shelled corn.

Kaw Chief Corn matures in from 95 to 105 days, and ordinarily yields from 75 to 80 bushels per acre and makes a good growth of foliage. It does well on both upland and bottom land.

We would advise you to plant some of this excellent variety and would suggest that you order early as our supply of Kaw Chief is very limited this season. Lb. 10c.

IMPROVED LEAMING. (90 Days.) This is one of the earliest yellow dent corns in cultivation, ripening in 90 to 100 days from planting, surpassing the yellow Canada and flint varieties in earliness, productiveness and quality. The ears are large and handsome, with deep, large grains; orange, yellow color and red cob. Stalks medium sized, tapering gradually, producing two good ears, each of which husks and shells easily. Lb. 10c.

\section{REID'S YELLOW DENT. (100 Days.)}

Ears medium size, remarkably uniform in size and of a light yellow color, with a deep grain and small red cob. Best for shredding, as it shatters least of any. A sure cropper and a very reliable variety in all respects. Lb. 10 c.

GOLDEN BEAUTY. (100 Days.) The ears are of perfect shape, with from ten to fourteen straight rows of bright golden yellow grains, remarkable in size and filled out completely to the extreme end of the cob. The richness of color and fine quality of grain make it vastly superior for grinding into meal. The giains are of a hard, flinty nature, neither are they so soft as to be greatly shriveled. The ears are easily shelled, although the kernels are firm on the ear, and in every respect as perfect a type as could possible be had. Golden Beauty matures in 100 to 110 days from plantingand surpasses all in size and beauty of grain. Lb. 10c.

HILDRETH YELLOW DENT. (100 Days.) This corn is a very large growing. variety. The ear is large and well rounded at butt and tip. The kernels are inclined to be small, but are very deep. Indentation medium rough; color deep golden yellow. Lb. 10c; $1 / 4 \mathrm{bu}$. $\$ 1.10$

Our Corn is Southern grown. The varieties we sell are adapted to southern conditions and are the very best you can plant. 


\section{SEED CORN-Continued}

\section{RED CORN}

BLOODY BUTCHER. (110 Days.) This corn resists the drouth better than any other variety. Ears long and of perfect shape. Grain deep red, having sometimes a yellow tip. Type is not entirely fixed. Lb. 10c.

\section{WHITE VARIETIES}

SILVER MINE (90 days.) The stalk grows to a height of 7 or 8 feet, and set the ears about three and a half to four feet from the ground. The ears measure from ten to twelve inches in length. They are very uniform in size and shape, sixteen to twenty straight rows of deep, pure white kernels, on a small cob. It is the heaviest yielder we know, having yielded over 100 bushels to the acre. Seventy pounds of ears will make sixty-two pounds of corn. It is entirely distinct and will give satifaction. Lb. 10c.

CHAMPION WHITE PEARL. (100 days.) The stalk is short and thick. The ears grow long on the stalk, from seven to twelve inches in length, almost parallel throughout, of medium size, averaging sixteen rows of grains. The grains are pure white, very deep, compact and heavy. The cob is small. By a test seventy ears weighed eighty-seven and one-half pounds, of which the cobs alone weighed only seven pounds. It makes superior quality of corn meal. We recommend it highly. I.b. 10c.

HICKORY KING. (110 days.) This is an entirely distinct variety amongst the white corn, combining the largest grain with the smallest cob. A single grain will completely cover the cob of an ear broken in half. It is a great yielder, giving more shelled corn to the acre bulk of ears than any other varity. It is satisfied with any kind of soil, and will produce good strong stalks, bearing two, and occasionally three good ears. A good drouth resister. We recommend it very highly. Lb. 10c.

HASTINGS' PROLIFIC. Hastings' Prolific Corn is a wonder in production of both grain and forage. It is the most prolific corn we have ever seen, the yield of grain and forage being enormous. It makes more ears and better ears, with longer, deeper grains. Hastings' Prolific average 16 to 18 rows. It has deep grains very closely set on a very small white cob. Sixty-five pounds of corn in the ear shells out one bushel or more. Grains rather flinty and a good keeper. Lb. 10c.

GIANT WHITE RED COB. Makes a very large ear of the finest corn. Grains very large, deep, wide and thick, cob red, very popular wherever tried. We recommend this as being the finest variety of White Red Cob Corn. Has a very large, deep, wide, thick grain. Ears of medium size. Matures in one hundred to one hundred and ten days. If you want a first class corn, you will make no mistake in planting the Giant White Red Cob. Lb. 10c.

CHISHOLM CORN. Chisholm is a very attractive variety because of its large, sound, deep, white, oily grains that completely cover a bright red cob. The ears are large size in favorable seasons, but if by chance very unfavorable conditions make them small, even the nubbins will show large attractive grains. Ears are stout, covered by a coarse, heavy shuck which protects the ears thor oughly. Lb. 10c.

BRAZILIAN or STOOLING FLOUR CORN. This corn, as the name indicates, is inclined to stool, and one grain will produce in many instances more than one stalk. Each stalk bears two or three ears five to seven inches in circumference, nine to twelve inches in length and beautifully white. It produces an abundance of fodder, and is the best variety for ensilage. It yields 30 to 50 bushels o corn per acre, and the ears are fine for roasting although not sweet. It does not require a very rich soil and therefore the best variety for poor soils. The kernel contains more starch than any other corn, and ground and bolted by the same process as wheat, gives a fine flour that will make bread, biscuits, etc., the same as the wheat flour. Plant two kernels in a hill and cultivate the same as other corn. Three pounds will plant one acre. Lb. 15c.

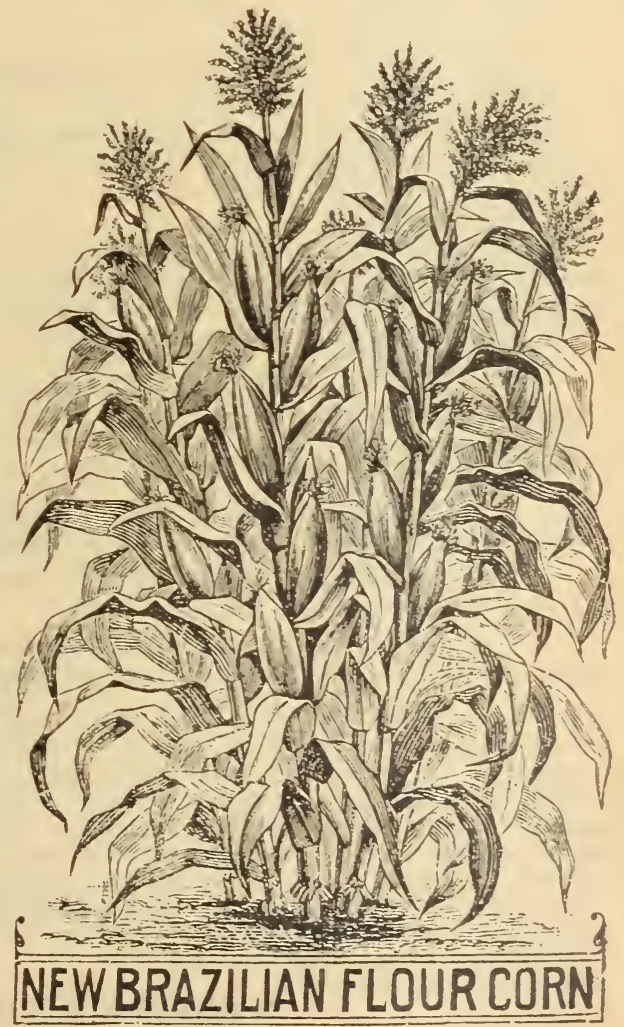




\section{FORAGE PLANTS}

DWARF ESSEX RAPE. Main standby of the English farmer in raising choice mutton. Perfectly hardy and of remarkable fattening properties. Easily grown. One acre will pasture 36 head for two months, lambs will make a gain of from 8 to 12 pounds per month. Pigs and cattle are also extremely fond of it. A very rank grower and bears heavy manuring and high cultivation. Sow at intervals of several weeks and secure a supply of good feed. Sow in June. Rape should be fed in August, though if a first crop be cut about four inches from the ground an after growth would be useful later. Does well sown with oats. If soil is clear and clean sow broadcast, otherwise in drills, and cultivate same as corn. Poultrymen will do well to sow a small patch to feed green to growing chicks. Can be sown on wheat stubble, furnishing excellent pasture late in the fall. Broadcasted it takes 8 to 10 pounds to the acre. Lb. 25c; Ask for prices on larger quantities.

AUSTRALIAN SALT BUSH. (Atriplex semibaccata.) The department of agriculture of California recommends this very highly for planting on alkali soils. They claim thousands of acres of arid and alkali land have been reclaimed by the use of this plant. The plant is of spreading habit, branching freely and making a thick mat of stems and folage. The plant needs some moisture to start a growth but when once started it can stand the hottest and dryest weather. Should be cut and cured same as clover Pkt. 5c; oz. 15c; $1 / 2$ lb. 75c; lb. \$1.25.

LUPINS. When young the plants are good for sheep, yellow Lupins remaining green longer than white. One of the best plants for soiling. May be sown from April until July and succeeds well in the poorest soil. Lb. 25c.

TEOSINTE. Recommended as the most prolific forage plant yet introduced. The stalks containing much saccharine matter, are very nutritious. It can be cut several times during the season, yielding enormously. One seed will sometimes produce 20 to 60 stalks or shoots, and the warmer the climate the better it yields. Should not be planted until the soil is perfectly warm in the spring. Requires about 4 pounds of seed to the acre. Plant in drills three feet apart and two or three seeds every 12 inches in drill. Oz. 15c; $1 / 2$ lb. 75c: lb. $\$ 1.25$.

\section{SACCHARINE SORGHUMS}

Cane or Sorghum is planted very extensively both for syrup and for fodder. It makes an immense amount of the finest kind of fodder which is relished by all kinds of stock. The Texas Seeded Ribbon and the Orange varieties are commonly used for making syrup, and the Amber and Red Top varieties for fodder.

Cane makes excellent pasture and when grazed down will spring up quickly again. It should be sown in the spring and will do well on thin land. Sown broadcast it requires from 1 to $11 / 2$ bushels per acre, and if in rows from 6 to $10 \mathrm{lbs}$. per acre.

Cane will make a good crop of fodder if sown as late as the middle or even the latter part of July.

TEXAS SEEDED RIBBON CANE or GOOSENECK SORGHUM. This variety makes the most and the best quality of syrup. Growers who have used it for that purpose are enthusiastic about it. The stock is not entirely pure and both Goosenecked and straightnecked plants appear in the same fields. Lb. 15c.

EARLY AMBER CANE. This popular and well known variety is the earliest and makes the finest quality of amber syrup and sugar. Succeeds well from Texas to Minnesota. Lb. 10c.

ORANGE CANE. A well known variety adapted to the southwest. It is from 8 to 10 days later than the Early Amber. Lb. 10c.

RED TOP CANE. Planted very extensively in the southwest. Smaller than the other varieties, but makes a large amount of fodder. Lb. 10c.

JAPANESE HONEY DRIP RIBBON CANE. This is a large, stocky and vigorous variety, maturing in 120 to 125 days. It sends up two to four stalks, which reach a height of eight in fourteen feet. The stalk is as large or larger than Gooseneck, and in quality it compares equally well to Gooseneck-to either of which all Sorghum can be compared in regard to sweetness. The seeds are plump, slightly larger than Sumac, and when hulls are removed Seeds appear to be a dull reddish-brown color; and after the threshing process, are almost totally enclosed in a bluntly pointed, glistening red glume; heads are long and medium loose. This variety is lately introduced into Texas, where fields last year produced 350 gallons of the very best quality of syrup to the acre. This syrup is lighter in color and milder in taste than that of Sumac, Orange or Amber. Make the very finest kind of silage. Lb. 15c. 


\section{FORAGE PLANTS-(Continued) BROOM CORN}

There are many farmers who make this a most profitable crop. One acre will produce $500 \mathrm{cwt}$. of brush and nearly 40 bushels of seed, which is almost equal in value to oats for feed. Requires soil similar to corn, same cultivation, but should be planted some later in the season. Put in ground in prime condition. We think that more of our western farmers should grow Broom Corn for market. It is profitable. Frequently planted in drills $3 \frac{1}{2}$ feet apart. leaving 6 inches apart; 5 to 10 pounds to an acre.

THE OKLAHOMA DWARF BROOM CORN. Originated in Oklahoma. Most valuable strain grows here and in the Southwest. Quite distinct from all others in earliness. Of robust habit and extreme productiveness; brush long and well fibred, and is a drouth resister. On new breaking it does splendidly, leaving the ground in prime order for fall wheat crop, only slight discing needed to prepare for seeding. Averages five feet in height, making it convenient for pulling brush. It is a great yielder; one of our Texas growers reports several fields yie!ding 1 to 3 tons fine long brush; seeds may be left to ripen on brush without injury to latter, removing danger of heating from immature seed bins. Stalks make excellent fodder if cut at once after brush is pulled. Lb. 10c.

\section{NON-SACCHARINE SORGHUMS}

\section{They Stand Dry Weather}

These varieties are especially valuable for their ability to withstand dry weather. Many farmers are trying, year after year, to raise corn when they do much better by raising such crops as Kaffir, Milo, Feterita, etc. These varieties will all yield as much grain as corn, will make excellent fodder; but the best point is that they will make a good yielder under conditions under which corn would burn up entirely.

It is a well known fact that when these grains are struck by dry weather they simply stop growing for the time being, and when they get more rain they go ahead and make their normal growth.

They make good material for filling silos and should be planted much more extensively especially in the regions of deficient rainfall.

They should be planted in rows like corn, planting about five pounds per acre, and cultivating like corn. They will grow on any corn land and also on land too poor for corn. The crop should be cut and shocked when the seed begins to glaze.

FETERITA. Feterita grows about five feet high on an average, and a crop of it growing looks very much like a crop of kaffir or dwarf white milo. The heads grow up straight like kaffir and about twice the size. The grain is softer than kaffir or milo grain and is liked better by all kinds of stock. Feterita matures from 40 to 60 days earlier than kaffir and is therefore well adapted to countries with short seasons, or can be grown as a second crop where the seasons are long, after the wheat or oat crop. After being tested in Western Tesas for three vears, it has been found a much greater drouth-resister than kaffir or milo. Last year, the dryest year the farmers of Texas have ever experienced, with less than three inches of rainfall for the entire year, Feterita grown by the side of kaffir or milo produced from 40 to 50 bushels per acre, while the kaffir and milo produced from 10 to 25 bushels. This year there is a difference of from 15 to 25 bushels in favor of Feterita. Feterita has the same feed value for feeding all kinds of stock or poultry that kaffir or milo has. Lb. 10c.

WHITE KAFFIR CORN. It makes a straight upright growth and has a strong stem with enormous wide leaves. The stalks keep green and are brittle, making excellent fodder, either green or dried, which is highly relished by cattle and horses. The heads form at the top of each stalk. For the grain sow in rows 3 feet apart, 3 to 5 pounds of seed to the acre. For fodder sow one-half to one bushel, either broadcast or in drills. Lb. 10c.

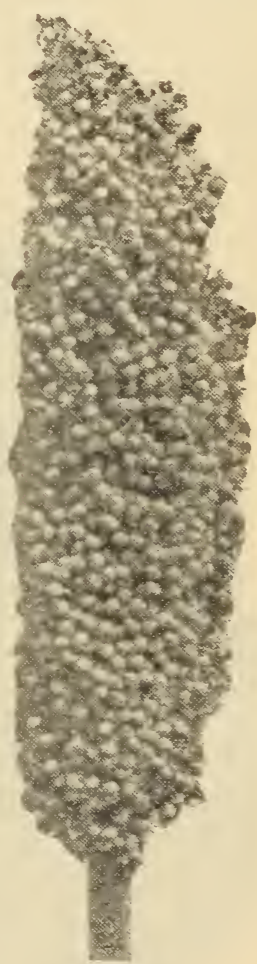

Feterita

SCHROCK KAFFIR SORGHUM. This a comparatively new grain which was originated in Oklahoma and has been planted in Texas for several years. It is claimed to be one of the finest of the sorghums for forage and ensilage, as it is quite sweet and grows an abundance of broad, long leaves. It is a wonderful grain to stool out, not unusual for one seed to send up six to ten stalks, each making a fine head of large, light brown grains, which make an excellent stock and poultry food, one of the best drought registers of the sorghum family. Our seeds are acclimated. Drill at the rate of 3 to 5 pounds per acre. Price: lb. 15c. 


\section{FORAGE PLANTS-(Continued)}

RED KAFFIR CORN. This grows taller than the white; the stalks are more slender, but more juicy and very leafy. The heads are long, slender, compact, and grow very erect; they measure from 8 to 15 inches. The seed is red, smaller than that of the white, and rather hard and brittle. It does well on poor land and yields well. It ripens a little earlier than the white variety Lb. 10c.

DWARF BLACK-HULL WHITE KAFFIR. There has been a constant demand the last four years for Dwarf Kaffir corn. This year we are able to supply it. The value of the Dwarf Kaffir over the tall is apparent. In the first place the Dwarf Kaffir can be harvested with a grain header. By being able to harvest Kaffir in this manner a considerable saving in labor is effected. In the second place plants of dwarf stature expose less surface to the sun, and therefore can get along with less water. Lb. 10c.

SHALLU OR EGYPTIAN WHEAT. This grain grows something like Broom Corn. It stools out from the root, making from three to six stalks. It has been planted in almost every section of Texas and has produced splendid crops. It is very productive, making an enormous yield of grain and fodder, and has given great satisfaction to every grower. Shallu or Egyptian Wheat should be sown in drills three feet a part, using from five to ten pounds of seed per acre. Lb.10c

HEGARI, THE NEW GRAIN SORGHUM. Some years ago when Kaffir Corn, Milo Maize and Feterita were introduced into the dry-land farming crop catalog many people probably imagined that the limit in grain sorghum development had been reached; but that is almost certainly a mistake. We have abundant reason to hope for greater things yet. The new grain Sorghum Hegari, while it is too recent an introduction to justify settled conclusions, certainly promises in some respects, to out-merit all of its predecessors. Lb. 15c.

JERUSALEM CORN. (White Durra.) It is pronounced the best and surest grain crop for dry countries and seasons even better than Kaffir Corn, Dourrha and Milo Maize. It grows about five feet high, makes o,e large head on main stalk and several smaller heads on side shoots. Have seen as high as eightnheads on one plant. The grains are pure white, and nearly flat. Three pounds will plant one acre. Lb. 10c.

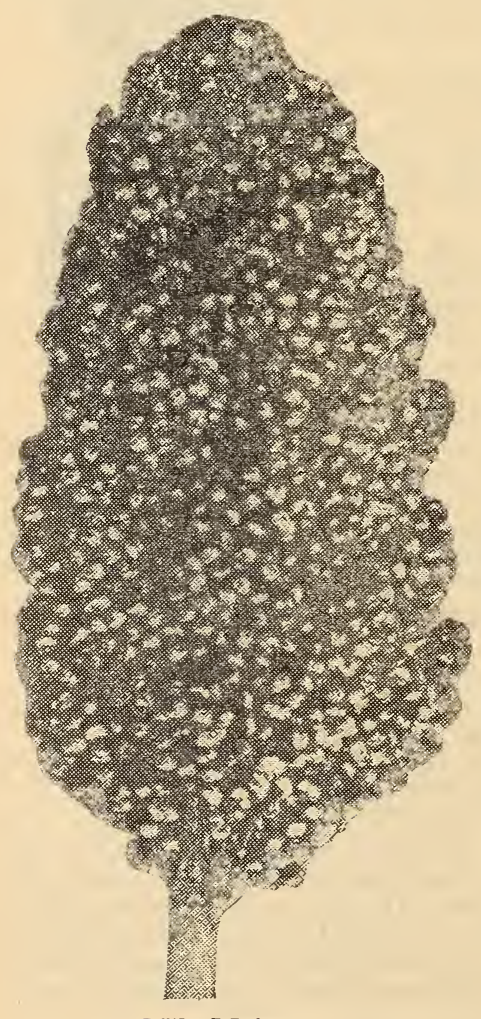

Milo Maize

DWARF STRAIGHT-NECK MILO. Dwarf Milo was thoroughly tested by the drought of 1913 and it stood the test. What would have you given last fall for a field of Dwarf Milo yielding about 50 bushels per acre?

The original Stock Seed was obtained from the U. S. Department of Agriculture and has been carefully selected and acclimated. It differs from the Standard Milo Maize in being dwarfed, growing from 3 to 5 feet high according to the a mount of rainfall, and it is straight necked. The advantage of this straight-necked feature is apparent in gathering, feeding and cutting the heads. This strain is earlier than Kaffir Corn and Standard Milo Maize. The yield is from 60 to 100 bushels per acre. This will stand great drought and for this reason is admirably adapted to dry land farming.

The Dwarf Milo Maize should be planted the same as Kaffir or Milo and cultivated the same as Indian corn. It can be fed in bundles or in head to work horses, cattle and hogs. Stock seem to prefer it to corn, and it has a laxative effect on them, keeping them in good condition.

While our stock is especially selected for straight necks, owing to the constant tendency to revert to the crook necked type, there will be a few crook necked in the field. Lb. 10c.

WHITE MILO MAIZE. - This new grain which was introduced about three years ago is gaining favor very rapidly on account of the fact that it shows it can stand a great deal of dry weather and still produce a first class crop. As dry a year as the past has been, a farmer in West Texas writes that he made a crop which produced nearly one hundred bushels of seed per acre. It is claimed that the White Maize is about ten days earlier than the Yellow and is more drouth resisting, and that it will make a crop with very little rain. One seed has produced as many as eight stalks, producing eight well-matured heads. It usually grows about five feet high. About eight to ten pounds of seed are required to sow an acre in drills. There promises to be an enormous demand for this splendid grain this season and we would, therefore, strongly recommend our customers placing their orders early before the supply is exhausted. Lb. 10c. 


\title{
FORAGE PLANTS-(Continued)
}

YELLOW MILO MAIZE. (Milo.) Growth is tall, 9 to 12 feet, stooling from the ground, like White Milo Maize, but not so much. It sends shoots also from the joints. Seed heads grow to great size, often weighing $3 / 4$ of a pound, sometimes a full pound after ripening. On account of its branching habits this grain should be planted in rows 4 to 5 feet apart, and 2 to 3 feet in the drill, or 2 plants in a hill, 3 to 5 feet apart. Lb. 10 c.

\section{FIELD BEANS, PEAS AND COW PEAS}

\author{
COW PEAS
}

\section{Improve the Soil.-Fine Fodder.-Excellent Ensilage.-Proof Against Chinch Bugs.}

Cow Peas belong to the same family as clover and taking the nitrogen from the air they have the same ability to improve the soil. The decaying roots and stems add to the soil and the whole vine can be plowed under for fertilizer.

Cow Peas have many uses. They make fairly good human food, they make gond pasture, can be fed green, make fine hay, make excellent ensilage especially when grown with corn, and improve the soil at the same time.

Cow Peas are very easily planted and easily grown. They are tender, however, and should not be planted until the ground is thoroughly warm. For fertilizer, pasture, or hay crop they should be planted broadcast or better still drilled in with a grain drill planting about a bushel of seed to the acre. If they are being raised for seed they should be planted in rows about thirty-sis inches apart and cultivated two or three times.

Cow Peas will grow on almost any soil and they are valuable for planting on thin land as they will make a good crop and also improve the soil.

Cow Peas are generally planted either broadcast or in drills by themselves and can be planted on wheat land after the wheat is taken off. Another common practice is to plant Cow Peas in between the rows of corn after the corn is laid by. It is rather difficult to cut the Peas and Corn when planted in this manner and the Cow Peas are therefore generally pastured off in the fall.

The very best forage or ensilage is obtained by planting corn and Cow Peas together in the row. This should be done at late corn planting time when the soil is good and warm. The corn should be about 12 to 14 inches apart in the row and the Cow Peas 4 to 6 inches. This can then be cut with a binder.
We carry the following varieties:
NEW ERA. Lb. 10c.
BLACKEYED. Lb. 15c.
CREAM or LADY. Lb. 20c.
WHIPPOORWILL. Lb. 10c.
CROWDER. Lb. 10c.

\section{WRITE FOR PRICES ON LARGE QUANTITIES}

\section{INOCULATE THE SEED}

And Help the Crops Grow the Highest Priced Plant Food

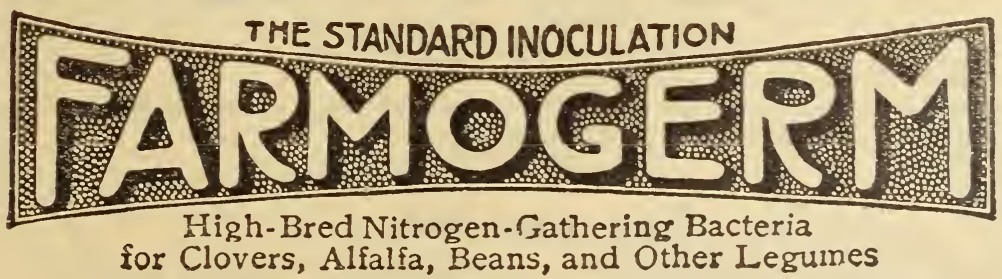

\section{TO BUILD UP WORN SOILS, INCREASE CROPS AND REDUCE FERTILIZER EXPENSE}

The growing of legume crops for soil enrichment is advocated by agricultural experts and experiment stations everywhere. The great fertilizer value of legumes depends entirely upon perfect inoculation. You can secure satisfactory results only by the use of Farmogerm inoculation, which has been practically tested for years and its efficiency proved and recognized the world over.

It is delivered in bottles ready for use. The seed for ten acres can be perfectly inoculated in ten minutes. Our customers who have used Farmogerm in past years strongly endorsed it, and we recommend every planter of legume seeds to

USE IT ON ALFALFA, PEAS, ClOVERS, BEANS, COW PEAS, VETCH, SOY BEANS, VELVET BEANS, PEANUTS, SWORD BEANS. 


\section{INOCULATE THE SEED-(Continued)}

Not only will the crops be larger and richer, but the soil will be plentifully supplied with nitrates for next year's crops. Further particulars upon application.

REGULAR FARM SIZE, or 5-ACRE _._.

FARM TRIAL SIZE, or 1-ACRE

GARDEN SIZE, or $1 / 4$-ACRE

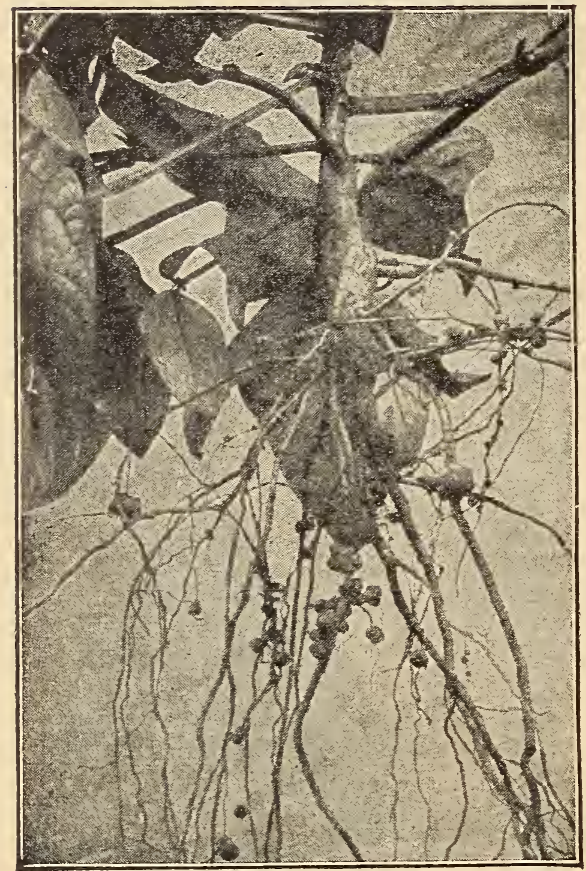

Nitrate sacks on the roots of Cowpeas. This fertilizer value is the result of the use of Farmogerm.

\section{SOY BEANS}

The Soy Bean is a legume, and in nutritive value is equal to red clover. As a soil improver, it is excellent. This plant will grow on a wide variety of soils, but the richer the soil the larger the yield of forage. Prepare the soil the same as for corn. Drill the Soy Beans in, from three pecks to a bushel and a half of seed per acre, after corn planting time. The heavier seeding is where the crop is grown for hay or pasture. A common drill can be used with the oat feed opened, and enough of the holes stopped up to give the proper distance between rows.

Soy Beans, as feed, takes the place of oil or gluten meal. Feeding them to milk cows, fattening hogs or cows, they have given astonishing results. If sown broadcast use one-half to one bushel per acre. We have the early Yellow, Late Mammoth; this last variety, however hardly ever matures north, but is all right for the southern states.

EARLY YELLOW SOY BEANS. Lb. 15c.

LATE MAMMOTH SOY BEANS. Lb. $15 c$.

TEPARY BEANS. A Drouth-resisting Bean raised by the Indians in Arizona. Prof. Clothier of the University of Arizona says: "After three years of experimenting with the Tepary Bean I am prepared to say it is one of the most wonderful plants ever presented to the dry farming public."

Tepary Beans will make a fair crop in 75 days and a good crop if they have 90 day If it is struck by a drouth it will ripen the pods already set and when the drouth breaks it will set and ripen a new crop.

Under ordinary dry farming conditions they yield from 450 to $700 \mathrm{lbs}$. per acre. The beans are white, cook well, have a delicious flavor.

They have been grown by Indians for thousands of vears without irrigation with an annual rainfall of 9 inches. Lb. 25c. Not postpaid, lb. 20c.

\section{FIELD PEAS}

CULTURE. Field Peas deserve more general cultivation. They are equal to corn in fattening hogs and are ready for feed several weeks earlier. Can be sown advantageously with oats or will do well alone. As a land fertilizer they are very beneficial. For such the crop should be plowed under when they begin to bloom. They will grow on most any kind of land.

WHITE SEEDED GOLDEN VINE. Pkt. 5c; lb. 15c.

GREeN SEeded CANADA. Pkt. 5c; lb. 15c.

Ask for market prices on large quantities.

Seeds go at parcel post rates. Allow 5c per lb. for small lots and regular parcel post charges for larger quantities. Sae page 2 . 


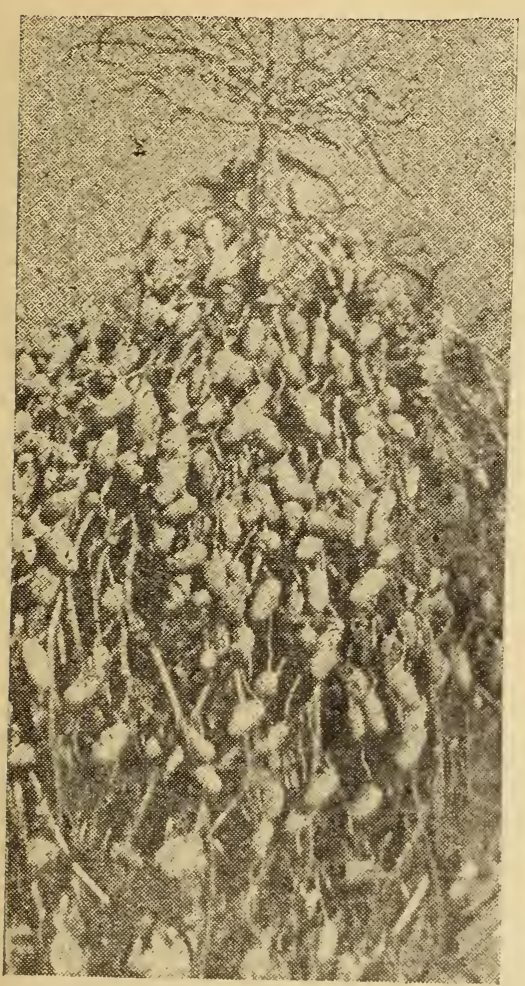

Spanish Peanuts

\section{PEANUTS}

The tops of the plants make good hay, and in the southern states it brings a very good price. The yield, even in dry seasons, is from one-half to three-quarters of a ton of hay and from fifteen to sixty bushels of nuts per acre. The whole peanut plant makes nice feed for forcing cows to a high yield of milk and for rapidly fattening cattle and hogs, especially when combined with grain of Milo. A common method of harvesting is to let the hogs gather the nuts. The Spanish Peanuts are generally planted when wanted for farm use. The nuts are small but they stand dry weather better.

Peanuts do best in light sandy loam. They should be planted in rows from 28 to 36 inches apart and from 9 to 16 inches apart in the row. They need not be shelled but should be soaked in warm water for a day or so and then planted at once in warm soil. Planting should not be done until weather is good and warm. They should be cultivated and kept clean until they begin to peg or form pods. After that they should be left alone.

It takes from one peck to a peck and a half of shelled nuts and from a bushel to a bushel and a half in the shell to plant an acre.

WHITE JUMBO. This is the standard variety for roasting. The peanuts are three times as large as those of the ordinary Spanish peanut. The nuts proper grow in fine double jointed hulls of beautiful white appearance, are from $1 / 2$ to one inch in length, and of fine flavor. An excellent variety worthy of the highest recommendation. Lb. $25 \mathrm{c}$.

TENNESSEE RED PEANUTS. This is the best of all varieties adapted to the soil of Oklahoma and Texas. Pods contain four and five large nuts. Better yielder than any other variety. Lb. 25c;

SPANISH. The earliest variety grown, pods are small, but remarkably well filled and solid, and tivated with the plow. Because of its early habit and easy yield per acre is very large. Can be cultivated with the plow. Because
cultivation it is the best variety to grow for fattening hogs. Lb. 15c.

SAND VETCH. (Vicia Villosa.) Sometimes called Hairy Vetch or Winter Vetch. This is one of the most valuable plants for forage and fertilizing purposes. It will succeed and make a good crop on good land. It is perfectly hardy throughout the United States and remains green all winter. Vetch belongs to the same family as Alfalfa and Sweet Clover, and has the same ability to gather nitrogen from the air and store it in the root sys te $m$. The roots are very extensive and add a good deal of valuable material to the soil. It thus improves the conditions and the productiveness of the land for the crops to follow.

It is an excellent catch crop, makes good hay, silage and pasture. Vetch can be sown from July until Novebmer, and should be sown broadcast at the rate of about 30 lbs. per acre together with one bushel of either oats or rye. Vetch grows quite tall and needs the oats or rye for support. They then make a better growth, and are more easily harvested and cured. For a hay crop the Vetch should be cut just after the Oats or Rye has headed out. The yield of green fodder is immense. Lb. 25c.

SPRING VETCHES OR TARES. Similar in growth to Sand Vetch but for spring planting only. Lb. 15c.

JERUSALEM ARTICHOKE. A well known vegetable produced from tubers like potatoes, which they resemble somewhat. Excellent food for stock. Do best in light rich soil, when an open exposure, but they will resist any degree of cold incident to the United States. Planted like potatoes and as early as the ground will permit in May. Can remain in ground all winter as freezing does not hurt them. Yield up to 500 bushels per acre. Lb. 10c.
Jerusalem Artichoke.

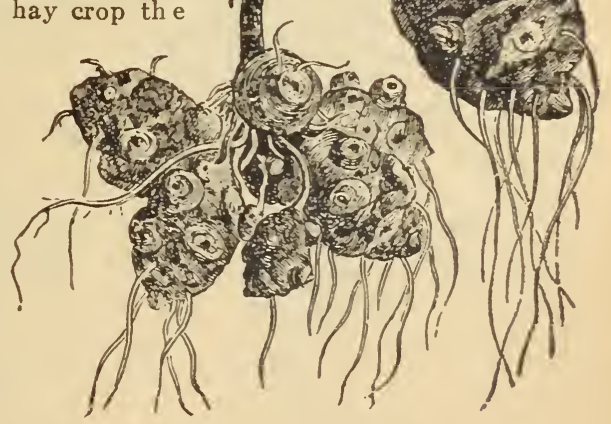


SUNFLOWER, MAMMOTH RUSSIAN. Single heads measure 15 to 20 inches in diameter, and contain an immense amount of seed, which is highly valued by all farmers and poultry breeders who have tried it as an excellent and cheap food for fowls. For poultry it is the best egg producing fruit known. It can be raised cheaper $r$ n corn, and is destined to be an article of great value. Every farmer should plant some of the seed in any waste piece of ground any time from early spring to the middle of July. Three pounds of seed will plant one acre. Lb. 15c.

\section{MISCELLANEOUS FIELD SEEDS}

SILVER HULLED BUCKWHEAT. An improved sort, much excelling the old common varjety which it has about usperseded with us. It blooms longer, matures sooner, and yields double the amount per acre. Husks thinner, corners less prominent and seeds of a beautiful light grey color. Flour made of this variety is pronounced better and more nutritious than others. Thirty to fifty pounds to an acre. Lb. 15c.

JAPANESE BUCKWHEAT. A new variety that has been raised here with good success. Early and very productive, with kernels twice the size of any other buckwheat, of a dark rich brown color and makes a superior flour. As it possesses a branching habit only half as much seed is required to plant an acre. Straw is very stiff and stands.well up. Lb. 15c.

CANARY SEED. As easily grown as wheat. Requires similar culture 20 to 30 pounds to an acre. $\mathrm{Lb} 30 \mathrm{c}$.

FLAX SEED. Largely grown in this state for seed. Sow one-half to three-quarters bushel to the acre. Can furnish choice, re-cleaned seed any time at market price.

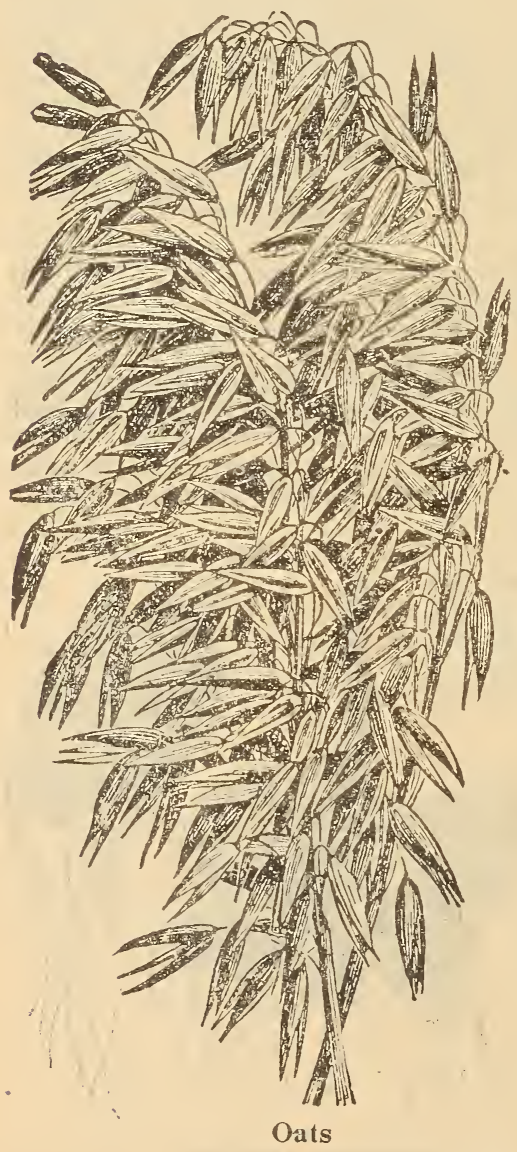

\section{GRAINS}

We give special attention to our grain, procuring them from reliable growers who select for seed. We then reclean the grain in our warehouses. We do not give prices in the catalog as these prices fluctuate with the market. Ask for market prices.

\section{BARLEY}

Sow 50 to 60 pounds per acre. It is an unquestionable fact that Texas produces Barley much brighter in color than countries having much rain.

CHAMPION BEARDLESS BARLEY. A new beardless barley, earliest barley known, about ten days earlier than other kinds. A good yielder, six-rowed and strictly beardless. It can be handled as easy as oats. This barley is not strictly pure and has a few bearded heads in it.

TEXAS WINTER BARLEY is the bes variety for the Southwest. Barley is often an excellent crop, not only for grain, but to furnish winter grazing for the horses, cattle and especially logs and poul try. It is strictly a winter barley and withstands the severe weather. It is recommended above all others for early and late fall planting. We call this variety "Texas Winter Barley" at the suggestion of Prof. H. B. Derr, Barlev Fixpert of the U. S. Department of Agriculture. It is quite similar to the famous Tennessee Winter Barley, but is more resistant to the cold than the later. Barley is a profitable and safe grain crop and highly desirable for winter grazing.

Ask for market prices.

\section{OATS}

Sow 50 to 65 pounds per acre. No crop gives better results by change of seeds than oats. If you have been re-seeding the same strain for several years now is the time to change. Do not compare our select, re-cleaned strains with the common oats frequently offered as seed oats.

RED RUST PROOF. Largely grown in this state. It is a heavy yielder and sure cropper and entirely rust proof, makes a very heavy grain. The stock in this variety is Texas grown from stock obtained from Texas, which will, we are sure, prove satisfactory. 


\section{GRAINS-(Continued $)$}

TEXAS GROWN HASTINGS 100 BUSHEL OATS. For an all-round general purpose oat you will find nothing that can compare with it. Planted in the fall it is almost as hardy as rye, stools out strongly, makes the best of winter and early spring grazing for cattle hogs, horses and mules. It's a true strain of southern oat, "rust-proof" to a remarkable degree and adapted to the South. Grains are exceptionally large and heavy usualy weighing 40 pounds or over to a measured bushel. It's just the oat for you, a southern thoroughbred, an oat that you can depend upon. No watter where you live in the South it's the right oat for fall planting.

FULGHUM OATS. This new variety is becoming very popular on account of its ability to stand cold, depth of root system, freedom from beard, sturdy upright habit, and being two weeks earlier than any other variety of oats. We recommend them for fall planting. Ask for market prices.

GENUINE HARDY WINTER EMMER. Black Seed. There is no grain crop that has received such flattering reports from the I'nited States Department of Agriculture as Winter Emmer. Seed is sown about the same time as winter wheat and the soil should be prepared in the same way. Emmer will stand more dry weather than oats will, and will also outyield oats. Seed that we offer yielded 50 bushels per acre. In feeding experiments Emmer has been found to be better inan barley or oats. Will also inake an abundance of fine pasture. The plants are very hardy and produce rather coarse leaves that are resistent to the most severe drouth. It is therefor a crop that is well adapted to the general conditions of Oklahoma, Texas, Kansas and Mexico. It requires about 50 to 60 poinds of seed to sow an acre.

MIRACLE WHEAT. This wheat, as the word indicates, is of most remarkable growth. There are instances where it made twicc as much wheat to the acre as other wheat sown on similar land and under similar conditions.

It is pure, soft, bearded wheat, and has been trich in Texas long enough to prove its excellent quality, and from the fact that it grows very rank on the ground, making good pasture, has a large, plump berry and does not shatter like Mediterranean, grows taller than other wheat. We believe it to be the best wheat for this country.

MEDITERRANEAN BLUE STEM BEARDED. We have secured sone very fine seed of this celebrated variety of wheat, which is so popular in Texas. Write for prices and samples in large quantities. All grain prices subject to market changes.

MACARONI WHEAT "KUBANKA" A Spring Wheat. A Wheat that will Grow where other varieties fail. The last threc seasons have brought to us many samples of Ilacaroni or Durum Wheat to be tested. We have followed the experiments very carefully and now we are convinced the variety "Kubanka" is the most satisfactory. The variety is no longer an experiment for yield or quality or grain. In fact we hear nothing but praise of its wonderful drouth resisting qualities and heary vield. The reports of yields are from $2 S$ bushels to 45 bushels per acre and many report such yields without irrigation.

Ask for market prices.

SPELTZ OR EMMER. A grain for dry lands introduced from Russia. This is a remarkable grain, and should receive the attention of all farmers. It is a species of drouth resisting Barley, and not inclined to rust. It will produce a fair crop under almost any condition of climate but grows best in dry prairie regions with hot summcrs, giving excellent results. Thrives on poor land in stony ground. The experiment stations of both Dakotas report that it resists drouth more than ca is or barley. All animals cat it greedily and are fond of the straw. It will undoubtedly become a regular valuable crop for stock feed. Sow 70 to $\$ 0$ pounds per acre very early. same as barley or oats. Our seed is Texas grown and acclimated.

Ask for market prices.

GENUINE TEXAS GROWN WINTER RYE. All ryc which we handle is strictly winter rye and perfectly hardy. It is Texas grown rye and adapted to this entire section, either for winter grazing or grain production. With half a chance it almost invariably "makes good" wherever planted in the South. Every bushel of rye that goes out from this house is right stock. We know exactly from where it comes. Every bushel of it goes though our recleaning machinery, which takes out all dust, trash and light grains that are left in the threshing machines. It's exactly what you need to make a successful rye crop next winter.

Prices of seed grain of all kinds are liable to change from time to time. Write for quantity prices when you are ready to buy. 


\section{GRAINS-(Continued)}

NEW ABRUZZI RYE. Twelve or fifteen years ago agents of the United States Department of Agriculture found a variety of rye in one of the Italian provinces and sent a quantity of it to Washington. From there it was distributed to various parts of the United States. In this way a prominent planter of South Carolina got hold of it. Its remarkably rapid growth so soon after planting attracted his attention and the small patch was carefully watched.

We have grown it for three years and do not hesitate to say that it is as far ahead of the Texas rye as the Texas is ahead of Northern rye; in spite of the extreme dry weather this spring it grew shoulder high and made a splendid crop.

The Abruzzi Rye stools out quicker and heavier than any rye we have ever seen and quickly covers the entire ground. It can be pastured a month to six weeks earlier than other varieties of rye or oats.

So far as we can learn it has succeeded equally well on stiff clay lands and the sandy lands of the Lower South.

For the dairyman this quickness of being ready to pasture will make it invaluable, and for all others it is certainly well worth while planting a variety that will make 50 to 100 per cent. more pasturage or hay in a season than the older sorts. We believe that the Abruzzi Rye will, in time, displace all other varieties of rye in the South, and you certainly ought to get a start of it this fall.

Pound, postpaid, 35 cents; 3 pounds, $\$ 1.00$.

\section{INSECTICIDES}

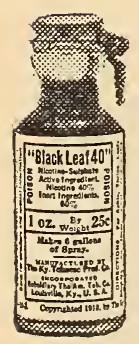

\section{"BLACK LEAF 40"}

"Black Leaf 40 " is a concentrated solution of Nicotine Sulphate, manufactured an guaranteed to contain not less than $40 \%$ of nicotine by weight. It is perfectly saluble incold water; does not clog the nozzle nor corrode the spray outfit; can be combined and applied with Lime-Sulphur, Bordeaux, Pyrox, Arsenate of Lead, Atomic Sulphur and such sprays. It is highly recommended by the state and government experts.

"Black Leaf $40 "$ is used as a safe and effective spray for plant lice(aphids), thrips leaf-hoppers and similar insect pests in the truck garden, orchard, flower garden, grove, park, vineyard, etc.

\section{REGARDING INSECTS}

Of the myriads of insects which attack plant life there are two distinct classes-the "chewing" (eating) kind and the sucking "“" kind. The "chewing" insects, such as beetles, caterpillars, etc. can be destroyed by spraying the foliage with a poison, such as Arsenate of Lead, which kills when it is eaten. On the other hand, "the sucking" feed by inserting their sharp slender beaks into the INTERIOR of the leaf, blossom, etc. They cannot eat plant tissue, and therefor cannot eat poisons. Hence must be destroyed with a preparation which kills by coming in contact with their bodies; in other words by a "contact" insectiside. The most common sucking insects, with soft bodies, are the aphids (plant lice),thrips and leaf-hoppers. They may be effectively controlled with "Black Leaf 40 " a concentrated sulotion of nicotine sulphate guaranteed to contain $40 \%$ of nicotine by weight.

$1 \mathrm{oz}$, sufficient to make 6 gal,

$1 / 2$ lb., sufficiènt to make 40 to 15 gal,

2 lb., sufficient to make 160 to 600 gal,

$10 \mathrm{lb}$., sufficient to make 800 to 3000 gal cannot be mailed.

\section{SOAP AS A SPREADER.}

In order to assist the "Black Leaf 40 " to penetrate to and thoroughly wet the insect, it is advisable when spraying with "Black Leaf 40 " alone to add 3 to 4 pounds of dissolved soap to every 100 gallons of spray. When using "Black Leaf 40 " in combination with other sprays, do not use soap

Price of soap lb. 15c. 


\section{INSECTICIDES}

IT STICKS. IT STAYS. IT STIMULATES. IT SAVES. WHAT?

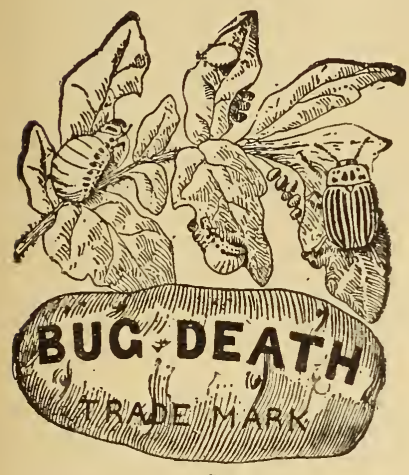

Reg. U. S. Pat. () FF.

Pat. March 16 and Nov. 9, 1897. WHY?

BUG DEATH. The Insecticide which kills most bugs and worms that eat the leaves of plants, trees, and vines; protects from injury by the flea beetle is especially valuable for potato, tomato, squash, and cucumber vines, currant and gooseberry bushes, strawberry plants, etc.; helps to ward off Blight, commonly known as Rust, on these vegetables and berries.

It saves beets from wormy leaves, celery from rust, asparagus from injury, cabbages and cauliflowers from destruction.

BUG DEATH is a fine powder which may safely be used on all plants, trees, and vines, as IT CONTAINS NO PARIS GREEN OR ARSENIC IN ANY FORM.

In careful tests with Irish potatoes those on which BUG DEATH was applied yielded 67 5-9 bushels more per acre than those treated with Paris Green. At an average price of $50 \mathrm{c}$ per bushel; this means more profiit for the planter.

Full directions for using, beth dry and in water, on each pakage. Give this preparation a trial, and be convinced of its merits.

IT STICKS. IT STAYS. KILLS BUGS. AND PAYS

Considering a proportionate increase of profit on other vegetables, can you afford not to use BUG DEATH? Price, $1 \mathrm{lb}$. sifter top carton, 20c. Ask for prices on large quantities.

To apply BUG DEATH in dry form use

THE DICKEY BUG DEATH

DUSTER

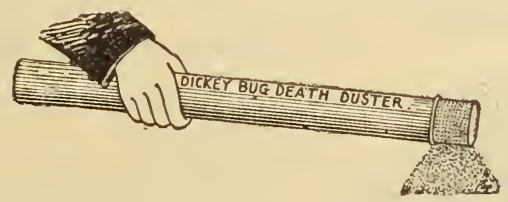

Excellent for small gardens. Puts the pow-

der just where you want it. Price 40c.

Postage $1 \mathrm{lb}$. parcel post extra.

\section{SLUG-SHOT}

SLUG SHOT. Hammond's Slug Shot. It kills potato bugs in all stages of growth, except in the eggs. It kills the black fleas on cabbages, turnips, beets, radishes, and egg plants. Apply by dusting over the plants. It kills the cabbage worm and also the currant and gooseberry worm, the aphis or green fly on roses and other flowers. Has prevented the ravages or the curculio and canker worm on fruit trees, has likewise been used around beans, melons, squashes, etc., with great success. Keeps the striped bug from all vine crops.

For Slugs on Roses Slug Shot is a sure killer. Apply with a bellows after a dew or rain, on both under and upper side of leaf. Price, not postpaid, $1 \mathrm{lb} .15 \mathrm{c} ; 2 \mathrm{lbs}$. 25c; $5 \mathrm{lbs}$. 50c;50 lbs. $4.50 ; 100$ lbs. $\$ 8.50$.

CONCENTRATED BORDEAUX MIXTURE PASTE. Too much credit cannot be given to the merits of Bordeaux Mixture. Use it all the time and on all occasions, where blight results from fungus or microscopic insects. It is a good tonic for all sick plants.

A half-pint of Concentrated Bordeaux Mixture Paste will make 31/4 gallons of Government strength Bordeaux Mixture by simply adding water. Price: $1 / 2$ pint 55c; pint $\$ 1.00$.

CUTWORM FOOD KILLS THE CUT WORMS. There is no more exasperating insect pest with which the gardener contends, than the cut worm.

Most pests attack the fruit, and can hardly spoil it all, or even spoil enough to make a failure of the crop; but the cut worm in about three bites kills the entire plant as effectively as tho it were consumed root and branch.

This is so easily avoided by using Cut Worm Food. One pound will protect 75 to 100 plants. Prices: 1 lb. pkg. 30c; Not mailable.

QUICK LOADER POWDER GUN used for powder insecticides. Small size 15c, postpaid. 


\section{INSECTICIDES-Continued}

FISH OIL SOAP. Very effective for washing trees and destroying all insects on the bark; it is also an exterminator of insects and lice on plants and shrubbery. Mix at the rate of one pound of soap to two quarts of water hot, and then add 5 gallons of cold water; apply with watering pot or syringe; used in this manner it will promptly rid cabbage or any other vegetable plants, also rose bushes and all sorts of fruit trees, of the aphides and other insects which so of ten injure them. Price, lb. 15c.

TOBACCO DUST. The best and most inexpensive insecticide and fertilizer of the day, and one of the most effective agents against the cabbage fly and worms which are so injurious and destructive to Cabbage and Cauliflower plants, and to Cucumbers and Melons. Used by the large cucumber growers with satisfactory results. We have had opportunity to have a thorough test of our Tobacco Dust on chicken lice, and have found it to be the best insecticide for henneries, under setting hens, etc. We have had it tested by a number of poultrymen, who pronounce it to be the best agent against poultry vermin. Also for insects on Flowering and Vegetable Plants; in fact, for all live plants. In addition to the advantageous results of the Tobacco Dust as an insecticide, it is one of the best fertilizers. It is good as a commercial fertilizer, used at the rate of 300 lbs. to the acre. lb. $10 \mathrm{c}$.

DRY ARSENATE OF LEAD. We unhesitatingly recommend Dry Arsenate of Lead as being the best means of ridding trees and plants of all leaf-eating insects, such as coddling mouth, potato beetle, cabbage worms, etc. Its superiority as a successful dry powdered arsenate of lead is unquestioned, and for all uses it is far superior in all points to any paste arsenate of lead upon the market. It mixes easily, less freight to pay, economical and always the same. One pound of Dry Arsenate of Lead will do the work of three pounds of paste and do it better. Cannot be mailed. lb. 35c.

PARIS GREEN. Mixed at the rate of one pound to two hundred gallons of water, it will prove effective against all chewing insects. Put up in 1 pound packages only at 75 cents per pound. This article is liable to fluctuate in price. Cannot be mailed.

LONDON PURPLE. Used for killing potato and other bugs. Price, lb. 50c.

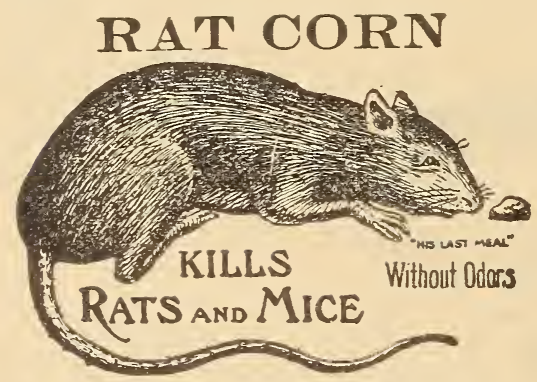

Before Eating Rat Corn.

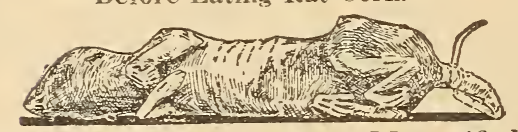

After eating Rat Corn he is Mummified

TREE TANGLEFOOT is a sticky compound similar to that used in making Tanglefoot Fly Paper and is especially adapted for protecting trees from the attack of climbing and creeping insects, particularly gypsy, browntail and tussock caterpillars, canker worms, climbing cut worms and ants. On matured fruit trees and all shade trees it is applied directly to trunks, but on young fruit trees we recommend application over strips of manila paper.

One pound makes 9 to 10 lineal feet of band. One application remains sticky 3 months and longer or 10 to 20 times as long as any other known substance. On account of this great superiority it has practically displaced all other banding compounds in the United States and in many foreign countries.

\section{RAT CORN}

Mice without Odor. Sold the World Over.

Rat Corn will exterminate rats, mice, moles and gophers from your premises in a safe, sane and sanitary manner. It mummifies them. No matter where they die they simply dry up. Positively do not leave any odor. Rat Corn is a new and scientific discovery and without a doubt the greatest destroyer of rats, mice and moles in the world. It is the only thing that kills rats and mice without any bad, dangerous or diagreeable effect. Rat Corn is put up in 25-cent size and 50-cent size.

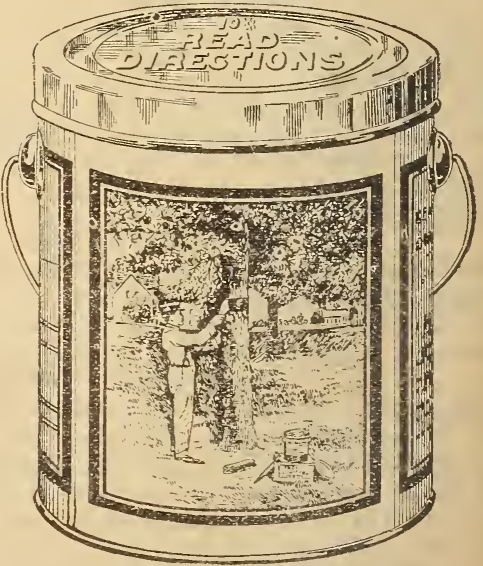

Tree Tanglefoot 


\section{TREE TANGLEFOOT (Continued)}

works alike in rain, sun, winds, etc. Does not soften, run or melt, yet is always elastic, expanding with growth of tree. No mixing required, simply open can and use. Applied with wooden paddle.

Will not injure trees.

For tree surgery, Tree Tanglefoot is superior to anything on the market. It is the best application after pruning or trimming-It will waterproof the crotch of a tree when nothing else will do it. For this purpose one application lasts several years, all the time wholly imprevious to air and water.

Guaranteed to keep perfectly many years in original packages.

Price: 3 -lb. pkg. $\$ 1.00$ each. Mailable.

\section{FERTILIZERS}

BONE MEAL One of the best lawn dressings. Decomposes rapidly, yet is a good fertilizer through the second season after using. Can be applied at any time, but is more effective if used in early spring. Produces a thick, luxurious turf. 2 Lb. 15c.

DRY BLOOD MEAL. Recommended where a highly nitrogenous fertilizer is required. Very quick-acting and permanent in its effect. $2 \mathrm{Lb} .15 \mathrm{c}$.

NITRATE OF SODA. A fertilizer very quick in action and used for the nitrogen it contains. Creates rapid growth, is odorless, very quickly and entirely soluble. Should be applied only whell plants are above ground. Great care should be exercised in its use as it is one of the strongest fetilizers known. Will mature a crop several weeks earlier and greatly improve it. Has been used with excellent results in Arizona. Lb. 10c; 3 lbs. 25c; 10 lbs. 75c; 25 lbs. \$1.50; 100 lbs. $\$ 5.50$.

GUANO. This is a highly nitrogenous fertilizer rich in plant food and an excellent material for increasing growth and a profusion of flowers and fruit. Lb. 5c.

LIME FOR DISINFECTING. $40 \mathrm{lb}$. bag 50c.

FERTILIZER LIME. $50 \mathrm{lb}$. bag 45c.

\section{ASK FOR PRICES ON LARGE QUANTITIES}

\section{BIRD SEED}

Our best mixed Bird Seed is put up according to the best formula for the health of birds, from the cleanest and choicest seeds. Special prices on larger lots.

MIXED BIRD SEED. Per lb. 30c. CANARY SEED. per lb. 30c. HEMP SEED. per lb. 15c. RAPE SEED, per lb. 25c. CUTTLEFISH BONE. Per oz. 5c; per lb. 75c. Parcel post extra.

PORCELAIN NEST EGGS. The "Opal" brand are the best. They are clean cut and uniform. Worth double the common ones. With these there is no danger of getting bad eggs mixed up with the fresh ones, nor of the hens acquiring the habit of egg eating. 3 for 10c; 6 for $15 \mathrm{c} ; 12$ for $30 \mathrm{c}$; if wanted by mail $40 \mathrm{c}$ per dozen.

MEDICATED NEST EGGS. Your hens cannot lay when infected with vermin. These eggs will give your hens relief from Lice and mites and will increase your profits. These eggs will not glaze or slack when wet. Price 5c each; 50c per doz., postpaid.

\section{USEFUL BOOKS FOR THE PRIVATE OR COMMERCIAL GARDENER}

We carry in stock the following books on gardening, etc., which we will furinsh postpaid to any address on receipt of price.

Practical Suggestions on Vegetable Culture. Price 25c.

Colburn's Book on Alfalfa. By. F. D. Coburn. Price 50c. $\$ 2.00$.

Coburn's Large Book on Alfalfa. Price

How to Grow Mushrooms. Price 10c. 10c.

Helpful Hints to Broom Corn Growers.

Broom Corn and Brooms. 25c.

Sweet Peas, Up-to-Date. 10c.
Celery for Profit. Illustrated. By Grenier. Price 50c.

How to Grow Asparagus. By Hexamer. Price 50c.

Lupton's How to Grow Cabbage and Cauliflower for Profit. Price 30c.

New Rhubarb Culture. Price 50c.

Onion Culture. Price 50c.

Onions ior Prott. Price 25c. 


\section{LOWELL SPRAYERS,}

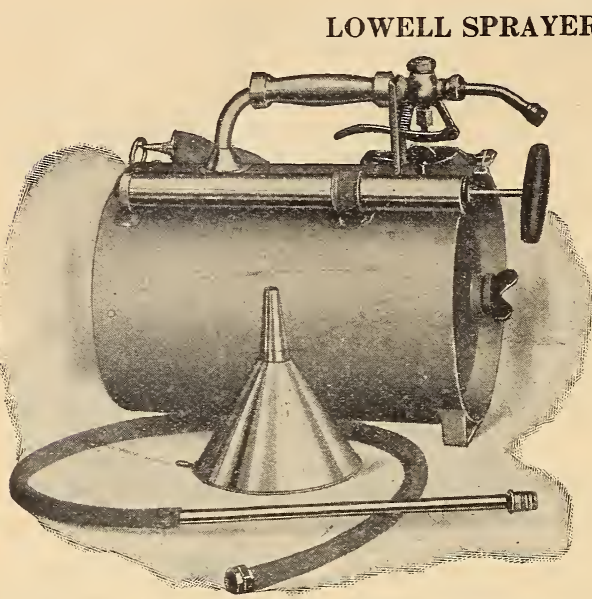

Lowell Fountain Compressed Air Sprayer No. 110. Galvanized Steel aluminized.

No. 111. Brass, polished and lacquered.

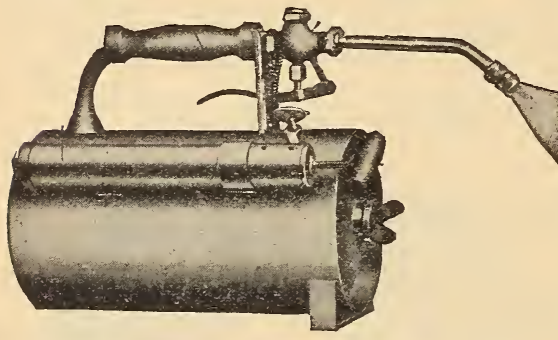

Lowell Baby Fountain Compressed Air Sprayer

No. 120. Galvanized Steel, aluminized.

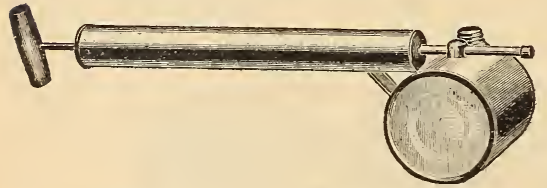

Lowell Continuous Sprayer No.115. All Tin. No.117. All Brass.

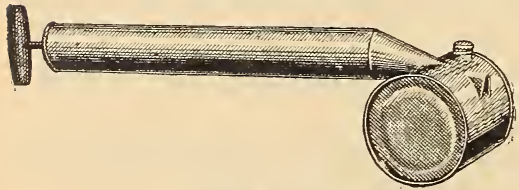

Lowell Ideal Sprayer.

No. 125. All Tin.

LOWELL IDEAL SPRAYER. The best low-prices tin sprayer on the market. It
LOWELL FOUNTAIN COMPRESSED AIR SPRAYER. The Lowell Fountain Compressed Air Sprayer is well adapted for the fruit grove, farmer, stockman, poultryman, florist, and for use of general disinfectants. It is the strongest small tank sprayer ever made, being constructed of heavy sheet brass or galvanized steel.

No other sprayer made will stand onehalf the pressure. Every sprayer when completely assembled is tested by air to 60 pounds to the square inch, while the pressure in service never exceeds 35 pounds no safety valve or indicator is needed with the Lowell Fountain Sprayer. Holds three gallons.

Price: No. 110. Galvanized Steel aluminized. $\$ 6.50$.

No. 111. Brass, polished and lacquered. $\$ 9.00$

LOWELL BABY FOUNTAIN COMPRESSED AIR SPRAYER. Owing to a demand for the Lowell Fountain Compressed Air Sprayer in a small size of domestic purposes and inside work, this sprayer is made in a gallon capacity size, along the same lines exactly as our regular three gallon Compressed Air Sprayer. It is equipped the same with the exception of the hose attachment for tree work, which would not be practical for this size sprayer. On account of its size shoulder strap is also unnecessary.

It is equipped with a long spray crook which can be adjusted to spray in any direction; this feature combined with its size makes it very useful for domestic and disinfectaing purposes. Capacity of Tank one gallon.

Price: No. 120. Galvanized Steel, Aluminum Finish $\$ 4.50$.

LOWELL CONTINUOUS SPRAYER. The best small sprayer made. Will handle all insecticides and disinfectants, and operating on both strokes of the plunger, it throws a continuous spray. Two spray caps, one straight and the other at an angle, for spraying under leaves.

Price: No. 115. All tin. 80 cents.

No. 117. All Brass. \$1.10.

throws a spray as fine as steam and is very useful for applying liquid lice killer in cracks and crevices about the poultry house, roosts, nest boxes, etc.; also about the hog pens. It is more economical of the insecticide than a paint brush or other means of application. For applying insecticides on rose bushes, shrubs, etc., it is unequalled and should be in the hands of every gardener, poultrykeeper and fruit grower. Capacity one quart.

Price: No. 125. All tin, 55 cents. 


\section{LOWELL BUCKET PUMP}

The Lowell Bucket Pump is one of the latest inventions in a long list of successful spraying machines. We believe it is the best machine of its lind on the market.

The working parts are all brass, including cylinder, plunger tube, valves valve seats and cages.

The punger tube and handle are hollow, thus affording sufflcient air chamber to give a continuous spray. The cylinder and plunger tube are made of seamless brass tubing; the handle of malleable iron.

The foot rest is made of malleable iron, fastened to the cylinder with a clamp. It can be easily adjusted to fit any height pail or bucket without the use of a wrench.

It is equipped with three feet of $3 / 8$ inch hose, fitted with our own special spray nozzle. Hose is attached to pump with coupling. The nozzle threads are all standard, thus enabling one to use any make of nozzle desired.

This pump fitted with our special type plunger gives all the best features of a bucket sprayer combined in a moderate priced machine.

Price: No. 109 Lowell Bucket Pump \$4.00.
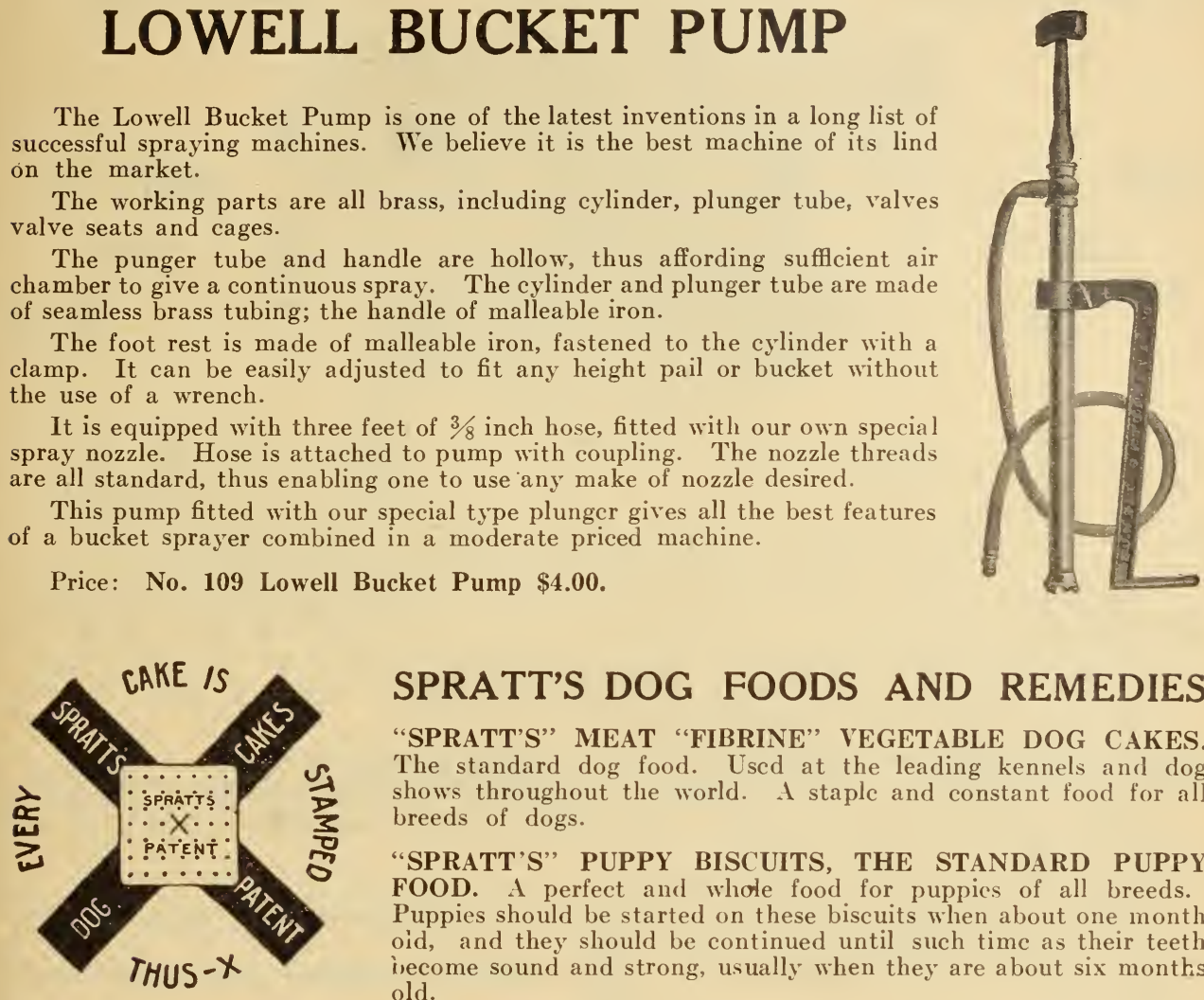

SPRATT'S DOG FOODS AND REMEDIES “SPRATT'S” MEAT “FIBRINE” VEGETABLE DOG CAKES. The standard dog food. Uscd at the leading kennels and dog shows throughout the world. A staple and constant food for all breeds of dogs.

"SPRATT'S" PUPPY BISCUITS, THE STANDARD PUPPY FOOD. A perfect and whole food for puppies of all breeds. Puppies should be started on these biscuits when about one month oid, and they should be continued until such time as their teeth isecome sound and strong, usually when they are about six months old.

SPRATT'S TONIC AND CONDITION TABLETS. To build up after sickness and to put in bench show form, etc. _...

SPRATT S WORM CAPSULES. An expellent of Round, Maw and Tape Worms _...-

SPRATT S WORM CAPSULES FOR PUPPIES. May be given with perfect safety to puppies from six weeks old to six months.

SPRATTS PARROT FOOD. A mixed food for Parrots which should be kept before them all the time. Price in cartons, 15c each.

SPRATT'S PATENT POLLYCRACKERS. A specially prepared bicsuit for Parrots and all similar birds. Made in a convenient size for a bird to grasp. It is greatly relished as a change Price, lb. 20c.

SPRATT'S BIRD TONIC. (Henning s). For the prevention and cure of all diseases which cage birds are subject to. Price, in bottles, 25c.

SPRATT'S “DEFIANCE” MOCKING BIRD FOOD. The purest food obtainable for Mocking Birds, Robins, Thrushes, and other soft-billed birds. Price in tins, 60c.

"HENNING S" GENUINE FISH FOOD. Prepared in wafer form for convenience in handling. Price, Cartons, 15c; by mail, 17c. 


\section{BUCKEYE INCUBATORS}

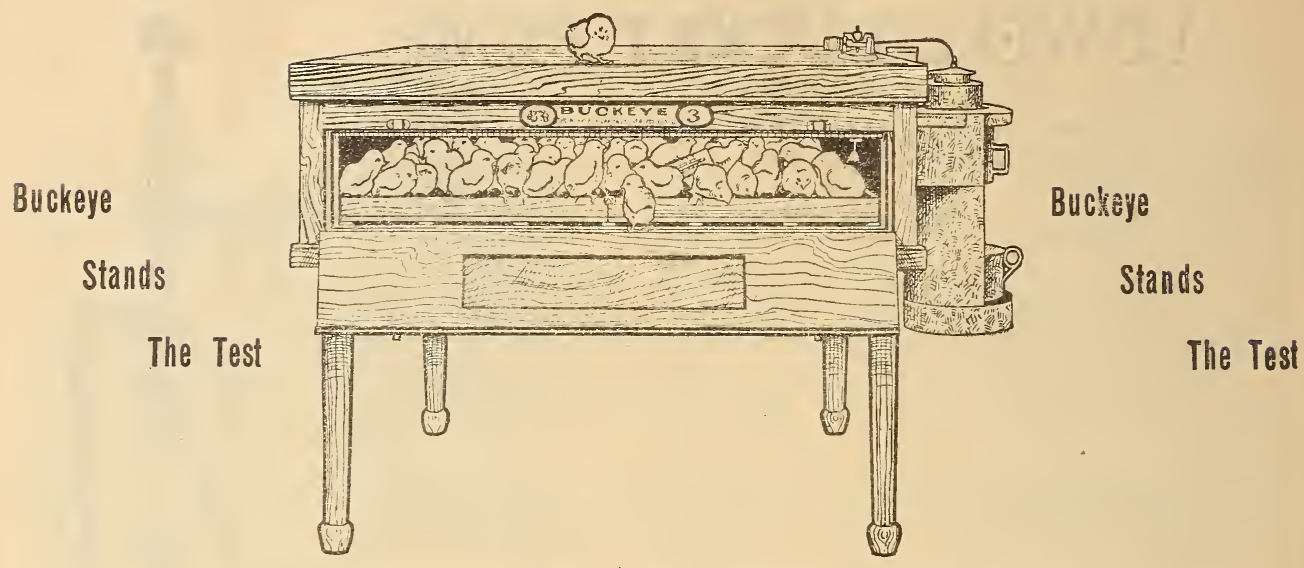

A Genuine Buckeye. With all the Desirable Buckeye Features

Maybe you don't own an incubator because you have always thought of them as mysterious and complicated machines.

Well, some incubators are, but-

The BUCKEYE is so simple that a boy or girl can operate it.

That's the secret of its wonderful success.

There are just three essential feature to the successful hatching of eggs-

Correct temperature, proper ventilation, and a certain amount of moisture.

Unless each of these three essentials is absolutely correct, the incubator must fail to a greater or lesser degree.

The correct temperature is 103 degrees.

If any of the eggs in a BUCKEYE incubator were kept at any other temperature they wouldn't hatch.

BUT THEY DO HATCH, and that proves that every egg is kept in the exact, correct temperature.

You can place a dozen thermometers in a dozen different places in a BUCKEYE, and you will find them all alike.

We know of manufacturers who have spent a lifetime trying to build an incubator that would do that and THEY HAVEN'T SUCCEEDED YET.

Yet, it's easy with the "Buckeye Circulating Hot Water System."

You probably know that it is much easier to maintain an even temperature in a building that is heated by hot water, than if it were heated by hot air or steam.

Well, hot water is much the best thing to use for heating incubators, too.

Price of Buckeye Incubators:

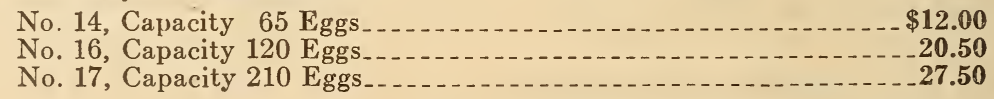

BUCKEYE STANDARD

No. 60, Capacity 60 Eggs____.

No. 1, Capacity 110 Eggs

No. 2, Capacity 175 Eggs_._._.

No. 3, Capacity 250 Eggs.

No. 4, Capacity 350 Eggs_...

No. 5, Capacity 600 Eggs

Approved by the National Board of Insurance Underwriters.

"BUCKEYE" means the "BEST." Anybody can Hatch Chickens with A "BUCKEYE." 


\section{"SECURITY" PORTABLE BROODER}

The Oil Burner that Broods like a Coal Burner

\section{THEY HOVER}

\T THE

CURTAIN

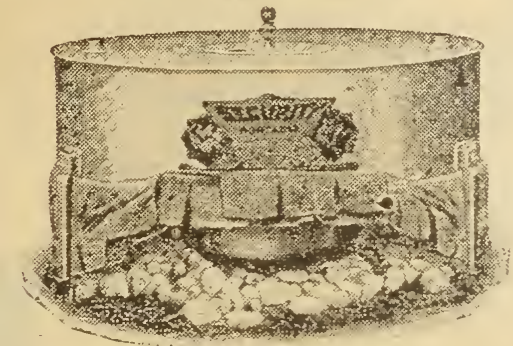

MAKES

CROWDING

IMPOSSIBLC

The SECURITY PORTABLE BROODER is all that the name implies-and more . It is the only lamp heated broorler ever invented that posseses EVERY DESIRABLE QUALIFICATION for the welfare of the little chicks.

It is the only oil burning brooder that provides EVERY IDEAL CONDITION which you know to be necressary to the health and growth of the rhicks, and its construction is so simple that the operator cannot go wrong. There is nothing to adjust, nothing to get out of order nothing to look after but the lamp and that requires filling but once in 24 hours.

It is a combination "Security" and "Simplicity" which insures those "just right" conditions that are so absolutely essential to the health and growth of the baby chicks. (Capacity 100 to 150 chicks. Shipping weight 160 pounds. Price $\$ 15.00$.

\section{THE STANDARD COLONY BROODER}

(Patented July 4, 1916.)

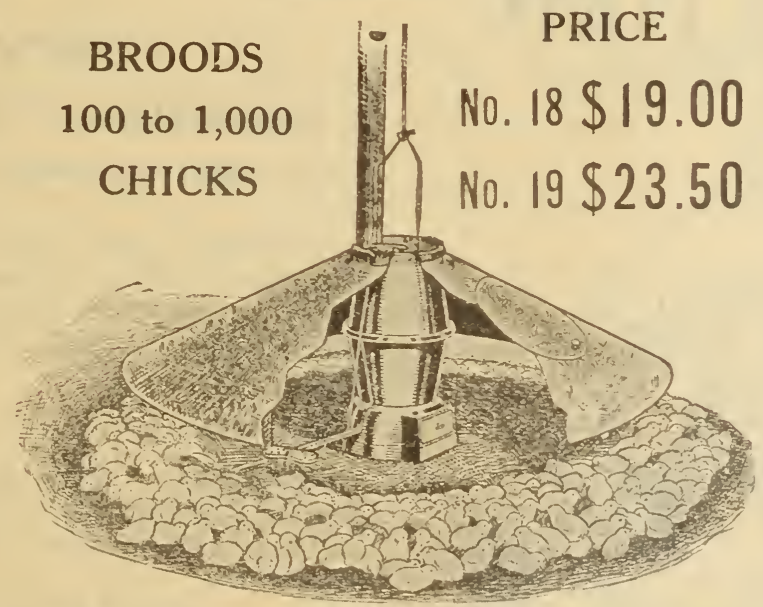

Showing a Standard Colony Brooder in Operation with 1050 Chicks

Self-Feeding. Self-Regulating. Hinple. Safe, Everlasting

Guaranteed Operating Cost Less than Six Cents a Day

\section{SAVES LABOR, TIME AND MONEY}

Sold on 30 Days Approval and You Write Your Own IONEY-BACK GLARANTEE. 


\section{PORTABLE BROODERS}

\section{The Greatest Oil-Burning Brooders \\ Ever Invented}

\section{AN ABSOLUTELY SATISFACTORY BROODING DEVICE}

\section{FOR THE BREEDER WITH SMALL FLOCKS.}

The Only Oil-Burning Brooder With ALL the Desirable

Features of the Modern Coal Burner

GUARANTEED to raise more chicks and gibger chicks than any oil-burning brooder on the market.

GUARANTEED to furnish an abundance of heat in any temperature down to freezing.

GUARANTEED to be absolutely free from any gasses and odors whatsoever, and to provide a circulation of pure, fresh air every minute in the day.

\section{SOLD ON 30 DAY'S APPROVAL \\ -and You Write Your Own- \\ MONEY-BACK GUARANTEE \\ THREE SIZES}

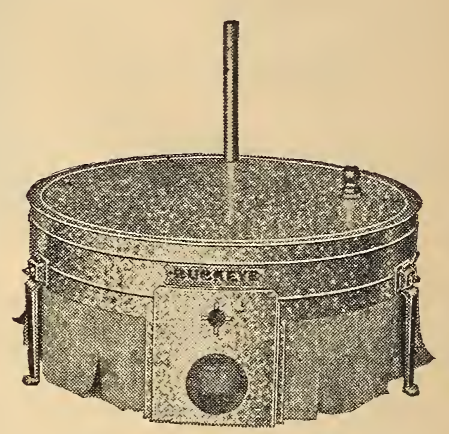

No. 20. Diameter 19 inches. Capacity 60 chicks. $\$ 8.50$.

No 21. Diameter 22 inches. Capacity 100 chicks. $\$ \mathbf{1 0 . 5 0}$.

No. 22. Diameter 30 inches. Capacity 150 chicks. $\$ 13.50$.

\section{POULTRY REMEDIES}

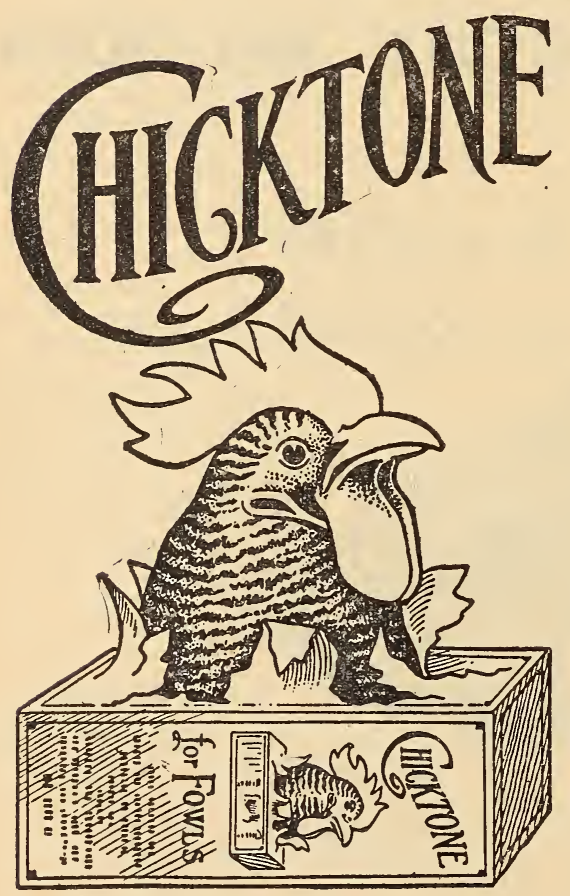

\section{TRY \\ CHICKTONE FOR FOWLS}

KING of all Poultry Remedies!

Chicktone is the only reliable preventive and remedy for Roup, Cholera, White Diarrhoea, Gapes, Limber Neck, Canker, Chicken Pox, Black Head and all other diseases common to Fowls.

For Chickens, Turkeys and Pigeons.

Protect your Poultry and save losses by keeping CHICKTONE on hand at all times. An ounce of Prevention is worth a Pound of Cure.

Chick tone is a Promoter of Health. Chicktone Means More Eggs.

Large 16-oz. bottle for 50c. Postpaid 60c

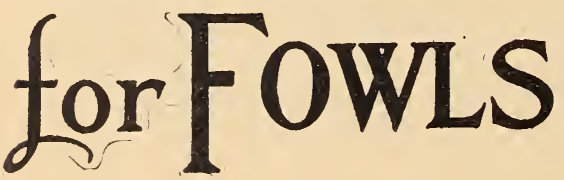




\section{POULTRY FOOD}

Healthy Chicks and Hens

Keep your chicks and hens healthy and full of vigor by giving them the right kind of food.

PURINA SCRATH FEED, Makes Hens Lay.

PURINA CHICKEN CHOWDER, Makes Hens Pay.

PURINA CHICK FEED, Saves Baby Chicks.

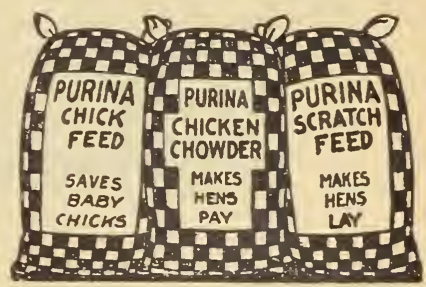

PURINA FOODS are prepared from the best quality of food stuffs obtainable, are compounded after formulas tested by long experience; and have proven successful in the hands of thousands of successful poultrymen. We feel that these foods will be equally successful in your hands, and sincerely hope that profit will follow your work.

Grain fluctuating, we quote on application.

FINE GROUND BLOOD MEAL. A highly concentrated and natural food for hens, containing 87 per cent. protein. Makes the plumage bright and glossy, and is particularly beneficial during the moulting season. Should never be fed without mixing with other food in proportion of 1 to 15 parts of meal or shorts. Price, $2 \mathrm{lbs} .15 \mathrm{c}$.

COARSE POULTRY BONE. Consists of ground beef bone thoroughly dried and free from grease. It is more economical and better in every way than raw beef bone. Rich in bone phosphate of lime, which is necessary for making egg shells, and for building up the frame of the chickens. Should be placed in liberal quantities in a clean dry place easily accessible to the chickens at all times. Price, 2 lbs. 15c.

FINE POULTRY BONE. Is the same as the coarse, but ground finer for the small chickens. and is a great frame builder. Price, 2 lbs. 15c.

BONE MEAL. Can be mixed with the mash in limited quantities. Price, $2 \mathrm{lbs}$. 15c.

MEAT SCRAPS. Made from cooked beef scraps, thoroughly dried and ground. Is especially useful for fattening poultry for the market. It is better and more economical than fresh beef scraps, because it is concentrated and free from moisture. A great flesh producer. Price, 2 lbs. 15c.

\section{ASK FOR PRICES ON LARGE QUANTITIES}

GENUINE CRUSHED OYSTER SHELLS. Every pound of oyster shells offered by us is dried by a patent, hot-air process, and not by direct fire, which burns out some of the most desirable qualities.

Our shells are crushed and ground to the size which expert poultrymen agree to be the best. If you have purchased other brands of Oyster Shells, you have noticed that there are 10 to 25 pounds of waste, consisting of dirt and dust, mixed in with every 100 pounds of shell. This means a loss to you. Every pound of shell we sell is all shell and no waste. It is needless for us to enlarge upon the value of crushed Oyster Shells for poultry. Every poultryman realizes their importance as an egg-shell maker and general promoter of good health. Coarse, lb. 5c;10 lbs. 25c; 100 lbs. \$1.25. Fine, lb. 5c; 10 lbs. 25c; 100 lbs. \$1.25.

MICA CRYSTAL GRIT. A First-Class Product in Extensive Use by Successful Poultryme n It is an established fact among poultrymen that, in order to make poultry raising a success, a first-class grit must be used. Ordinary water-washed smooth pebbles are not "grit." Soft, crushed limestone will not answer the purpose. Good poultry grit must have a formation which enabes it to retain its grinding qualities under the relaxation and contractions of the fowl's gizzard.

Mica Crystal Grit is as hard as flint, and in addition to its grinding properties, it contains lime in soluble form. This is highly valuable, as lime is a necessity for making egg shells.

The value of commercial grits sold for fowls varies fully as much as do the value of poultry foods. There are good grits for this important purpose and there are poor kinds. Some are coft and practically worthless.

The price of Mica Crystal Grit is low, quality considered. We depend for our profits on the large amount we sell and have made the price as low as grit of this quality can be sold for. We supply three sizes: No. 1 for brooder chicks; No. 2 for half-grown chicks and No. 3 for hens, turkeys, ducks and geese. No. 1 is used by many large duck breeders with satis-

factory results. Prices, lb. 5c. 10 lbs. 25c; 100 lbs. \$1.35.

CHARCOAL. Coarse, medium and fine. Lb. 10c; 3 lbs. 25c; 50 lbs. $\$ 2.00$. 


\section{PRATT'S POULTRY REMEDIES}
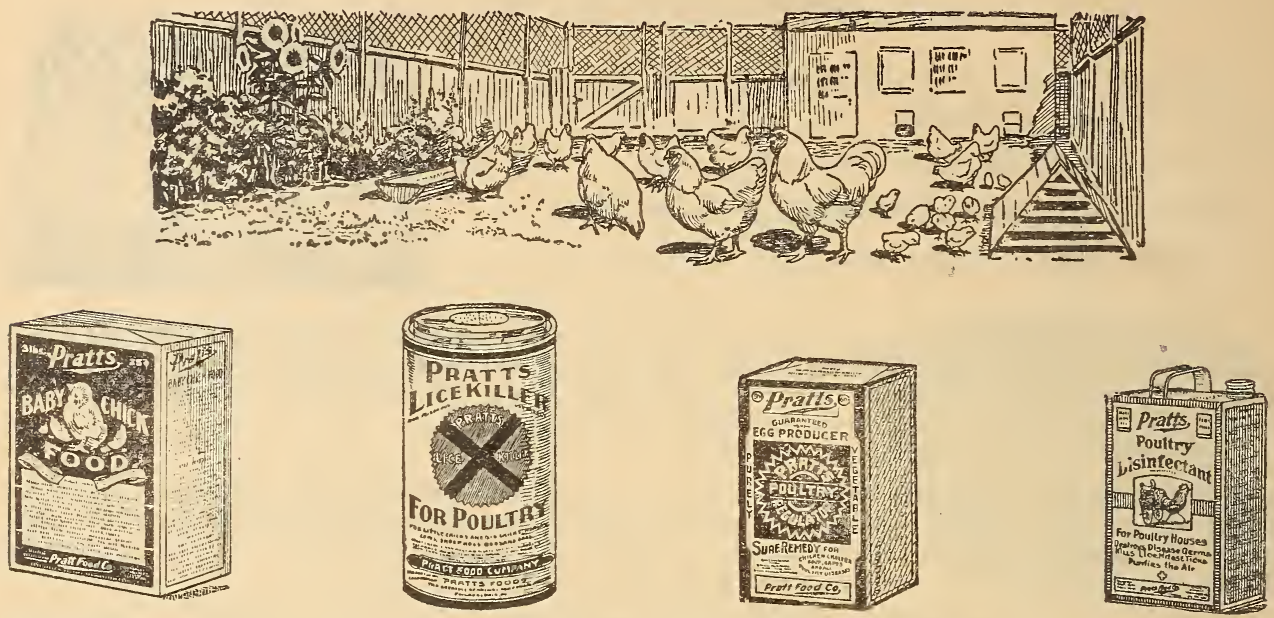

SATISFACTION OR YOUR MONEY BACK

Pratts Poultry Regulator. $25 \mathrm{lb}$. pail $\$ 2.50$; packages $\$ 1.00,50 \mathrm{c}, 25 \mathrm{c}$.

Pratt's Baby Chick Food. $14 \mathrm{lb}$. bags $\$ 1.00$; packages 50c and 25c.

Pratts Poultry Disinfectant. $\$ 1.00$ gal.; 35d. qt.

Pratts Powdered Lice Killer. 50c and 25c.

Pratts Condition Tablets. 50c and 25c.

Pratts Bronchitis Tablets. 50c and 25c.

Pratts Cholera Remedy. 50c and 25c.

Pratts Healing Ointment. 50c and 25c.

Pratts Colic Cure. $\$ 1.00$ and 50c.

Pratts White Diarrhoea Remedy. 50c and 25c.

Pratts Sore Head Chicken Pox Remedy. 50c and 25c.

Pratts Roup Remedy, Tablets or Powder. $\$ 1.00,50$ c and 25c.

\section{DR. LeGEAR'S STOCK AND POULTRY REMEDIES}

Roup Remedy, 25c per can

Sore Head Remedy, 25c per box.

Poultry Powder, 25c \& 50c per box; $\$ 2.50$ per 25- lb. pail.

Heave and Cough Remedy, 50c per box.

Colic Remedy, 50c per bottle

Stock Powders, 25c, 50c, \& $\$ 1.00$ per box
Cholera Remedy, 25c per can

Screw Worm Killer, 25c \& 50c per bottle

Lice Killer Powder, 25c per can

Worm Remedy, 50c per box

Antiseptic Healing Powder, 25c \& 50c per can

Gall Remedy, 25c \& 50c per box.

Dip and Disinfectant, 50c per qt. can; $\$ 1.25$ per gallon.

\section{CONKEY'S REMEDIES}

RoupRemedy

Cholera Remedy

All guaranteed to give satisfaction or money refunded.

Gape Remedy

Gape Remedy

Chickenpox Remedy

Limber Neck Remedy

$\begin{array}{llll}-30 \mathrm{c} & 60 \mathrm{c} & \text { Postpaid } & 35 \mathrm{c} \\ -30 \mathrm{c} & 60 \mathrm{c} & \text { Postpaid } & 35 \mathrm{c} \\ - & 60 \mathrm{c} & \text { Postpaid } & 65 \mathrm{c} \\ - & 60 \mathrm{c} & \text { Postpaid } & 65 \mathrm{c} \\ & 60 \mathrm{c} & \text { Postpaid } & 65 \mathrm{c} \\ & 60 & \text { Postpaid } & 65 \mathrm{c} \\ & 30 \mathrm{c} & \text { Postpaid } & 35 \mathrm{c} \\ & 50 \mathrm{c} & \text { Postpaid } & 55 \mathrm{c} \\ & 30 \mathrm{c} & \text { Postpaid } & 35 \mathrm{c} \\ - & 30 & \text { Postpaid } & 35 \mathrm{c} \\ - & 60 \mathrm{c} & \text { Postpaid } & 65 \mathrm{c} \\ - & 30 \mathrm{c} & \text { Postpaid } & 36 \mathrm{c} \\ - & 60 \mathrm{c} & \text { Postpaid } & 70 \mathrm{c} \\ - & 35 \mathrm{c} & \text { Postpaid } & 45 \mathrm{c} \\ - & 30 \mathrm{c} & \text { Postpaid } & 40 \mathrm{c} \\ - & 60 \mathrm{c} & \text { Postpaid } & 70 \mathrm{c} \\ - & 50 \mathrm{c} & \text { Postpaid } & 60 \mathrm{c}\end{array}$

$65 c$

Scaly Leg Remedy

White Diahrroea Remedy

Head Lice Remedy.

Lice Powder

Lice Powder

Laying Tonic

Laying Tonic

Noxicide

Stock Tonic

Stock Tonic

Fly Knocker

50c Postpaid 


\section{MARTIN'S Wonderful Blue Bug Killer}

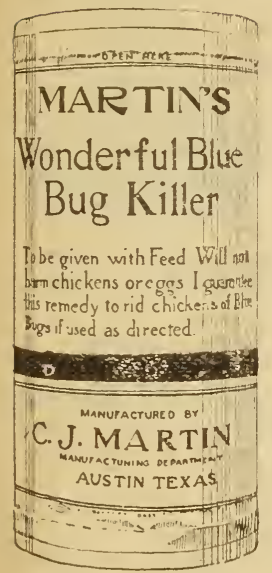

Kill the Blue Bugs and Stick Tight Fleas on your chickens by feeding Martin's Wonderful Blue Bug Killer. This remedy is guaranteed to rid your chickens of these bugs or your money back, if used as di rected. Will not harm chickens or eggs.

Directions-For every 12 chickens give one heaping tablespoon of Martin's Wonderful Blue Bug Killer mixed with one quart of wheat bran, then wet until crumbly, feed this once a day for one week. Price, 25c;50c and $\$ 1.00$ postpaid 30c; 60c and $\$ 1.10$.

\section{MARTIN'S SURE DEATH LICE POWDER. 15c; postpaid 20c.}

MARTIN'S SURE DEATH to all kinds of insects and germ life. Kills Bed Bugs, Roaches, Moths, Blue Bugs, Ints, Mosquito8, Fleas, Chiggers, Chicken Lice and all kinds of Vermin.

Disinfects Sinks, Outhouses, Closets, Basements, etc., etc. Small size 25c; qt. 50c; $1 / 2$ gal. 90c; gal. \$1.50. By express or freight.

\section{MARTIN'S Egg Producer and Poultry Regulator.}

('ontains the necessary drugs to help the hen lay eggs, and is also a fine regulator. It will build up your fowls and help prevent the breeding of diseases. Every chicken raiser who has baby chicks uses Martin s Egg Producer and Poultry Regulator, as it will help them digest their food and keep them in healthy condition. P'kg. 25 and $50 \mathrm{c}$. Postpaid, 30 and 60c.

\section{CRAWFORD'S Blue Bug Exter- minator.}

\section{CHOLERA AND LIMBERNECK CURE.}

Guaranteed to absolutely rid fowls of Blue Bugs, Lice, Fleas and other vermin or money. refunded. Blue Bug Exterminator is not a dope that you have to catch the fowls to apply, but a food that is fed with the other feed. And we positively guarantee that Blue Bugs, Lice or Fleas will not stay on fowls that are fed on this remedy. If little chicks are bothered with fleas, feed them 2 or 3 times with this food and the fleas will all drop off.

Blue Bug Exterminator prevents Cholera by keeping the bowels in a healthy condition.

For Limberneck, if the fowl is down and cannot eat, force the medicine down the throat until it reaches the crop.

Every owner of poultry should keep this remedy on hand, as the saving of one valuable fowl will buy several packages.

This is one of the greatest egg foods ever produced as it is a tonic and stimulant, it keeps fowls in perfect health which every one knows is essential to egg production. Price 25c and $40 \mathrm{c}$; postpaid $30 \mathrm{c}$ and $50 \mathrm{c}$. 

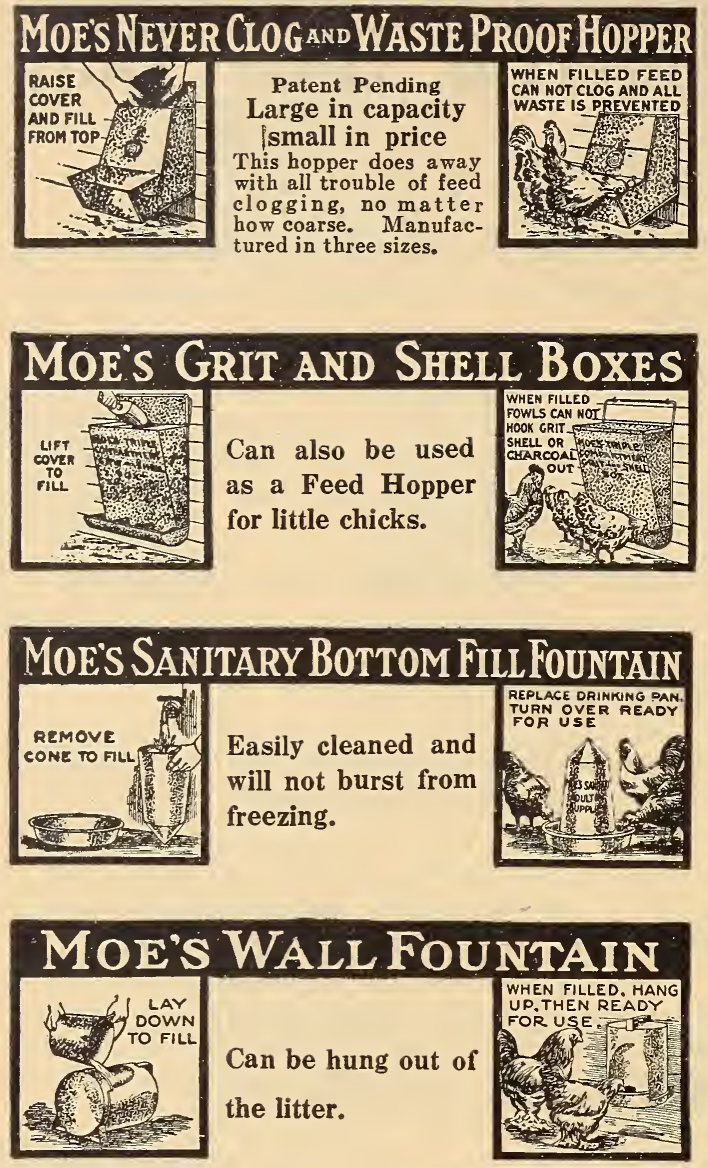

TMOE'S NEVER-CLOG WASTEPROOF HOPPER. Does away with all trouble of feed clogging, no matter how coarse. The gradual enlargement of the base, together with the vibration of fowls feeding from the trough forces the feed downward. Every safeguard has been placed in the con struction of the troughs to prevent the birds from throwing out the feed. 12 qt. capacity, 75c; 18 qt. $\$ 1.00$ each.

TMOE'S GRIT AND SHELL BOXES Grit, shell and charcoal has now become a recognized essential part of the diet, insurnig healthy fowls, and it cannot be more economically supplied than in one of these triple compartment boxes.

No. 45 , two compartments, $\$ 0.25$.

No. 9, Moe's Grit Box, capacity about $1 / 8$ bushel, 50c.

No. 90, four compartments 75 c.

TMOE'S SANITARY BOTTOM FILL FOUNTAIN. Made in two pieces. Made of the best grade of galvanized iron in three sizes.

No. 19 of about 1 qt. capacity, each 20c.

No. 20 of about 1/2-gal. capacity, each 25c. No. 24 of about 1 gallon capacity, each 35c.

MOE'S WALL FOUNTAIN. Very easy to fill. A strong substantia fountain at a low price. Made in three sizes.

No. 25 of about 1/2-gal. capacity 35 c. No. 26 of about 1-gal. capacity 50c. No. 27 of about 2-gal. capacity 75 c.

\section{LEG BAND FOR POULTRY}

SPIR-OL LEG BANDS are made in six colors and all sizes, and are put on and taken off like a key ring. Can't drop off. Colors are black, white, dark blue, red, yellow, green purple, light blue, garnet and pink. In ordering please state color wanted. Just the thing to mark the different pens. Handiest band to mark the pullets from the old hens.

Prices, postpaid: 12 bands for 15c; 25 bands for 30c; 50 bands for 50c; 100 bands for 75c; 500 bands for $\$ 3.60 ; 1000$ bands for $\$ 7.00$.

Chick, Bantam and Pigeon size Spirol Leg Bands as follows: 12 for 10c; 25 for 20c; 50 for 35 c; 100 for 50 c; 500 for $\$ 2.25 ; 1000$ for $\$ 4.00$. These bands come in the same colors as given above for poultry bands.

\section{PERFECTION ADJUSTABLE DOUBLE LOCK LEG BAND}

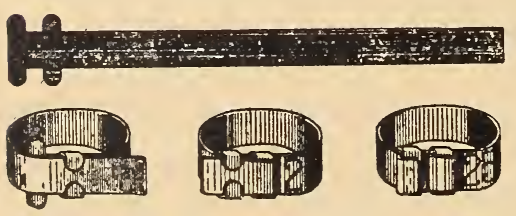

Patent Pending.
This Leg Band, when properly folded, forms a double lock that is positive in its grip and impossible to lose off.

It is made of aluminum, is adjustable and will fit all classes of fowl.

Price, postpaid: $12 \mathrm{c}$ for $15 ; 25$ for $25 \mathrm{c} ; 50$ for 40 c; 100 for $75 c ; 250$ for $\$ 1.75 ; 500$ for $\$ 3.00$ 


\section{THE OAKES ELECTRIC INCUBATOR}

If you have avoided taking up artificial incubation on account of the trouble, annoyance and uncertainty in running lamp-heated incubators, you need hesitate no longer, for all these object ionable features are eliminated in the Oakes elEctric Incubator.

Each one of our machines is thouroghly tested in every part before it leaves the factory and the regulator is adjusted to the proper temperature.

Pice: Oakes Electric Incubator with thermometer and cardboard egg tester.

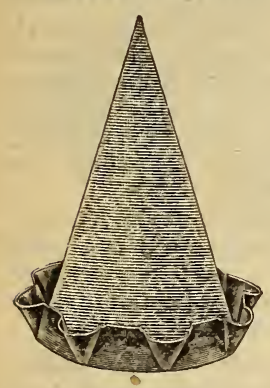

CHICK GRIT AND SHELL BOX.

Growing chicks should have grit, oyster shell and charcoal always before them; and for this purpose, our Chick Grit and Shell Box is indispensible.

It is made of galvanized steel with three compartments

Height, $7 \frac{1}{2}$ inches; width, 6 inches; depth, (front to back), 4 inches at bottom, and 2 inches at top.

Price (Shipping weight 2 lbs.) 35c.

Large size for grown fowls(Shipping weight 4 lbs.) $70 \mathrm{c}$.

\section{THE HANDY DRY MASH HOPPER}

The Handy Hopper is made considerably wider at the bottom than at the top, so that it is impossible for any sort of dry mash to clog in it. Feed put in this hopper cannot be wasted for the trough is deep, lias a wide flange around it, and solid partitions, making it impossible for the fowles to pile up the feed and throw it out with their bills.

We consider this one of the best hoppers made, and it is suitable for any kind of dry mash.

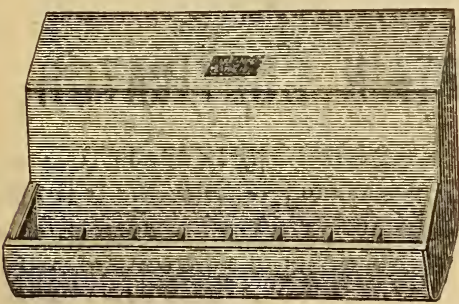

No. 1 Handy Hopper, 9 inches long, one compartment

Shipping weight in fibre cartoon 6 lbs.

No. 2 Handy Hopper, 15 inches long, one compartment,

Shipping weight in fibre carton, 9 lbs.

No. 3 Handy Hopper, 24 inches long, two compartments,

Shiping weight in fibre carton, 12 lbs. $\$ 2.50$

No, 4 Handy Hopper, 36 inches long, two compartments,

Shipping weight, crated, 17 lbs.

$\$ 3.25$

\section{DROP BOTTOM FOUNTAINS}

In this style of drinking fountain the pan which forms the trough from which the fowles deink is hinged at the back and fastened by a brass latch in front. The hood over the trough prevents falling dust and dirt from getting into the water; and when the bottom is turned back the inside of the fount can easily be cleaned out and kept in sanitary condition.

The hole which allows the water to run from the fountain into the trough is behind the brass latch, which prevents the water from slopping out when the fountain is handled.

The hinge is made with a brass rod to prevent rusting. Made of No. 28 galvanized steel in three sizes.

2-quart Drop Bottom Fountain

Shipping, weight, $21 \mathrm{lss}$

1-gallon Drop Bottom Fountain 1-gallon Drop Bottom Fountain Shipping weight, 3 lbs.

$\$ 0.90$

2-gallon Drop Bottom Fountain

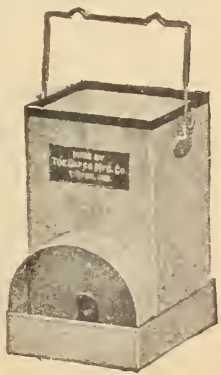

Shipping weght, $5 \mathrm{lbs}$. 


\section{CHICKEN LIFE SAVER}

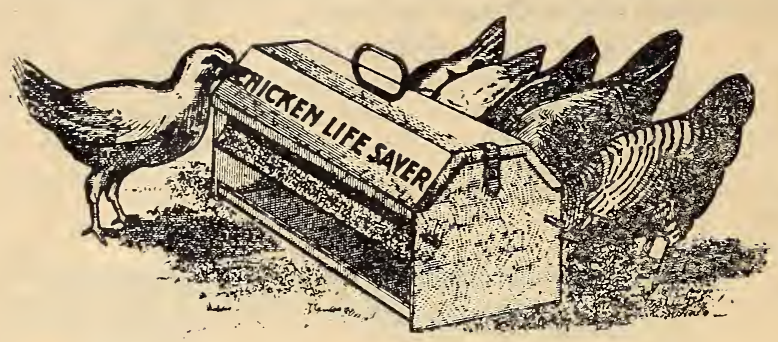

FREE YOUR CHICKS

From lice, mites, ticks and all other insects which infest them. Our Chicken Life Saver will do the work. It beats the old method of greasing by hand. - Try our method by which the chicken doctors itself.

The Chicken Life Saver consists of a galvanized iron box divided by a partition through the center with a feed and water tray on each side.

Above the traps are suspended, on swinging rods, absorbent brushes which are kept moistmed with oil fed from reservoirs directly above the brushes. As the chick eats or drinks its head wili neck comes in contact with the soft brush and is treated thoroughly with the specially prepared oil. With oil on its head the chick will soon apply it under its wings and other parts of the body. Our device is simple and durable and should last for many years. Our oil will cure any arse of Sore Head and kill all insects. Price \$2.00, with 50c can of Oil.

\section{CAHOON SEED SOWER}

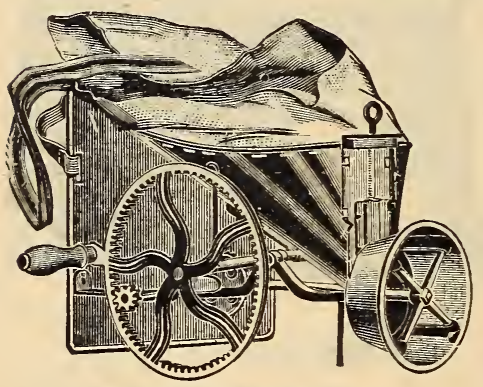

Cahoons Seed Sower.

For sowing alfalfa, wheat, oats, barley, rye, buckwheat, grass seeds, etc. The best machine of the kind on the market. The grain is held in a tight sheet-iron hopper, surrounded by a bag that will hold a bushel of seed. This is suspended by a strap from the operator's neck and held in position by a strap around the waist. The seed is thrown from eight to twenty feet on each side of the operator, the heaviest seed being, of course, thrown the greatest distance. Price $\$ 4.00$.

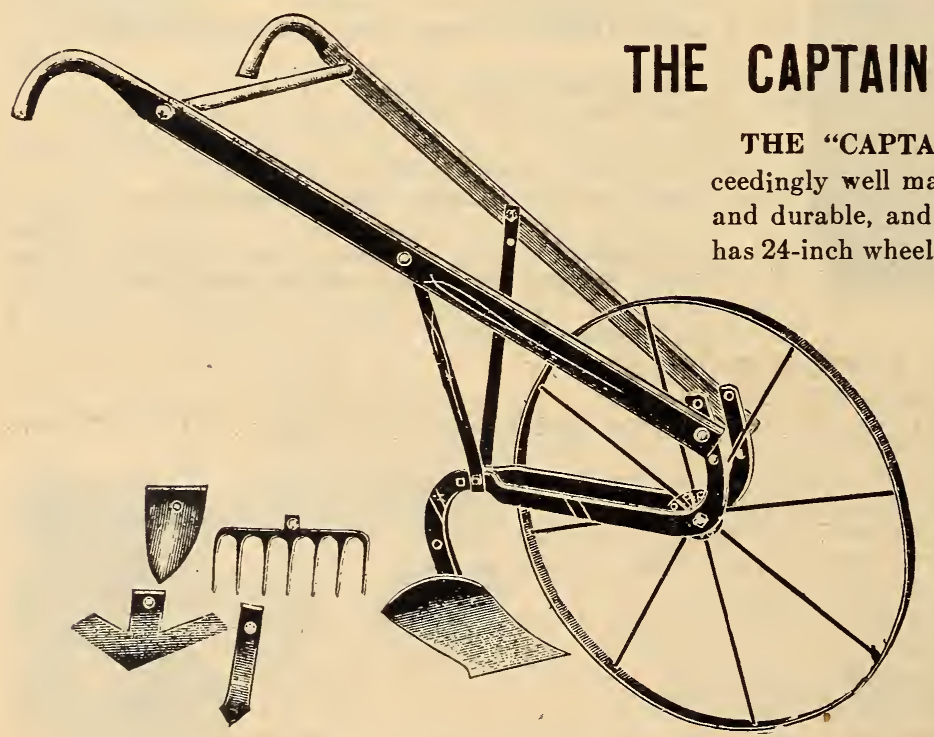

\section{CULTIVATOR}

THE "CAPTAIN" CULTIVATOR is exceedingly well made and finished. It is light and durable, and very easy to operate, as it has 24-inch wheel, and the handles are fastened to frame beyond the axle. Weight 22 pounds.

Complete, with four att a chments, each $\$ 5.00$. 


\section{Ship Eggs in the "DIAMOND"}

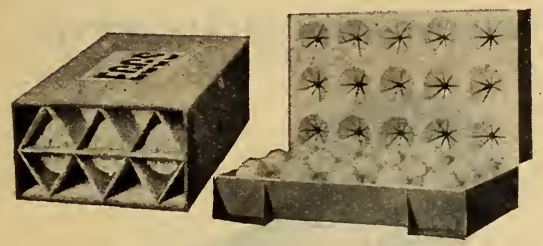

\section{FOR SAFE DELIVERY}

Diamond "Safe Delivery Parcel Post Egg Carriers" can be used repeatedly for a long time and each one will pay for itself many times in saving eggs from breakage.

\section{Price List}

\section{HATCHING SIZES}

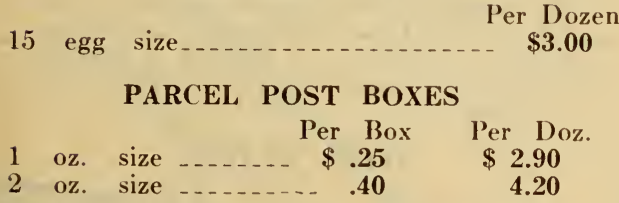

\section{PULL-EASY}

\section{AD JUSTABLE
2"TO 6"WIDE}

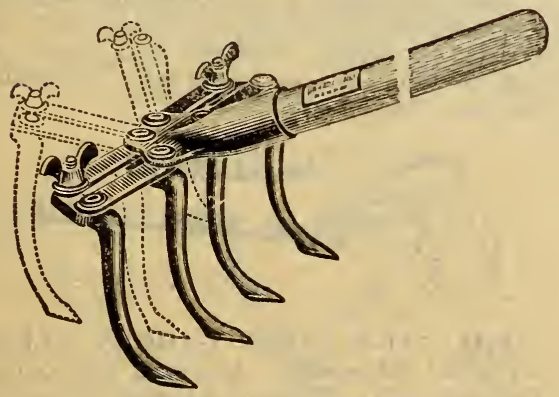

The picture above tells the whole story. The short handled Junior, our No. PEJ1, is for is for cultivating around bushes or creeping plants -and the long handled tool, our No. PEJ4, is for women and children to use in war gardens, flower beds and around bushes.

After the ground has been spaded, this handy cultivator prepares the soil, and is an efficient weeder and cultivator to use during the balance of the gardening season.

Price

PEJ-1. . . . . . Junior Cultivator

PEJ-4 _. _ . _ _ _. Junior Cultivator

PEC
A BROKEN EGG IS A WASTED EGG...

YOU WILL NOT HAVE TO PAY FOR ANY BROKEN EGGS IF YOU MAKE YOUR SHIPMENTS IN DIAMOND PARCEL POST EGG CARRIERS.

Postmasters, Express Agents, Producers and consumers have given the Diamond Parcel Post Egg Carrier every possible test and find it perfectly designed for the protection of eggs in transit.

\section{TAKE NO CHANCES \\ ON BREACKAGE}

Be sure of safe delivery. Protect yourself against loss of eggs and loss of profit. Ship eggs in the Diamond Parcel Post Egg Carrirer.

Selected eggs bring best price---shipped to the customer in Diamond Parcel Post Egg Carrier.

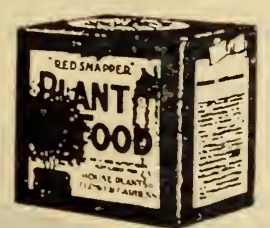

\section{"RED SNAPPER" PLANT FOOD}

\section{Makes Planrs Grow and Blossom}

This Plant Food which is for flowering plants, vines, shrubs, etc, has exceptional merits. We can speak from experience in this regard as we gave it tests in our own gardens and greenhouses this past summer. It certainly gives plants a quick yet sturdy, healthy growth The blossoms come out more profuse; they are larger in size and richer in coloring. This Plant Food is not the ordinary chemical stimulants generally offered for sale, but an organic fertilizer containing a very rich analysis of Plant Food. It is made from the head bones and nitrogenous cartilage of Red Snapper fish and is dried, sterilized and ground into the finest meal. It is thoroughly clean and sanitary and can be used in the finest homes and consrvatories as well as for out door use. We enclose in each box of Plant Food a small package of so-called Plant Tonic which is used to sweeten sour or dead soil and put it in better condition to assimilate the Plant Food. We wish every one of our customers would try one or more packages of this article and they will be surprised at the results.

\section{Price}

.7524 ozs. Plant Food with 4ozs. Tonic 50c,

1.504 lb. package with 8 ozs. Tonic $\$ 1.00$ 


\section{SMALL GARDEN IMPLEMENTS}

One of the best of this class, allowing use of the hand while working. Each 25c. postpaid.

\section{HAZELTINE WEEDER}

One of the best,

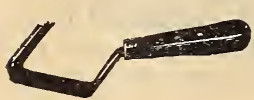
solid steel, good size and durable; in very general use over the country. Each 25c; postpaid 30c.

\section{EXCELSIOR WEEDER}

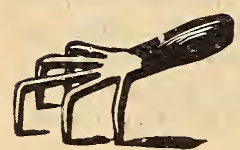

Avery useful tool for weeding seed beds, stirring the ground, etc. This is one of the most useful tools in working the garden. No one should be without it. Each 25c; postpaid 35c.

\section{Combining as it does}

\section{COMBINATION WEEDER}

both the rake and hoe, it is the most serviceable, desirable and perfect weeder on the market. Allows weeding close to the plants, and is offered at about the same price as the

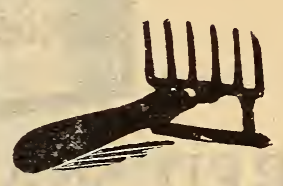
other weeders. Each 50c; postpaid 55c.

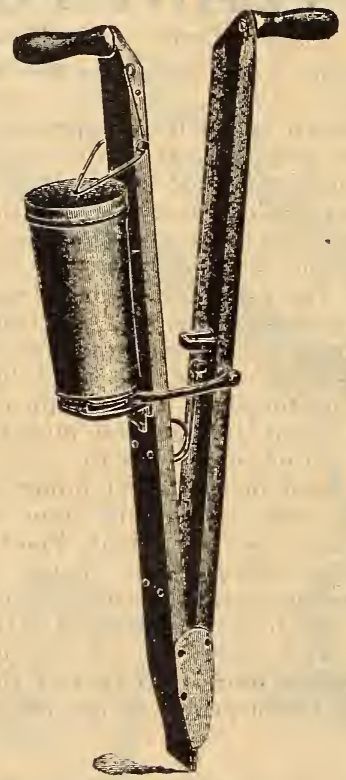

ECLIPSE HAND CORN PLANTER. All parts steel. Has four feed plates and is a sure dropper. Well made and finished Price $\$ 2.50$.

\section{HUMPHREY'S CONCAVE POTATO KNIFE}

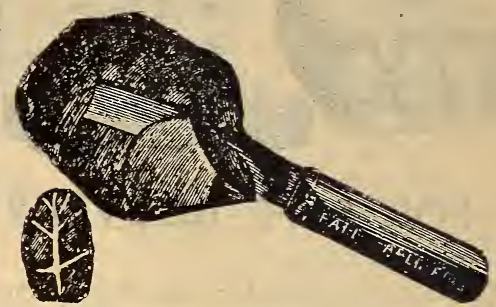

With the Concave Potato Knife, seed potatoes can be cut better, and $\$ 2$ to $\$ 3$ an acre saved in seed and time by its use. Our illustration shows how the eyes are cut with the kinfe, making a compact piece with the center surrounded by the greatest amount of tuber. If the same eye has been cut by a straight knife, the piece would be thin, flat and broad and liable to dry up and decay before germination. A circular is being put in each box with the knife. Price, postpaid, 30c.

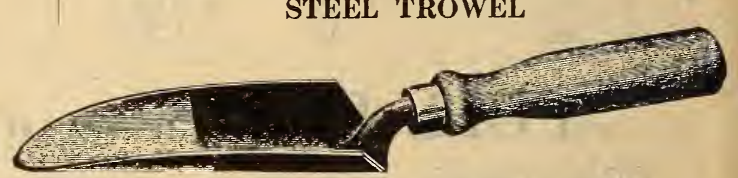

Ittis of one solid piece of steel and will outwear several of the ordinary sort. It is an article for which we have had many inquiries, filling a long felt want. Price 30c: postpaid 35c.

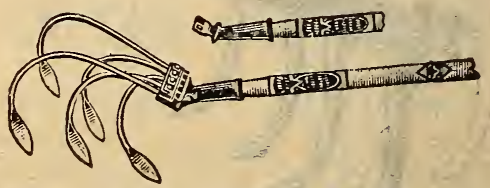

THE "NEW BOSS" GARDEN CULTIVATOR. Adjustable. Has only one casting and three bolts. Has 5 plows made of cruci ${ }^{2}$ le spring steel, oil tempered. Weight but three pounds. In planting and cultivating it takes the place of spade, hoe, rake and marker, and saves time and labor over all Price \$1.25.

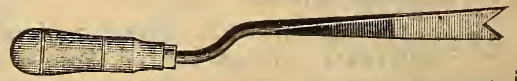

Asparagus Knife and Weed Digger.

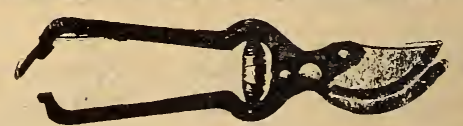

PRUNING SHEARS. No. 50. California pattern, polished tool steel blades, adjusting nut. Price $\$ 1.50$. 


\section{Planet Jr. Farm and Garden Tools}

We show in the following pages cuts of the best known machines of the Celebrated Planet, Jr., line.

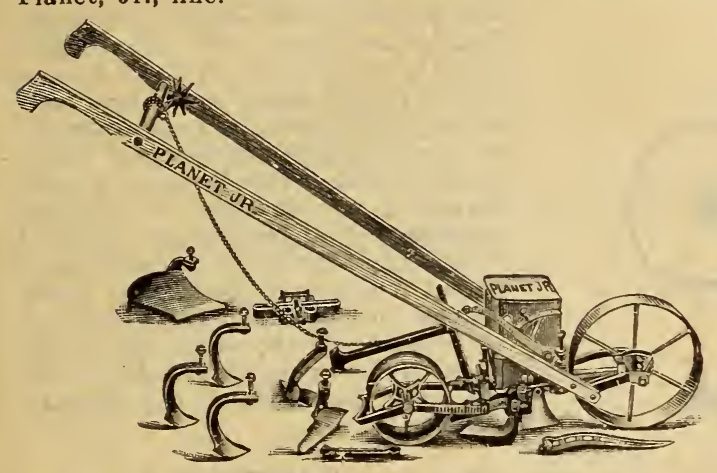

No. 4.-Planet, Jr.

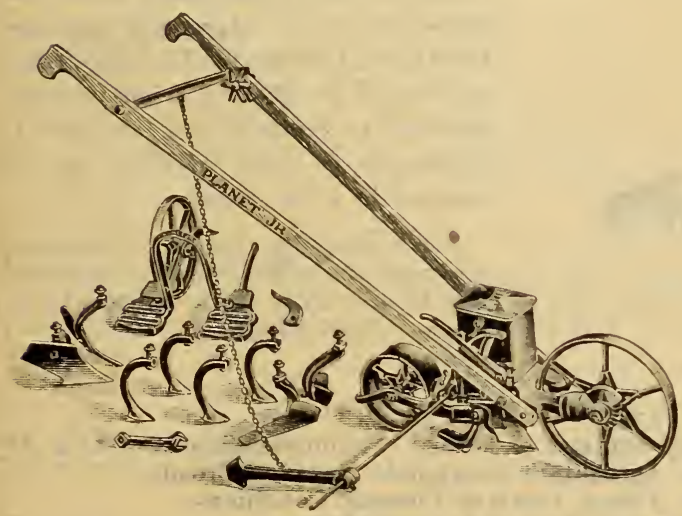

No. 25.-Planet, Jr.

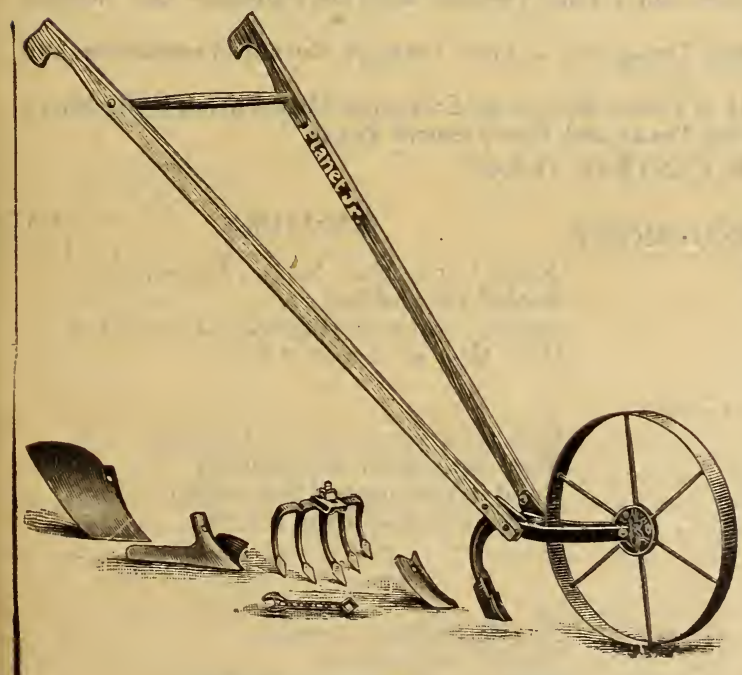

No. 4.-COMBINED HILL AND DRILL SEEDER, WHEEL HOE, CULTIVATOR AND PLOW.

The No. 4 Seeder is a great favorite; there are doubtless more of them in use in the world than any other seeder made. Gardeners and farmers having but a family garden who fear that they haven't quite enough work for a drill to do, will find this combined tool will quickly pay for itself in satisfaction, in labor-sa ving and in increasing crops. With it one can do almost all the hoeing and general work in the garden. Price Complete $\$ \mathbf{1 7 . 5 0}$ As a Seeder only $\$ 15.50$.

No. 25.-COMBINED HILL AND DRILL SEEDER AND DOUBLE WHEEL HOE, PLOW, ETC. As a drill it is almost identical with the "Planet, Jr." No. 4 Drill, will sow in hills and drills, $4,6,8,12$ or 24 inches apart, and the same automatic device for throwing out of gear, and the new combined cut-off and seed index with thumb screw adjustment. It is thoroughly substantial and accurate in sowing all kinds of seeds, either in hills or drills.

As a wheel hoe, it is identical with the "Planet Jr." No. 12 Double Wheel Hoe the very best machine on the market. The change from Drill to Wheel Hoe takes but a moment, and the entire combination is one we can heartily recoommend and guarantee to be satisfactory. Weight $38 \mathrm{lbs}$. Price a's shown in cut with all parts, $\$ 23.00$.

NO. 19 PLANIT JR. SINGLE WHEEL HOE, CULTIVATOR AND PLOW. This attractive implement is especially designed for the farmer's garden work, though ir offefs to every one with either field or garden a cheap and effective tool for wheelhoe operations. The high wheel makes easy running; the standard is slotted of depth regulation and an adjustable malleable piece carries any of the steels that go with the machine. The cultivating tooth does deep work and marks out row for onion sets, plants, etc. The sweep is finr foe level work by setting it flat; or by pitching the point downward, it is excellent for hilling for hilling crops in rows from 12 to 16 inches apart, or for opening furrows, for fertilizers, peas, beans, etc

No. 19 -Palniet, Jr. Catalog WRITE FOR PLANET, JR., CATALOG 


\section{PLANET JR. FARM AND GARDEN TOOLS (Continued)}

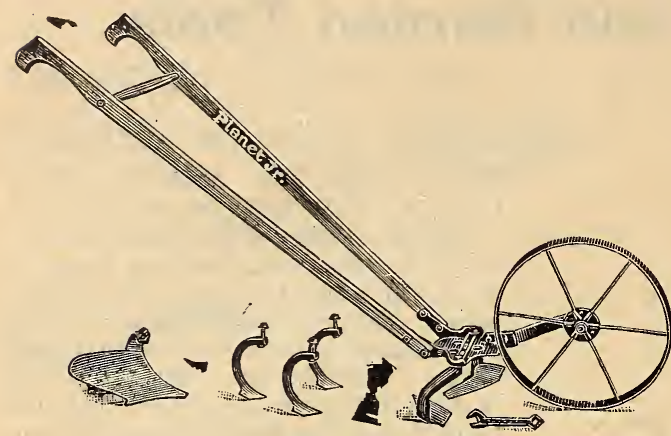

No. 17.-Planet, Jr.

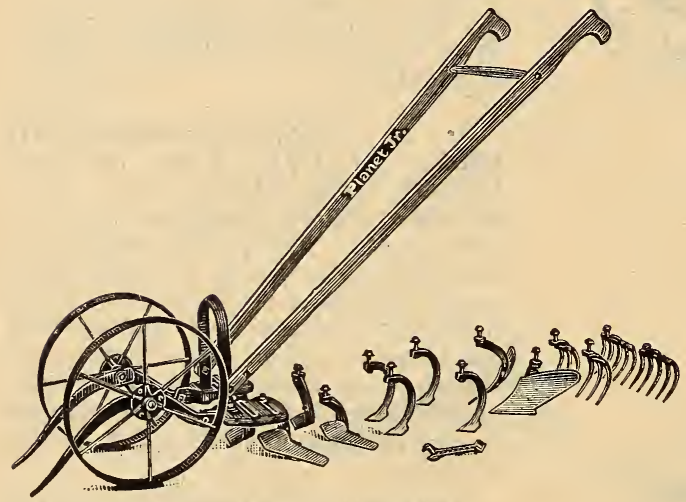

No. 11.-Planet. Jr.
No. 17.-SINGLE WHEEL HOE CULTIVATOR AND PLOW. This latest and best single wheel hoe has a very full set of tools, several of them being. of a new design, such as have been found to work in the very best manner It has 11-inch wheel with broad face, is very light, strong and easy running. It has adjustable handles and quickchange frame. The tools are a wellshaped plow for marking out, plowing, covering and late cultivation, a pair of 6 -inch shield hoes and three all steel patent cultivator teeth, the frame changes in height and the wheel may be attached to the other side of the wheel frame, when both sides of the row may be hoed at one passage. Price \$8.75.

No. 11.-PLANET, JR. is the best combined double and single wheel hoe made, and has the largest and most useful set of attachment'. The steel frame can be set at different heights to suit any kind or depth of work, and the attachments or their position can be changed in a few seconds.

The arch is high enough to straddle a row until plants are 20 inches high, and this insures close work and death to weeds. Price $\$ 16.00$.

\section{WHAT TO PLANT}

On the various kinds of soil and in the different climates of Texas. Recommendations of A. \&. M College, Department of Agriculture of Texas, Agriculture Committee Texas Railroads, .

The Divisions of Texas Given Below Follow General Climatic Conditions.

1. South Central Texas. Lies South of Austin and West of Colorado River.

2. East Texas. Lies East of Colorado River and a Line Through Bellville Palestine and Sulphur Springs.

3. East Central Texas. Lies Between East Texas and a Line Through Burnett Lampasses and Henrietta.

4. West and Northwest Texas. Lies West of Pecos River and Extended Line Through Big Sprin

5. West Central Texas. Lies between West Texas and East Central Texas.

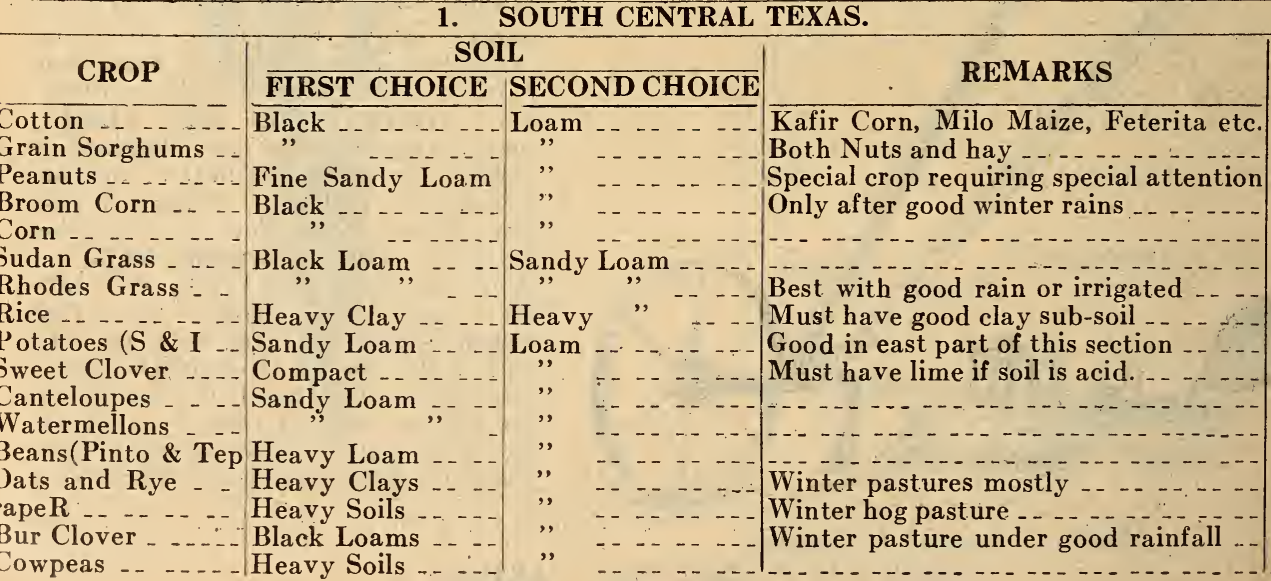




\section{EAST TEXAS.}

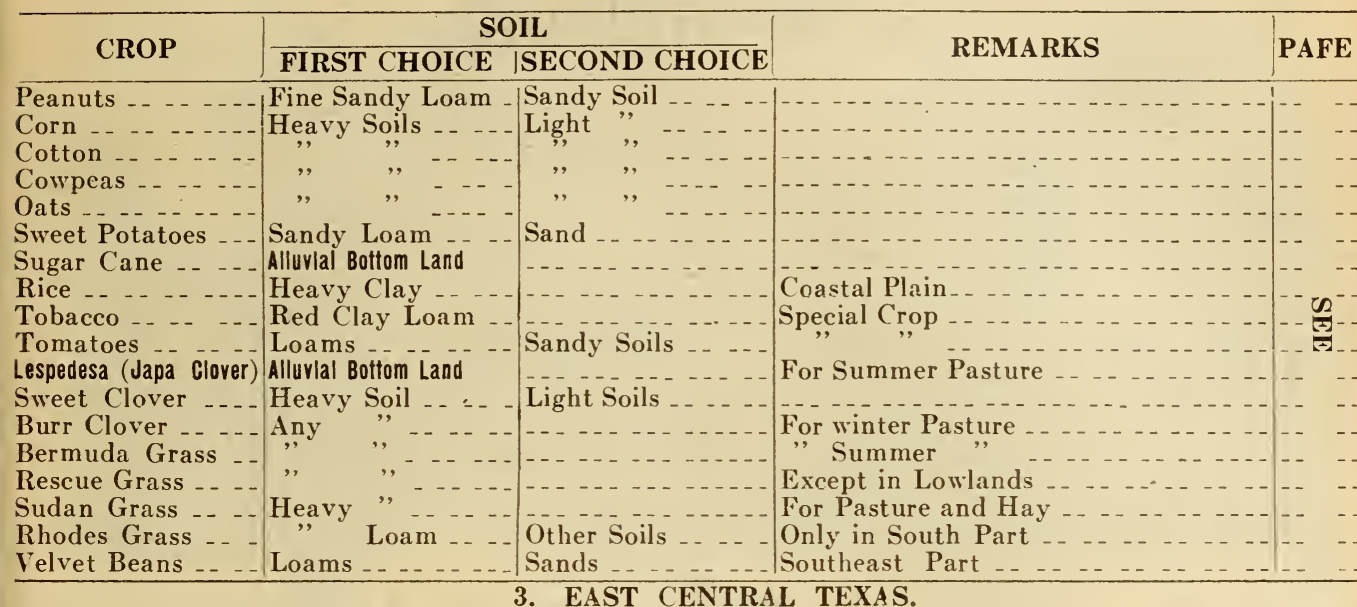

\begin{tabular}{|c|c|c|}
\hline otton & Black Clay _. . - & Loams \\
\hline Corn . & & \\
\hline Wheat and Oats & ", & ,, \\
\hline Barley and Rye - & ," & , , \\
\hline Silage Crops _- - & " " & \\
\hline $\begin{array}{l}\text { Peanuts } \\
\text { Grain Sorghums }\end{array}$ & $\begin{array}{l}\text { Loams }-\overline{-}^{-} \\
\text {Heavy Soils }\end{array}$ & $\begin{array}{l}\text { Sands --. } \\
\text { Loam Soi }\end{array}$ \\
\hline Cow Peas .. - . & & Sandy Soi \\
\hline $\begin{array}{l}\text { Pasture Crops } \\
\text { Hay Crops }\end{array}$ & $", \quad-\cdots$ & ,, \\
\hline & $m$ & \\
\hline
\end{tabular}

\section{WEST AND NORHTWEST TEXAS}

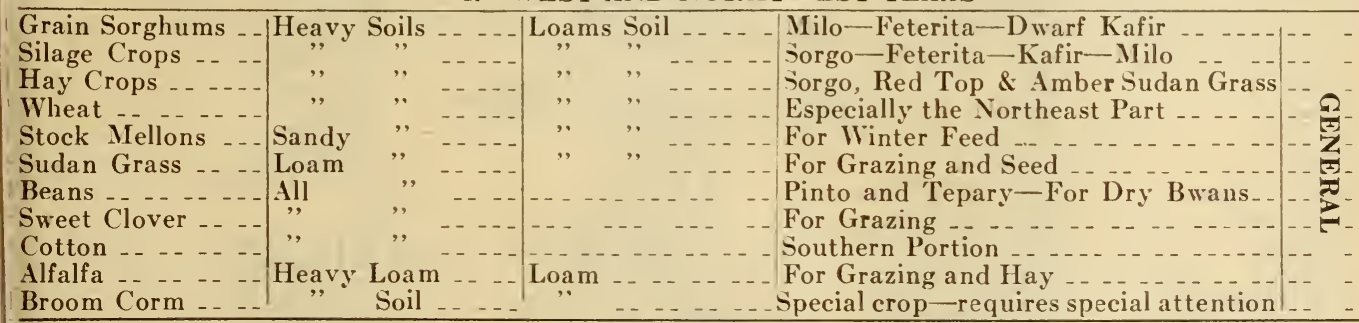

\section{WEST CENTRAL TEXAS.}

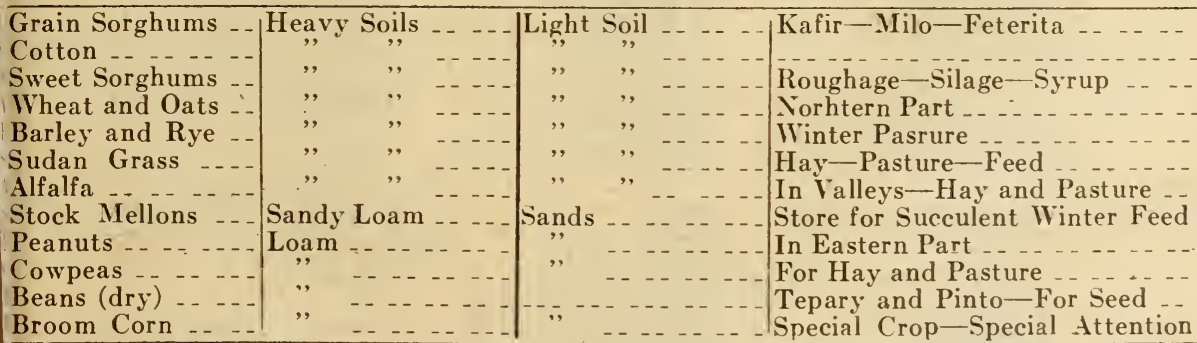

In all sections, loams or sandy loams are preferable for gardens, though some vegetables such as lettuce, cabbage, "greens" and celery do well on black lands. Fruits and berries do best on loams or sandy loams, particularly those with a reddish color.

A proper adaptation of crops to soils and climates will add greatly to farm profits, and the recommendations above are based on wide experience. while there may be some exceptions, the recommendations will be usualy found best.

No attempt has been made to include all crops, and only the principle ones adapted to soils and localities are mentioned. It willusually be found profitable to inoculate clover seeds.

Nothing is said about the variety of seeds or their quality-both these things are highly important, but the purpose here is only to get a better adaptation of crops to soils and climates. 


\section{GENERAL INDEX}

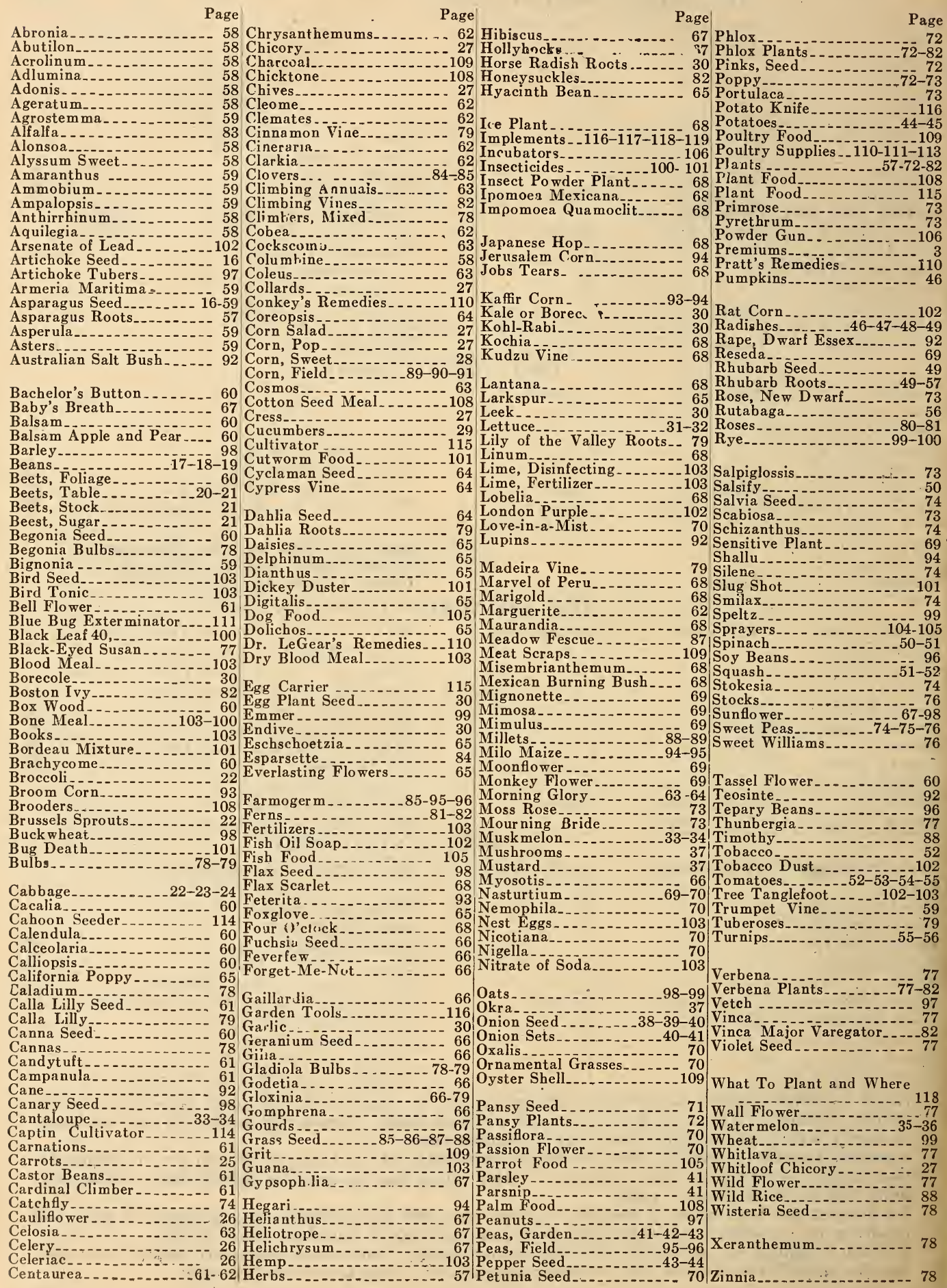




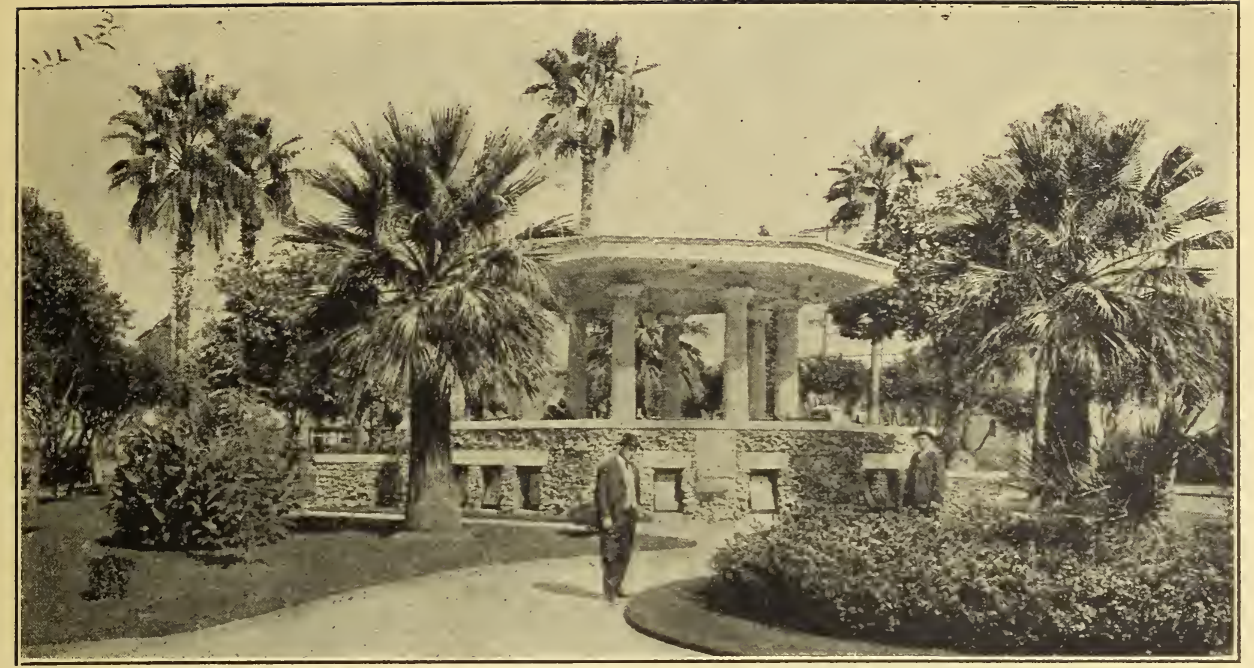

BAND STAND, ALAMO PLAZA, SAN ANTONIO, TEXAS

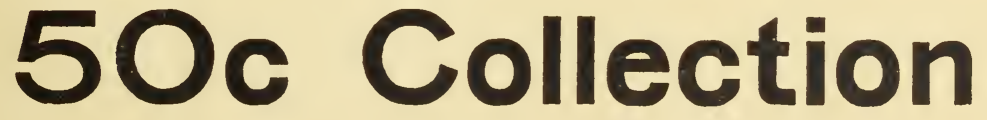

13 Full Sized Packets. 65c worth of First Class Tested Seeds sent post-paid for only 50c.

This collection is made up especially for the front yard or flower garden. We have selected the best varieties and a nice lot of flowers can be raised from these seeds. This is a bargain that you should not overlook. The packets are full size and the seeds fresh and first class.

$\begin{array}{ll}1 & \text { Antirrhinum } \\ 2 & \text { Balsam } \\ 3 & \text { Candytuft } \\ 4 & \text { Cosmos } \\ 5 & \text { Cockscomb }\end{array}$

$\begin{array}{ll}6 & \text { Four O'Clock } \\ 7 & \text { Larkspur } \\ 8 & \text { Mignonette } \\ 9 & \text { Pansy }\end{array}$

10 Poppy

11 Sweet William

12 Sweet Peas

13 Zinnias

This collection is put up in advance and we can ship promptly. No premium is allowed on this collection as it is a premium in itself. 
